\title{
ВІСНИК
}

Бердянського

університету

менеджменту і бізнесу

науковий економічний

журнал

№ 2(46)

2019 


\section{Редакційна колегія:}

Л. І. Антошкіна, д-р екон. наук, професор (головний редактор); Ю. І. Осєнін, д-р техн. наук, професор (заступник головного редактора); Н. В. Рунчева, д-р екон. наук, доцент (відповідальний секретар); В. К. Антошкін, д-р екон. наук, доцент; А. С. Бритвєнко, к-т екон. наук, доцент; О. Л. Горяча, К-т екон. наук, доцент; О. О. Добренко, к-т екон. наук, доцент; М. М. Ігнатенко, д-р екон. наук, доцент; А. Б. Качинський, д-ртехн. наук, професор; Ю. В. Макогон, д-р екон. наук, професор; О. А. Марченко, д-р екон. наук, професор; Н. П. Новак, д-р екон. наук; Г. В. Новицький, д-р юрид. наук, професор; К. А. Пилипенко, д-р екон. наук, доцент; А. В. Руснак, д-р екон. наук, доцент; В. Ф. Столяров, д-р екон. наук, професор; Г. І. Фролова, к-т екон. наук, доцент; Ю. Ю. Юрченко, д-р екон. наук, доцент; З. Глодек, д-р екон. наук, професор; Й. Рогозінська-Мітрут, д-р екон. наук, професор.

Свідоцтво про державну реєстрацію друкованого засобу масової інформації - серія КВ № 13894-2868P

Науковий економічний журнал

«Вісник Бердянського університету менеджменту і бізнесу» внесено до переліку фахових видань України (Наказ МОН України № 1528 від 29 грудня 2014 р.)

Матеріали друкуються украӥнською, російською та англійською мовами

Засновник:

ВНЗ ТОВ «Бердянський університет менеджменту і бізнесу»

Рекомендовано до друку вченою радою

ВНЗ ТОВ «Бердянський університет менеджменту і бізнесу» (протокол № 4 від 27.11.2019 р.)

Відповідальність за достовірність фактів, иитат, власних імен, географічних назв, назв підприємств, організацій, установ та іншої інформації несуть автори статей. Висловлені у цих статтях думки можуть не збігатися з точкою зору редакиійної колегії і не покладають на неї жодних зобов'язань. Переклади і передрук дозволяються лише за згодою автора та редакції.

Журнал заснований у 2008 році.

Виходить двічі на рік.

АДРЕСА РЕДАКЦІї:

Україна, 71118, м. Бердянськ, вул Свободи, 117-А

Тел. 8 (06153) 6-48-54

(c) Бердянський університет менеджменту і бізнесу, 2019 


\section{MICT}

\section{СВІТОВЕ ГОСПОДАРСТВО І МІЖНАРОДНІ ЕКОНОМІЧНІ ВІДНОСИНИ}

Кірова Л. Л.

ПЕРСПЕКТИВИ РОЗВИТКУ СВІТОВОГО СІЛЬСЬКОГОСПОДАРСЬКОГО РИНКУ

В СУЧАСНИХ СВІТОГОСПОДАРСЬКИХ УМОВАХ

Маркіна І. А., Калініченко О. В., Лесюк В. С.

ЕКОНОМІЧНА НЕРІВНІСТЬ: СВІТОВИЙ ДОСВІД ТА ОСОБЛИВОСТІ В УКРАЇНІ 13

\section{ЕКОНОМІКА ТА УПРАВЛІННЯ НАЦІОНАЛЬНИМ ГОСПОДАРСТВОМ}

Мармуль Л. О., Лаврега Г. Р.

ПРІОРИТЕТИ ІНВЕСТИЦІЙНОГО ЗАБЕЗПЕЧЕННЯ СТАЛОГО РОЗВИТКУ

СІЛЬСЬКИХ ТЕРИТОРІЙ

Новак Н. П.

УДОСКОНАЛЕННЯ ІНСТИТУЦІЙНОГО ЗАБЕЗПЕЧЕННЯ ЗАЛУЧЕННЯ

ІНОЗЕМНИХ ІНВЕСТИЦІЙ В ЕКОНОМІКУ УКРАЇНИ

Ортіна Г. В., Лєушина О. А.

ВПЛИВ ДЕРЖАВНОЇ ПОЛІТИКИ НА ІННОВАЦІЙНУ ДІЯЛЬНІСТЬ

СТІЙКОГО ЗБАЛАНСОВАНОГО ЗРОСТАННЯ ЕКОНОМІКИ В УМОВАХ ГЛОБАЛІЗАЦІЇ

Трикоз І. В., Панчук С. С., Полохач Л. П.

ВИЗНАЧЕННЯ ФАКТОРІВ ВПЛИВУ НА ГОТЕЛЬНУ СФЕРУ УКРАЇНИ

ТА ОСОБЛИВОСТІ Й ЗНАЧЕННЯ ІІЇ РИЗИКІВ

\section{ЕКОНОМІКА І УПРАВЛІННЯ ПІДПРИЕМСТВАМИ}

Антошкін В. К., Кузьмін С. В., Усата О. М.

СОЦІАЛЬНО-ЕКОНОМІЧНА БЕЗПЕКА В МЕНЕДЖМЕНТІ СУБ'ЄКТІВ МІКРОРІВНЯ

Біляєв С. C.

ПЕРЕВАГИ ПРОЕКТНОГО ПІДХОДУ НА ПІДПРИЕМСТВІ

Бритвєнко А. С., Запорожець Т. В., Смовж Т. С.

УПРАВЛІННЯ РИЗИКАМИ ЯК ІНСТРУМЕНТ ЕКОНОМІЧНОЇ БЕЗПЕКИ

ОЛІЕ-ЖИРОВИХ ПІДПРИЕМСТВ

Гурбик Ю. Ю., Сальнікова М. В.

ТЕОРЕТИКО-МЕТОДОЛОГІЧНІ ОСНОВИ

АНТИКРИЗОВОГО УПРАВЛІННЯ ПІДПРИЕМСТВОМ

Ігнатенко М. М.

ПРОБЛЕМИ І ПЕРСПЕКТИВИ ВІДТВОРЕННЯ ВИРОБНИЧО-РЕСУРСНОГО ПОТЕНЦІАЛУ

МАЛИХ АГРАРНИХ ПІДПРИЕМСТВ І ДОМОГОСПОДАРСТВ НАСЕЛЕННЯ

Клименко А. А., Гуренко Х. Д., Качковський С. Ю.

ВПЛИВ СТРОКІВ СІВБИ ТА ШИРИНИ МІЖРЯДДЯ НА ВРОЖАЙНІСТЬ СОНЯШНИКУ

Пілявський В. I.

МОДЕЛЮВАННЯ ТРУДОВОГО ПОТЕНЦІАЛУ АГРОПРОМИСЛОВИХ ПІДПРИЕМСТВ

Романюк I. A.

ФОРМУВАННЯ СОЦІАЛЬНОЇ СПРЯМОВАНОСТІ ПІДПРИЕМСТВ

СІЛЬСЬКОГО ЗЕЛЕНОГО ТУРИЗМУ ТА СТРАТЕГІЇ ІІЇ РЕАЛІЗАЦІЇ

Рунчева Н. В., Горяча О. Л., Семенов К. О.

ДЕРЖАВНА ПІДТРИМКА ЕКОНОМІЧНОЇ БЕЗПЕКИ ПІДПРИЕМСТВ АГРАРНОГО СЕКТОРА

Семененко О. Г., Горбатенко О. А.

УДОСКОНАЛЕННЯ ІНСТИТУЦЙНИХ ЗАСАД РОЗВИТКУ ТА ПІДВИЩЕННЯ

КОНКУРЕНТОСПРОМОЖНОСТІ АГРАРНИХ ПІДПРИЄМСТВ

Соловйов Д. І., Голодаєв В. С., Дейнега В. В.

ЗАКЛАДИ ЗДОРОВОГО ХАРЧУВАННЯ ЯК ПЕРСПЕКТИВНИЙ ТРЕНД РОЗВИТКУ

РЕСТОРАННОГО БІЗНЕСУ 
ДЕМОГРАФІЯ, ЕКОНОМІКА ПРАЦІ, СОЦІАЛЬНА ЕКОНОМІКА І ПОЛІТИКА

Антошкіна Л. І., Сквориова О. В.

ДЕМОГРАФІЧНІ ЧИННИКИ ФОРМУВАННЯ ЛЮДСЬКОГО КАПІТАЛУ УКРАЇНИ

Верба Д. В., Верховод І. С.

ДЕРЖАВНІ ОСВІТНІ ВИДАТКИ ТА ДОСТУПНІСТЬ ОСВІТИ

ДЛЯ УКРАЇНСЬКИХ ДОМОГОСПОДАРСТВ

Попова Н. О., Княженко І. І., Кубрак І. С.

СТАТИСТИЧНЕ ВИМІРЮВАННЯ СЕЗОННОСТІ ПРАЦІ У СІЛЬСЬКОМУ ГОСПОДАРСТВІ

РОЗВИТОК ПРОДУКТИВНИХ СИЛ І РЕГІОНАЛЬНА ЕКОНОМІКА

Марченко О. А.

КЛАСТЕРИЗАЦІЯ ЯК ІННОВАЦІЙНА ПЕРЕВАГА У ФУНКЦІОНУВАННІ ТА УПРАВЛІННІ

РЕГІОНАЛЬНОЮ ГАЛУЗЗЮ ТУРИЗМУ

Фролова Г. І., Василатій Д. В., Миргородська Д. О.

СТРАТЕГІЧНЕ ПЛАНУВАННЯ В УПРАВЛІННІ ЕКОНОМІЧНИМ РОЗВИТКОМ РЕГІОНУ

\section{ГРОШІ, ФІНАНСИ І КРЕДИТ}

Малишко В. В.

НАПРЯМИ ТА ІНСТРУМЕНТИ УДОСКОНАЛЕННЯ ФІНАНСОВОЇ ПОЛІТИКИ В УКРАЇНІ

\section{БУХГАЛТЕРСЬКИЙ ОБЛІК, АНАЛІЗ І АУДИТ}

Коваль С. В.

ОРГАНІЗАЦІЯ Й МЕТОДИКА ОБЛІКУ РОЗРАХУНКОВИХ ОПЕРАЦІЙ

АГРАРНИХ ПІДПРИЄМСТВ ТА НАПРЯМИ ЇХ УДОСКОНАЛЕННЯ

Кучеренко С. Ю., Леваєва Л. Ю., Кучеренко М. А.

ОРГАНІЗАЦІЙНО-ОБЛІКОВЕ ЗАБЕЗПЕЧЕННЯ МАЙНА ТА КАПІТАЛІВ

СІЛЬСЬКОГОСПОДАРСЬКИХ ВИРОБНИЧИХ КООПЕРАТИВІВ

АНОТАЦІї 


\section{СОДЕРЖАНИЕ}

\section{МИРОВОЕ ХОЗЯЙСТВО И МЕЖДУНАРОДНЫЕ ЭКОНОМИЧЕСКИЕ ОТНОШЕНИЯ}

Кирова Л. Л.

ПЕРСПЕКТИВЫ РАЗВИТИЯ МИРОВОГО СЕЛЬСЬКОХОЗЯЙСТВЕННОГО РЫНКА

В СОВРЕМЕННЫХ МИРОХОЗЯЙСТВЕННЫХ УСЛОВИЯХ 9

Маркина И. А., Калиниченко А. В., Лесюк В. С.

ЭКОНОМИЧЕСКОЕ НЕРАВЕНСТВО: МИРОВОЙ ОПЫТ И ОСОБЕННОСТИ В УКРАИНЕ 13

\section{ЭКОНОМИКА И УПРАВЛЕНИЕ НАЦИОНАЛЬНЫМ ХОЗЯЙСТВОМ}

Мармуль Л. А., Лаврега Г. Р.

РИОРИТЕТЫ ИНВЕСТИЦИОННОГО ОБЕСПЕЧЕНИЯ УСТОЙЧИВОГО РАЗВИТИЯ СЕЛЬСКИХ

ТЕРРИТОРИЙ

Новак Н. П.

СОВЕРШЕНСТВОВАНИЕ ИНСТИТУЦИОНАЛЬНОГО ОБЕСПЕЧЕНИЯ ПРИВЛЕЧЕНИЯ

ИНОСТРАННЫХ ИНВЕСТИЦИЙ В ЭКОНОМИКУ УКРАИНЫ

Ортина Г. В., Леушина Е. А.

ВЛИЯНИЕ ГОСУДАРСТВЕННОЙ ПОЛИТИКИ НА ИННОВАЦИОННУЮ ДЕЯТЕЛЬНОСТЬ

УСТОЙЧИВОГО СБАЛАНСИРОВАННОГО РОСТА ЭКОНОМИКИ В УСЛОВИЯХ ГЛОБАЛИЗАЦИИ .......226

Трикоз И. В., Панчук С. С., Полохач Л. П.

ОПРЕДЕЛЕНИЕ ФАКТОРОВ ВЛИЯНИЯ НА ГОСТИНИЧНУЮ ОБЛАСТЬ УКРАИНЫ

И ОСОБЕННОСТИ И ЗНАЧЕНИЕ ЕЕ РИСКОВ 32

\section{ЭКОНОМИКА И УПРАВЛЕНИЕ ПРЕДПРИЯТИЯМИ}

Антошкин В. К., Кузьмин Е. В., Усатая Е. Н.

СОЦИАЛЬНО-ЭКОНОМИЧЕСКАЯ БЕЗОПАСНОСТЬ В МЕНЕДЖМЕНТЕ

СУБЪЕКТОВ МИКРОУРОВНЯ 37

Беляев С. С.

ПРЕИМУЩЕСТВА ПРОЕКТНОГО ПОДХОДА НА ПРЕДПРИЯТИИ

Бритвенко А. С., Запорожеи Т. В., Смовж Т. С.

УПРАВЛЕНИЕ РИСКАМИ КАК ИНСТРУМЕНТ ЭКОНОМИЧЕСКОЙ БЕЗОПАСНОСТИ

МАСЛОЖИРОВЫХ ПРЕДПРИЯТИЙ

Гурбик Ю. Ю., Сальникова М. В.

ТЕОРЕТИКО-МЕТОДОЛОГИЧЕСКИЕ ОСНОВЫ

АНТИКРИЗИСНОГО УПРАВЛЕНИЯ ПРЕДПРИЯТИЕМ

Игнатенко Н. $H$.

ПРОБЛЕМЫ И ПЕРСПЕКТИВЫ ВОССОЗДАНИЯ ПРОИЗВОДСТВЕННО-РЕСУРСНОГО

ПОТЕНЦИАЛА МАЛЫХ АГРАРНЫХ ПРЕДПРИЯТИЙ И ДОМОХОЗЯЙСТВ НАСЕЛЕНИЯ

Клименко А. А., Гуренко Х. Д., Качковский С. Ю.

ВЛИЯНИЕ СРОКОВ СЕВА И ШИРИНЫ МЕЖДУРЯДИЙ

НА УРОЖАЙНОСТЬ ПОДСОЛНЕЧНИКА

Пилявский В. И.

МОДЕЛИРОВАНИЕ ТРУДОВОГО ПОТЕНЦИАЛА АГРОПРОМЫШЛЕННОГО ПРЕДПРИЯТИЯ

РоманюК И. А.

ФОРМИРОВАНИЕ СОЦИАЛЬНОЙ НАПРАВЛЕННОСТИ КОМПАНИЙ

СЕЛЬСКОГО ЗЕЛЕНОГО ТУРИЗМА И СТРАТЕГИИ ЕЕ РЕАЛИЗАЦИИ

Рунчева Н. В., Горячая О. Л., Семенов К. А.

ГОСУДАРСТВЕННАЯ ПОДДЕРЖКА ЭКОНОМИЧЕСКОЙ БЕЗОПАСНОСТИ ПРЕДПРИЯТИЙ

АГРАРНОГО СЕКТОРА

Семененко А. Г., Горбатенко А. А.

СОВЕРШЕНСТВОВАНИЕ ИНСТИТУЦИОНАЛЬНЫХ ОСНОВ РАЗВИТИЯ И ПОВЫШЕНИЕ

КОНКУРЕНТОСПОСОБНОСТИ АГРАРНЫХ ПРЕДПРИЯТИЙ 
Соловьев Д. И., Голодаев В. С., Дейнега В. В.

ЗАВЕДЕНИЯ ЗДОРОВОГО ПИТАНИЯ КАК ПЕРСПЕКТИВНЫЙ ТРЕНД

РАЗВИТИЯ РЕСТОРАННОГО БИЗНЕСА

ДЕМОГРАФИЯ, ЭКОНОМИКА ТРУДА, СОЦИАЛЬНАЯ ЭКОНОМИКА И ПОЛИТИКА

Антошкина Л. И., Скворцова О. В.

ДЕМОГРАФИЧЕСКИЕ ФАКТОРЫ ФОРМИРОВАНИЯ ЧЕЛОВЕЧЕСКОГО КАПИТАЛА УКРАИНЫ .....89

Верба Д. В., Верховод И. С.

ГОСУДАРСТВЕННЫЕ РАСХОДЫ НА ОБРАЗОВАНИЕ И ДОСТУПНОСТЬ ОБРАЗОВАНИЯ

ДЛЯ ДОМАШНИХ ХОЗЯЙСТВ УКРАИНЫ

Попова Н. А., Княженко И. И., Кубрак И. С.

СТАТИСТИЧЕСКОЕ ИЗМЕРЕНИЕ СЕЗОННОСТИ ТРУДА В СЕЛЬСКОМ ХОЗЯЙСТВЕ 104

\section{РАЗВИТИЕ ПРОДУКТИВНЫХ СИЛ И РЕГИОНАЛЬНАЯ ЭКОНОМИКА}

Марченко О. А.

КЛАСТЕРИЗАЦИЯ КАК ИННОВАЦИОННОЕ ПРЕИМУЩЕСТВО В ФУНКЦИОНИРОВАНИИ

И УПРАВЛЕНИИ РЕГИОНАЛЬНОЙ ОТРАСЛЬЮ ТУРИЗМА

Фролова Г. И., Василатий Д. В., Миргородская Д. А.

СТРАТЕГИЧЕСКОЕ ПЛАНИРОВАНИЕ В УПРАВЛЕНИИ

ЭКОНОМИЧЕСКИМ РАЗВИТИЕМ РЕГИОНА

\section{ДЕНЬГИ, ФИНАНСЫ И КРЕДИТ}

Малышко В. В.

НАПРАВЛЕНИЯ И ИНСТРУМЕНТЫ СОВЕРШЕНСТВОВАНИЯ

ФИНАНСОВОЙ ПОЛИТИКИ В УКРАИНЕ

\section{БУХГАЛТЕРСКИЙ УЧЕТ, АНАЛИЗ И АУДИТ}

Коваль С. В.

ОРГАНИЗАЦИЯ И МЕТОДИКА УЧЕТА РАСЧЕТНЫХ ОПЕРАЦИЙ

АГРАРНЫХ ПРЕДПРИЯТИЙ И НАПРАВЛЕНИЯ ИХ УСОВЕРШЕНСТВОВАНИЯ

Кучеренко С. Ю., Леваева Л. Ю., Кучеренко М. А.

ОРГАНИЗАЦИОННО-УЧЕТНОЕ ОБЕСПЕЧЕНИЕ ИМУЩЕСТВА И КАПИТАЛОВ

СЕЛЬСКОХОЗЯЙСТВЕННЫХ ПРОИЗВОДСТВЕННЫХ КООПЕРАТИВОВ

АННОТАЦИИ 


\section{CONTENTS}

\section{WORLD ECONOMY AND INTERNATIONAL ECONOMIC RELATIONS}

Kirova L. L.

PROSPECTS OF DEVELOPMENT OF THE WORLD AGRICULTURAL MARKET

IN MODERN WORLD ECONOMIC CONDITIONS

Markina I. A., Kalinichenko O. V., Lesiuk V. S.

ECONOMIC INEQUALITY: WORLD EXPERIENCE AND PECULIARITIES IN UKRAINE 13

\section{NATIONAL ECONOMY AND ITS MANAGEMENT}

Marmul L. O., Lavrega G. R.

PRIORITIES OF INVESTMENT ENSURING SUSTAINABLE DEVELOPMENT OF RURAL AREAS 19

Novak N.P.

IMPROVEMENT OF INSTITUTIONAL SUPPORT FOR ATTRACTING

FOREIGN INVESTMENTS IN THE UKRAINIAN ECONOMY

Ortina H. V., Leushyna O. A.

THE INFLUENCE OF STATE POLICY ON THE INNOVATION ACTIVITY OF SUSTAINABLE

BALANCED ECONOMIC GROWTH IN THE GLOBALIZATION

Trikoz I. V., Panchuk S. S., Polokhach L. P.

INTRODUCTION OF FACTORS INFLUENCE ON UKRAINIAN BUSINESS SPHERE

AND PECULIARITIES OF DETERMINATION OF RISK OF FUNCTIONING

\section{ECONOMY AND MANAGEMENT OF ENTERPRISES}

Antoshkin V. K., Kuzmin Ye. V., Usata O. M.

SOCIO-ECONOMIC SECURITY IN THE MANAGEMENT OF MICRO-LEVEL SUBJECTS

Biliaiev $S$. $S$.

ADVANTAGES OF THE PROJECT APPROACH AT THE ENTERPRISE

Brytvienko A. S., Zaporozhets T. V., Smovzh T.S.

RISK MANAGEMENT AS A TOOL FOR THE ECONOMIC SECURITY

OF OIL AND FAT ENTERPRISES

Hurbyk Y. Y., Salnikova M. V.

THEORETICAL AND METHODOLOGICAL BASIS OF CRISIS MANAGEMENT

OF THE ENTERPRISE

Ihnatenko M. M.

PROBLEMS AND PROSPECTS OF REPRODUCTION OF PRODUCTION AND RESOURCE

POTENTIAL OF SMALL AGRICULTURAL ENTERPRISES AND HOUSEHOLDS

Klimenko A. A., Gurenko H. D., Kachkovsky S. Y.

INFLUENCE OF SOWING TIME AND ROW SPACING ON SUNFLOWER YIELD .61

Piliavskiy V.I.

MODELING OF LABOR POTENTIAL OF AGRO-INDUSTRIAL ENTERPRISES

Romaniuk I. A.

FORMATION OF SOCIAL ORIENTATION OF THE ENTERPRISES OF RURAL

GREEN TOURISM AND STRATEGY OF ITS REALIZATION

Runcheva N. V., Horiacha O. L., Semenov K. O.

STATE SUPPORT TO ECONOMIC SECURITY OF ENTERPRISES OF AGRICULTURAL SECTOR

Semenenko O. G., Gorbatenko O. A.

IMPROVEMENT OF INSTITUTIONAL FRAMEWORK FOR DEVELOPMENT AND INCREASE

OF COMPETITIVENESS OF AGRICULTURAL ENTERPRISES

Solovyov D. I., Golodayev V. S., Deinega V. V.

ESTABLISHMENT OF HEALTHY FOOD AS A PROSPECTIVE TREND OF DEVELOPMENT

OF RESTAURANT BUSINESS 
DEMOGRAPHY, ECONOMY OF LABOUR, SOCIAL ECONOMICS AND POLITICS

Antoshkina L. I., Skvortsova $O$. V.

MAIN TENDENCIES OF NATURAL REPRODUCTION OF THE POPULATION

OF ZAPORIZHIA REGION

Verba D. V., Verkhovod I. S.

BUDGET EXPENDITURES AND EDUCATION AVAILABILITY FOR UKRAINIAN HOUSEHOLDS

Popova N. O., Kniazhenko Y. Y., Kubrak Y. S.

A STATISTICAL MEASUREMENT OF THE SEASONALITY OF LABOR IN AGRICULTURE

\section{PRODUCT DEVELOPMENT AND REGIONAL ECONOMY}

Marchenko O. A.

CLUSTERING AS AN INNOVATIVE ADVANTAGE IN FUNCTIONING

AND MANAGING THE REGIONAL INDUSTRY OF TOURISM

Frolova G. I., Vasilatiy D. V., Mirgorodskaya D. O.

STRATEGIC PLANNING IN MANAGEMENT ECONOMIC DEVELOPMENT OF THE REGION 116

\section{CURRENCY, FINANCE AND CREDIT}

Malyshko V. V.

DIRECTIONS AND TOOLS FOR IMPROVING THE FINANCIAL POLICY IN UKRAINE

\section{ACCOUNTING, ANALYSIS AND AUDIT}

Koval S. $V$.

ORGANIZATION AND METHODOLOGY OF ACCOUNTING OF SETTLEMENT OPERATIONS OF AGRICULTURAL ENTERPRISES AND DIRECTIONS OF THEIR IMPROVEMENT

Kucherenko S. Yu., Levayeva L. Yu., Kucherenko M. A.

ORGANIZATIONAL AND ACCOUNTING SUPPORT OF PROPERTY AND CAPITALS

OF AGRICULTURAL PRODUCTION COOPERATIVES 


\title{
СВІТОВЕ ГОСПОДАРСТВО \\ I МІЖНАРОДНІ ЕКОНОМІЧНІ ВІДНОСИНИ
}

УДК 339.9

Л. Л. Кірова

\section{ПЕРСПЕКТИВИ РОЗВИТКУ СВІТОВОГО СІЛЬСЬКОГОСПОДАРСЬКОГО РИНКУ В СУЧАСНИХ СВІТОГОСПОДАРСЬКИХ УМОВАХ}

\begin{abstract}
Анотація. Розглянуто та досліджено роль світового сільськогосподарського ринку до викликів глобалізації, його можливостей та перспектив.

Ключові слова: сільськогосподарська сировина, агропромислові кластери, агропродовольчий сектор, аграрна сировина, спеціалізація, продовольство, конкурентоспроможність.
\end{abstract}

Summary. Consider and explore the role of the global agricultural market in challenging globalization, its capabilities and prospects.

Key words: agricultural raw materials, agro-industrial clusters, agro-food sector, agrarian raw material, specialization, food, competitiveness.

$$
\text { DOI : } 10.33783 / 1977-4167-2019-46-2-9-12
$$

Постановка проблеми. Сільське господарство має ряд особливостей, які відрізняють його від інших економічних секторів. Вирощування аграрної продукції здійснюється передусім як приватна діяльність, яка виконується на обмеженій території переважно домашніми господарствами, але також має багато можливостей для колективних дій. На економічний стан цього сектору суттєво впливають глобальні сили, а його структура і розвиток багато в чому залежать від державного втручання.

Аналіз останніх досліджень і публікацій. У вітчизняній науковій літературі питання, пов'язані з процесами світового сільськогосподарського ринку, сільськогосподарських кластерів та інших бізнесових мереж у сучасних умовах глобалізації, знайшли відображення в працях: О. Богми, М. Войнаренко, Д. Крісанова, А. Мокія, С. Мочерного, Ю. Пахомова, В. Савченка, Г. Семенова, С. Соколенка, В. Чужикова та ін. Цій проблематиці присвячено також дослідження багатьох авторів близького та далекого зарубіжжя, зокрема: Т. Адебойе, К. Надві, М. Пиоре, М. Портера, В. Прайса, К. Сєйбела, В. Третяка, П. Хазеля, Г. Хасаєва та ін.

Мета статті - розглянути, дослідити та зробити аналіз розвитку світового сільськогосподарського ринку, його можливостей та перспективи розвитку.
Виклад основного матеріалу дослідження. Чільне місце в системі світового сільськогосподарського ринку посідає міжнародна торгівля аграрною продукцією та продовольством, у той же час як останні елементи інколи мають протилежно спрямований вплив на світовий сільськогосподарський ринок. Так, розширення діяльності ТНК, трансфери капіталу, технологій та інтернаціоналізація знань - усе це у поєднанні з діяльністю міжнародних організацій скерований на лібералізацію економічних стосунків і міжнародної торгівлі на глобальних аграрних ринках. Зі свого боку аграрна та торговельна політика держави, а в деяких випадках, і міжнаціональні угоди можуть утворювати захисні бар'єри для підтримання національних виробників, або для уникнення посилення конкуренції з боку аграрних виробників держав, які не входять у дані міжнаціональні формування й угоди [1].

Найбільш уразливими 3 точки зору продовольчої безпеки є регіони Близького Сходу, Африки, Азії та Європи, рівень самозабезпеченості в яких недостатній, про що свідчать дані табл. 1.

Сьогодні в багатьох країнах агропродовольчі системи стали більш складними, починаючи 3 використання фірмами біотехнологій і завершуючи високим ступенем перероблення продуктів харчування. Дедалі частіше ці компанії розробляють різні альянси з іншими учасниками системи, утворюючи нові агропродовольчі формування продовольчі кластери.

(C) Л. Л. Кірова, 2019

Бібліографія ДСТУ 8302:2015:

Кірова Л. Л. Перспективи розвитку світового сільськогосподарського ринку в сучасних світогосподарських умовах. Вісник Бердянського університету менеджменту і бізнесу. 2019. № 2 (46). С. 9-12.

References (APA):

Kirova, L. L. (2019). Perspektyvy rozvytku svitovoho silskohospodarskoho rynku v suchasnykh svitohospodarskykh umovakh [Prospects for the development of the world agricultural market in modern world economic conditions]. Visnyk Berdianskoho universytetu menedzhmentu i biznesu, 2 (46), 9-12 (in Ukr.). 


\begin{tabular}{l}
\hline \multicolumn{3}{|c|}{$\begin{array}{c}\text { Таблиця } 1 \\
\text { Сальдо міжнародної торгівлі продовольством } \\
\text { за регіонами світу у } 2017 \text { р., млрд дол. США }\end{array}$} \\
\begin{tabular}{|l|c|c|}
\hline \multicolumn{1}{|c|}{ Регіони } & $\begin{array}{c}\text { Позитивне } \\
\text { сальдо }\end{array}$ & $\begin{array}{c}\text { Негативне } \\
\text { сальдо }\end{array}$ \\
\hline $\begin{array}{l}\text { Центральна і Південна } \\
\text { Америка }\end{array}$ & +91 & - \\
\hline СШАі Канада & +35 & - \\
\hline $\begin{array}{l}\text { Австралія і Нова } \\
\text { Зеландія }\end{array}$ & +15 & -7 \\
\hline $\begin{array}{l}\text { Країни колишнього } \\
\text { СРСР }\end{array}$ & - & -21 \\
\hline $\begin{array}{l}\text { Центральна і Південна } \\
\text { Африка }\end{array}$ & - & -22 \\
\hline Европейський Союз & - & -41 \\
\hline Близький Схід & & -50 \\
\hline Південно-Східна Азія & & - \\
\hline
\end{tabular}
\end{tabular}

Оскільки сільське господарство стає дедалі більш концентрованим і інтегрованим, ці гігантські кластери створюють олігопсонію, тобто ринок, на якому невелика кількість покупців має ринкову владу над великою кількістю продавців для більшої частини агропродовольчого ланцюжка, дозволяючи їм максимізувати прибуток за мінімального ризику. В результаті агропродовольча система стала схожа на пісочний годинник. Унизу знаходяться мільйони фермерів і найманих сільськогосподарських працівників, у той час як у верхній частині - мільярди споживачів як багатих, так і бідних. У вузькому місці в центрі перебувають декілька транснаціональних корпорацій - постачальників сировини, харчової промисловості та роздрібної торгівлі - отримуючи прибуток від кожної угоди. Як правило, ці фірми закуповують сільгоспсировину через закриті контракти або внутрішньофірмові постачання за внутрішніми цінами, а не на відкритих оптових ринках [2] і навіть тоді, коли вони купують їх на оптових ринках, ціни можуть бути значно нижче витрат на виробництво у зв'язку з надмірною пропозицією [2]. Отже, збитки від «стиснення» витратами цін припадають на виробників, які несуть велику частину ризику і малу частку нагороди, якщо така є взагалі.

Оскільки сільське господарство залежить від торгівлі значною мірою, ніж більшість економічних секторів, великий вплив на його стан мають умови, що визначають середовище торгівлі та торговельна політика. У той час як загальні торгові бар'єри в промислово розвинених країнах значно знизилися за останні десять років, «залишок» бар'єрів зосереджено на сировинній продукції сільського господарства та продукції трудомістких виробництв, відносно яких країни менш розвинені, володіють порівняльними перевагами у міжнародній конкуренції. Високий рівень підтримки сільського господарства, що в середньому сягає 280 млрд дол. США на рік у країнах, що входять до ОЕСР, тиснуть на світові ціни на низку ключових товарів (зокрема, цукор, бавовну, молоко та яловичину) і глибоко підривають зростання сільського господарства в країнах, що розвиваються [3]. Квоти і тарифи в країнах-членах ОЕСР залишаються важливим інструментом для захисту внутрішніх ринків; також санітарні та фіто-санітарні обмеження дедалі більше виконують ті самі функції. Ставки тарифів і квоти дотепер захищають $28 \%$ сільськогосподарської продукції ОЕСР [3]. Хоча середній тариф на сільськогосподарську продукцію в цих країнах знаходиться в розбіжності 10-20\%, дуже високі тарифи (до $500 \%$ ) по конкретних позиціях імпорту сільськогосподарської продукції знижують ринкові можливості для фермерів країн, що розвиваються [4].

Нарощування сільськогосподарського виробництва більше не $є$ пріоритетною метою для Європейського Союзу. Замість цього на перший план виходять такі питання:

- підвищення рентабельності сільськогосподарського виробництва;

- розвиток нових перспективних напрямів сільського господарства та перероблення сільгоспсировини (наприклад, органічного виробництва, тобто вирощування і перероблення аграрної продукції з метою отримання екологічно чистого та безпечного продовольства);

- оптимальне використання природних ресурсів, захист і поліпшення навколишнього середовища.

Стосовно підтримки аграріїв парадигма САП також змінилася: якщо в перші десятиліття іiі функціонування вона була покликана гарантувати стабільні доходи фермерів, то тепер акцент робиться на поліпшення якості життя сільського населення та на комплексний розвиток сільської місцевості. На реалізацію цих нових цілей були спрямовані системні реформи САП, що проводилися 3 початку 1990-х років: План Макшерpi (MacSharry Plan) та «Порядок денний-2000» («Agenda-2000»), які привели до формування двох взаємопов'язаних, але окремих напрямів САП, так званих «опор» (pillars) [5].

Перший напрям (підтримка виробництва) спрямовано на вирішення питань організації сільськогосподарських ринків і підтримки фермерських доходів. Ця «опора» використовує переважно спільні (наднаціональні) заходи регулювання внутрішніх ринків та сільгоспвиробництва, переважно за допомогою системи загальної орга-

${ }^{1}$ Джерело: WTO: International Trade Statistics 2017. - Geneva: World Trade Organization, 2017. - [Електронний ресурс]. - Режим доступу: http://www.wto.org/ english/res_e/statis_e/its2010_e/its2010_e.pdf. 
нізації ринків (наразі в $\mathrm{CC}$ діє 21 організований ринок, у тому числі: зерна, свинини, яловичини, м'яса птиці й яєць, молочних продуктів, фруктів i овочів, вина, цукру та ін.). Для деяких товарів (наприклад, бавовни) діють спеціальні режими підтримки виробників. За межами цієї системи залишена лише невелика частина продукції аграрного сектору (наприклад, мед, кава, конина, шовкопряди), проте частково САП охоплюе і цю продукцію. Наприклад, з бюджету $Є C$ виділяють кошти на боротьбу з хворобами бджіл і на просування меду на внутрішньому ринку Союзу; 3 коштів Євросоюзу також фінансуються заходи законодавчого захисту товарних марок кави з підтвердженим географічним походженням з $\mathrm{CC}$.

Порівняно з першими етапами САП помітно зросло значення інструментів безпосереднього (неринкового) впливу на аграрний сектор. Зниження інтервенційних цін $\Theta C$ під тиском вимог СОТ, зростання внутрішнього попиту, здешевлення імпорту через зменшення світових цін (до 2017 р.), а також підвищення курсу євро - усе це різко знизило ефективність і значення втручання $€ C$ на більшості організованих ринків. Витрати на ці заходи в 20102017 pр. становили $10 \%$ від загального бюджету першого напряму САП. Також знизилося значення експортних субсидій (тепер на них припадає менше $9 \%$ загальних витрат у цій «опорі»). Водночас помітно (майже до $80 \%$ ) зросли витрати на прямі субсидії, пов'язані з виробництвом конкретних продуктів i зі скороченням оброблюваних площ [6]. До 2017 p. прямі платежі становитимуть $91 \%$ витрат у рамках першого напряму, і будуть здійснюватися переважно у вигляді єдиних аграрних платежів. Причому повна виплата цих субсидій буде здійснюватися на умовах взаємної відповідності (тобто лише за дотримання фермерами екологічних норм і стандартів якості). Це дозволить скоротити забруднення навколишнього середовища, зменшити площу оброблюваних земель, а також зайняти частину орних земель (до $15 \%$ до 2020 р.) культурами для виробництва біопалива.

Другий напрям САП (соціально-структурний) покликаний підтримувати збалансований розвиток сільських територій, сприяти підвищенню рівня життя на селі, а також зменшення соціально-економічних диспропорцій між сільськими місцевостями країн і регіонів $\mathrm{CC}$.

«Друга опора» формується за рахунок трьох основних «осей», тобто напрямів, які забезпечують цільову концентрацію заходів сільського розвитку. Перша «вісь» стосується підвищення конкурентоспроможності аграрного сектору. Вона включає широкий комплекс заходів, спрямованих на розвиток людського капіталу, у їх числі: професійна підготовка фермерів, допомога сільській молоді зі започаткуванням бізнесу, в тому числі не тільки пов'язаним з сільським виробни- цтвом, дострокові пенсії для літніх фермерів, інформаційно-консультаційні послуги. До першої «осі» також належать різноманітні заходи, націлені на модернізацію виробництва і розвиток сільських територій. Європейський Союз здійснюе допомогу фермерам в освоєнні виробництва нових видів продукції, реорганізації господарства, впровадження нових технологій виробництва i перероблення сільгосппродукції. Крім того, зростаюча увага приділяється розвитку сільської інфраструктури. Дедалі більше значення в рамках цієї «осі» надається також підвищенню якості та безпеки продуктів харчування, для чого вводяться спеціальні стандарти і сертифікати.

Друга «вісь» - поліпшення навколишнього середовища та сільських ландшафтів, шляхом виплати компенсацій фермерам у незручних гірських регіонах, особливих агроекологічних платежів (від 200 до 900 євро на га), платежів за поліпшення умов утримання тварин (50 євро на голову), субсидування заліснення сільськогосподарських земель та ін.

Третя «вісь» націлена на поліпшення якості життя і диверсифікацію господарської діяльності на сільських територіях. Вона включає зокрема такі заходи: покращення доступу селян до основних послуг; благоустрій та оновлення житлового фонду сіл; охорона культурної спадщини, розвиток несільськогосподарських видів зайнятості; заохочення туризму в сільських районах; сприяння розвитку малого бізнесу. До цієї осі примикає програма «LEADER» 3 підтримки розробляння локальних стратегій розвитку сільських регіонів, створення ініціативних груп з реалізації та впровадження інновацій тощо.

У рамках другого напряму САП країнам встановлені мінімальні норми витрат по кожній «осі»: $25 \%$ - для другої «осі», по $10 \%$ - для першої і третьої, $5 \%$ - для програми «LEADER». У середньому по ЄС на заходи другої «осі» до 2018 р. буде направлено $46 \%$ усіх витрат другої «опори» САП. Фактична структура витрат, як і взагалі заходи політики другої «опори» САП, конкретизується в національних Програмах розвитку сільських територій. Національні програми розробляються на основі загальних напрямів аграрного розвитку $\mathrm{EC}$ і реалізуються на принципах сумісного фінансування. Наприклад, витрати, що заплановано на період 2012-2018 р. по національній програмі Німеччини становлять 13 млрд євро, з них $60 \%-$ асигнування з бюджету $\mathrm{CC}$, а $40 \%$ - 3 національних та місцевих бюджетів. В Ірландії із засобів $\mathrm{EC}$ буде покрито понад $50 \%$ витрат національної програми, в Польщі та Литві - майже 80 \% [7].

У 2017 р. спеціальна група 3 реформування САП, яка створена Європейською Комісією, представила свої пропозиції у вигляді пакета нормативних актів, які мають вступити в дію після 
2018 р. [7]. Заявлена мета цієї реформи полягає в забезпеченні європейських громадян безпечними і якісними продуктами харчування, зберігаючи при цьому навколишнє середовище [7].

Відповідно до цих пропозицій трьома загальними цілями майбутньої САП є: вання;

- життєздатне виробництво продуктів харчу-

- стале управління природними ресурсами; торій

- збалансований розвиток сільських тери-

Остання мета кореспондується з цілями регіональної політики СС, що фінансується Структурним фондом, у тому числі із заходами щодо створення життєздатних кластерів.

Висновки. Отже, економічним стрижнем пропозицій стосовно реформування спільної аграрної політики ЕС є суттєве скорочення заходів підтримки аграрного сектору, що належать до так званої «жовтої скриньки». Це буде складно, оскільки відмова від експортних субсидій і ослаблення або скасування заходів внутрішньої підтримки зажадають докорінної зміни всієї «архітектури» САП, а також забезпечення більшої відкритості європейських ринків аграрної продукції та продовольства. Реалізація цих заходів поставить європейських фермерів перед вибором, чи забезпечити життєздатність власним господарствам в умовах посилення конкуренції, чи вийти з ринку. Одночасно ці реформаторські заходи створять стимули для експортної експансії на ринки ЄС сільгоспвиробників з інших країн, які мають або будуть здатні створити відчутні конкурентні переваги.

\section{Література}

1. Жаліло Я. А., Собкевич О. В., Русан В. М., Юрченко А. Д., Клименко І. В., Скороход В. О., Ус I. В. Ризики світової продовольчої кризи та виклики для України. Аналітична записка. К. : НІСД, 2011. $11 \mathrm{c.}$

2. Саблук П. Т., Білорус О. Г., Власов В. І. Глобалізація і продовольство : монографія. К. : ННЦ IAE, 2008. C. 145-148.

3. ООН: Щороку Земля втрачає 30 мільйонів гектарів сільськогосподарських угідь. URL : http://www.newsmarket.com. ua/2010/10/10022592/shhoroku-zemlya-vtrachaye30-milyoniv-gektar.

4. Finance.ua. Тренд - крупные инвесторы переключаются на сельское хозяйство. - 06.06.2008. URL : https://news.finance.ua/ru/news/-/128995/ trend-krupnye-investory-pereklyuchayutsya-naselskoe-hozyajstvo.

5. OECD - FAO Agricultural Outlook 20082017. - Brussels: OECD/FAO, 2008. 73 p.

6. Von Braun, J. The World Food Situation: New Driving Forces and Required Actions. Washington DC : IFPRI, 2007. 107 p.

7. World Agriculture: Towards 2015/2030 - An FAO Perspective. Rome : FAO, 2003. 176 p.

\section{References}

1. Zhalilo Ia. A., Sobkevych O. V., Rusan V. M. Yurchenko A. D., Klymenko I. V., Skorokhod V. O., Us I. V. (2011). Ryzyky svitovoi prodovolchoi kryzy ta vyklyky dlia Ukrainy. Analitychna zapyska [Risks of the global food crisis and challenges for Ukraine. Analytical note]. Kyiv, NISD Publ, $11 \mathrm{p}$.

2. Sabluk P. T., Bilorus O. H., Vlasov V. I. (2008) Globalizaciya i prodovolstvo [Globalization and food]. Kyiv, NNC IAE Publ., P. 145-148.

3. OON_Schoroku Zemlya vtrachae 30 milioniv gektariv silsk̄ogospodarskih ugid [UN: The Earth loses 30 million hectares of agricultural land each year]. Retrieved from http://www.newsmarket. com.ua/2010/10/10022592/shhoroku_zemlya_ vtrachaye_30_milyoniv_gektar.

4. Finance.ua (2008). Trend - krupnie investori pereklyuchayutsya na selskoe hozyaistvo [Trend - large investors are switching to agriculture]. Retrieved from https://news.finance.ua/ru/news/-/128995/trendkrupnye-investory-pereklyuchayutsya-na-selskoehozyajstvo.

5. OECD - FAO Agricultural Outlook 20082017. Brussels_OECD/FAO_2008. 73 p.

6. Von Braun_J. The World Food Situation_New Driving Forces and Required Actions. Washington DC_IFPRI_2007. 107 p.

7. World Agriculture_Towards 2015/2030 - An FAO Perspective. Rome_FAO_2003. 176 p. 


\title{
I. А. Маркіна, \\ О. В. Калініченко, \\ B. С. Лесюк
}

\section{ЕКОНОМІЧНА НЕРІВНІСТЬ: СВІТОВИЙ ДОСВІД ТА ОСОБЛИВОСТІ В УКРАЇНІ}

\begin{abstract}
Анотація. Статтю присвячено дослідженню сутності й особливостям економічної нерівності в Україні та світі. Досліджено економічну нерівність в Україні за допомогою таких методів, як: крива Лоренца, коефіиієнт Джині та квінтильний коефіцієнт. Розглянуто динаміку прожиткового мінімуму, номінальної та реальної заробітної плати в Україні. Проаналізовано рівень життя та середньомісячну заробітну плату в Україні та Свропі. Визначено основні напрями реформування соціальної політики України для забезпечення сталого соціального розвитку. Визначені основні заходи подолання економічної нерівності в Україні.

Ключові слова: економічна нерівність, рівень життя, заробітна плата, крива Лоренца, коефіцієнт Джині, квінтильний коефіцієнт.

Summary. The article is devoted to the study of the nature and characteristics of economic inequality in Ukraine and the world. Economic inequality in Ukraine was studied using the Lorenz curve, Gini coefficient and income quintile ratio. The dynamics of living wage, nominal and real wages in Ukraine are considered. The standard of living and average monthly wages in Ukraine and Europe are analyzed. The main directions of reforming the social policy of Ukraine to ensure sustainable social development are identified. The main measures to overcome economic inequality in Ukraine are identified.
\end{abstract}

Key words: economic inequality, standard of living, salary, Lorenz curve, Gini coefficient, income quintile ratio.

$$
\text { DOI : 10.33783/1977-4167-2019-46-2-13-18 }
$$

Постановка проблеми. Найбільшою і найсуперечливішою проблемою, що характерна не лише для України, а й для всього світу, є економічна нерівність, яка супроводжує людство протягом усього його існування. Вона негативно позначається на рівні життя населення, впливає на людський розвиток, є джерелом соціальної напруженості та державної нестабільності, негативно впливає на розвиток національної економіки. Разом з тим, з іншого боку, вона є рушійною силою економічної активності населення. Головною проблемою економічної нерівності $є$ бідність, яка своєю чергою призводить до погіршення здоров'я населення, зниження працездатності, негативно впливає на соціально-економічний розвиток. Нині питання економічної нерівності постає доволі гостро, адже для структури українського суспільства характерні: низька частка середнього класу, значна диференціація доходів населення, велика частка бідного населення.

Аналіз останніх досліджень і публікацій. Дослідженню питань економічної нерівності населення присвячені роботи таких науковців, як: І. В. Аксьонова [8], О. М. Балакірєва [9], В. О. Бригадир [6], О. В. Бондар-Підгурської [15], О. Больша [14],
Н. В. Коваль [3], В. Никифоренко [16] та ін. Авторами визначено основні макроекономічні та соціальні чинники, які мають найбільший вплив на нерівність у розподілі доходів домогосподарств.

Мета статті - розкрити сутність економічної нерівності у світі, іiї особливостей в Україні та розробити пропозиції з удосконалення заходів подолання економічної нерівності.

Виклад основного матеріалу дослідження. Найбільшою із соціальних проблем, що постала перед сучасним суспільством, $є$ економічна нерівність, яка належить до соціальної нерівності та є однією з найбільш досліджуваних її форм. Вона породжує відмінності у розподілі економічних активів та доходів між групами населення або окремими особами.

Поступове зростання економічної нерівності, зокрема бідності, як іiї прояву, у великої кількості країн зумовлює багато питань щодо впливу глобалізації на національну економіку та міжнародне суспільство загалом.

Економічна нерівність на сьогодні є надзвичайно великою на світовому рівні і має тенденцію до зростання. Понад $70 \%$ загального світового багатства знаходяться у володінні $10 \%$ населення.

(C) I. А. Маркіна, О. В. Калініченко,В. С. Лесюк, 2019

Бібліографія ДСТУ 8302:2015:

Маркіна І. А., Калініченко О. В., Лесюк В. С. Економічна нерівність: світовий досвід та особливості в Україні. Вісник Бердянського університету менеджменту і бізнесу. 2019. № 2 (46). С. 13-18.

References (APA):

Markina, I. A., Kalinichenko, O. V., Lesiuk, V. S. (2019). Ekonomichna nerivnist: svitovyi dosvid ta osoblyvosti v Ukraini [Economic inequality: world experience and peculiarities in Ukraine]. Visnyk Berdianskoho universytetu menedzhmentu $i$ biznesu, 2 (46), 13-18 (in Ukr.). 
У глобальному вимірі в 2017 р. 1 \% людей, що перебувають зверху в розподілі багатства, володіли $33 \%$ загальних статків проти $28 \%$ у 1980 р. У цей час $50 \%$ населення, що знаходяться у нижній частині цього розподілу, володіє менше ніж 2 \% глобального багатства [1, с. 200].

За даними Європейської економічної комісії Організації Об'єднаних Націй, найбільша середньомісячна заробітна плата в Європі становить 7351 дол. США у Швейцаріі. Тим часом найгірший показник в Україні, де середньомісячна заробітна плата за аналізований період становить
267 дол. США, що в 27,5 рази менше за показник Швейцарії. За рівнем зарплат Україна знаходиться на останньому місці в Свропі. Якщо порівнювати українську середньомісячну заробітну плату з країнами Свропейського Союзу, то найближче до нашого показника розташувалась сусідня Румунія з результатом 819 дол. США, а от найбільша середньомісячна заробітна плата в СС в Люксембурзі й становить 5988 дол. США, що в 22,4 рази більше ніж в Україні та в 7,3 рази ніж в Румунії (рис. 1).

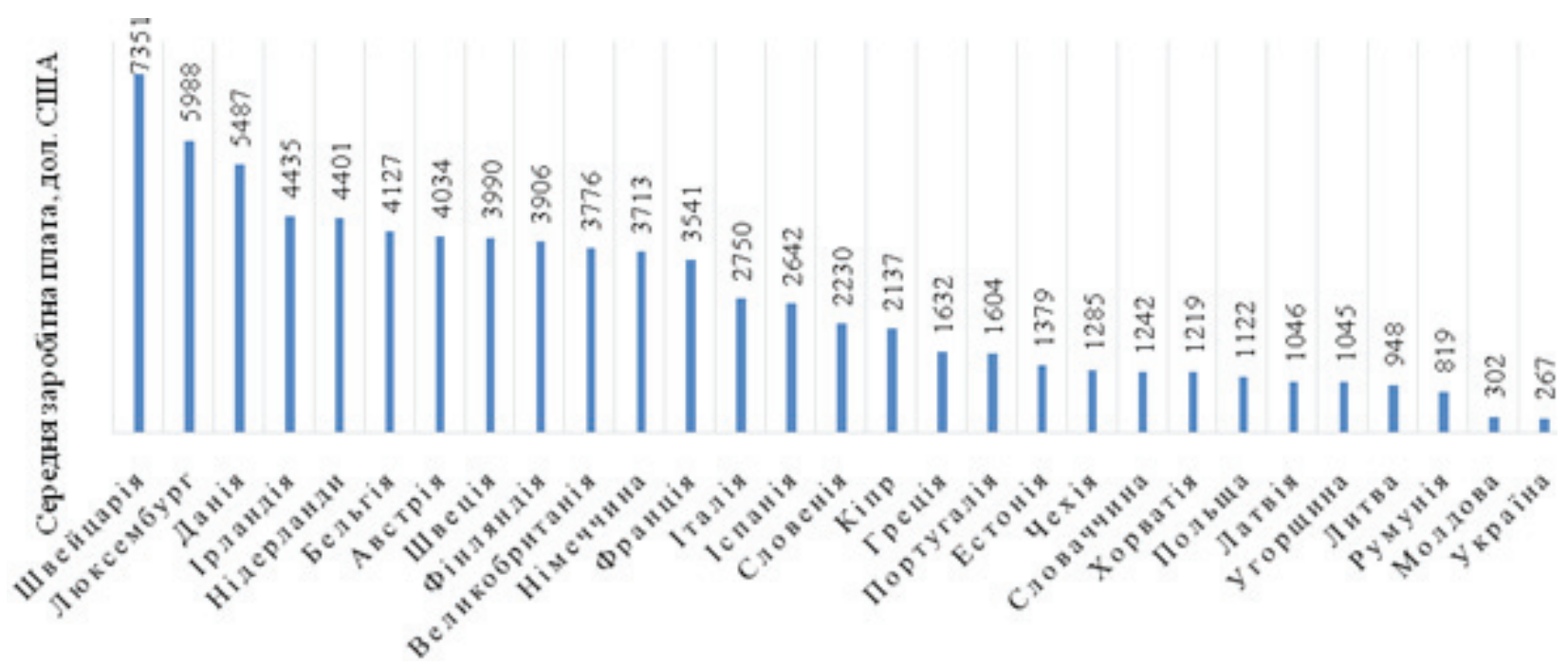

Рис. 1. Середньомісячна заробітна плата в окремих країнах Свропи та України, 2017 р. (розраховано авторами за даними [2])

У сучасній Україні спостерігається своєрідний феномен: офіційна статистика свідчить про доволі помірний, відповідний європейським стандартам ступінь нерівності, а населення і експерти переконані в тому, що суспільство $є$ дуже розшарованим [3, с. 47].

Нерівномірність розподілу доходів можна визначити за допомогою великої кількості різних методів, серед яких у дослідженні використали криву Лоренца (розподіл доходів в економіці), проаналізували коефіцієнт Джині (коефіцієнт концентрації доходів) та розглянули квінтильний коефіцієнт (диференціація доходів населення).
Доходи населення України мають широку нерівномірну основу, яка намагається вирівнятися під бісектрису, адже що менше фактична крива Лоренца відхиляється від неї, то меншим є ступінь нерівності в розподілі доходів. У нашому випадку можна стверджувати про помірну нерівність у загальних доходах домогосподарств, які вони вважають достатніми, щоб не відчувати себе бідними за розміром середньодушового грошового доходу (рис. 2).

По мірі руху кривої Лоренца, починаючи від найбідніших верств населення, відбувається плавний перехід до людей із середнім достатком. Про-

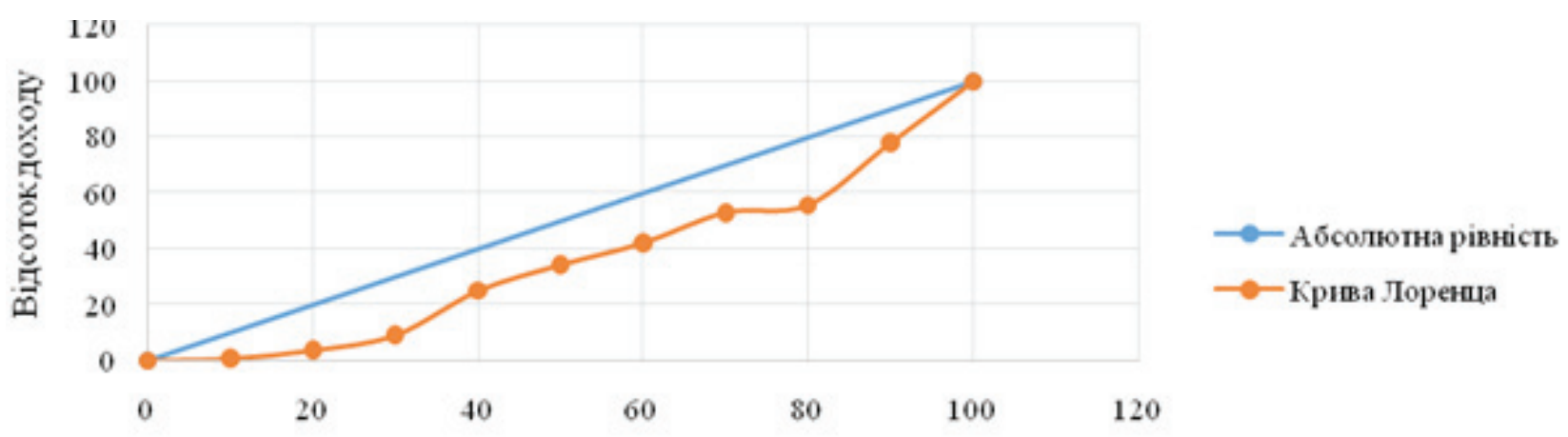

Відсотокдомашніх господарств

Рис. 2. Крива Лорениа для України, 2017 р. (розраховано авторами за даними [4]) 
те ближче до кінця, крива Лоренца робить різкий стрибок, що свідчить про наявність суттєвого розриву між багатим та середнім класом. Варто зазначити, що саме середній клас формує споживчий потенціал національної економіки країни та $€$ своєрідним стандартом стабільності суспільства, визначаючи кінцевий попит, адже середній клас $€$ символом соціальної держави. Велика розлогість кривої у випадку з бідною частиною населення та різкий перехід до багатих підтверджує наявну економічну нерівність серед населення України.

Показовим є також розрахунок коефіцієнта Джині. За офіційними даними Державної служби статистики України він має тенденцію до спаду, оскільки у 2017 р. порівняно з 2013 р. відбулося його зменшення на 0,005 , а у 2017 p. порівняно 3 2016 р. - на 0,012 (табл. 1).

Проведене Державною службою статистики України дослідження не є актуальним, причиною цього є висока тінізація національної економіки та приховування заможними людьми своїх справжніх доходів, що ставить під сумнів точність статистичних даних.

За результатами розрахунків визначено квінтильний коефіцієнт, а саме: за даними Державної служби статистики України, наявна різниця між

Таблиия 1

Динаміка індексу Джині для України, 2013-2017 рр. (розраховано авторами за даними [4])

\begin{tabular}{|c|c|c|c|c|c|c|c|c|c|}
\hline & \multicolumn{4}{|c|}{ Роки } & \multicolumn{2}{|c|}{2017 р. до 2013 р. } & \multicolumn{2}{|c|}{2017 р. до 2016 p. } \\
\cline { 2 - 9 } & 2013 & 2014 & 2015 & 2016 & 2017 & $\begin{array}{c}\text { абсолютне } \\
\text { відхилення, } \\
(+,-)\end{array}$ & $\begin{array}{c}\text { відносне від- } \\
\text { хилення, } \\
(\%)\end{array}$ & $\begin{array}{c}\text { абсолютне } \\
\text { відхилення } \\
(+,-)\end{array}$ & $\begin{array}{c}\text { відносне } \\
\text { відхилення, } \\
(\%)\end{array}$ \\
\hline $\begin{array}{c}\text { Індекс } \\
\text { Джині }\end{array}$ & 0,237 & 0,226 & 0,227 & 0,220 & 0,232 & 0,005 & 2,1 & 0,012 & 5,4 \\
\hline
\end{tabular}

20 \% найбагатших і 20 \% найбідніших становить 3 рази.

За даними «Індексу людського розвитку» Програми розвитку ООН, що базується на інформації звітів національних статистичних органів, індекс Джині та квінтильний коефіцієнт в Україні $€$ найнижчими у світі [5, с. 31].

Показово зазначають експерти, що незважаючи на оптимістичні показники Державної служби статистики, соціальна нерівність в Україні все ж є однією з найбільших у світі. За твердженням директора соціальних програм Центру Разумкова, Л. Шангіної коефіцієнт Джині для України коливається від 0,3 до 0,6 [6, с. 14]. Водночас різниця в доходах між $10 \%$ найбагатших і $10 \%$ найбідніших з урахуванням тіньових доходів досягає 40 разів [7, c. 11].

Наведені показники знову ставлять під сумнів точність статистичних даних, які надає Державна служба статистики, адже вони не відображають реальний рівень соціальної нерівності, що існує сьогодні в Україні.

У нашій країні значна верства населення, реальні доходи якої нижче прожиткового мінімуму, у той же час має населення з дуже високими доходами. Все це ще раз підтверджує наявність значного розшарування населення України за рівнем економічної забезпеченості та відсутності в країні середнього класу й необхідності його формування $[8$, c. 60].

Для розвитку потужного середнього класу в Україні необхідно, передусім, вирівняти розподіл доходів, а не лише їх розділити між усіма членами суспільства. Через диференціацію доходів та рівня життя населення виникає соціально-економічна проблема - бідність. При цьому, під бідністю слід розуміти такий економічний стан людей, за якого вони не мають мінімуму матеріальних ресурсів для задоволення своїх фізіологічних і соціальних потреб.

Практика свідчить про наявність економічних парадоксів в Україні. Так, за інформацією Державної служби статистики України, за 20132017 pp. спостерігається тенденція до збільшення прожиткового мінімуму на 8,7 \%, але він не відповідає реальному прожитковому мінімуму в зв'язку з тим, що складається на основі занижених і непрозорих показників. Прожитковий мінімум в Україні застосовується лише для того, щоб дати оцінку рівня життя, але цей показник повинен також застосовуватися для встановлення мінімальної заробітної плати. Паралельно, протягом 2013-2017 рр. спостерігалося збільшення номінальних доходів населення. Так, номінальна заробітна плата зросла у 2,18 рази (рис. 3 ).

За даними Міжнародної організації праці, мінімальна заробітна плата у більшості країн світу в кілька разів перевищує фізіологічний прожитковий мінімум і становить 40-60\% середньої заробітної плати [9, с. 128].

Невідповідність мінімальної заробітної плати реальному прожитковому мінімуму, а разом з тим, заниженість оплати праці, зумовлюють негативні наслідків: безробіття, бідність працюючих, «відплив» кваліфікованих працівників із профільних секторів, «відплив» трудових ресурсів у сектор нелегальної зайнятості, зовнішня трудова міграція. Своєю чергою, поєднання перелічених наслідків спричиняє зниження якості трудових ресурсів, обмеження платоспроможності суспільства та, відповідно - внутрішнього ринку, збільшення бюджетних витрат на потреби соціальної 


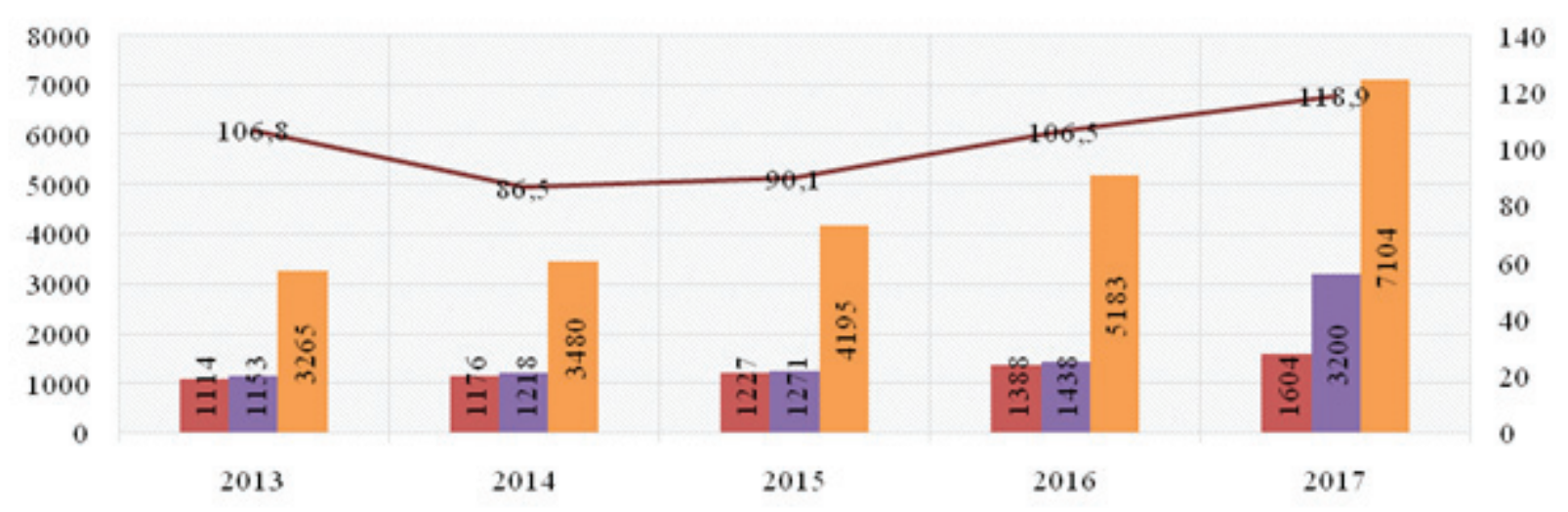

Продатковнй мінімумна одну особу, грн —- Мінімальна заробітна плата, грн
Номінальна заробітна плата, грн $\quad$ - Індекс реальної заробітнойплапн. \%

Рис. 3. Динаміка прожиткового мінімуму, номінальної

та реальної заробітної плати в Україні, 2013-2017 рр. (розраховано авторами за даними [4])

допомоги, обмеженість внутрішніх інвестицій, порушення прав громадян (на якісну медичну допомогу, освітні послуги, судовий захист), і нарешті - відсутність сприятливих умов для проведення реформ у соціальній сфері (пенсійної реформи у сфері охорони здоров'я та соціальної допомоги) [10, с. 57-58].

За даними глобального дослідження «Індекс соціального розвитку», проведеного американською неурядовою організацією Social Progress Imperative, в 2017 р. Україна займає 64 місце серед 128 країн світу та належить до країн з розвитком вище середнього. Індекс визначає рейтинги країн на базі показників, що мають безпосередній вплив на якість життя людей, формуючи соціальний прогрес суспільства, який включає в себе три напрями соціального розвитку: базові людські потреби, добробут і можливості. Лідером світового і європейського рейтингу є Данія з результатом 90,57 . Порівняно з країнами ЄС Україна займає останнє місце з індексом 68,35 (рис. 4).

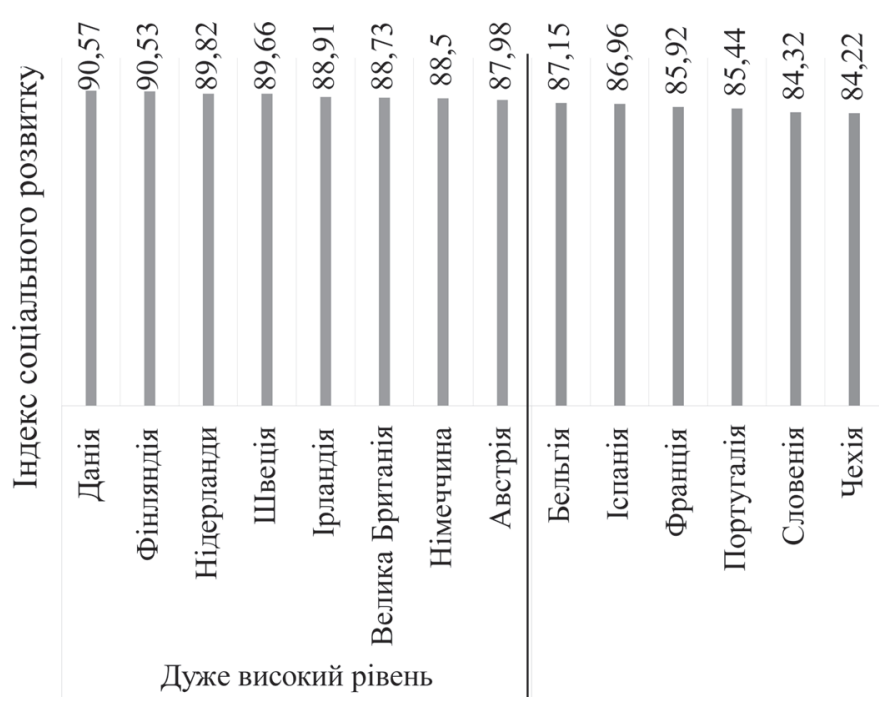

Україна як держава повинна мати стратегічні напрями, за якими здійснюватиметься соціальна політика, а саме:

1. Сфера соціального захисту - розроблення та запровадження комплексу різноманітних соціальних гарантій, які держава має надавати для створення рівноцінних стартових можливостей, загальна обов'язкова державна програма страхування від соціальних ризиків [12].

2. Сфера оплати праці - підвищення рівня оплати праці, розширення прожиткового мінімуму на одну особу як основи мінімальної заробітної плати.

3. Сфера освіти - підготовка кадрів для спеціальностей, що мають попит на ринкові праці та $\epsilon$ частиною науково-технічного прогресу.

4. Забезпечення соціальної безпеки, що відводиться інститутам та організаціям, ресурсам, методам та принципам забезпечення безпеки, які застосовуються кожним ії̈ суб'єктом. Разом з тим, соціальна безпека повинна включати і духовну

Рис. 4. Індекс соціального розвитку в окремих країнах Европи та України, 2017 р., \% (розраховано авторами за даними [11, с. 4]) 
безпеку, що складається з соціальної ідентичності норм моралі, ціннісних орієнтацій, соціальної ідентичності освіти, ідеології, культури і мати суб'єкти їі забезпечення.

5. Реформування охорони здоров'я - запровадження повноцінного страхування населення та діяльності відповідних фондів.

6. Розвиток фізичної культури і спорту - peалізація програми розвитку фізичної культури і спорту серед інвалідів, дітей-сиріт, «важких підлітків», хронічно хворих. Створення національної системи моніторингу, оцінювання й прогнозування стану фізичного здоров'я населення, залучення у сферу коштів із позабюджетних установ.

7. Соціальна підтримка населення - принцип надання адресної соціальної допомоги лише тим домогосподарствам, фактичні прибутки або споживання яких знаходяться нижче прожиткового мінімуму. Проте, останнім часом, він стосується i, перш за все, груп населення, які до цього моменту належали до категорії матеріально забезпеченого населення [13].

Крім того, в сьогоднішніх умовах поглиблення європейської інтеграції України потрібно вирішувати критичні проблеми у сфері зайнятості на ринку праці з метою сприяння соціальному розвитку та більш ефективному використанню наявного людського потенціалу.

3 урахуванням пріоритетів наукових змін та інтеграційних процесів результатом державної політики зайнятості мають стати:

- підвищення соціальних стандартів до європейського рівня;

- науково-технічна інтеграція в міжнародний економічний простір;

- транскордонне співробітництво;

- конкурентоспроможність вищої освіти;

- забезпечення заробітною платою мотиваційної та відповідальної функції як засобу запобігання трудової міграції;

- структурна зміна виробництва;

- розвиток кластерного механізму;

- розвиток сфери послуг [14].

Висновки. Економічна нерівність є однією 3 найбільш досліджуваних форм соціальної нерівності. Дослідження економічної нерівності тісно пов'язане з вивченням бідності, неформальної економіки країни, трудової міграції населення, безробіття, соціальної справедливості та формування соціальної політики. У сучасній Україні рівень економічної нерівності відіграє надзвичайно велику роль у суспільстві. На сьогодні для українського суспільства характерна висока диференціація між різними групами населення. Незважаючи на це, в Україні відсутній потужний середній клас, який мав би бути основою економічної стабільності держави.

Тільки за рахунок упровадження заходів боротьби з економічною нерівністю, які передбача- тимуть адресну допомогу, соціальне страхування, зниження податкового тиску, зниження рівня корупції, введення прогресивного податку, детальний моніторинг кількісних показників оцінки бідності, розвиток демократичних інститутів для забезпечення прав і свобод громадян, можна буде знизити загальний рівень економічної нерівності в Україні.

\section{Література}

1. The World Inequality Report. URL: http:// wir2018.wid.world/files/download/wir2018-fullreportenglish.pdf (дата звернення: 25 січня 2019 р.).

2. United Nations Economic Commissionfor Europe (UNECE). URL: www.unece.org (дата звернення: 20 січня 2019 р.).

3. Коваль Н. В. Соціально-економічна нерівність в Україні та світі: проблеми оцінювання та шляхи їх вирішення. Економіка та держава. 2016. № 2. С. $46-50$.

4. Державна служба статистики України. URL: http://ukrstat.gov.ua (дата звернення: 21 січня 2019 р.).

5. Human Development Indices and Indicators, 2018. Statistical Update. URL: http://hdr.undp. org/sites/default/files/2018_human_development_ statistical_update.pdf (дата звернення: 22 січня 2019 p.).

6. Бригадир В. О. Україна та Європейський союз: соціально-економічна стратифікація за доходами населення. Інтелект XXI. 2017. № 3. С. 9-15.

7. Україна: час вибору. URL: http://razumkov. org.ua/upload/Brochure_EU-CU-7-2013.pdf (дата звернення: 22 січня 2019 р.).

8. Аксьонова I. В. Статистичне забезпечення аналізу соціальної стратифікації та економічної нерівності населення країни. Проблеми економіки. 2017. № 1. С. 55-62.

9. Балакрієва О. М., Головенько В. А., Дмитрук Д. А. та ін. Детермінанти соціально-економічної нерівності в сучасній Україні : монографія / за ред. канд. соціолог. наук О. М. Балакрієвої ; НАН України ; Ін-т екон. та прогнозув. К., 2011. $592 \mathrm{c}$.

10. Вплив мінімальної заробітної плати на зайнятість та економічне зростання. Національна безпека і оборона. 2010. № 7. C. 51-59.

11. Social Progress Index, 2017. URL: https:// www2.deloitte.com/content/dam/Deloitte/ua/ Documents/research/social-progress-index/2017SPI_Executive-Summary-Report.pdf (дата звернення: 25 січня 2019 р.).

12. Маркіна I. А., Аранчій В. I. Інноваційні аспекти формування соціальної безпеки // Інноваційна економіка: теоретичні та практичні аспекти : [монограф.] / за ред. д. е. н., доц. С. І. Масленнікова. Херсон : Грінь Д. С. 2018. С. 14-24. 
13. Markina I., Diachkov D., Oke O. The influence of social responsibility on the quality of life improvement as a significant element of management of sustainable development of cooperatives: Ukrainian and foreign experience. Journal of Research on Trade, Management and Economic Development, Vol. 5, Iss. 2 (10)/2018. URL : http://jrtmed.uccm.md.

14. Большая O. Вплив стану науково-технічного та інноваційного розвитку економіки регіонів на зайнятість населення України. Україна: $a c$ пекти праці. 2012. № 4. С. 11-17.

15. Бондар-Підгурська О. В. Механізм формування середнього класу як основа конкурентоспроможності економіки та сталого інноваційного розвитку України. Економіка та держава. 2012. № 7. С. 22-26.

16. Никифоренко В. Прогнозування розвитку людського потенціалу в контексті світових тенденцій. Україна: аспекти праці. 2012. № 1. С. 14-19.

\section{References}

1. The World Inequality Report. Retrieved from: http://wir2018.wid.world/files/download/wir2018full-reportenglish.pdf [in Eng.].

2. United Nations Economic Commission for Europe (UNECE). Retrieved from www.unece.org [in Eng.].

3. Koval, N. V. (2016). Sotsialno-ekonomichna nerivnist $v$ ukraini ta sviti: problemy otsiniuvanniatashliakhyyikhvyrishennia [Social and economic in equality in Ukraine and in the world: problems of estimation and way soft heir solving]. Ekonomika ta derzhava, 2, 46-50 [in Ukr.].

4. Derzhavna sluzhba statystyky Ukrainy [State Statistics Service of Ukraine]. Retrieved from http:// ukrstat.gov.ua [in Ukr.].

5. Human Development Indices and Indicators, 2018. Statistical Update. Retrieved from http://hdr. undp.org/sites/default/files/2018_human_development_statistical_update.pdf [in Eng.].

6. Bryhadyr, V. O. (2017). Ukraina ta Yevropeiskyisoiuz: sotsialno-ekonomichna stratyfikatsiia zadokhodamy naselennia [Ukraine and the European Union: socio-economic stratification by household income]. Intelekt XXI, 3, 9-15 [in Ukr.].

7. Ukraina: chas vyboru [Ukraine: time of choice]. Retrieved from http://razumkov.org.ua/upload/Brochure_EU-CU-7-2013.pdf [in Ukr.].

8. Aksonova, I. V. (2017). Statystychne zabezpechennia analizu sotsialnoi stratyfikatsii ta ekonomichnoi nerivnosti naselennia krainy [Statistical support for the analysis of social stratification and economic inequality of the population of the country]. Problemy ekonomiky, 1, 55-62 [in Ukr.].

9. Balakriieva, O. M., Holovenko, V. A., Dmytruk, D. A. \& oth. (2011). Determinanty sotsialno-ekonomichnoi nerivnosti v suchasnii Ukraini [Determinants of socio-economic inequality in modern Ukraine]. Kyiv [in Ukr.].

10. Vplyv minimalnoi zarobitnoi platy na zainiatist ta ekonomichne zrostannia [Impact of minimum wage on employment and economic growth]. Natsionalna bezpeka i oborona, 7, 51-59 [in Ukr.].

11. Social Progress Index (2017). Retrieved from https://www2.deloitte.com/content/dam/ Deloitte/ua/Documents/research/social-progressindex/2017-SPI_Executive-Summary-Report.pdf [in Eng.].

12. Markina, I. A., Arancii V. I. (2018). Innovatsiini aspekty formuvannia sotsialnoi bezpeky [Innovative aspects of social security formation]. In Innovative economics: theoretical and practical aspects. Kherson: Grin D. S., 4-24. [in Ukr.].

13. Markina, I., Diachkov, D., Oke, O. (2018). The influence of social responsibility on the quality of life improvement as a significant element of management of sustainable development of cooperatives: Ukrainian and foreign experience. Journal of Research on Trade, Management and Economic Development, vol. 5, iss. 2 (10). Retrieved from: http://jrtmed.uccm. md [in Eng.].

14. Bolshaia, O. (2012). Vplyv stanu naukovotekhnichnoho ta innovatsiinoho rozvytku ekonomiky rehioniv na zainiatist naselennia Ukrainy [The influence of the state of scientific, technical and innovative development of the economy of the regions on the employment of the population of Ukraine]. Ukraina: aspekty pratsi, 4, 11-17 [in Ukr.].

15. Bondar-Pidhurska, O. V. (2012). Mekhanizm formuvannia serednoho klasu yak osnova konkurentospromozhnosti ekonomiky ta staloho innovatsiinoho rozvytku Ukrainy [The mechanism of formation of the middle class as a basis for competitiveness of economy and sustainable innovative development of Ukraine]. Ekonomika ta derzhava, 7, 22-26 [in Ukr.].

16. Nykyforenko, V. (2012). Prohnozuvannia rozvytku liudskoho potentsialu v konteksti svitovykh tendentsii [Predicting human development in the context of global trends]. Ukraina: aspekty pratsi, 1, 14-19 [in Ukr.]. 


\title{
ЕКОНОМІКА ТА УПРАВЛІННЯ НАЦІОНАЛЬНИМ ГОСПОДАРСТВОМ
}

УДК 631.1:330.322

Л. О. Мармуль,

Г. Р. Лаврега

\section{ПРІОРИТЕТИ ІНВЕСТИЦЙНОГО ЗАБЕЗПЕЧЕННЯ СТАЛОГО РОЗВИТКУ СІЛЬСЬКИХ ТЕРИТОРІЙ}

\begin{abstract}
Анотащія. У статті виявлені проблеми дефіциту фінансування та інвестування збереження й сталого розвитку сільських територій. Визначені його причини та ризики. Обгрунтовані нові джерела та можсливі ресурси надходження інвестицій. Розроблені пріоритетні напрями їх використання, серед яких першочергове значення надано всебічним інноваціям. Обгрунтовано визначну роль держсави в стимулюванні та мотиваціях інвестиційної діяльності великого агробізнесу на селі.
\end{abstract}

Ключові слова: сільські території, фінансування, сталий розвиток, інвестиційне забезпечення, пріоритети, інновації, конкурентоспроможність, агробізнес, інфраструктура, управління.

Summary. The article reveals the problems of financing and investment deficit, preservation and sustainable development of rural areas. Determining its causes and risks. New sources and possible resources of investments are substantiated. Priority directions of their use have been developed. Among them, priority is given to comprehensive innovation. The author substantiates the determining role of the state in stimulating and motivating the investment activity of large agribusiness in rural areas.

Key words: rural areas, financing, sustainable development, investment support, priorities, innovation, competitiveness, agribusiness, infrastructure, management.

$$
\text { DOI : } 10.33783 / 1977-4167-2019-46-2-19-22
$$

Постановка проблеми. Формування ефективної моделі інвестування збереження й сталого соціально-економічного розвитку сільських територій залишається актуальною проблемою аграрної політики України. Соціально-економічна активність, рівень та якість життя населення в значній кількості сільських регіонів країни $є$ досить низькими, що зумовлюється багатьма негативними чинниками. Економічну, соціальну та екологічну ситуацію значно погіршують кризові явища в розвитку освіти, охорони здоров'я, культури і спорту, виробничої інфраструктури, малого підприємництва на селі. Тому пріоритетним напрямом вирішення складних соціально-економічних проблем є залучення значних інвестиційних ресурсів, що актуалізує їх наукове обгрунтування.

Аналіз останніх досліджень і публікацій. Проблеми розвитку сільських територій є предметом досліджень відомих вітчизняних та зарубіжних науковців. Ідеться про фундаментальні роботи як окремих наукових колективів, так і науковців:
М. Ігнатенка, I. Ксьонжик, I. Романюк, А. Руснак. У них розглядаються питання їх структури й організації, ефективності сільської економіки, ринку праці й демографічної ситуації. Проте інвестиційне забезпечення сталого розвитку потребує подальшого вивчення.

Мета статті - виявити проблеми й тенденції інвестиційного забезпечення сталого розвитку сільських територій та визначити його нові джерела й пріоритети.

Виклад основного матеріалу дослідження. Внаслідок дії низки несприятливих чинників, як то: недостатня кількість та обмеженість власних, залучених та позикових інвестиційних джерел, низька інвестиційна привабливість та недостатній рівень розвитку сільської економіки, нестабільність та невизначеність ринкового фінансового середовища в країні, реєстрацію надприбуткових гігантських агрохолдингів, агрокорпорацій в офшорах, низький рівень соціальної відповідальності та державно-приватного партнерства вказаний напрям залишається нереалізованим.

(C) Л. О. Мармуль, Г. Р. Лаврега, 2019

Бібліографія ДСТУ 8302:2015:

Мармуль Л. О., Лаврега Г. Р. Пріоритети інвестиційного забезпечення сталого розвитку сільських територій. Вісник Бердянського університету менеджменту і бізнесу. 2019. № 2 (46). С. 19-22.

References (APA):

Marmul, L. O., Lavrega, G. R. (2019). Priorytety investytsiinoho zabezpechennia staloho rozvytku silskykh terytorii [Priorities of investment ensuring sustainable development of rural areas]. Visnyk Berdianskoho universytetu menedzhmentu i biznesu, 2 (46), 19-22 (in Ukr.). 
На думку М. Ігнатенка, інвестування сільської економіки повинне керуватися певними завданнями сталого розвитку та принципами доцільності, економічності, соціальної відповідальності [1, с. 248]. Інвестиції не мають забезпечувати тільки «бюджети проїдання», тобто соціальні виплати, бюджетування закладів соціальної інфраструктури та житлово-комунального господарства. Ідеться, насамперед, про підтримку раціональної спеціалізації та розмірів сільськогосподарського виробництва як основного системоутворюючого чинника, функціонування якого спирається на масштабне ресурсокористування та ресурсозбереження.

Отже, конкурентоспроможність сільських територій визначається станом використання природних ресурсів, зокрема, збереженням їх природних якостей і зміцнення екологічної безпеки. Постають дві взаємопов'язані проблеми: перша - вплив обмеженості природних ресурсів на їх використання і розвиток суспільного виробництва, зростаюче забруднення середовища; друга - необхідність розроблення комплексу заходів щодо ліквідації цієї небезпеки для подальшого розвитку суспільства.

Сучасний стан взаємодії людини і природи характеризується двома протилежними тенденціями: 1) науково-технічна революція створює широкі можливості для перетворення природи; 2) вони викликають вкрай несприятливі наслідки в природних системах. Ці наслідки надзвичайно погіршують умови життя самих людей щодо якості довкілля, зайнятості і саморозвитку, доходів і добробуту, відпочинку; спонукають масові міграції за кордон, депопуляцію населення, деградацію сільських територій.

Стратегічні й тактичні завдання України, а саме намагання інтегруватися до європейського співтовариства, роблять соціально-економічне зростання за рахунок наукових здобутків та їх технологічного застосування однією з найактуальніших проблем [2, с. 7]. Проте інноваційні процеси стримуються цілою низкою організаційних, фінансових та правових чинників, а сама вітчизняна економіка продовжує базуватись на сировинному та низькотехнологічному устрої. Тривала економічна криза, тягар соціально-економічних проблем, гострота регіональних диспропорцій ці реалії сучасного українського сільського життя викликають необхідність їх подолання, що неможливо без активізації інноваційно-інвестиційної діяльності.

Згідно із Законом України «Про інноваційну діяльність», до інновацій належать конкурентоспроможні технології, продукція, послуги й управлінські підходи на підтримку виробництва, бізнеспроцесів і маркетингово-комерційних заходів, які спрямовуються на досягнення суттєвого структурного та якісного поліпшення у виробничій чи соціальній сферах. Дотримуючись класичного визначення інновації як нової функції виробництва, вона «досягається не шляхом дрібних поліпшень старого устаткування чи наявної організаційної схеми, а через введення нових засобів виробництва чи систем його організації» [3, с. 257].

Перехід до інноваційної моделі розвитку потребує значних інвестицій, які треба найбільш оптимально залучати і використовувати для впровадження нововведень. 3 погляду фінансів, інвестиції - усі види активів (коштів), що вкладаються в економічну діяльність з метою отримання доходу, а з точки зору економіки, інвестиції - це витрати на створення, розширення і технічне переозброєння основного і неосновного капіталу.

Л. Мармуль, І. Романюк вважають, що одним з основних елементів розвитку села є соціальна інфраструктура, яку необхідно розвивати на основі інноваційно-інвестиційної діяльності [4, с. 46]. У загальному розумінні соціальна інфраструктура $є$ системою елементів сільського середовища проживання, що виконує функцію забезпечення умов для відтворення населення. В цьому контексті це не лише сфера обслуговування сільського населення, що необхідна для задоволення ряду традиційних потреб сільських жителів. Більшою мірою, це певний механізм координації існуючих характеристик сільського способу життя, спрямований на формування перспективних соціальних форм життедіяльності.

Функції галузей соціальної інфраструктури різні. Одні з них задовольняють духовні потреби людей (освіта, наука, культура, охорона здоров'я, рекреація і т. д.), а інші - фізичні (торгівля і громадське харчування, побутове обслуговування). Саме тому соціальна інфраструктура має економічне і соціальне значення для розвитку суспільства. Її економічне значення виявляється у тому, що вона надає послуги, необхідні для відтворення робочої сили, зростання продуктивності їі праці. Соціальна роль даної сфери полягає у підвищенні рівня і поліпшенні умов життя людей. Тому, на переконання А. Руснак, політика розвитку сільських територій повинна включати як сільськогосподарський, так і загальноекономічний, соціальний розвиток, диверсифікацію виробництва, сприяння розширенню підприємництва та раціональне управління навколишнім середовищем [5, с. 176].

Особливої уваги потребує стан сільської інфраструктури, промисловості з перероблення сільськогосподарської продукції, місцевих ремесел і сфери послуг. Головна мета процесу розвитку сільських територій - визначення на основі розгортання інноваційно-інвестиційної діяльності належних умов для організації достатньо високого рівня сфери послуг, упровадження визначених суспільством стандартів рівня життя, забезпечення економічної ефективності виробництва і дов- 
гострокового збереження навколишнього середовища. Таким чином, інноваційно-інвестиційне забезпечення ефективно працюючих підприємств у сільському господарстві, а також сервісних формувань на селі сприяє зайнятості населення і зміцненню соціально-економічних каркасів сільських територій [6, с. 37].

Інвестиційна сфера сільських територій є відкритою системою, внутрішня структура якої складається з сукупності взаємопов'язаних об'єктів інвестування та суб’єктів інвестиційної діяльності (інвесторів і користувачів), що здійснюють інвестиційну діяльність на даній території. На вході такої системи знаходяться зовнішні інвестиції як у матеріальній, так і в грошовій формі, а на виході - поступаючий за іiі межі дохід від експлуатації введеного об'єкта інвестицій, продукція і послуги. Для розвитку сільської громади їі інвестиційна сфера $є$ найважливішим компонентом, вона $€$ підсистемою системи соціально-економічного розвитку. В цій сфері формуються внутрішні пропорції між інвестиціями і їх соціальною та економічною віддачею, накопиченням і споживанням, капітальними вкладеннями та приростом основних фондів [7, с. 128].

Суб'єктами інвестиційної діяльності на сільських територіях $є$ інвестори (вкладники, покупці, замовники, кредитори та ін.) та користувачі об'єктів інвестування (юридичні і фізичні особи та місцеві органи влади). Інвестиції, як об'єкти інвестиційної діяльності, мають подвійний характер. Будучи, з одного боку, інвестиційними ресурсами, вони виражають невикористаний для споживання дохід. 3 іншого боку, це витрати (вкладення), що дають приріст вартості майна. Як ресурси можуть виступати грошові кошти; матеріальні цінності; нематеріальні активи (майнові, інтелектуальні та інші права).

Деталізація класифікації фінансових джерел інвестиційного забезпечення сталого розвитку сільських територій дозволяє визначити можливі механізми додаткового інвестування [8, с. 341]. Отже, джерелами їх фінансування й інвестиційного забезпечення можуть бути: власні (приватні), державні, залучені, позикові або кредитні, змішані вкладення. Перед сільськими територіальними громадами, так само як перед районами, регіонами і державою загалом, стоїть складне і багатопланове завдання реалізації передумов інвестиційного підйому. Особливо важливою стає роль держави при подоланні інвестиційного спаду.

Держава може застосовувати різні форми своєї участі в інвестиційному процесі. Найважливішим 3 них є регулювання інвестиційного ринку. Водночас і в ринковій економіці держава є безпосереднім інвестором, що виконує достатньо важливу роль у розвитку економіки. В першу чергу, вона інвестує бюджетні кошти в ті сегменти економіки, які є непривабливими для приватних інвесторів з точки зору отримання доходів, але мають важливе соціальне і державне значення. Для України це, насамперед, сільські території, особливо їх соціальна сфера.

Висновки. У сільських регіонах України необхідна активізація діяльності місцевої влади, спрямованої на формування сприятливих умов співпраці з потенційними закордонними інвесторами. Боротьба за світові інвестиційні ресурси стає більш жорсткішою з огляду на зростання кількості претендентів з числа країн, які ставлять на меті пришвидшення економічного зростання. Аналіз світових тенденцій щодо здійснення ефективної політики залучення інвестицій, зокрема, іноземних, дає змогу систематизувати інструменти іiі реалізації та адаптувати до розвитку конкретної території або громади.

\section{Література}

1. Ігнатенко М. М. Стратегії та механізми управління розвитком соціальної відповідальності суб’єктів господарювання аграрної сфери економіки : монографія. Херсон: Айлант, 2015. 470 с.

2. Юрчишин В. В. Сільські території як системоутворюючі фактори розвитку аграрного сектора економіки. Економіка АПК. 2012. № 3 (125). C. $3-10$.

3. Котенко Н. М. Формування джерел інвестиційної діяльності на сільських територіях. Інноваційна економіка. 2012. № 9 (35). С. 255-258.

4. Мармуль Л. О., Романюк І. А. Ринок праці та зайнятість населення сільських територій: теорія і практика регулювання : монографія. Херсон : Айлант, 2015. 266 с.

5. Славкова О. П. Розвиток сільських територій: теорія, методологія, практика : монографія. Суми : СНАУ, 2010. 330 с.

6. Кісіль М. І. Стратегічні напрями інвестиційного забезпечення розвитку сільського господарства. Економіка АПК. 2012. № 9. С. 36-39.

7. Притула Х. М. Аналіз зовнішніх факторів розвитку сільських територій. Науковий вісник НЛТУ України. 2011. Вип. 21.10. С. 124-131.

8. Талавиря М. П. Шляхи удосконалення організаційно-економічного механізму державної підтримки розвитку сільських територій : монографія. Ніжин: ПП Лисенко М. М., 2009. 424 с.

9. Батуріна Г. М. «Родова садиба» - один із напрямів сталого розвитку сільських територій. АгроІнКом. 2013. № 4-6. С. 102-109.

10. Павлов О. І. Сільські території України: функціонально-управлінська модель. Одеса : Астропринт, 2009. 344 с.

\section{References}

1. Ihnatenko, M. M. (2015). Stratehiyi ta mekhanizmy upravlinnya rozvytkom sotsialnoyi 
vidpovidalnosti subyektiv hospodaryuvannya ahrarnoyi sfery ekonomiky [Strategies and mechanisms of management of development of social responsibility of subjects of managing of agrarian sphere of economy]. Kherson, Aylant (in Ukr.).

2. Yurchyshyn, V. V. (2012). Silski terytoriyi yak systemoutvoryuyuchi faktory rozvytku ahrarnoho sektora ekonomiky [Rural territories as system-forming factors of development of agrarian sector of economy]. Ekonomika APK, 3 (125), 3-10 (in Ukr.).

3. Kotenko, N. M. (2012). Formuvannya dzherel investytsiynoyi diyalnosti na silskykh terytoriyakh [Formation of sources of investment activity in rural areas]. Innovatsiyna ekonomika, 9 (35), 255-258 (in Ukr.).

4. Marmul, L. O. \& Romanyuk, I. A. (2015). Rynok pratsi ta zaynyatist naselennya silskykh terytoriy: teoriya i praktyka rehulyuvannya [Labor market and employment of rural population: theory and practice of regulation]. Kherson: Aylant (in Ukr.).

5. Slavkova, O. P. (2010). Rozvytok silskykh terytoriy: teoriya, metodolohiya, praktyka [Rural development: theory, methodology, practice]. Sumy, SNAU (in Ukr.).

6. Kisil, M. I. (2012). Stratehichni napryamy investytsiynoho zabezpechennya rozvytku silskoho hospodarstva [Strategic directions of investment support of development of agriculture]. Ekonomika $A P K$, 9, 36-39 (in Ukr.).

7. Prytula, KH. M. (2011). Analiz zovnishnikh faktoriv rozvytku silskykh terytoriy [The analysis of external factors of development of rural territories]. Naukovyy visnyk NLTU Ukrayiny, 21.10, 124-131 (in Ukr.).

8. Talavyrya, M. P. (2009). Shlyakhy udoskonalennya orhanizatsiyno-ekonomichnoho mekhanizmu derzhavnoyi pidtrymky rozvytku silskykh terytoriy [The ways of improvement of organizationaleconomic mechanism of state support of development of rural territories]. Nizhyn, PP Lysenko M. M. (in Ukr.).

9. Baturina, H. M. (2013). «Rodova sadyba»odyn iz naprjmiv staloho rozvytku silskych terytoriy [«Family Homestead» - one of the directions of sustainable development of rural territories]. AhroInKom, 4-6, 102-109 (in Ukr.).

10. Pavlov, O. I. (2009). Silski terytoriyi Ukrayiny: funktsionalno-upravlinska model [Rural territories of Ukraine: functional and managerial model]. Odesa, Astroprynt (in Ukr.). 


\title{
УДОСКОНАЛЕННЯ ІНСТИТУЦЙНОГО ЗАБЕЗПЕЧЕННЯ ЗАЛУЧЕННЯ ІНОЗЕМНИХ ІНВЕСТИЦІЙ В ЕКОНОМІКУ УКРАЇНИ
}

\begin{abstract}
Анотація. У статті обгрунтовано важливість залучення іноземних інвестицій в економіку Украӥни. Виявлено, що ефективність та інтенсивність цього процесу залежать від інституційного забезпечення. Як його складники визначені податкові, фінансові, адміністративні, нормативно-правові, ресурсно-функціональні. Встановлено проблеми та визначено напрями розвитку окремих інститутів. Обгрунтовано пріоритетні галузі національної економіки для залучення іноземних інвестицій.

Ключові слова: іноземні інвестиції, політика, залучення, інституційне забезпечення, національна економіка, пріоритети, напрями.

Summary. The article substantiates the importance of attracting foreign investments to the economy of Ukraine. The effectiveness and intensity of this process is found to depend on institutional support. As its components are determined tax, financial, administrative, regulatory, resource and functional. Problems were identified and directions of development of individual institutes were determined. Priority sectors of the national economy for attracting foreign investments are substantiated.
\end{abstract}

Key words: foreign investments, policy, involvement, institutional support, national economy, priorities, directions.

$$
\text { DOI : } 10.33783 / 1977-4167-2019-46-2-23-26
$$

Постановка проблеми. На сучасному етапі розвитку світового та національного господарства однією з найактуальніших проблем для України, інших країн з ринковою економікою та країн, що розвиваються, є залучення та ефективне використання іноземних інвестицій. Успішне вирішення цього завдання залежить, насамперед, від виваженої державної політики у сфері регулювання іноземного інвестування. Саме вітчизняні та іноземні інвестиції сприяють упровадженню інновацій, модернізації економіки, міжнародній інтеграції та співпраці.

Аналіз останніх досліджень і публікацій. Тема залучення іноземних інвестицій в Україну знайшла відображення в дослідженнях, що проводяться за кордоном та у вітчизняних наукових установах і навчальних закладах. Останнім часом видано значну кількість публікацій щодо залучення іноземних інвестицій в Україну. Широко відомі дослідження, які здійснювали Я. Медвідь [1], В. Любімов [2], Н. Шевченко [3], М. Ігнатенко, В. Антошкін, О. Круковська, В. Малишко $[4,5]$ та інші відомі науковці. Проте проблема інституційного забезпечення іноземного інвестування потребує подальшого удосконалення.

Мета статті - визначити основні напрями та заходи щодо інституційного забезпечення залучення іноземних інвестицій у національну економіку.

Виклад основного матеріалу дослідження. Важливу роль у залученні та використанні іноземних інвестицій відіграють державні інститути. Саме вони регулюють рівень надходження іноземних інвестицій через реалізацію інвестиційної політики. Сучасна інвестиційна політика в Україні має доволі суперечливий та непослідовний характер, оскільки не завжди враховується специфіка національної економіки, іiї проблеми, структурні зрушення. Тому інституційне забезпечення інвестиційної політики має бути спрямоване на усунення перешкод та запровадження стимулів для інвестування, захисту прав інвесторів [1]. Його інститути мають включати регулювання умов інвестиційної діяльності, яке здійснюють органи виконавчої влади країни загалом й окремі суб'єкти відповідно до чинного законодавства. Державне регулювання іноземного інвестування має грунтуватися на принципах взаємної відповідальності іноземного інвестора і держави: дотримання основних прав і свобод іноземних інвесторів; юридичної відповідальності іноземних інвесторів за порушення закону або міжнародних договорів; заохочення іноземних інвесторів, які спрямовують інвестиційні ресурси у програми (проєкти), визначені

(C) Н. П. Новак, 2019

Бібліографія ДСТУ 8302:2015:

Новак Н. П. Удосконалення інституційного забезпечення залучення іноземних інвестицій в економіку України. Вісник Бердянського університету менеджменту і бізнесу. 2019. № 2 (46). С. 23-26.

References (APA):

Novak, N. P. (2019). Udoskonalennia instytutsiinoho zabezpechennia zaluchennia inozemnykh investytsii vekonomiku Ukrainy [Improvement of institutional support for attracting foreign investments in the Ukrainian economy]. Visnyk Berdianskoho universytetu menedzhmentu i biznesu, 2 (46), 23-26 (in Ukr.). 
державою як пріоритетні; удосконалення законодавства щодо іноземних інвестицій [2].

Політика залучення іноземних інвестицій має відповідати певним вимогам і умовам, що повинні закласти основу стійкого припливу капіталу. Серед цих вимог можна виділити такі: стабільність законодавства, формування чіткої нормативноправової бази регулювання іноземних інвестицій; введення конкурентоспроможного рівня податків, тарифів і пільг, які відповідають умовам іноземних інвестицій, що сформувалися в інших країнах, які $€$ конкурентами України як ринки вкладення іноземного капіталу; наявність гнучкої фінансової політики в галузевих і регіональних напрямах, що забезпечує досягнення пріоритетних цілей розвитку національного господарства [3].

Медвідь Я. Ф., проаналізувавши спеціальні функції державного управління інвестиційною діяльністю, умовно розділив їх на дві групи: функції із залучення інвестицій та функції з використання інвестицій. До функцій держави із залучення інвестицій належать:

1) формування державної політики щодо залучення інвестицій;

2) участь у міжнародному економічному співробітництві;

3) визначення пріоритетних напрямів використання інвестицій;

4) здійснення моніторингу й обліку інформації щодо джерел інвестицій, потреб у їх залученні, напрямів та ефективності використання;

5) створення сприятливих умов для діяльності інвесторів на території України та ін. [1].

Пріоритетними напрямами для залучення й використання іноземних капіталовкладень доцільно вважати: освоєння незадіяного науковотехнічного потенціалу й розвиток наукоємних виробництв; нарощування експортного потенціалу; забезпечення раціонального ресурсокористування; розвиток конкурентоспроможного виробництва та видів діяльності. Іноземний капітал необхідно спрямовувати у видобувні й переробні галузі, що дасть змогу обновити їх виробничі фонди, підвищити ефективність виробництва i значно розширити експортний потенціал країни; у ракетобудівну, атомну, енергетичну, IT галузі 3 метою розвитку наукоємних виробництв; у фармацевтичну, побутово-хімічну, харчову промисловість, сільське господарство, у т. ч. органічне виробництво [4].

Світова практика виробила універсальний набір заходів, які тією або іншою мірою вживаються для залучення іноземних капіталів. Серед них виділяють такі інституційні інструменти:

- податкові: встановлення прямих податкових пільг, відстрочення сплати податків за інвестування капіталу, маніпулювання рівнем податку;
- стимули, пов'язані з амортизаційними відрахуваннями, оскільки пришвидшена амортизація стає одним із найчастіше використовуваних методів підтримки закордонних інвесторів.

Також це фінансові методи стимулювання:

- різні субсидії, позики і гарантії їхнього надання в разі виконання інвестором певних завдань, наприклад, освоєння конкретних регіонів, галузей промисловості;

- адміністративні й нормативно-правові методи;

- ресурсно-функціональні, що спрямовані на створення загального середовища ефективного функціонування іноземного капіталу в економіці - від забезпечення необхідними факторами виробництва, інформацією і службами управління до розвитку транспортної мережі, інших комунікацій тощо.

Практика показує, що фінансовим стимулам надають переваги промислово розвинені країни, адже вони дають змогу сконцентрувати зусилля на досягненні конкретних цілей. Країни, які розвиваються, у т. ч. Україна, більше використовують податкові засоби стимулювання, що пов'язано, зокрема з браком фінансових засобів. Доцільно також здійснювати утворення підприємств з участю іноземного капіталу. При цьому вони мають здійснювати соціальну відповідальність щодо регіонів свого розміщення й отримання прибутків. Особливо це стосується сільських територій та сільських громад.

У перспективі для суб'єктів управління агросферою має бути прагнення не просто витрачати кошти на благодійність та вкладати кошти, а брати участь у програмах та проєктах, які створюють «нову соціальну вартість». Мета їх полягає в тому, щоб за аналогією з бізнесом досягти максимальної соціальної віддачі від вкладених коштів. Такі підходи є основою соціальних інвестицій, які мають стати провідною тенденцією розвитку та реалізації благодійності програм сучасних бізнес-структур. Благодійні соціальні інвестиції дозволяють бізнесу поєднувати органічно, а не прагматично, мотиви милосердя і є перспективною практичною формою реалізації соціальної відповідальності.

Основними напрямами таких благодійних соціальних інвестицій є:

- створення інфраструктури благодійності, розвиток іiі організаційно-методичного та кадрового забезпечення шляхом забезпечення формування відповідного ресурсу та інформаційних центрів;

- пошук найбільш плідних, креативних та перспективних ідей, спрямованих на вирішення духовно-моральних та соціальних проблем і створення необхідних умов для їх реалізації;

- залучення до благодійності більшої кількості структур, насамперед - органів влади, гро- 
мадських та добровільних організацій, підтримка їх суспільно корисної діяльності;

- розвиток інтернет-простору до благородної справи - форумів, банків ідей та методичних розробок;

- підтримка самоорганізації суспільно корисних благодійних ініціатив на національному, регіональному та місцевому рівнях.

Головні та найпопулярніші сфери доброчинних соціальних інвестицій:

- соціальна сфера - через створення та підтримку відповідної інфраструктури для допомоги соціально вразливим верствам населення: дітям, матерям, людям похилого віку, інвалідам, ветеранам, нужденним;

- культура та мистецтво - єдине або постійне забезпечення культурних установ, бібліотек, а також художників, літератури, кіно, власне культурні заходи;

- освіта - надання грантів для вчителів та студентів, оплата навчання за кордоном, допомога у створенні матеріально-технічних ресурсів навчального процесу;

- наука - допомога у фундаментальній та прикладній науці в Україні, розвиток інноваційних технологій (у т. ч. соціальних технологій), організаційна та фінансова підтримка досліджень, які не мають прямого комерційного характеру, пошук і реалізація рішень екологічних та інших значущих проблем суспільства;

- охорона здоров'я - допомога медичним установам, придбання обладнання, медикаментів, оплата підготовки та перепідготовки працівників;

- збереження навколишнього середовища фінансування екологічних програм, захист навколишнього середовища, вирішення екологічних проблем сільських території загалом;

- підтримка засобів масової інформації виділення грантів, створення матеріально-технічних ресурсів [5].

Отже, перед Україною постають принципово важливі цілі для реалізації заходів, спрямованих на покращення інвестиційного середовища та вдосконалення механізму залучення іноземних інвестицій в економічну систему країни. Для того, щоб створити ефективну систему залучення іноземних інвестицій, насамперед, потрібно сформувати відповідну законодавчу базу.

Наявність суперечностей i невизначеності окремих важливих питань законодавства зумовлює необхідність внесення змін до Закону України «Про власність» і до Земельного кодексу України стосовно визначення майнових прав іноземних інвесторів. Ідеться й про формування ринку земельних ресурсів. Потрібно на державноправовому рівні уточнити питання про концесії (визначення можливостей отримання прибутку іноземними інвесторами від розвідування, розроблення, видобування та експлуатації природних ресурсів). Потребує ретельного обгрунтування система валютного регулювання.

Висновки. Удосконалення інституційного забезпечення є вагомим чинником активізації надходження іноземних інвестицій в економіку України. При цьому основними його складниками визначені податкові, фінансові, адміністративні й нормативно-правові, ресурсо-функціональні. Останні спрямовані на удосконалення реального середовища здійснення інвестиційної діяльності. Велике значення має інститут моніторингу надходження інвестицій, їх обсягу та структури. Саме він дозволяє мати правильну інформацію для прийняття управлінських рішень щодо їх розподілу на перспективу.

\section{Література}

1. Медвідь Я. Ф., Ніколаєва Я. І. Державне управління інвестиційною діяльністю в Україні. Наукові праці МАУП. 2011. Вип. 1. С. 107-112.

2. Любімов В. І. Особливості державного регулювання іноземних інвестицій: закордонний досвід. Економічний простір. 2009. № 21. С. 65-71.

3. Шевченко Н. О. Уникнення загроз в державній політиці залучення іноземних інвестицій в AПК. URL: http: // http://www.nbuv.gov.ua.

4. Ignatenko M. M., Novak N. P. Development of regional programs for the development of agrarian enterprises with organic production on the basis of the European and international experience. Baltic Journal of Economic Studies. Vol. 4, No. 4. 2018. C. 126-133.

5. Ihnatenko M., Antoshkin V., Krukovska O., Malyshko V., Marmul L. Social investments as the highest manifestation of implementation of social responsibility of the companies of agribusiness. International Journal of Recent Technology and Engineering. Volume-8. Issue-3. September 2019. C. 7124-7132.

\section{References}

1. Medvidj Ja. F., Nikolajeva Ja. I. (2011). Derzhavne upravlinnja investycijnoju dijaljnistju $v$ Ukrajini [Public administration of investment activity in Ukraine]. Naukovi praci MAUP, 1, 107-112.

2. Ljubimov V. I. (2009). Osoblyvosti derzhavnogho reghuljuvannja inozemnykh investycij: zakordonnyj dosvid [Features of state regulation of foreign investments: foreign experience]. Ekonomichnyj prostir, 21, 65-71.

3. Shevchenko N. O. Unyknennja zaghroz v derzhavnij polityci zaluchennja inozemnyx investycij $v$ $A P K$ [Avoiding threats in the state policy of attracting foreign investment in agriculture]. Retrieved from http: // http://www.nbuv.gov.ua.

4. Ignatenko M. M., Novak N. P. (2018). Development of regional programs for the development of agrarian enterprises with organic production on the ba- 
sis of the European and international experience. Baltic Journal of Economic Studies, vol. 4, no. 4, 126-133.

5. Ihnatenko M., Antoshkin V., Krukovska O., Malyshko V., Marmul L. (2019). Social investments as the highest manifestation of implementation of social responsibility of the companies of agribusiness. International Journal of Recent Technology and Engineering, vol. 8. iss. 3, 7124-7132.

УДК 351:68:002.8

H. V. Ortina, O. A. Leushyna

\title{
THE INFLUENCE OF STATE POLICY ON THE INNOVATION ACTIVITY OF SUSTAINABLE BALANCED ECONOMIC GROWTH IN THE GLOBALIZATION
}

\begin{abstract}
Анотація. У статті зроблено спробу теоретично дослідити та практично обгрунтувати шляхи вдосконалення інвестиційної та інноваційної політики країни в умовах глобалізації. Виявлено негативні наслідки неефективної державної політики, яка перешкоджає довірі до інвестиційної діяльності в національну економіку. Зазначено, що застаріла виробнича база, зношене обладнання заважає створенню нової державної інноваційно-інвестиційної політики країни. Відзначено, що сучасний етап розвитку вимагає від адміністрації не лише сприяння залученню інвестицій з усіх можливих джерел, але й контролю за їх цільовим використанням, що дає змогу активізувати виробничі та технологічні фактори економічного розвитку. Також запропоновано шляхи підвищення інвестиційної привабливості країни.
\end{abstract}

Ключові слова: інвестиції, новації, державна політика, конкурентоспроможність, освіта, науковотехнічний прогрес, реальний сектор економіки.

Summary. The article investigates and theoretically substantiates ways to improve the country's investment and innovation policy, reveals negative manifestations of imperfect state policy that impede the smooth investment in the national economy. It is stated that it is impossible to create a new state innovation and investment policy of a higher level of technological development on a morally outdated production base, worn-out equipment of industrial enterprises and scientific centers. It is stated that at the present stage of development, the state administration requires not only the promotion of attracting investments from all possible sources, but also the control over their targeted use, which makes it possible to activate production and technological factors of economic development. Ways to improve the investment attractiveness are outlined and suggested. In the current conditions of dynamic economic development, fierce competition in the market between economic entities, development of science and technology, intellectualization of the main factors of production, it is necessary for enterprises to form effective mechanisms of implementation of innovation policy that will allow to achieve competitive advantages in the domestic and foreign markets.

Key words: investments, innovations, public policy, competitiveness, education, scientific and technological progress, real economy.

$$
\text { DOI : } 10.33783 / 1977-4167-2019-46-2-26-31
$$

Problem statement. Overcoming technological backwardness of the national economy, reaching the indicators of economically developed countries in technological leadership and competitiveness require a significant activation of entrepreneurial activity in the innovation sphere. It is impossible to solve this problem without modernizing the ways and mechanisms of this development, changing its priorities, in- stitutions, relations between the subjects of economic activity, resource base. The success of measures aimed at developing the national economic system within the framework of the anti-crisis strategy will be determined by the extent to which they will be complemented by appropriate transformations and efforts in the institutional, socio-cultural and political spheres. In particular, during the years of market transformations

(C) Г. В. Ортіна, О. А. Лєушина, 2019

Бібліографія ДСТУ 8302:2015:

Ортіна Г. В., Лєушина О. А. Вплив державної політики на інноваційну діяльність стійкого збалансованого зростання економіки в умовах глобалізації. Вісник Бердянського університету менеджменту і бізнесу. 2019. № 2 (46). С. 26-31.

References (APA):

Ortina, H. V., Leushyna, O. A. (2019). Vplyv derzhavnoi polityky na innovatsiinu diialnist stiikoho zbalansovanoho zrostannia ekonomiky $v$ umovakh hlobalizatsii [The influence of state policy on the innovation activity of sustainable balanced economic growth in the globalization]. Visnyk Berdianskoho universytetu menedzhmentu i biznesu, 2 (46), 26-31 (in Eng.). 
in Ukraine, no complete institutional environment necessary for stable and effective economic activity of economic entities, their economic and technological progress was created. However, no strategic goal in the field of socio-economic development can be successfully implemented in the absence of an institutional environment that ensures the harmonization of the interests of members of society and the achievement of a united perception of their development goals.

Analysis of recent research and publications. Modern theories of managerial opinion on the peculiarities of investment and innovation policy of crisis management are based on the works of reputable foreign and domestic scientists, among them: O. Datsii, L. Antonova, V. Bakumenko, L. Baranovskyi, O. Bielov, K. Berne, I. Binko, M. Bolduiev, B. Buzan, O. Vlasiuk, V. Voloshyn, V. Heiets, B. Hriier, K. Morhenzan, P. Novak, O. Novykova, L. Olvei, Y. Orlenko, S. Pyrozhkov, H. Pasternak-Taranushchenko, V. Ponomarenko, V. Ponomarov, P. Pryhunov, V. Senchahov, V. Sidak, A. Sukhorukov, V. Shlemko, R. Oleksenko, H. Ortina and others.

Purpose of the article. The study is to develop a mechanism for innovation at the national level to ensure the economic development of the country, the well-being of the population and national security of the state. For the purpose of this task was set: propose ways to attract additional investment for innovative modernization of the real economy. Methodological basis research is a scientific method of research and special methods based on modern scientific principles of management, economics and related sciences. In the work used: abstract-logical method; methods of analysis and synthesis; analytical modeling; system approach, etc.

Presenting main material. The strategic direction of modernization of the sectoral structure of the national economy brings to the fore the problem of mobilization of the necessary resources, including by the curtailment of structurally depressed industries. In the process of eliminating or partially curtailing, resources, areas, labor are released, which can then be redeployed to priority sectors. The preparation of this process should be preceded by a preparatory period, the duration of which will depend on the country's accumulated economic potential, the current state of the economy and the depth of the structural crisis. During this period, the industries and productions to be curtailed should be identified, as well as the composition of the measures and the specific timing of their holding. The first step in developing structural transformation programs is to rank the sectoral structure of the economy into groups of industries: - basic industries that are the basic constructs of the national economy and determine its independence; - promising industries that determine the basis of economic growth; structural-depressed industries, sub-sectors, enterprises and industries to which environmentally harmful, resource - and labor-intensive ones are based, based on outdated technologies and unpromising directions of economic activity. The implementation of structural adjustment programs requires a change in investment priorities (the cost of modernization and reconstruction in developed countries is $70-90 \%$ of total investments in fixed assets), and the sectoral structure of investment through cross-sectoral and international capital outflows. The latter involves the redistribution of investment flows between industries and within large corporations in favor of the most promising industries (industries) and the refusal to invest in structurally depressed activities. This process is carried out through diversification or an exchange channel to solve the problem of financing innovative activities can facilitate the development of effective partnership between the state, business and academia. It is well known that private firms are reluctant to invest in expensive and risky basic research. Competition between private firms begins after the result of basic research. However, the situation can be changed by providing support for the stage of basic research by the state. In Japan, for example, the state funds the start of research, and private firms, having learned about the support of the project by the state, invest their capital in further development. In the final stages, the project is carried out entirely by private firms. Banks play a significant role in financing innovation. Banks can lend to all stages of the innovation lifecycle. Usually, the loan is issued under the funds available to the applicant, state guarantees, concluded contracts for the purchase of the new product produced through the use of the loan. In this case, the interest rate on the loan for innovation activities should be set depending on the efficiency of innovations, their payback period, compliance with the priorities of scientific and technological development and the degree of risk. The bank can co-own the result, offsetting its costs in the form of operating income from the innovation. The financing agreement may specify the period after which the share of the bank's funds in financing the innovation at the request of the borrowing legal entity may be redeemed by the bank. Banks can participate in the organization of a comprehensive examination of innovation, attracting highly qualified specialists. Typically, the cost of a comprehensive examination is $1 \%$ of the estimated cost or determined cost of development. The Bank may also provide information, brokerage, advisory, scientific and technical, advertising, forecasting and market services to innovative enterprises. The Bank may become the organizer of jointstock financial projects and joint ventures. The obstacles to the widespread involvement of commercial banks in the process of lending to innovative projects in Ukraine are, as a rule, the lack of methodological aspects of lending to innovative enterprises that take into account risk factors. In our opinion, the repayment of a commercial bank loan by an innovative en- 
terprise should be based on a differentiated approach to the interest rate. Factors that should be taken into account when determining the interest rate include: profit from the implementation of an innovative project; - the amount of costs, which is determined at the stage of development work on the basis of functional cost analysis; - the share of the investment fund's or bank's borrowings in the total cost reimbursement; term of implementation of an innovative project that defines the terms of attracting credit for its execution and repayment to their lender. Given the risky nature of innovative projects and the uncertainty of the end result, it can be expected that the planned values of these factors may not coincide with their actual values. The ratio of the actual and the planned value of the factors leads to a change in the interest rate, which will help the orientation of the borrowers to achieve the best results when using the loan. Formation of securities institutions (investment banks and funds, insurance companies), which aim to ensure free movement of shares and other financial instruments, will also contribute to the development of innovative entrepreneurship in Ukraine. Broad opportunities lie, for example, in the use of secondary financial instruments; the use of options allows the company to receive interest-free credit, and the buyerbroker makes a partial prepayment of future production of new products. However, the contract stipulates that in case of refusal of supply, the interest-free loan will be converted into a commercial one with a corresponding rate. An urgent need is the formation in Ukraine of a system of venture financing of innovative enterprises of the real sector of the economy, because the venture business organically combines two types of entrepreneurship: financial and innovative. It is advisable to create two funds: sectoral and regional. The reason for the low rate of development of venture business in Ukraine is, on the one hand, that the state does not assume real risks of innovative activity, while abroad during the creation of venture funds the state contribution makes up to $40 \%$ of the capital of the funds. On the other hand, the current legislation lacks legal forms adequate to the needs of the venture business, and the procedures for registering venture funds are complex. Due to stock market underdevelopment, there is a low level of venture investment liquidity and little choice of available strategies. There are also problems with the lack of qualified managers. Due to the above circumstances, most of the venture capital investments are directed not to new companies but to existing ones. Venture Fairs may be an Instrument for Activating Interest in Venture Financing for Innovation Projects. The Venture Fairs organization model was first developed in the United States. In the process of fairs three main tasks are solved, such as assessment of investment potential in high-tech sphere, provision of intermediary services to manufacturers and consumers of high-tech projects, raising the educational level of par- ticipants in the use of various financial instruments. In the US, venture capital fairs are attracting to the knowledge-intensive sector more than 90 million dollars for a year. Transformation of knowledge into the main driving force of society's development, the growing pace of innovation renewal requires a radical restructuring of the education system. Education should become a continuous and strategic process that will enable professionals in the work process to acquire new knowledge for innovative industries and fields of activity. This approach involves state support for education in promising areas, as well as subsidizing job creation in knowledge-intensive industries. Since manufacturing is the main consumer of innovation, it is necessary to ensure its susceptibility to innovation, which is achieved if such conditions are met: - innovation is a prerequisite for survival and maintaining competitiveness of production; - production must or may attract the necessary resources for innovation; there is comprehensive information on the possibilities of innovative transformations and the expected effectiveness of innovative projects; - state policy provides the necessary and sufficient preferences to motivate innovation activity of enterprises, taking into account the risks and long payback periods of innovation. One of the main conditions for effective functioning of national innovation system (NIS) is the integration of the innovation sphere into the market space. However, despite the fact that the commercialization of scientific results in itself creates the preconditions for the growth of the innovation sphere in the system of market relations, without appropriate organizational and economic transformations this task cannot be solved. Increasing the role of innovation at the current stage of national economy development is linked, on the one hand, to the highest level of competition, and on the other, with the transformation of innovation into the most powerful instrument of competition. The main purpose of innovations is to increase strategic advantages over other competitors. The above circumstances indicate that there is a deep relationship between innovation and competition. A successful innovator in a certain, albeit limited, period of time has monopoly power over the market. And only then, under the influence of the process of diffusion of innovations and / or the emergence of new scientific and technological achievements, its economic dictate is broken, which does not exclude the restoration of lost monopoly power by the development of new innovations or the transfer of this power to another innovator. It is the acquisition of monopoly power over the market that is the most important market mechanism that stimulates innovation activities.

The international involvement of capital in structural transformation contributes to tasks such as creation of a multinational company, international strategic alliances of other global business networks or joining existing associations to share existing capacity 
and competencies; reduction of the level of non-equivalent exchange of the country in the world markets of high-tech goods, technologies, intellectual services. Structural adjustment programs must also be supported by appropriate government regulation mechanisms. In our opinion, special attention should be paid to: formation and support of demand for products of perspective industries using mechanisms of state orders of subsidies to prices and selective forms of customs regulation; - managing capital depreciation processes to increase the investment capacity of enterprises at their own expense; - strengthening of currency regulation aimed at accumulation of foreign exchange resources in the country for the purpose of structural modernization; - strengthening state control over the distribution of profits of wholly or partly state-owned enterprises and transforming it into domestic investment in accordance with selected national priorities; - preferential income taxation aimed at modernization, reconstruction and innovative development of production; - preferential lending to enterprises of priority industries through selective reduction of interest rates and creation of advantages in obtaining loans for investments aimed at the industrial development of new types of products and advanced technologies; - assisting innovative businesses through state investment risk insurance in high-tech industries; - setting credit limits for banks aimed at financing priority sectors of the economy, failure to comply with which would reduce their refinancing.

The main direction of state policy aimed at modernizing the technological base and sectoral structure of the economy, as the experience of developed countries shows, should be the formation of a full-fledged country national innovation system (NIS), designed to ensure the organic incorporation of innovative processes into the progressive development of the economy and society. Despite the differences in national models of national innovation system (NIS), A unifying feature for them is the leadership of the state, which provides three priorities: the development of science; development of education; development of knowledge-intensive production. The state should play an active role in determining the priorities of scientific and technological development, support for basic research, motivation of entrepreneurial activity in the innovation sphere, protection of intellectual property rights, reform of education. Stages of applied $\mathrm{R} \& \mathrm{D}$ and commercialization of innovations, it is advisable to give to private companies.

Strategic guidelines for functioning and development of the national innovation system (NIS) set priorities for scientific and technological development, which allows not only to overcome the dispersion of scarce development resources, but also to link them with the corresponding priorities in the real sector of production. In this regard, the importance of sound allocation of technological development priorities is increasing. Given this, in the US still in 1993 by Presidential decree was established the National Council for Science and Technology with the status of a federal agency, whose main purpose and function was to define and formulate in a clear form national goals and priorities for public investment in the development of science and technology. Similar state structures were created in European countries: in Germany - Technology Assessment Commission, in France - Parliamentary Directorate for Selection in Science and Technology, in Iceland - National Research Council, in Finland - Scientific Policy CouncilA resolution on the creation of European Parliament Office for the Evaluation and Selection of Priorities in the Field of Engineering Science was adopted by the European Parliament. Most countries issue «white books», which reflects the priorities of national innovation policy. Thus, for a more balanced approach to prioritizing technological development in Ukraine, which has limited resources for innovative development, it is also necessary to create a state structure that, unlike periodically created expert groups, would deal with this issue on an ongoing basis through continuous monitoring and forecasting of situation in the scientific and technical sphere and geoeconomics. Ukrainian experts have identified such areas as priorities for the period up to 2020: 1 . In the field of information and communication technologies - application software; intelligent systems for supporting the work of complex systems and complex automation of the enterprise; systems for a single telecommunications network, including the Internet, television, radio; multimedia purpose and virtual reality systems; systems for determining the position of people or objects in high precision terrain; reference systems and services using geopositioning technology; unified electronic identification documents; systems of distance education and distance health care. 2 . In the field of nanotechnology - catalysts based on artificial zeolites and other mesostructures; highly selective nanocatalysts; nanotube based catalysts for photodegradation of waste and photoanalysis of water; highly effective biocompatible materials for medical purposes; nanocomposites; intelligent materials with variable programmable properties; nanodiodes and nanolazers; microcapillary chips; biosepsor layer on microelectrodes. 3. In the field of creating newmaterials - ceramic and composite materials with critical and predetermined functional properties; protective materials for metallurgy and space technology; multifunctional optical electronic and magnetic materials; new liquid crystal materials for creating «electronic paper» displays; new types of electrode materials for non-ferrous metallurgy, hybrid inorganic-organic materials, etc. 4. In the field of living systems - new drugs that use as whole membrane proteins and receptors; means of medical diagnostics of cancer, systemic, infectious diseases; technologies of complex DNA diagnostics of hereditary dis- 
eases, assessment of the quality of products based on biochips, which allow to minimize the negative consequences of anthropogenic and natural emergencies for human health and the environment.

As a result of globalization, the national economy's competitiveness factors have been modified. From a weak set of more or less interdependent countries, the world economic community is transformed into a coherent economic system, where national societies are constituent elements of a single world economic organism, merged not only by the international division of labor, but also by their huge technological base, production and marketing base, a global financial system and a planetary information network.

The economic aspects of globalization create great opportunities for the development of new technologies, the development of the economy, the reproduction of goods that were not known to mankind, improving the quality of life, creating new jobs, obtaining information, enriching cultures of peoples of the world, free movement of goods, people, capitals and ideas, cooperation peoples and countries, on the other hand, reproduces neo-imperialism, which is a challenge to humanity and a threat to its existence, absolutizes the economic and political power of the new global monopoly corporations that have spiraled out of control nation-states, causing environmental pollution due to increased pressures when man-made disasters can cause irreversible changes in the habitats of people, increases the difference between income level destabilize peace and threaten and challenges of nation-institutional structure.

A significant threat is posed by the policy of the state, which provides real support and assistance to the major capital in the face of oligarchic circles. At the same time, the domestic producer usually does not receive the necessary support from the state, is not protected from the invasion of foreign producers, which means that it is unlikely to become competitive in the near future. Thus, the criminal factor in the economy (attempts to seize property, finances, establish bandit control over the private sector of the economy) is threatening in the country.

Economic crime is growing, taking on a new, more sophisticated latent form; used new methods based on the legal, psychological, advertising activities of professionals working with criminal offenders. In this regard, the state's efforts to overcome corruption and other illegal phenomena in the national economy are extremely relevant. The creation of a rule of law in which actions within the legal field would guarantee the protection and well-being of the entrepreneur, worker, citizen remains a promising task. The rules of law in force in society become effective only if they receive public recognition and reflect a public need, that is, the idea of a positive right that is aimed at protecting property, respecting discipline, ensuring all equal legal relations that guarantee the punishment of offenses, as well as security for business entities. The need to address internal economic security concerns does not mean reducing the importance of the geo-economic dimension of the strategy, which not only allows to take into account threats but also to exploit the opportunities opened up in the context of globalization of the global economic space in terms of access to resources and markets of other countries, the potential and competence of foreign partners, participation in the processes of transnationalization and regionalization of the innovation, production and financial spheres, breakthrough to production and distribution of the world income. In this regard, an important issue is the choice of directions of development of foreign economic activity of Ukraine. At present, most of the country's foreign economic turnover is in the share of developed countries and is reduced to the exchange of material and energy resources and products of low redistribution to complex machinery and consumer goods. This situation can not be considered satisfactory in terms of solving the problems of economic security of the country, but at the same time it objectively follows from differences in competitiveness and technological development level of the interacting countries. Overcoming the current backlog of the national economy is a complex problem that requires time and effort, so it is not possible to expect radical shifts in this issue in the medium term.

This means the need to change the priorities of Ukraine's foreign economic activity. It should not be about reducing the volume of foreign trade activity with developed countries in a form accessible to the modern economy. Moreover, it needs to be developed because, for all its shortcomings, it provides a considerable amount of foreign exchange earnings to the country and meets the needs of enterprises and the population for quality products and services. By changing the priorities of Ukraine's foreign economic activity, we mean, on the one hand, a more active complement to trade cooperation with developed countries, cooperation in the scientific and technical field, and on the other, a focus on the active development of markets for finished products in those countries where accumulated competitive advantages of domestic manufacturing enterprises are significant. Such market space is given by the countries of the former USSR, as well as the countries of Asia.

Many of them are ready to buy Ukrainian aircraft, cars, machines, light industry products today. Regarding the validity of our assertions, we should pay attention to the experience of new industrial countries in Southeast Asia, which have made a breakthrough in economic and technological development, thanks to the initial orientation on the markets of developing countries and countries with economies in transition. In this economic platform, they have subsequently been able to move from a technology borrowing policy to a technology leadership policy and a breakthrough 
in developed markets. In general, during the integration choice of strategic directions for the development of foreign economic activity of the national economy should be based on the fact that it can not be considered as an end in itself, without regard to the observance of national interests and solving internal problems of socio-economic development. Moreover, foreign economic activity should become one of the most important tools for solving domestic economic problems. As practice shows, insufficient consideration of this requirement leads to deformation of the structure of export-import activity; lack of mechanisms for attracting foreign investment in the sector, reflecting national priorities; inefficient use of resource and scientific and technical potential, and also reduces opportunities for increasing the well-being of citizens and business structures.

Conclusions. Thus, the components of the modernization potential of the anti-crisis strategy are oriented towards eliminating the effects of the economic crisis, increasing employment by creating new jobs and at the same time aiming at identifying future growth-oriented locomotives. Therefore, the urgent issue today is to develop and implement incentives for businesses of all forms of ownership. Due to inconsistent implementation and low efficiency of the state innovation-investment policy, Ukraine does not keep pace with the developed countries in technological development. As a result, the number of innovative enterprises is gradually decreasing, the development of high-tech industries is slowing down. Successful realization of the modernization potential of the anti-crisis strategy is planned to be ensured by developing partnerships between sectors of society (state: branches of government, business, public) and involvement of all stakeholders in the planning, development and implementation of this strategy (the private sector, academics, public organizations, local governments). In view of the above, as well as in the current conditions of constant expansion and expansion of globalization processes and threats to the functioning of the national economic system, the following directions of anti-crisis measures have been formed in the context of the components of new locomotives of growth: creation of system conditions for the market (improvement of the legislative base, tax support); budget support for the implementation of pilot projects, public buildings for initial market formation.

As a result, the classic market laws in the domestic innovation business only work in a modified form. Ukraine's innovation policy is implemented through mechanisms that represent concrete measures used by public authorities and society for its successful implementation. Such mechanisms are different in form and effectiveness, so it is necessary to apply them compre- hensively and systematically. Realization of Ukraine's European integration aspirations and fulfillment of the tasks of sustainable development of regions is possible only if the state-coordinated leadership of social processes, in particular innovative ones, is used. Mechanisms for the implementation of innovation policy are the following: institutional, organizational, structural, economic, communicative, information. The definition and formation of mechanisms is influenced by the type of state innovation policy and the state-selected innovation model of development of a specific strategic direction.

\section{Література}

1. Олексенко Р. І., Ортіна Г. В. Особливості інноваційно-інвестиційної політики антикризового розвитку реального сектору економіки України. Економічний вісник Запорізької державної інженерної академії. 2018. № 5 (17). С. 33-39.

2. Олексенко Р. І., Ортіна Г. В. Формування інноваційної політики реального сектору економіки як особливого напряму розвитку України. Економіка та суспільство. 2018. № 18. С. 173-180.

3. Олексенко Р. І. Правове і соціально-економічне підгрунтя ринкової економіки. Гілея: науковий вісник. 2014. Вип. 80. С. 266-270.

4. Ортіна Г. В. Напрями реалізації національної стратегії промислово-інноваційної політики. Інвестиції: практика та досвід. 2013. № 14. C. $49-52$.

5. Ортіна Г. В. Модернізація реального сектору економіки як стратегічний напрям промислової політики держави. Інвестиції: практика та досвід. 2013. № 12. С. 40-43.

\section{References}

1. Oleksenko R. I., Ortina G. V. (2018). Osoblyvosti innovatsiino-investytsiinoi polityky antykryzovoho rozvytku realnoho sektoru ekonomiky Ukrainy. Ekonomichnyi visnyk Zaporizkoi derzhavnoi inzhenernoi akademii, 5 (17), 33-39.

2. Oleksenko R. I., Ortina G. V. (2018). Formuvannia innovatsiinoi polityky realnoho sektoru ekonomiky yak osoblyvoho napriamu rozvytku Ukrainy. Ekonomika ta suspilstvo, 18, 173-180.

3. Oleksenko R. I. (2014). Pravove i sotsialnoekonomichne pidgruntia rynkovoi ekonomiky. Hileia, 80, 266-270.

4. Ortina G. V. (2013). Napriamy realizatsii natsionalnoi stratehii promyslovo-innovatsiinoi polityky. Investytsii: praktyka ta dosvid, 14, 49-52.

5. Ortina G. V. (2013). Modernizatsiia realnoho sektora ekonomiky yak stratehichnyi napriam promyslovoi polityky derzhavy. Investytsii: praktyka ta dosvid, 12, 40-43. 


\title{
ВИЗНАЧЕННЯ ФАКТОРІВ ВПЛИВУ НА ГОТЕЛЬНУ СФЕРУ УКРАЇНИ ТА ОСОБЛИВОСТІ Й ЗНАЧЕННЯ ЇЇ РИЗИКІВ
}

\begin{abstract}
Анотація. У статті досліджено зовнішні та внутрішні фактори впливу на розвиток сучасних об'єктів розміщення національної готельної сфери. Визначено, що готельний бізнес, в рамках своїх особливостей, характеризується наявністю різних ризиків. Встановлено, що від управління ризиками функціонування готельного об'єкта безпосередньо залежить результат такого функціонування.
\end{abstract}

Ключові слова: готельне господарство, готельна сфера, індустрія гостинності, ризики.

Summary. External and internal factors of influence on development of modern objects of accommodation of the national hotel sphere are investigated in the article. It is determined that the hotel business, in terms of its features, is characterized by the presence of various risks. It is determined that the result of such functioning depends directly on the management of the risks of the functioning of the hotel object.

Key words: hotel industry, hospitality industry, risks.

$$
\text { DOI : 10.33783/1977-4167-2019-46-2-32-36 }
$$

Постановка проблеми. Сфера готельного сервісу в сьогоднішніх економічних умовах відіграє найважливішу роль у задоволенні потреб суспільства. У процесі формування в Україні постіндустріального інформаційного суспільства роль сфери сервісу продовжує неухильно збільшуватися, оскільки потреби населення продовжують постійно зростати, а їх різноманітність якісно i кількісно розширюватися.

На сьогодні індустрія гостинності є однією $з$ порівняно динамічних підприємницьких сфер в Україні. Зміцнення зав'язків між регіонами, країнами і континентами, науково-технічний прогрес - усе це стимулює розвиток туризму, а відповідно і готельного бізнесу. Сучасний готельний бізнес є одними з пріоритетних видів підприємницької діяльності, який прямо впливає на ефективне вирішення соціально-економічних проблем у країні та її регіонах за рахунок забезпечення зайнятості населення. Економічна ефективність функціонування готелів безпосередньо залежить від управління цім процесом. Це зумовлено специфікою готельної діяльності, рівнем застосовуваної на підприємстві техніки, технологій, організації виробництва і праці, ефективності системи управлінської діяльності, державним управлінням, співвідношенням екстенсивних та інтенсивних факторів розвитку готельного господарства.
Одним 3 найважливіших елементів діяльності готельного господарства $є$ якість обслуговування. Від іiї рівня залежить фінансово-економічне майбутне будь-якого готельного закладу.

Аналіз останніх досліджень і публікацій. Вивченню проблем та перспектив розвитку готельного господарства приділено велику увагу вітчизняних науковців та фахівців, а саме: О. Борисової, О. Головко, Г. Круль, М. Мальської, І. Мініч, Л. Нечаюк, Н. П'ятницької, О. Шаповалової. Праці цих учених надають вичерпну інформацію щодо основ організації та розвитку готельного господарства, аналізуються чинники, що впливають на ринок готельного бізнесу в Україні. Однак питанням якості обслуговування і факторам, що мають найбільший на неї вплив, приділяється значно менше уваги і ця важлива складова функціонування готельних господарств потребує додаткових досліджень.

Мета статті - проаналізувати ключові фактори, що мають вплив на функціонування готельних господарств і якості обслуговування в них.

Виклад основного матеріалу дослідження. Сучасна гостинність - комплексна послуга, якій притаманні окремі споживчі властивості і яка формує позитивний образ об'єкта розміщення, що передбачає прояв «вторинного попиту» на такі послуги. Позитивний образ в готельній сфері

(C) І. В. Трикоз, С. С. Панчук, Л. П. Полохач, 2019

Бібліографія ДСТУ 8302:2015:

Трикоз І. В., Панчук С. С., Полохач Л. П. Визначення факторів впливу на готельну сферу України та особливості й значення їі ризиків. Вісник Бердянського університету менеджменту і бізнесу. 2019. № 2 (46). С. 32-36.

References (APA):

Trikoz, I. V., Panchuk, S. S., Polokhach, L. P (2019). Vyznachennia faktoriv vplyvu na hotelnu sferu Ukrainy ta osoblyvosti y znachennia yii ryzykiv [Introduction of factors influence on ukrainian business sphere and peculiarities of determination of risk of functioning]. Visnyk Berdianskoho universytetu menedzhmentu i biznesu, 2 (46), 32-36 (in Ukr.). 
створюється за допомогою всебічного використання матеріальних і нематеріальних ресурсів, комфортного середовища, концепції і стратегії гостинності.

Сфера гостинності традиційно визначається зовнішніми факторами (економічними, політичними, культурними і соціальними) та взаємодією спеціалізованих чинників, таких як ресурси гостинності, індустрія гостинності, професії гостинності та ін. [2, с. 36]. Важливе значення і вплив на готельну сферу мають зовнішні фактори, подані на (рис. 1).
Варто зазначити, що найбільший вплив на середовище гостинності здійснюють економічні і політичні чинники.

Економічні чинники (інфляційні процеси, стан ринку товарів і послуг, валютний курс та ін.) опосередковано впливають як на споживачів, так i на виробників сфери гостинності. Це проявляється в тому, що вони порівнюють і оцінюють можливості використання або вкладення коштів.

Політичні фактори впливають через прийняття державою відповідних законів і нормативних актів, що регулюють діяльність даної галузі.

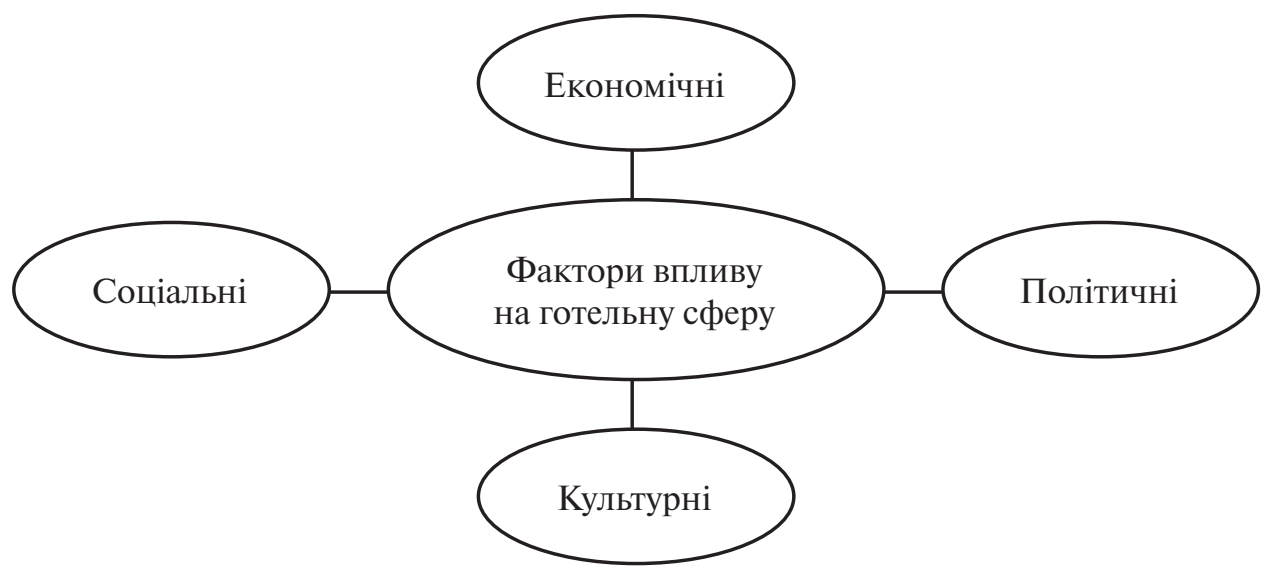

Рис. 1. Фактори впливу на готельну сферу (складено авторами на основі матеріалів [2; 5])

Культурні чинники мають безпосередній вплив на споживачів і виробників, оскільки і ті, і інші функціонують у суспільстві, яке значною мірою визначає їх поведінку. Культура визначає цінності суспільства загалом і складається 3 субкультур, які можна класифікувати за різними ознаками.

Соціальні чинники впливають на середовище гостинності через соціальний статус споживача, належність до тієї чи іншої референтної групи, яка виражає позицію людини, визначену іiі соціальною роллю і статусом.

Підтримуючи свій статус, споживач висуває до середовища гостинності певні вимоги. Диференціація суспільства за соціальним станом дозволяє визначити вплив цього фактора на поведінку споживача сфери гостинності. У кожному сучасному готелі повинні бути дуже чітко визначені принципи гостинності, обов'язки стосовно клієнтів; сформовані і чітко виконуватися фірмові стандарти обслуговування клієнта. Підтверджено, що в будь-якій справі людський фактор є детермінантною складовою прибутковості, але у сфері готельного обслуговування людський фактор набуває такого рівня, за якого саме функціонування й існування суб'єкта господарської діяльності ставитеся в пряму залежність від ефективності такого фактора. Останнім часом людському фактору в індустрії гостинності приділяють ключову увагу.
Так, наприклад, зовнішній вигляд персоналу готелю, рівень культури і вміння правильно і зі смаком одягатися, робити ділові зачіски, правильно стояти, ходити або сидіти, вести діалог або слухати клієнта - усе це в комплексі має соціально-економічний і суспільний характер [6]. Загалом, відображає внутрішній світ працівника готелю, рівень його культури, естетичні погляди, вподобання і смаки. Зовнішній вигляд персоналу готелю далеко не персональна справа кожного співробітника. Він повинен строго відповідати нормам і правилам, встановленим у всіх готелях, відповідно до міжнародних стандартів і норм обслуговування постояльців [3, с. 23].

Фірмовий одяг співробітника готелю підкреслює офіційність обслуговуючого персоналу, ідентифікує належність його до даного об'єкта розміщення, допомагає гостю легко знайти співробітника готелю, за необхідності звернутися до нього з вимогами і питаннями, з побажанням про надання тієї чи іншої послуги або допомоги в її наданні.

Готельні стандарти обслуговування клієнтів і зовнішнього вигляду співробітників належать до категорії професійних стандартів об'єктів розміщення, тобто їм повинні строго відповідати всі функціональні підрозділи співробітників саме цієї сфери послуг.

Чинні міжнародні стандарти обслуговування і зовнішнього вигляду персоналу дозволяють вивести якість обслуговування на більш високий рі- 
вень, незалежно від різних суб'єктивних причин. Критерії таких стандартів охоплюють встановлені вимоги до якості обслуговування постояльців, поведінки і якості спілкування персоналу, його зовнішнього вигляду.

Отже, індустрія гостинності є комплексним поняттям, що охоплює різні форми діяльності у сфері послуг, пов'язані з прийомом і обслуговуванням гостей з метою отримання прибутку. Вона охоплює всю сферу послуг, зокрема готельну i ресторанну справу, туристичний і транспортний бізнес, комерційне шоу та ін.

Готельний бізнес, у рамках своїх особливостей, характеризується наявністю різних ризиків. Таким чином, від управління ризиками функціонування готельного об'єкта безпосередньо залежить результат такого функціонування.

У даному випадку ризик функціонування готельного об'єкта - це якийсь невизначений вплив або умова, яка, в разі виникнення, матиме вплив (позитивний чи негативний) на об'єкТ тобто на його вартість, прибутковість, термін, зміст або якість.

Управління ризиками функціонування готельного об'єкта включає в себе процеси, пов'язані з визначенням, аналізом і реагуванням на ризики, для того, щоб підвищити ймовірність і ступінь впливу позитивних і знизити ймовірність і вплив негативних подій [6].

Необхідно зазначити, що цінність і можливість управління ризиками максимальна на самому початку функціонування готельного об'єкта і зменшується ближче до його завершення.

Вартість ризику (якщо він виникає), навпаки, у міру наближення до закінчення проєкту зростає i буде максимально відчутна на останньому етапі.

Перш, ніж почати планувати функціонування об'єкта готельної сфери, необхідно здійснити планування управління ризиками. Потім ризики необхідно ідентифікувати. Після цього з'являється можливість провести якісний і кількісний аналіз цих ризиків. Як тільки цей етап циклу пройдено, можна спланувати заходи реагування на ризики, а потім і моніторинг і контроль над ризиками.

Необхідно мати на увазі, що кількісний аналіз ризиків проводиться зазвичай тільки для великих готельних проєктів.

У такому випадку планування управління ризиками - це процес визначення дій, які необхідно здійснити залежно від виникнення тих чи інших ризиків (позитивних і негативних) при управлінні готельними об'єктами [1, с. 161].

Для створення ефективного плану управління ризиками функціонування готельного об'єкта рекомендується формувати його на підставі таких пунктів:

- методологія управління ризиками (які підходи будуть використані);
- роль та відповідальність тих хто бере участь (хто за що відповідає, хто бере участь в ідентифікації ризиків, хто контролює виконання різних заходів);

- бюджет для управління ризиками (скільки грошей закладається на ризики);

- визначення показника, як часто проводяться тренінги з управління ризиками (як і де вони проводяться);

- показники для розпізнавання настання самих ризиків;

- класифікація ризиків;

- матриця ймовірності прояву і впливу різних ризиків;

- шаблони стандартних звітів.

Ідентифікація ризиків - це виявлення (пріоритет) і документування різноманітних характеристик ризиків, які можуть істотно вплинути на функціонування готельного об'єкта. Цей процес інтерактивний і триває протягом усього життєвого циклу проєкту.

У процес виявлення ризиків варто включити всю команду готельного об'єкта, а також учасників інших подібних або залежних проєктів.

Починати ідентифікацію краще з аналізу документації (плани проєкту, дані попередніх проєктів, контракти тощо), яка може дати основні вступні.

Важливим джерелом інформації щодо можливих ризиків можуть слугувати саме опис мети, варіанти розвитку, історична й економічна інформація та ін. Для визначення ризиків можуть бути використані різні методи збору інформації, такі як мозковий штурм, метод Дельфі, опитування.

Також може проводитися аналіз контрольних списків - переліків ризиків, які можливі для даних готельних проєктів. Після завершення цієї стадії необхідно сформувати реєстр ризиків, який містить:

- список ризиків функціонування готельного об'єкта з необхідним ступенем деталізації;

- список можливих стратегій реагування на виявлені в процесі дослідження ризики.

Після того, як виявлення й оцінювання ризиків проведені, необхідно виконати їх якісне і кількісне дослідження.

Під якісним аналізом ризиків функціонування готельного об'єкта розуміється процес призначення пріоритетів виявлених ризиків шляхом комплексної оцінки ймовірності виникнення таких ризиків і ступеня їх впливу, що подалі може бути застосовано для кількісного аналізу виявлених ризиків або планування реагування на них.

Визначення ймовірності й оцінки ступеня впливу виявлених ризиків рекомендуємо здійснювати для кожного ідентифікованого ризику. При правильному оцінюванні впливу ризику визначається потенційний (позитивний або негативний) ефект, який матиме вплив на мету 
функціонування готелю (наприклад, окупність, завантаження, якість послуг та ін.).

Побудована матриця ймовірності і показники впливу будуть демонструвати комбінації ймовірностей і впливу, після чого кожному конкретному ризику присвоюється один із пріоритетів:

- низький;

- середній;

- вищий.

Оцінка оперативності реагування на ризики функціонування готельного об’єкта означає, що необхідно виявити і виділити ризики, які вимагають оперативного реагування, тобто є найбільш важливими для прийняття превентивних заходів.

Таким чином, оновлений після якісного аналізу реєстр ризиків функціонування готельного об’єкта включає в себе такі позиції:

- порівняльний рейтинговий список або пріоритетний список виділених ризиків;

- класифіковані за категоріями ризики;

- причини самих ризиків або сфери функціонування готельного об’єкта, що вимагають підвищеної уваги;

- перелік ризиків, реагування на які має бути здійснено в першу чергу;

- перелік ризиків для додаткового аналізу;

- перелік ризиків з низьким пріоритетом, але за якими здійснюється спостереження;

- тенденція ризиків (міграція).

На даному пункті варто зупинитися докладніше. Міграція ризиків - це зміна пріоритетів ризиків у ході функціонування готельного об'єкта. Вона можлива, якщо змінюються ймовірності і ступінь впливу.

Після того, як якісний аналіз ризиків проведено, здійснюється перехід до кількісного аналізу.

Цей аналіз проводиться для тих ризиків, які в процесі якісного аналізу обрані як істотні для функціонування готельного об’єкта. У процесі кількісного аналізу необхідно оцінити фінансовий ефект від настання таких ризиків, що згодом може бути корисно для прийняття рішень в умовах невизначеності.

Методи збору і представлення даних - це, наприклад, метод опитування та збору історичних даних для кількісної оцінки ймовірності настання і впливу ризиків на туристичний проєкт. Для представлення невизначених подій пропонуємо використовувати результати випробувань або можливі сценарії дерева рішень.

Найбільш поширеними методами кількісного аналізу, рекомендованими для застосування в функціонуванні готельного об’єкта, є:

- аналіз чутливості;

- аналіз очікуваної грошової вартості;

- моделювання та імітація, де розрахунок розподілу ймовірностей відбувається за допомогою методу Монте-Карло.
Таким чином, у результаті процесу кількісного аналізу ризиків з'являються:

1. Чисельна оцінка можливих результатів роботи готелю і їх імовірностей.

2. Оцінка ймовірності досягнення результату функціонування.

3. Ідентифікація найбільш важливих ризиків за допомогою визначення їх частки в загальному ризику.

4. Знаходження кращого управлінського рішення за невизначеності деяких умов і результатів.

Після проведеного кількісного аналізу ризиків рекомендуємо переходити до етапу планування реагування на ризики.

Планування реагування на ризики - це етап розроблення дій, за допомогою яких будуть реалізовані сприятливі можливості і знижені загрози. Процес так само має на увазі призначення відповідального за реагування на ризик.

Стратегії реагування на негативні ризики (загрози):

- ухиляння від ризику - зміна плану функціонування готельного об'єкта, спрямоване на усунення ризику або захист основних цілей;

- передача ризику - перенесення наслідків і управління ризиком третій стороні. За це мається на увазі сплата бонусів, страхової премії та інших винагород;

- зниження ризику - спроба знизити ймовірність настання ризику або його наслідків до прийнятного рівня.

Стратегія реагування на позитивні ризики (сприятливі можливості):

- використання ризику - усунення невідомості, пов'язаної з ризиком, через включення можливості цього ризику в план функціонування готельного об'єкта;

- спільне використання ризику - часткова або повна передача ризику третій стороні для використання до найбільшої вигоди готельного об'єкта;

- посилення ризику - зміна величини ризику шляхом збільшення його ймовірності та позитивного результату.

Після завершення планування реагування на ризики можна переходити до моніторингу і контролю над ризиками на підставі розробленої автором моделі системи управління ризиками та контролю управління готельним об'єктом.

Висновки. Існуюча готельна послуга - це показник прямої взаємодії менеджменту об’єкта розміщення і іiі безпосереднього споживача клієнта, а також індивідуальне функціонування виконавця, спрямоване на реалізацію потреби постояльця.

На якість готельної послуги впливають час i місце надання, кадровий склад, рівень кваліфіка- 
ції, психологічні особливості, навіть стан здоров’я і настрій співробітників готелю. Особисті властивості споживача також впливають на оцінку якості отриманої послуги. Зазначені відмінності послуги від товару значною мірою впливають на характер функціонування ринку готельних послуг.

Сфера гостинності традиційно визначається зовнішніми факторами (економічними, політичними, культурними і соціальними) та взаємодією спеціалізованих чинників, таких як ресурси гостинності, індустрія гостинності, професії гостинності. Варто зазначити, що найбільший вплив на середовище гостинності здійснюють економічні і політичні чинники.

Готельний бізнес, у силу своїх особливостей, характеризується наявністю різних ризиків. Таким чином, від управління ризиками функціонування готельного об’єкта безпосередньо залежить результат такого функціонування.

Напрямами подальших досліджень стане визначення ризиків функціонування об'єктів національної готельної сфери та формування заходів нівелювання загроз негативних ризиків.

\section{Література}

1. Кожухівська Р. Б. Використання міжнародного досвіду впровадження інновацій у сферу готельного бізнесу. Вісник Донецького національного університету. Сер. В. Економіка і право. 2015. Вип. 1. С. 160-164.

2. Мальська М. П. Готельний бізнес: теорія та практика : підручник. К. : Центр учбової літератури, 2012. $470 \mathrm{c}$.

3. Головко О. М., Кампов Н. С., Махлинець С. С. . Організація готельного господарства : навч. посіб. К.: Кондор, 2011. 410 с.

4. Похомчикова Е. О. Особенности инноваций в сфере услуг (на примере индустрии гостеприимства). Сервис plus. 2014. № 4 (8). С. 45-52.
5. Соловйов Д. І. Організаційно-економічні основи регулювання стандартизації та категоризації національних засобів розміщення. Вісник Бердянського університету менеджменту $i$ бізнесу. 2015. №. 4. С. 37-40.

6. Чепижко И. Риски и выгоды инвестиций в гостиничные номера. URL : https://tranio.ru/ articles/riski_i_vygody_investiciy_v_gostinichnye nomera (дата звернення: 08.04.2019).

\section{References}

1. Kozhukhivska, R. B. (2015). Vykorystannia mizhnarodnoho dosvidu vprovadzhennia innovatsii $u$ sferu hotelnoho biznesu [Using international experience in introducing innovations in the sphere of hotel business]. Visnyk Donetskoho natsionalnoho universytetu. Ser. B: Ekonomika i pravo, 1, 160-164 (in Ukr.).

2. Malska M. P. (2012). Hotelnyi biznes: teoriia ta praktyka [Hotel business: theory and practice]. Kyiv, Tsentr uchbovoi literatury, $470 \mathrm{p}$.

3. Holovko O. M. (2011). Orhanizatsiia hotelnoho hospodarstva [Organization of the hotel economy]. Kyiv, Kondor, 410 p.

4. Pokhomchikova, E. O. (2014). [Features of innovations in the service sector (by the example of the hospitality industry)]. Servis plus, 4 (8), 45-52 (in Russ.).

5. Solovyov D. I. (2015). Organizatsiyno-ekonomichni osnovi regulyuvannya standartizatsiyi ta kategorizatsiyi natsionalnih zasobiv rozmischennya [Organizational and economic bases of regulation of standardization and categorization of national accommodation facilities]. Visnyk Berdianskoho universytetu menedzhmentu i biznesu, 4, 37-40 (in Ukr.).

6. Chepizhko I. (2016). Riski $i$ vygody investitsiy v gostinichnye nomera [Risks and benefits of investing in hotel rooms]. Available at: https://tranio.ru/articles/ riski_i_vygody_investiciy_v_gostinichnye_nomera/ (accessed 08 April 2019). 


\section{ЕКОНОМІКА І УПРАВЛІННЯ ПІДПРИЕМСТВАМИ}

\section{СОЦІАЛЬНО-ЕКОНОМІЧНА БЕЗПЕКА В МЕНЕДЖМЕНТІ СУБ'СКТІВ МІКРОРІВНЯ}

Анотація. У статті обгрунтовано методологічні засади формування й підвищення соціально-економічної безпеки аграрних підприємств та вирішення практичних проблем управління ї̈ забезпеченням у їх менеджменті сучасними механізмами, засобами й інструментами.

Ключові слова: соціально-економічна безпека, управління, менеджмент, ресурси, підприємство, глобалізаційний простір.

Summary. The article substantiates the methodological foundations of forming and improving the socio-economic security of agricultural enterprises and solving practical problems of managing its provision in their management by modern mechanisms, tools and instruments.

Key words: socio-economic security, management, management, resources, enterprise, globalization space.

$$
\text { DOI : 10.33783/1977-4167-2019-46-2-37-41 }
$$

Постановка проблеми. Сучасний глобалізований світ надає великі можливості для ефективного й конкурентоспроможного розвитку аграрних підприємств та інших суб'єктів господарювання аграрної сфери економіки. Це стосується трансферту технологій, упровадження інновацій у виробничі та бізнесові процеси, їх організацію та управління, у т. ч. на основі дигіталізації; спеціалізації й диверсифікації виробництва, розвитку нових видів діяльності, інфраструктури і логістики, комунікацій; мобільності й вивільнення трудових ресурсів, особистісного зростання працівників і людського потенціалу та інтелектуального капіталу; доступності продуктів харчування й соціальної відповідальності. Поряд із цим зростають виклики й загрози їх функціонуванню та розвитку і навіть збереженню. Ідеться про недобросовісну конкуренцію й монополізацію на аграрних ринках; порушення комерційної таємниці й економічне шпигунство; небезпечні хімічні засоби захисту й меліорацій та гібридний садивний матеріал і генномодифіковану продукцію; стимулятори у тваринництві; прорахунки в управлінні, менеджменті і маркетингу; рейдерство, захоплення й поглинання; фінансові загрози й банкрутство. Також це психологічне виснаження через високі темпи життєдіяльності й погіршення мікроклімату в колективах; плинність кадрів і вивільнення працівників; зростання соціальної напруженості серед сільського населення. Ідеться й про виснаження та зменшення продуктивності природних агроресурсів, загострення екологічної ситуації в аграрних підприємствах та ін. Тому звернення до тематики досліджень соціально-економічної безпеки аграрних підприємств є надзвичайно актуальним та своєчасним. Адже саме соціально-економічна безпека є основою дотримання безпеки продовольчої основи життєдіяльності населення загалом. Вона розуміється як система попередження причин, уникнення або ж нівелювання наслідків ризиків та загроз функціонування у соціальній, виробничо-економічній, фінансовій, інноваційно-інвестиційній, екологічній, зовнішньоекономічній, інформаційній, організаційноуправлінській площинах.

Аналіз останніх досліджень і публікацій. Проблеми формування безпеки підприємств $€$ предметом досліджень багатьох відомих вітчизняних та зарубіжних науковців. Серед них Л. Мармуль, В. Геєць, М. Кизим, Т. Клебанова, О. Черняк [1;3].

Мета статті - визначення соціально-економічну безпеку як об'єкт управління в менеджменті аграрних суб'єктів господарювання мікрорівня.

Виклад основного матеріалу дослідження. Складовими соціально-економічної безпеки аграрних підприємств є сировинні та інші ресурси;

(C) В. К. Антошкін, Є. В. Кузьмін, О. М. Усата, 2019

Бібліографія ДСТУ 8302:2015:

Антошкін В. К., Кузьмін Є. В., Усата О. М. Соціально-економічна безпека в менеджменті суб'єктів мікрорівня. Вісник Бердянського університету менеджменту і бізнесу. 2019. № 2 (46). С. 37-41.

References (APA):

Antoshkin, V. K., Kuzmin, Ye. V., Usata, O. M. (2019). Sotsialno-ekonomichna bezpeka v menedzhmenti subiektiv mikrorivnia [Socio-economic security in the management of micro-level subjects]. Visnyk Berdianskoho universytetu menedzhmentu i biznesu, 2 (46), 37-41 (in Ukr.). 
основне виробництво і діяльність; соціальна інфраструктура; організація та управління; стратегії й тактика сучасного й перспективного розвитку як комерційна таємниця. Забезпечення соціальноекономічної безпеки залежить як від специфіки діяльності, так і середовища ії здійснення, а також прийнятої ділової етики на підприємстві і компетентностей відомих осіб. Також значний вплив на неї чинять рівні місцевої поселенської, галузевої, регіональної, національної безпеки, транскордонне співробітництво у випадку прикордонного положення аграрних підприємств.

Невід'ємною частиною менеджменту соціально-економічної безпеки аграрних підприємств $\epsilon$ інструменти та механізми іiі забезпечення на внутрішньогосподарському рівні, а також урахування особливостей системи засобів впливу держави (в особі законодавчих та виконавчих органів влади) на агробізнес. При цьому йдеться зокрема й про вітчизняні та іноземні великі аграрні корпорації або агрохолдинги з монопольним положенням на ринку, суб'єкти тіньової економіки).

У цій площині проблемним є те, що у глобалізованому економічному просторі, особливо в агросфері, поступово знижується ефективність деяких загальноприйнятих державних інструментів управління забезпеченням та підвищенням соціально-економічної безпеки суб'єктів господарювання. Це пояснюється величезною концентрацією ресурсів в агрохолдингах, зростанням їх капіталізації та провідним положенням на внутрішньому й зовнішньому аграрних ринках. Вони успішно лобіюють свої інтереси навіть на законодавчому рівні, та й фактично виступають як осередки організації сільських територій.

Отже, загальноприйнятим є виділення двох груп відповідних мікро- й макроекономічних інструментів прийняття управлінських рішень та їх використання у менеджменті на рівні суб'єктів господарювання агросфери.

1. Інструменти прямого впливу, які грунтуються на безпосередньому втручанні держави в економічні процеси та економічну діяльність суб'єктів агробізнесу. У межах цієї групи інструментів передбачається здійснення заходів із застосуванням інструментів адміністративного регулювання та використання бюджету в частині державних асигнувань, виплат, пільг або штрафів і санкцій. Характеристика їх змісту дієвості у національному та глобалізованому економічному просторі зводиться до визначення сутності інструментів та оцінювання їх ефективності.

Так, ідентифікація стратегічних цілей розвитку та соціально-економічної безпеки аграрних підприємств реалізується в господарському середовищі, що характеризується значним рівнем транснаціоналізації аграрної діяльності та іiі регіоналізації, а також утворенням міждержавних інтеграційних угрупувань, наявна складна багатоцільова система стратегічних цілей розвитку. Вона $€$ динамічною та визначається не тільки агробізнесом, але й іншими суб'єктами глобалізованого простору. Відповідно, ідентифікація системи стратегічних цілей розвитку аграрних підприємств та їх безпеки у менеджменті може бути здійснена у загальних рисах.

Відповідно до вимог Європейської хартії місцевого самоврядування від 15.10.1985 р., дотації органами місцевого самоврядування у регіоні не можуть призначатися для фінансування конкретних аграрних проєктів, інакше надання дотацій скасовує їх основоположну свободу проводити політику в межах власних компетенцій. Значний обсяг міжбюджетних субвенцій перетворює органи місцевого самоврядування на виконавців центрів владних рішень та мінімізує можливості для саморозвитку, що є наслідком транснаціоналізації економічної діяльності. При цьому субвенції $€$ одним з видів міжбюджетних трансфертів та, одночасно, інструментом міжбюджетних відносин i займають вагому частку в їх загальному обсязі. Визначаються як міжбюджетні трансферти для використання на певну ціль у порядку, визначеному тим органом, який прийняв рішення про надання субвенції [1].

Сутність такого інструменту, як встановлення та обмеження цін, зводиться до спрямування на формування і збереження таких цін, які б забезпечували рентабельну діяльність суб'єктів аграрного господарювання, реальність зарплати, стійкість валюти й інші соціально-економічні параметри. Разом $з$ тим, рівень цін на певні товари затверджується міждержавними органами: на вугілля й чорні метали - європейським об'єднанням вугілля і сталі; на нафту - країнами Огранізації країн-експортерів нафти (ОПЕК); на аграрну продукцію - у країнах Євросоюзу. Крім того, ефективність регулювання цін на імпортні товари значно ускладнюється інфляційними процесами та гнучкістю бівалютної корзини.

Квоти на ввезення і вивезення продукції та ліцензування операцій з експорту та імпорту інструмент, сутність якого у такому. Ліцензування операцій з експорту та імпорту - це комплекс адміністративних дій $з$ економічної політики 3 наданням дозволу на здійснення суб'єктами агросфери експорту (імпорту) товарів. У межах ліцензій можуть бути передбачені квоти. Теоретично можна встановити граничний розмір безмитного введення/виведення певних товарів на територію країни, а всі інші товари ввозяться/вивозяться на загальних засадах. Проте країни діють у глобалізованому економічному просторі, є членами Світової організації торгівлі (СОТ) та інших міжнародних об'єднань, яким притаманне уніфіковане правове поле. Відповідно, це вимагає дотримання 
єдиного митного режиму, відміни або значного зниження ввізного мита та обсягів квотування, за умови надання права експортерам виконати контрактні зобов'язання або переорієнтувати свій ринок збуту впродовж 2-х тижнів. Відтак, ефективність квотування ввізної продовольчої продукції, захисту національних агротоваровиробників та їх безпеки знижується.

Наступні інструменти - державна експертиза та встановлення державних стандартів і нормативні вимоги до якості та сертифікації технологій і продукції та ін. Оцінка їх ефективності вбачається у визначенні сутності фактичної функції окремої держави, як регулятора якості товарів та послуг, котрі обмежуються. В умовах глобалізованого економічного світу є поступова уніфікація вимог щодо якості товарів та послуг. При цьому міжнародними організаціями розроблені відповідні стандарти управління якістю ICO 9000, доповнені пізніше ICO 10000, а також пакет керівництв щодо сертифікації й акредитації якості товарів та послуг. Національні стандарти на державному, регіональному й підприємницькому рівнях якості продукції, товарів та послуг повинні бути поступово приведені у відповідність до міжнародного рівня (ICO 9000, 10000).

Варто зазначити, що окреслені інструменти надають можливості впливу держави, органів місцевого самоврядування на соціально-економічну безпеку аграрних підприємств не за рахунок додаткового матеріального стимулювання агробізнесу, а за рахунок сили державної влади. Саме тому зниження ефективності цих інструментів призводить до ослаблення засобів захисту фундаментальних економічних засад, у т. ч. соціально-економічної безпеки їх функціонування від негативного впливу зовнішніх та внутрішніх дестабілізуючих факторів.

Фактично, держава сьогодні не має достатньо дієвих засобів прямого впливу, здатних захистити слабкі фундаментальні економічні засади функціонування агроформувань, тобто їх не конкурентоспроможність. Також існує ряд проблем, які стосуються всіх етапів трансформації ідеї в інноваційну продукцію, зокрема проблема виїзду за кордон кваліфікованих кадрів, науковців, винахідників, підприємців, основними причинами якої є:

- кращі можливості для реалізації ідей за кордоном (насамперед доступ до фінансування, правовий захист, наближеність до ринків збуту, менша вартість ведення бізнесу);

- вища якість життя (безпека та верховенство права, освіта та охорона здоров'я, соціальний захист у разі потреби, інфраструктура, екологія тощо);

- творче та підприємницьке середовище, створене у найкращих світових осередках інновацій [2].
Саме тому у глобалізованому економічному просторі формується безпосередня залежність соціально-економічної безпеки аграрних підприємств від конкурентоспроможності їх товарів i послуг та власне їх конкурентоспроможності, як сукупності якостей відповідної основи, здатної забезпечити стійкий розвиток і соціально-економічну безпеку на перспективу.

2. Інструменти опосередкованого впливу на соціально-економічну безпеку аграрних підприємств. Вони грунтуються на формуванні сприятливого економічного середовища, що актуалізує діяльність суб'єктів агробізнесу у напрямі, необхідному для посилення їх соціально-економічної безпеки. У межах цієї групи інструментів передбачається вплив держави на соціально-економічні інтереси за допомогою фінансово-бюджетної, грошово-кредитної, цінової, інвестиційної та інших складових регіональної або державної аграрної політики. Сутність характеристики їх дієвості у глобалізованому економічному просторі наведено на рис. 1.

Отже, у глобалізованому економічному просторі класичні інструменти опосередкованого впливу на формування соціально-економічної безпеки аграрних підприємств мають не достатню ефективність. Разом з тим, найбільш проблемним, на нашу думку, є обмеження можливостей використання найбільш успішних, комплексних інструментів забезпечення соціально-економічної безпеки - вільних економічних зон або ВЕЗ, територій пріоритетного розвитку або ТПР. Їх створення, згідно з міжнародним та вітчизняним досвідом, дозволило б суб'єктам аграрного господарювання досягти визначних результатів у забезпеченні конкурентоспроможності, фінансово-економічної стійкості, соціально-економічної безпеки, економічного зростання [3, с. 186].

Важливим є доповнення складу та забезпечення впливу на ті або інші сторони соціально-економічної безпеки аграрних підприємств підготовки кадрів і збереження робочих місць, скорочення плинності фахівців, вирішення екологічних проблем, проблем підвищення природної продуктивності агроресурсів, створення додаткових або супутніх видів діяльності. При цьому необхідно враховувати й використовувати механізми їх співіснування у менеджменті агроутворень із мікроекономічними інструментами прийняття управлінських рішень щодо стійкого розвитку й підвищення рівня соціально-економічної безпеки - диверсифікацією виробництва, кооперацією та інтеграцією, соціальною відповідальністю та іншими важливими заходами й чинниками (рис. 2).

Соціально-економічна безпека аграрних підприємств у глобалізованому економічному про- 


\section{Вплив на соціально-економічну безпеку аграрних підприємств}

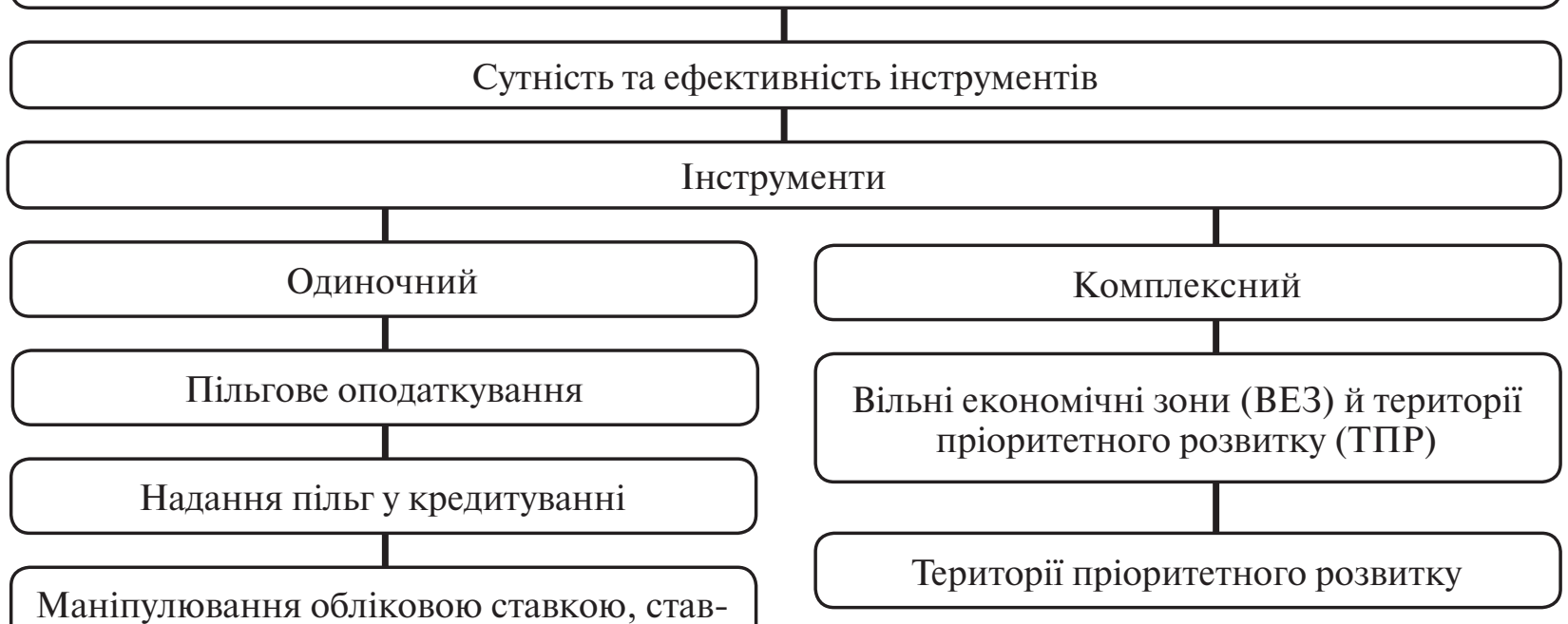

Маніпулювання обліковою ставкою, ставкою рефінансування, регулювання валютного курсу національної грошової одиниці

Митне регулювання експорту й імпорту

Рис. 1. Сутність та ефективність інструментів опосередкованого впливу на соціально-економічну безпеку аграрних підприємств (складено авторами на основі [1, 3])

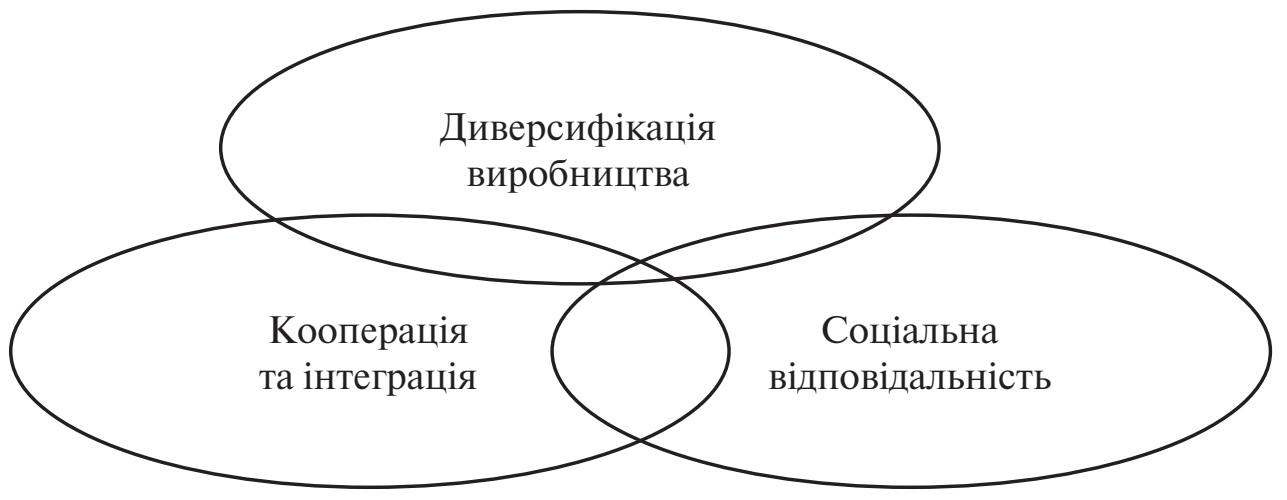

Рис. 2. Мікроекономічні інструменти прийняття управлінських рішень у менеджсменті агроутворень. (розробка автора)

сторі може забезпечуватися за допомогою інноваційних інструментів, що грунтуються на впливі держави на їх розвиток; на основі формування інноваційних технологічних та наукових парків та інноваційних кластерних структур для опосередкованого сприяння розвитку високих і надвисоких технологій та синергетичної взаємодії агротоваровиробників, спроможних забезпечити ефективну, здатну до інновацій систему їх соціально-економічної безпеки.

Вважаємо, що територіальне зближення взаємозалежних аграрних підприємств, компаній, інших учасників кластеру формує специфічне територіальне поєднання не тільки основного виробництва, а й форм розселення, інфраструктури. Отже, це дозволяє ідентифікувати його і як інструмент забезпечення соціального розвитку у т. ч., сільського способу життя, розширення мережі соціальної інфраструктури у сільських агломераціях з метою реалізації соціальних, культурних, мистецьких та інших потреб сільських жителів). Таким чином, кластери можуть стати важливим інструментом забезпечення соціальноекономічної безпеки аграрних підприємств у глобалізованому світі.

Висновки. Ураховуючи вищенаведене, необхідно зазначити, що охарактеризовані нами інноваційні інструменти достатньо ефективні у глобалізованому економічному просторі (що доведено на основі достатньо вагомого практичного досвіду багатьох країн світу). Разом 3 тим, для їх ефективного застосування необхідне вдосконалення системи управління й регулювання соціально-економічної безпеки 
аграрних підприємств на інноваційних засадах, з урахуванням динаміки їх розвитку, конкурентоспроможності й особливостей аграрних ринків.

\section{Література}

1. Мармуль Л. О., Величко Т. Г., Рогатіна Л. П. Стратегічне управління фінансовоекономічною безпекою аграрних та харчових підприємств. Вісник Бердянського університету менеджменту $і$ бізнесу. 2016. № 2 (34). С. 47-51.

2. Стратегія розвитку сфери інноваційної діяльності на період до 2030 року. URL: https:// zakon.rada.gov.ua/laws/show/526-2019-p?la.

3. Геєць В. М., Кизим М. О., Клебанова Т. С., Черняк О. І. та ін. Моделювання економічної безпеки: держава, регіон, підприємство : монографія. Харків : ВД «ІНЖЕК», 2006. 240 с.

\section{References}

1. Marmul L. O., Velichko T. G., Rogatina L. P. (2016). Stratehichne upravlinnia finansovo-ekonomichnoiu bezpekoiu ahrarnykh ta kharchovykh pidpryiemstv [Strategic management of financial and economic security of agricultural and food enterprises]. Visnik Berdyanskogo universitetu menedzhmentu i biznesu, 2 (34), 47-51.

2. Strategiya rozvitku sferi innovatsiynoï diyalnosti na period do 2030 roku [Strategy of development of the sphere of innovative activity for the period till 2030]. Retrieved from https://zakon.rada.gov.ua/laws/ show/526-2019-r?la.

3. Geets V. M., Kizim M. O., Klebanova T. S., Chernyak O. I. \& oth. (2006). Modeliuvannia ekonomichnoi bezpeky: derzhava, rehion, pidpryiemstvo [Modeling of economic security: state, region, enterprise]. Kharkiv, INZhYeK Publ., 240 p.

УДК 330.3

\section{С. С. Біляєв}

\section{ПЕРЕВАГИ ПРОЕКТНОГО ПІДХОДУ НА ПІДПРИЕМСТВІ}

Анотація. У статті розглянуто сутність і специфічні ознаки розвитку підприємства за проєктним підходом. Наведено спільні ознаки проєктів. Визначено основні класи організацій, які використовують проєктний підхід. Розкрито актуальність використання проєктного підходу в управлінні організацією.

Ключові слова: підприємство, організація, проєкт, проєктний підхід, планування, управління.

Summary. In the article, the essence and specific features of the development of an enterprise from the point of view of the projected approach are considered. Some common features of projects are given. The main classes of the organizations, using the projected approach, are determined. The urgency of using the projected approach in the management of an organization is revealed.

Key words: enterprise, organization, project, projected approach, planning, management.

$$
\text { DOI : 10.33783/1977-4167-2019-46-2-41-45 }
$$

Постановка проблеми. Нині, коли відбувається посилення глобалізації ринкового середовища, дуже сильно змінюються підходи, методи й моделі менеджменту на будь-яке підприємство для забезпечення його довготривалого успіху. Це дає підстави для наукового пошуку адекватних інструментів та управлінських рішень забезпечення сталого розвитку підприємств. На практиці однією з найпоширеніших залишається модель управління проєктами. Але питання впровадження проєктів розвитку та впорядку- вання управлінських процесів щодо їх реалізації ще не мають належної уваги вчених. Зараз цей специфічний напрям проєктної діяльності на підприємстві характеризується сегментацією наукових досліджень. Необхідність розширеного вирішення основних проблем, які впливають на формування стратегії розвитку підприємства, зумовлена потребою чіткої систематизації та розвитку теоретико-методичних основ економічної сутності й організаційно-інформаційного забезпечення процесів «еволюції» підприємств (C) С. С. Біляєв, 2019

Бібліографія ДСТУ 8302:2015:

Біляєв С. С. Переваги проєктного підходу на підприємстві. Вісник Бердянського університету менеджменту $і$ бізнесу. 2019. № 2 (46). С. 41-45.

References (APA):

Biliaiev, S. S. (2019). Perevahy proektnoho pidkhodu na pidpryiemstvi [Advantages of the project approach at the enterprise]. Visnyk Berdianskoho universytetu menedzhmentu i biznesu, 2 (46), 41-45 (in Ukr.). 
в умовах зростаючої динамічності та складності середовища господарювання.

Аналіз останніх досліджень і публікацій. Концептуальні засади теорії управління розвитком соціально-економічних систем заклали видатні українські та зарубіжні науковці: І. Адізес, Н. Афанасьєв, В. Герасимчук, Л. Грейнер, О. Ерьохіна, С. Ілляшенко, М. Кондратьєв, А. Наливайко, В. Марченко, Ю. Погорєлов, В. Пономаренко, I. Пригожин, О. Раєвнева, О. Тридід, М. ТуганБарановський, Й. Шумпетер та ін. Теоретикоприкладні аспекти проєктного управління набули подальшого розвитку в дослідженнях Р. Арчібальда, О. Баженова, В. Воропаєва, 3. Гальперіна, Р. В. Гутча, якого вважають засновником теорії управління проєктами, Д. Клеланда, В. Ліберзона, С. Ліщенка, I. Мазура, С. Нікешина, В. Рача, Л. Стакенбрука, А. Товби, Г. Ціпеса, В. Шапіра, та ін., наукові здобутки яких утворюють сучасну концепцію стратегічного управління на підприємствах [4].

Незважаючи на численні дослідження у даній галузі, процеси управління проєктами удосконалення підприємств наразі ще не набули комплексного наукового обгрунтування й залишаються слабко інтегрованими в загальну систему управління підприємством.

Мета статті - розкрити сутність і специфічні ознаки проєктів ефективного розвитку підприємства, визначити необхідність використання проєктного підходу в управлінні організацією.

Виклад основного матеріалу дослідження. Сучасні економісти стверджують, що проєкт є доволі однозначним та не викликає значних суперечностей, отже, проєкт - це одноразовий комплекс зв'язок різних заходів, який полягає у задоволенні визначеної потреби шляхом досягнення конкретних результатів при наявному матеріальному (ресурсному) забезпеченні з чітко визначеними цілями протягом заданого періоду часу [1].

За тлумачним словником Н. Вебстера, у найзагальнішому розумінні проєкт (від англ. project) - це щось, що задумується чи планується [2].

Проєкти мають як спільні, так і відмінні ознаки, серед основних можна виокремити такі:

1. Цільова спрямованість на досягнення мети. Будь-який проєкт завжди спрямований на досягнення конкретної мети. Це є головною метою проєкту, і всі зусилля, що докладаються у процесі його організації та реалізації, націлені на iii досягнення. Таке спрямування припускає, що є бажаний результат, якого можна досягти за визначений період. Для того щоб реалізація проєкту була успішною, необхідно не тільки визначити його, а й установити суттєву характеристику, зокрема умови його функціонування. Мета проєкту має бути чітко сформульованою, сумірною, обме- ження - заданими, а встановлені вимоги - здійснюваними.

2. Бюджетне обмеження. Проєктну діяльність треба спрямувати на отримання певного результату в заданий період і не використовувати без певних ресурсів (матеріальних, людських, фінансових). Тому однією з головних ознак проєкту є наявність бюджету.

3. Кількісне вимірювання. Ця ознака вказує, що витрати й прибуток від проєкту повинні бути визначені кількісно, тому що оцінка проєкту насамперед спирається на цифри.

4. Час дії. Кожний проєкт має обмеження в часі, і має дві мети:

- визначення терміну, під час якого успіх або невдача проєкту повинні бути визначені;

- оцінювання реальної цінності економічних витрат і прибутку неможливе без урахувань обмежень у часі.

5. Життєвий цикл. Проєкт розробляється, функціонує та розвивається. Існує чітка взаємозалежність різних видів діяльності за проєктом. Будь-який проєкт, незалежно від його складності та обсягу дій, необхідних для його виконання, проходить у своєму розвитку певні форми стану від задуму до реалізації.

6. Система функціонування та елементний склад проєкту, координоване між собою виконання дій. Головна суть проєктів - це визначення складності їхнього втілення в життя. Кожен проєкт потребує виконання чисельних завдань, жорстко або еластично взаємопов'язаних: деякі завдання не можуть реалізуватися, доки не завершено інші завдання. Якщо відбувається порушення синхронізації виконання різних завдань весь проєкт може опинитися під загрозою невиконання.

7. Проєкт може існувати в зовнішньому середовищі, його елементи мають великий вплив. Тому проєкт повинно аналізувати обов'язково 3 урахуванням умов середовища, у якому його здійснюють.

8. Унікальність. Проєкт - це особливий і неповторний захід. При цьому рівень унікальності може значно коливатися залежно від особливостей проєкту.

Наведемо відмінні ознаки проєктів розвитку від проєктів підприємства (табл. 1).

Діяльність як об’єкт управління у вигляді проєкту потрібно розглядати тільки тоді, коли:

- вона об'єктивно має комплексний характер і для їі ефективного управління важливим $є$ аналіз внутрішньої структури;

- досягнення цілей діяльності пов'язано 3 послідовним виконанням усіх іiі елементів;

- обмеження за часом, фінансовими, матеріальними та трудовими ресурсами впливають на процес виконання комплексу робіт; 
Відмінні ознаки проєктів розвитку підприємства

\begin{tabular}{|c|c|c|}
\hline $\begin{array}{c}\text { Аспект } \\
\text { дослідження }\end{array}$ & Проєкти підприємства & Проєкти розвитку підприємства \\
\hline $\begin{array}{l}\text { Стратегічна } \\
\text { орієнтація }\end{array}$ & $\begin{array}{c}\text { Низька кореляція зі стратегією } \\
\text { компанії }\end{array}$ & $\begin{array}{c}\text { Абсолютна залежність від стратегічного } \\
\text { бачення діяльності компанії }\end{array}$ \\
\hline $\begin{array}{c}\text { Спрямованість } \\
\text { проєктів }\end{array}$ & $\begin{array}{c}\text { Спрямовані на зовнішній ринок або об’єкти і, } \\
\text { як правило, не змінюють внутрішні процеси } \\
\text { організації }\end{array}$ & $\begin{array}{c}\text { Спрямовані як на зовнішній ринок, } \\
\text { об’єкти (ринково-позиційні), так і на } \\
\text { зміну внутрішніх процесів, ресурсів, } \\
\text { активів (ресурсно- } \\
\text { компетенційні) } \\
\end{array}$ \\
\hline $\begin{array}{l}\text { Засіб досягнення } \\
\text { цілі }\end{array}$ & Подолання проблеми функціонування & $\begin{array}{c}\text { Стратегічні зміни: трансформація } \\
\text { (реалізація інноваційної технології, } \\
\text { методології, бізнесу) або модернізація } \\
\text { (впровадження інноваційного продукту, } \\
\text { модифікація функцій) }\end{array}$ \\
\hline Результат & $\begin{array}{c}\text { Приріст обсягу продажу товарів (послуг), } \\
\text { збільшення частки компанії на ринку, розширення } \\
\text { (оновлення, скорочення) асортименту товару } \\
\text { (послуг), підвищення якості товарів (послуг) } \\
\text { компанії, зниження витрат обігу товарів (витрат на } \\
\text { послуги) компанії }\end{array}$ & $\begin{array}{c}\text { Створення і виведення на ринок нового } \\
\text { продукту, збільшення ефективності } \\
\text { використання ресурсів, комплексне } \\
\text { підвищення якості товарів (послуг), } \\
\text { розширення діяльності, партнерств, } \\
\text { підвищення рівня кваліфікації } \\
\text { персоналу, глобалізація переваг } \\
\end{array}$ \\
\hline Ефект & $\begin{array}{c}\text { Ефект обов’язково повинен бути виміряний і } \\
\text { очевидний, інакше проєкт не буде розглянутий і } \\
\text { прийнятий до реалізації }\end{array}$ & $\begin{array}{c}\text { Ефект важко виміряти, він не очевидний } \\
\text { (фактично в багатьох ситуаціях уміння } \\
\text { формулювати ефект у розрахунковому } \\
\text { вимірі визначає, буде реалізовано проєкт } \\
\text { розвитку чи ні, } \\
\text { що не завжди є виправданим заходом) }\end{array}$ \\
\hline $\begin{array}{c}\text { Критерії } \\
\text { успішності }\end{array}$ & $\begin{array}{c}\text { Дотримання термінів, бюджету, відповідність } \\
\text { запланованому результату }\end{array}$ & $\begin{array}{c}\text { Нові можливості, досягнуті вигоди, } \\
\text { виконання стратегії розвитку організації }\end{array}$ \\
\hline Обсяг/зміст & $\begin{array}{c}\text { Вузький, орієнтований на чітко визначені цілі } \\
\text { проєкту - SMART }\end{array}$ & $\begin{array}{c}\text { Широкий, залежить від стратегічних } \\
\text { цілей, змінюється залежно від очікуваноі } \\
\text { вигоди }\end{array}$ \\
\hline
\end{tabular}

- тривалість і вартість діяльності залежить від організації всього комплексу робіт.

Інший клас організацій цілком залежить від проєктів. Такі організації загалом пропонують переважно товари й послуги. У цих організаціях, проєкти фінансують найчастіше зсередини. Наприклад, у сфері виробництва (споживчих товарів, фармацевтичної продукції, інженерної продукції тощо), транспорту, зв'язку, розроблення та продажу апаратного й програмного забезпечення, а також у банківській справі, урядовій сфері, університетах, суспільних установах тощо. Як було сказано вище, такі організації залежать від проєктів, а точніше - від проєктного менеджменту.

Потрібно з'ясувати особливості проєктного менеджменту та його зв'язок з управлінням. Ці поняття $є$ різновидом одного наукового напряму - управління. Відомо такий науковий напрям, як «управління (менеджмент)», поділяється на більш дрібніші напрями: американський, японський, банківський, високоефективний, кадровий, маркетинговий, операційний, фінансовий менеджмент, менеджмент зовнішньоекономічної діяльності, освіти, торгівлі, якості, управління проєктами та державне управління тощо. Аналіз цього переліку «менеджментів» показав, що змістовна частина цих напрямів часто відрізняється одна від одної тільки на 10-30 \%. Решта - це загальні теоретичні положення та підходи до управління [5].

На сьогодні в бізнесі існує ціла низка світових тенденцій, що дають змогу говорити про застосовування проєктного підходу, тобто вагомого впливу на значення діяльності, пов’язаної із здійсненням проєктів. Головні серед них:

- перехід від регулювання й концентрації до координації та розподілу;

- скорочення життєвого циклу виробів і послуг, зокрема термінів розроблення і запуску;

- персоналізація попиту та пропозиції, продуктів і послуг;

- портфельний підхід до управління проєктами забезпечує суттєві вигоди. До їх складу можна зарахувати можливість поглянути на проєкти в глобальному контексті, що відображає стан справ загалом [3].

Якщо проаналізувати процес зміни моделі бізнесу, його починають розглядати як сукупність взаємозалежних проєктів. Такий підхід дає змогу чітко встановити іншу особливість сучасного бізнесу, коли основною стратегічною конкурентною 
перевагою стає більш гнучка стратегія поведінки в мінливому зовнішньому середовищі.

На даному етапі значно зросла необхідність проєктного управління як методу організації та управління підприємством. Усе це зумовлено об'єктивними тенденціями у всебічній реструктуризації ділового світу. Принцип концентрації виробничо-економічного потенціалу поступився місцем іншому принципу, принципу зосередження на розвиток власного потенціалу організації. Великі виробничо-господарські комплекси заміщуються гнучкими мережними структурами, серед учасників яких головним принципом є перевага використання зовнішніх ресурсів над внутрішніми. Тому виробнича діяльність дедалі більше перетворюється в комплекс робіт зі складною структурою використовуваних ресурсів, складною організаційною типологією, сильною функціональною залежністю від часу та величезною вартістю [6].

Наразі існує актуальна потреба в застосуванні нових концепцій в управлінні проєктами та розвитку бізнесу. Прикладом цього є аргументи щодо доцільності застосування концепції управління проєктами для розроблення та здійснення програм і проєктів у сфері державного управління:

- розроблення та впровадження державних програм незалежно від рівня, враховуючи їх складність, вимагає в сучасних умовах застосування інструментів проєктного менеджменту;

- управління проєктами є універсальною концепцією, що може застосовуватись для здійснення різних проєктів у всіх галузях і напрямах;

- методи та інструменти проєктного менеджменту в професійному управлінні зараз $є$ одними з найбільш досконалих, апробованих, обгрунтованих і відпрацьованих у світовій практиці, що створює сприятливі умови для запозичення передового досвіду, швидкої адаптації до національних умов і ефективного застосування.

Стосовно проєктного бізнесу проблема набуває особливо гострого характеру через деякі його особливості.

Особливості проєктного бізнесу:

- велика інтелектуальна ємність предметної галузі більшості проєктів;

- мала частка в проєктах господарської діяльності, пов'язаної з матеріальними активами;

- сильна залежність успіху проєктів від зовнішніх умов, насамперед поводження замовника;

- підвищені ризики, зокрема ризик порушення термінів і бюджету, припинення або призупинення проєкту, невдалого впровадження;

- підвищені вимоги до якості, що мають конструктивний характер, тобто характер, що об'єктивно перевіряється;

- високий ступінь індивідуалізації та важливе значення постійного контакту організації 3 клієнтом;
- висока ймовірність появи нових робіт, що раніше не виконувалися, для яких методологія, технологія і система управління повинні заново розроблюватись або удосконалюватись;

- високі вимоги до кваліфікації менеджерів і виконавців, їхня висока вартість;

- критична важливість корпоративної офісної системи, що підтримує комунікації та базу знань;

- особливий характер планування, управління, контролю й обліку;

- велика нерівномірність надходження замовлень, що ускладнює управління людськими ресурсами;

- географічна далекість клієнта;

- наявність декількох виконавців та їх географічне розмежування.

Висновки. Отже, можна стверджувати, що сутність проєктного підходу в управлінні підприємством полягає в чіткій організації, спрямованій на досягнення єдиного правильного рішення. Саме таке ствердження щодо сутності проєктного підходу призвело до застосування категорії «проєкти розвитку». Висвітлено особливості проєктного менеджменту та його зв'язок з іншими видами управління, подано основні аргументи щодо доцільності застосування концепції управління проєктами для розроблення та втілення програм і проєктів у сфері державного управління.

\section{Література}

1. Верба В. А., Загородніх О. А. Проектний аналіз : підручник. Київ : КНЕУ, 2010. 322 с.

2. Кочетков А. И. и др. Управление проектами. Санкт-Петербург : Два Три, 1993. С. 446.

3. Лашук А. М. Формування і управління портфелем проектів. Глобалізація та управління проектами у XXI столітті: матер. наук.-практ. конф., Львів, 9-10 жовт. 2013 р. / Львів. регіон. ін-т держ. упр. Нац. акад. держ. упр. при Президентові України. Львів : ЛРІДУ НАДУ, 2013. С. 100-109.

4. Мир управления проектами: основы, методы, организация, применение : [сборник] / под ред. Х. Решке, Х. Шелле. Москва : Аланс, 1994. 303 с.

5. Рач В. А., Запорожченко В. А. Роль и место управления проектами в развитии социально-экономических систем. Глобалізація та управління проектами у XXI столітmі: матер. наук.-практ. конф., Львів, 9-10 жовт. 2013 р. / Львів. регіон. ін-т держ. упр. Нац. акад. держ. упр. при Президентові України. Львів : ЛРІДУ НАДУ, 2013. С. 57-59.

6. Чикаренко I. А. Проектний підхід як один iз засобів підвищення ефективності діяльності. Теорія та практика державного управління. 2014. Вип. 9. С. 24-26.

\section{References}

1. Verba V. A., Zahorodnikh O. A. (2010). Proektnij analiz [Project analysis]. Kyiv, KNEU Publ., 322 p. 
2. Kochetkov A. I. \& oth. (1993). Upravlenie proektami [Project management]. St. Petersburg, Dva Tri Publ., P. 446.

3. Lashuk A. M. (2013). Formuvannya $i$ upravlinnya portfelem proektiv [Formation and management of project portfolio]. Globalization and Project Management in the 21st Century: Mater. Research Practice Conf., Lviv, October 9-10. 2013. Lviv, LRIDU NADU Publ., pp. 100-109.

4. Reshke H., Shelle H. (eds) (1994). Mirupravleniya proektami: osnovy, metody, organizaciya, primenenie [Project management world: basics, methods, organization, application]. Moscow, Alans Publ., 303 p.
5. Rach V. A., Zaporozhchenko V. A. (2013). Rol i mesto upravleniya proektami $v$ razvitii socialnoekonomicheskih sistem [The role and place of project management in the development of socio-economic systems]. Globalization and Project Management in the 21st Century: Mater. Research Practice Conf., Lviv, October 9-10. 2013. Lviv, LRIDU NADU Publ., pp. $57-59$.

6. Chikarenko I. A. (2014). Proektnij pidhid yak odin iz zasobiv pidvishennya efektivnosti diyalnosti [The project approach as one of the means of increasing the efficiency of the activity] Teoriya ta praktika derzhavnogo upravlinnya, 9, 24-26.

УДК 330. 341.1

A. С. Бритвенко, T. В. Запорожець, T. C. Смовж

\title{
УПРАВЛІННЯ РИЗИКАМИ ЯК ІНСТРУМЕНТ ЕКОНОМІЧНОЇ БЕЗПЕКИ ОЛІЕ-ЖИРОВИХ ПІДПРИЕМСТВ
}

\begin{abstract}
Анотащія. У статті розглянуто основні напрями інноваційно-інвестиційної діяльності оліє-жирових підприємств. Окреслено основні сегменти та способи виробництва. Наведено класифікацію підприємств оліє-жирового підкомплексу відповідно до типу продукиії, яку вони виробляють. Проаналізовано основні тенденції інноваційно-інвестиційної діяльності. Проілюстровано показники обсягів виробництва найбільших продуцентів соняшникової рафінованої і нерафінованої олій. Запропоновано шляхи розв'язання проблем відтворення та оновлення основних засобів сільського господарства в умовах обмежених фінансових можливостей сільськогосподарських виробників.
\end{abstract}

Ключові слова: інвестиції, інновації, маркетинг, оліє-жировий підкомплекс, підприємство, сегментування, харчові рослинні оліі.

Summary. The article considers the main directions of innovation and investment activity of oil and fat enterprises. The main segments and methods of production are outlined. The classification of oil and fat subcomplex enterprises according to the type of products they produce is given. The main trends of innovation and investment activity are analyzed. The indicators of production volumes of the largest producers of sunflower refined and unrefined oils are given. The ways of solving the problems of reproduction and renewal of fixed assets of agriculture in conditions of limited financial capacity of agricultural producers are proposed.

Key words: investments, innovations, marketing, oilseed fat subcomplex, enterprise, segmentation, edible vegetable oils.

$$
\text { DOI : 10.33783/1977-4167-2019-46-2-45-50 }
$$

Постановка проблеми. Оліє-жирова галузь важлива складова вітчизняного агропромислового комплексу. Ї̈ї кінцева продукція: рослинні олії, маргарин, майонез є високоякісним продуктом харчування, що користується підвище- ним попитом населення країни. Рослинні олії та маргаринова продукція використовуються як сировина на підприємствах хлібопекарської, кондитерської, харчово-концентратної та овочеконсервної галузей.

(C) А. С. Бритвєнко, Т. В. Запорожець, Т. С. Смовж, 2019

Бібліографія ДСТУ 8302:2015:

Бритвєнко А. С., Запорожець Т. В., Смовж Т. С. Управління ризиками як інструмент економічної безпеки олієжирових підприємств. Вісник Бердянського університету менеджменту і бізнесу. 2019. № 2 (46). С. 45-50.

References (APA):

Brytvienko, A. S., Zaporozhets, T. V., Smovzh T. S. (2019). Upravlinnia ryzykamy yak instrument ekonomichnoi bezpeky oliie-zhyrovykh pidpryiemstv [Risk management as a tool for the economic security of oil and fat enterprises]. Visnyk Berdianskoho universytetu menedzhmentu i biznesu, 2 (46), 45-50 (in Ukr.). 
Доцільність діяльності будь-якої економічної системи слід розглядати як процес взаємодії різних елементів, до яких належать агенти, суб'єкти та інститути, діяльність яких потребує регулювання та саморегулювання. Регулювання економіки є об'єктивним процесом, що забезпечує інтереси всіх учасників: держави, контрагентів (підприємств) й індивідів, та діє лише в результаті раціонального поєднання ринкового саморегулювання і впливу держави. Тому регулювання ринку олійних культур має враховувати особливості функціонування підприємств, сільськогосподарських підприємств, суб'єктів ринкової інфраструктури, держави та зважати на забезпечення економічної безпеки як пріоритетного завдання державної аграрної політики.

Аналіз останніх досліджень і публікацій. Теоретичною та методологічною основою досліджень сукупного впливу чинників зовнішнього та внутрішнього середовища на розвиток економічної безпеки є основні положення, викладені у роботах вітчизняних та зарубіжних фахівців, зокрема: В. А. Гарбар [2], Ю. В. Жадан [6], О. М. Полінкевич [3], І. М. Посохов [4,5,6], Т. В. Стройко [1].

Хоча у працях зазначених науковців узагальнено та систематизовано підходи до діагностування економічної безпеки підприємств, визначено механізми їх забезпечення, існують ще не вирішені питання.

Мета статті - визначити функції і принципи дії економічної безпеки оліє-жирових підприємств в умовах глобалізації.

Виклад основного матеріалу дослідження. Продукти перероблення олійної сировини (макухи і шроти) є високобілковими компонентами кормів у тваринництві, без яких неможливе створення повноцінних раціонів харчування худоби і птиці. Експерти прогнозують у найближчі $10-15$ років зростання ринку рослинної олії і цін на неї, обумовлюючи це попитом на біодизель та біоетанол, що змінюють ринкову кон'юнктуру. Серед галузевих особливостей, які впливають на формування ринку оліє-жирової продукції, доцільно виокремити такі:

- сировина, що використовується;

- концентрація і спеціалізація виробництва;

- спосіб (технологія) отримання готової продукції; зміст та характер виробництва; відносини зі споживачами продукції;

- організаційно-правові форми діяльності оліє-жирових підприємств;

- науково-технічний розвиток виробництва.

Соняшник залишається домінуючою культурою у вирощуванні і переробленні олійних культур. У загальній їх структурі в Україні у 2017 р. площі соняшнику становили відповідно $67,6 \%$, сої $-22,4 \%$, ріпаку $-8,8 \%$. Так, посівна площа соняшнику в Україні у 2017 р. становила
6033,7 тис. га, та порівняно з 2013 р. зросла на $19,4 \%$. Значно збільшилась посівна площа сої у 2017 р. порівняно з 2013 р. Цей показник становив 1999,8 тис. га, що на 46,0 \% більше, ніж у 2013 р.

Основними виробниками олійних культур є корпорації. Це стосується всіх видів олійних культур. У 2017 р. було вироблено 164824,1 тис. ц олійних культур. Господарства населення практично не займаються вирощуванням олійних. 3 184114,5 тис. ц вироблених олійних у 2017 р. лише 19290, 4 тис. ц припадало на господарства населення, з яких 84,9 \% складав соняшник. Частка інших культур коливається від 0,08 \% (льону-кудряшу) та $0,12 \%$ (насіння гірчиці), до 1,7 \% (насіння ріпаку).

Серед найбільших переробних підприємств олійних культур «БунгеУкраїна», «Кернел» та «Дельта Вілмар СНД» та ін. Основними лідерами 3 перевалки та експорту рослинної олії є термінали Іллічівська і Миколаєва, на частку яких припадає близько 90 \% іiі експорту.

Найпотужнішими терміналами з перевалки рослинних олій є ТОВ «Рісоіл-Південь» (Одеська обл., ДП МТП «Південний»), ТОВ ВКФ «Олір» (Одеська обл., м. Іллічівськ), ДП «Іллічівський морський порт» (Одеська обл., м. Іллічівськ), ТОВ «ЕВЕРІ» (м. Миколаїв), ТОВ «Термінал-Укрхарчзбутсировина» (м. Миколаїв) [1].

Основною метою створення таких об'єднань $€$ можливість здійснювати вплив на ринок готової продукції, зменшення витрат та боротьба з конкуренцією. Іншим шляхом підвищення власної ефективності, який застосовують суб'єкти підкомплексу, є формування власної сировинної бази для задоволення потреб у олійній сировині та забезпечення безперебійного і ритмічного виробництва.

Для того щоб утриматися на ринку в умовах конкуренції, оліє-жирові підприємства формують свою структуру у вигляді вертикально-інтеграційних формувань, у які крім переробних заводів входять агропромислові організації, логістичні підрозділи - транспорт, елеватори, торгові дома. Усі підприємства, як правило, є багатопрофільними. Крім олійних, займаються, наприклад, зерновими культурами. Частково діяльність диверсифікується для виробництва майонезів, кетчупів, гірчиці, мила, кормів для тварин та різних добавок. Компанії постійно покращують асортимент продукції, що випускається. До того ж розширюють лінійку продукції за рахунок кукурудзяної, оливкової та рапсової олії. Компанії розвивають власні наукові підрозділи і стежать за якістю продукції як одним 3 безумовних складових успіху на ринку.

Наразі в Україні вітчизняні підприємства оліє-жирової промисловості на відміну від зарубіжних підприємств не використовують генетично модифікованих компонентів при виробництві своєї продукції, що надає безперечну конкурент- 
ну перевагу на ринку галузі. Однак проблема загострюється тим, що вживані у світовій практиці механізми державного регулювання ринку генетично модифікованих продуктів в нашій країні практично не застосовуються. Тому для України дуже важливо удосконалювати політику в галузі регулювання ринку небезпечної продукції, у тому числі оліє-жирової галузі харчової промисловості.

Упровадження на підприємствах системи ХАССП забезпечує впевненість у безпеці продукції за рахунок запобігання або зниження до прийнятного рівня ризику виникнення небезпеки для життя і здоров'я споживачів, що особливо актуально у зв'язку з появою на ринку продуктів, що містять трансгенні складові. Система ХАССП, або Hazard Analysis and Critical Control Points (аналіз ризиків і критичні контрольні точки), є наразі основною моделлю управління якістю та безпекою харчових продуктів у промислово розвинених країнах світу. Комплекс вищевказаних заходів - сучасні методи виробництва продукції, розвиток логістики, наукові дослідження, постійне розширення асортименту, сертифікація товарів за міжнародними стандартами - утримує розглянуті підприємства в лідерах ринку оліє-жирової продукції протягом багатьох років [2].

Гарантія завантаження переробних потужностей оліє-жирової галузі забезпечила інвестиційну привабливість цієї сфери виробництва. У подальшому після набуття Україною членства у СОТ зміни в законодавстві передбачали щорічне зменшення ставки мита на $1 \%$ до $10 \%$ у кінцевому періоді, що було однією з умов СОТ. Ці заходи створили умови для переорієнтування структури експорту від сировинної до готової продовольчої продукції зі значно більшою часткою доданої вартості - олії. Це зумовило необхідність сформувати свої принципи функціонування економічної безпеки. Оліє-жирова галузь являє собою систему технологічно й економічно взаємопов'язаних галузей рослинництва, переробної промисловості, інфраструктури тощо.

Економічна безпека підприємств має властивості системи. Крім того, вона повинна діяти за такими принципами як:

- відкритість;

- нелінійність;

- динамічність;

- дисипативність;

- емерджентність;

- гомеостатичність;

- атрактивність;

- біфуркаційність;

- фрактальність.

Структура, функції, мета й процес є тими елементами, за допомогою яких можна говорити про економічну безпеку як частину системи. У будь-якій системі виникають конфлікти, які сприяють переосмисленню змін не лише у внутрішньому середовищі, але й у зовнішньому. Це формує комплексний образ цілого.

Структура є каркасом або внутрішньою опорою об'єкта, що зберігає основні ії властивості та взаємозв'язки за наявності мінливих умов. Вона складається 3 ресурсного й стейкхолдерського компонентів, що визначають життєдіяльність підприємницьких структур. Функція описує характеристики та показує набір властивих їй можливостей. Процес є наслідком діяльності системи, описує рух послідовних дій, необхідних для досягнення мети, пояснює, яким чином структура виконує функцію.

Тобто економічна безпека підприємств виконує функцію (роль) «бортового комп’ютера». Він має такі характеристики, як:

- спроможність до постійної реєстрації процесів;

- одночасний контроль елементів;

- виявлення внутрішніх загроз;

- попередження про зовнішні небезпеки.

За аналогією роль економічної безпеки підприємств є подібною. Структуру економічної безпеки оліє-жирових підприємств подано двома компонентами, а саме: ресурсним і стейкхолдерським. Ресурсний компонент складається 3 ресурсів і бізнес-процесів. Процес указує на те, що завдяки виявленню, попередженню й нейтралізації загроз можна досягти мети - забезпечення ресурсів і бізнес-процесів підприємств в умовах глобалізації.

Економічну безпеку необхідно розглядати як у статичному, так й у динамічному прояві:

1. Статичний прояв економічної безпеки як результат, досягнення ефективності діяльності.

2. Динамічний - як процес, дії, заходи, спрямовані на підвищення ефективності, підтримання та відтворення потенціалу, стійкий розвиток.

Економічна безпека включає комплекс методів, засобів та заходів захисту економічних інтересів. Аспекти, у яких розглядається економічна безпека:

- ресурсне забезпечення;

- протидія негативним зовнішнім і внутрішнім чинникам;

- пристосування до зовнішнього середовища;

- стан захищеності;

- доцільне використання ресурсів;

- досягнення поставлених цілей;

- відтворення потенціалу;

- підвищення ефективності.

Під ресурсним забезпеченням розуміється сукупність запасів, джерел коштів, можливостей, засобів і предметів праці, які контролюються корпорацією та з яких очікується отримати економічну вигоду в майбутньому. Можна виокремити такі види ресурсів, як: 
- фінансові;

- інформаційні;

- матеріальні;

- трудові.

Планування бізнес-процесів є основою будьяких підприємств. Ресурси, що входять до бізнеспроцесу як системи, перетворюються на продукти - внутрішні та зовнішні. Відповідно до цього економічна безпека оліє-жирових підприємств виконує функцію (роль) «камертона», який спроможний відтворювати подібні процеси. Економічна безпека виконує ідентичну роль.

Стейкхолдерський компонент структури економічної безпеки оліє-жирових підприємств складається 3 інтересів внутрішніх і зовнішніх учасників. Процес пояснює, що завдяки взаємному обміну вигодами та задоволенню власних інтересів можна досягти мети - гармонізації інтересів зі стейкхолдерами.

Стейкхолдери (від англ. stakeholders), або зацікавлені сторони, є фізичними та юридичними особами, які мають інтерес до діяльності підприємств, тобто певною мірою залежать від нього або можуть впливати на його діяльність.

Внутрішні стейкхолдери - суб'єкти, які перебувають у підпорядкуванні керівництву підприємств і їхня діяльність постійно спрямована на забезпечення економічної безпеки. Вони поділяються на спеціалізовані, частково спеціалізовані та неспеціалізовані суб'єкти.

Зовнішні стейкхолдери - суб'єкти, які не перебувають у підпорядкуванні керівництву підприємств. Вони мають позитивний або негативний вплив на діяльність підприємств, розподіляються на суб’єктів прямого та непрямого оточення.

Гармонізація економічних інтересів оліє-жирових підприємств з інтересами суб'єктів зовнішнього й внутрішнього середовищ постійно змінюється. Це дії щодо задоволення інтересів двох або більше взаємодіючих сторін. 3 економічного погляду гармонізацію визначають як процес взаємного узгодження, систематизацію, уніфікацію, координування, упорядкування, забезпечення взаємної відповідності економічних інтересів тощо.

Отже, економічна безпека оліє-жирових підприємств є динамічною нелінійною системою впорядкованих, взаємопов'язаних і керованих елементів (мети, структури, функцій, процесів), послідовне поєднання яких формує ресурсний та стейкхолдерський компоненти задля виявлення, попередження та нейтралізації загроз за наявних ресурсів й ефективного управління бізнес-процесами підприємств, що формує ринкову вартість клієнта.

Під керованою системою економічна безпека підприємств є бізнес-процесом, який впливає на сукупність основних, обслуговуючих та допоміжних бізнес-процесів, що використовують ресурси та забезпечують гармонізацію інтересів стейкхолдерів і стійку рівновагу підприємств [3].

На сучасному етапі розвитку економіка України i, зокрема, агропромисловий комплекс, частиною якого є оліє-жирова промисловість, функціонують у складних економічних умовах. Нестабільність кредитно-фінансової системи країни значною мірою відбивається на аграрній сфері, у тому числі і на оліє-жировому комплексі, сприяючи, своєю чергою формуванню ризиків, пов'язаних з купівельною спроможністю грошей (інфляційних ризиків), кредитних, ринкових, інвестиційних операційних ризиків, ризиків ліквідності. Разом з тим наявність різноманітних небезпечних факторів ризику компенсується високим рівнем прибутковості виробництва рослинної олії, що зумовлено досить стабільним попитом на продукцію оліє-жирових підприємств на внутрішньому ринку і наявністю значного експортного потенціалу, який має резерви зростання завдяки триваючій інтеграції України у світове господарство. Здійснення управлінського впливу на ризик передбачає зниження його рівня і контроль ризиків, тобто збільшення прибутковості та ефективності результатів діяльності підприємств оліє-жирової галузі.

В умовах ринкової економіки діяльність будьякого господарюючого суб'єкта, який здійснює підприємницьку діяльність, незалежно від форми власності та сфери діяльності, схильна до впливу безлічі факторів ризику як внутрішніх, які проявляються в процесі управління підприємством, так і зовнішніх, зумовлених впливом зовнішнього середовища на функціонування підприємства. Схильні до цього впливу і підприємства оліє-жирової галузі України, які протягом останніх років динамічно розвиваються.

Наприклад, обсяги виробництва олійних культур за останні 15 років зросли більш ніж у сім разів, при цьому виробництво насіння соняшнику збільшилося в 5,7 рази - з 2,25 млн т у 20012002 рр. до 12,9 млн т у 2016-2017 рр. обсяги виробництва й експорту соняшникової олії зросли в 5,7 і 11 разів відповідно. При цьому географія експорту української соняшникової олії розширилася на більш, ніж 30 країн.

Низький курс гривні надає додаткові переваги виробникам, які експортують соняшникову олію за кордон. Митні ризики для підприємств оліє-жирової галузі полягають у можливому непередбачуваному збільшенні рівня митних платежів та застосуванні обмежень (наприклад, квот), що чинить негативний вплив на прибутковість та ритмічність виконання експортно-імпортних контрактів.

Створення і розвиток ефективного ризикменеджменту на вітчизняних оліє-жирових підприємствах гальмується проблемами, серед яких 
можна виділити недостатній рівень кваліфікації менеджерів і персоналу до управління ризиками, недосконалість вхідної інформації і методів ії оброблення, відсутність навичок роботи зі стандартами з управління ризиками $[4,5]$.

Найбільш небезпечними видами ризиків в умовах, що склалися, є природно-кліматичні, ринкові, фінансові (кредитні, операційні, валютні, інвестиційні), митні та юридичні ризики. Природно-кліматичні ризики в країні виникають через несприятливі природно-кліматичні умови, що знижує врожайність олійних культур i призводить до подорожчання сировини для виробників. Ринкові ризики для підприємства проявляються у збільшенні випуску конкурентами аналогічної продукції або продукції кращої якості, вихід на ринок нових виробників, застосування ними агресивної маркетингової і цінової політики.

Фінансові ризики у вітчизняних умовах виявляються настільки часто, що вже починають сприйматися як дійсність. Ціна на кредитні ресурси і до фінансової кризи була набагато вище середньосвітових показників, а протягом останніх 10 років вона призводить до нерентабельності використання цього виду фінансування для більшості підприємств галузі. Це ж підтверджує й icнування валютних ризиків, що чудово демонструє динаміка валютних курсів в Україні (зниження курсу гривні до світових валют у більш ніж п’ять разів з 2008 по 2018 р.).

Юридичні ризики можуть мати різну природу, зокрема це зміна законодавства, порушення авторських прав на торговельні марки, недостатня юридична захищеність бізнесу в Україні, корумпованість судової системи та ін.

Удосконалення управління ризиками на підприємствах оліє-жирової галузі передбачає створення відповідного організаційного забезпечення, наявність методичного та інформаційного забезпечення, а також кваліфікованого персоналу, що володіє спеціальними знаннями і навичками 3 управління ризиками. 3 метою підвищення ефективності управління ризиками на оліє-жировому підприємстві запропоновано провести певні реорганізаційні заходи.

По-перше, виправданим буде створення служби економічної та інформаційної безпеки, яка адміністративно підпорядковуватиметься директору з безпеки, а функціонально - директору з економіки та фінансів. Основними функціями цієї служби будуть:

- визначення переліку інформації з статусом комерційної таємниці, а також переліку осіб, які несуть відповідальність за їі збереження;

- захист інформації на підприємстві;

- установка певних регламентів і правил інформаційної безпеки;
— контроль і перевірка всіх підрозділів підприємства щодо виконання цих правил.

По-друге, доцільно сформувати в організаційній структурі спеціальний підрозділ - відділ управління ризиками, очолюваний керівником відділу з управління ризиками, який буде займатися виключно проблемами управління ризиками, і координувати діяльність всіх підрозділів зі збору і аналізу інформації з метою регулювання ризикових подій і забезпечення компенсації можливих втрат і збитків. Відділ управління ризиками повинен підпорядкуватися директору з економіки та фінансів, збирати й аналізувати інформацію 3 усіх підрозділів і служб підприємства. Функції керівника підрозділу з управління ризиками на підприємстві оліє-жирової галузі можуть бути досить широкими. У його веденні повинні перебувати питання забезпечення безпеки і контролю ризиків. Він буде формувати організаційну структуру відділу і системи управління ризиком на підприємстві, а також розробляти основні положення та інструкції, пов’язані з цією діяльністю.

3 метою формування більш ефективної організаційної структури управління ризиками на підприємстві доцільно введення елементів матричної організаційної структури, яка являє собою складну структуру, орієнтовану на інноваціі, висуває особливі вимоги до персоналу і рівня координації різних робіт на підприємстві. Основним завданням керівника відділу управління ризиками і його підрозділів повинні бути розроблення стратегії і принципів управління ризиком на підприємстві, викладених у внутрішніх нормативних документах. Основними функціями відділу управління ризиками на підприємстві оліє-жирової промисловості є:

- виявлення ризику;

- збір, аналіз і статистичне оброблення інформації;

- розроблення превентивних і коригувальних дій;

- розроблення альтернативних варіантів прийняття рішень;

- надання інформації про можливі ризики керівництву;

- моніторинг і контроль рівня ризику на підприємстві.

По-третє, для отримання синергетичного ефекту від реалізації процесів управління ризиками необхідно удосконалювати взаємодію між підрозділами підприємства. Для цього в кожному підрозділі підприємства необхідно визначити співробітника, відповідального за збір і аналіз інформації для відділу управління ризиками і прописати ці функції в його посадових інструкціях. [6]. Функціонально він буде підпорядкуватися начальнику відділу з управління ризиками, а адміністративно - безпосередньо начальнику підрозділу, в якому працює. 
Висновки. Ринок оліє-жирової продукції в Україні наразі є одним із найперспективніших секторів аграрного виробництва. Оліє-жирова продукція користується попитом як на внутрішньому, так і на світовому ринках, де Україна займає позиції лідера.

Економічна безпека оліє-жирових підприємств є складною системою, що формується 3 двох системоутворювальних елементів: керованої та системи керування. У результаті їх взаємодії формуються загальносистемні якості, тобто ознаки, властиві системі загалом та, зокрема, кожній із них. Властивості керуючої та керованої систем визначають їхнє місце у внутрішній конфігурації системи та реалізовуються в ії̈ функціях.

\section{Література}

1. Стройко Т. В. Експортна логістика олієжирової галузі України та необхідність їі державної підтримки. Економіка і регіон. 2014. №6 (49). C. 4 .

2. Гарбар В. А. Вплив галузевих особливостей на формування ринку оліє-жирової продукції в Україні. Економіка та управління національним господарством. 2018. Вип. 16. URL : http:// economyandsociety.in.ua/journal/16_ukr/18.pdf.

3. Полінкевич О. М. Економічна безпека підприємств як керованої системи в умовах неоіндустріалізації. Економічний часопис Східноєвропейського національного університету ім. Лесі Украӥнки. 2018. № 2 (14). С. 14-17.

4. Посохов І. М. Дослідження методів оцінки ризиків підприємств. Свропейський вектор економічного розвитку. 2017. № 2 (15). С. 211-217.

5. Посохов I. М. Аналіз досліджень зарубіжних наукових шкіл ризик-менеджменту. Маркетинг $i$ менеджммент інновацій. 2013. №4. С. 164-172.

6. Посохов И. М., Жадан Ю. В. Особенности управления рисками на предприятиях масложировой отрасли. Європейський вектор модернізаціі економіки: креативність, прозорість та сталий розвиток. 2018. URL : http://repository.kpi.kharkov.
ua/bitstream/KhPI-Press/35937/1/Posokhov_ Osobennosti_upravleniya_2018.pdf.

\section{References}

1. Stroiko T. (2014). Eksportna lohistyka oliiezhyrovoi haluzi Ukrainy ta neobkhidnist yii derzhavnoi pidtrymky [Export logistics of oil and fat industry of Ukraine and the need for its state support]. Ekonomika i rehion, 6 (49), 4.

2. Harbar V. (2018). Vplyv haluzevykh osoblyvostei na formuvannia rynku oliie-zhyrovoi produktsii $v$ Ukraini. [Influence of branch features on formation of the market of oil and fat production in Ukraine]. Ekonomika ta upravlinnia natsionalnym hospodarstvom, 16. Retrieved from http://economyandsociety.in.ua/ journal/16_ukr/18.pdf.

3. Polinkevych O. (2018). Ekonomichna bezpeka pidpryiemstv yak kerovanoi systemy $v$ umovakh neoindustrializatsii. [Economic security of enterprises as a managed system in the conditions of neo-industrialization]. Ekonomichnyi chasopys Skhidnoievropeiskoho natsionalnoho universytetu im. Lesi Ukrainky, 2 (14), 14-17.

4. Posokhov I. (2017). Doslidzhennia metodiv otsinky ryzykiv pidpryiemstv [Research of methods of risk assessment of enterprises]. Yevropeiskyi vektor ekonomichnoho rozvytku, 2 (15), 211-217.

5. Posokhov I. (2013). Analiz doslidzhen zarubizhnykh naukovykh shkil ryzyk-menedzhmentu. [Analysis of research of foreign scientific schools of risk management]. Marketing and innovation management. 4, 164-172.

6. Posokhov Y. M., Zhadan Yu. V. (2018). Osobennosty upravlenyia ryskamy na predpryiatyiakh maslozhyrovoi otrasly. Yevropeiskyi vektor modernizatsii ekonomiky: kreatyvnist, prozorist ta stalyi rozvytok. [Peculiarities of risk management at enterprises of oil and fat industry]. European vector of economic modernization: creativity, transparency and sustainable development. Retrieved from http://repository.kpi. kharkov.ua/bitstream/KhPI-Press/35937/1/Posokhov_Osobennosti_upravleniya_2018.pdf]. 


\title{
ТЕОРЕТИКО-МЕТОДОЛОГІЧНІ ОСНОВИ АНТИКРИЗОВОГО УПРАВЛІННЯ ПІДПРИЕМСТВОМ
}

\begin{abstract}
Анотація. У статті здійснено грунтовний та комплексний теоретико-методологічний аналіз антикризового управління підприємством. Вивчено підходи вітчизняних учених стосовно розуміння та тлумачення сутності та змісту поняття «антикризове управління підприємством». Охарактеризовано сучасні методи, які використовуються в антикризовому управлінні на підприємстві.

Ключові слова: антикризове управління підприємством, методи антикризового управління, тактичні методи антикризового управління, стратегічні методи антикризового управління, антикризове бізнес-планування.
\end{abstract}

Summary. The article provides a thorough and comprehensive theoretical and methodological analysis of the crisis management of the enterprise. The approaches of national scientists to understanding and interpreting the essence and content of the concept of «crisis management of enterprise» are studied. Modern classifications of methods used in crisis management at the enterprise are characterized.

Key words: crisis management of the enterprise, methods of crisis management, tactical methods of crisis management, strategic methods of crisis management.

$$
\text { DOI : 10.33783/1977-4167-2019-46-2-51-55 }
$$

Постановка проблеми. Сучасні реалії економічного стану України змушують керівників підприємств часто приймати управлінські рішення в умовах невизначеності та труднощів. На жаль, політична та фінансова нестабільність у нашій державі призводить до того, що підприємницькій діяльності можуть загрожувати кризові ситуації, кінцевим результатом яких може стати банкрутство підприємства або взагалі його ліквідація. Тому виникає нагальна потреба в активізації теоретико-методологічних досліджень у сфері антикризового управління. Це, на наш погляд, приведе до удосконалення та появи нових підходів, моделей, методів у системі антикризового менеджменту, застосування яких на практиці дасть позитивний результат у процесі виходу підприємства з кризового стану.

Аналіз останніх досліджень і публікацій. Теоретико-методологічні аспекти антикризового управління підприємством висвітлюють у своїх працях такі вітчизняні вчені, як: Л. О. Лігоненко, І. О. Бланк, А. С. Бурий, Д. С. Мацеха, Л. С. Ситник, А. М. Штангрет, О. В. Коваленко, В. М. Маховка та ін. Проте незважаючи на низку теоретико-методологічних досліджень стосовно антикризового управління підприємством, дана проблематика потребує подальшого наукового обгрунтування, насамперед це стосується систематизації основних підходів щодо тлумачення сутності поняття «антикризове управління підприємством», удосконалення класифікацій методів антикризового управління (наприклад стратегічних та тактичних методів) тощо.

Мета статті - виконати теоретико-методологічний аналіз антикризового управління на підприємстві в сучасних умовах трансформації української економіки.

Виклад основного матеріалу дослідження. Антикризове управління є важливою складовою менеджменту на підприємстві, адже забезпечує його діяльність в умовах нестабільності та кризи. Використовуючи тлумачення поняття «управління», запропоноване провідними іноземними дослідниками у сфері менеджменту М. Месконом, М. Альбертом, Ф. Хедоурі [1, с. 38], можна 3 точки зору функціонального підходу надати таке визначення антикризового управління на підприємстві - це процес планування, організації, мотивації і контролю, необхідний для того, щоб сформулювати і досягти цілей підприємства під час попереднього запобігання або реального подолання кризових явищ в його діяльності.

(C) Ю. Ю. Гурбик, М. В. Сальнікова, 2019

Бібліографія ДСТУ 8302:2015:

Гурбик Ю. Ю., Сальнікова М. В. Теоретико-методологічні основи антикризового управління підприємством. Вісник Бердянського університету менеджменту і бізнесу. 2019. № 2 (46). С. 51-55.

References (APA):

Hurbyk, Yu. Iu., Salnikova, M. V. (2019). Teoretyko-metodolohichni osnovy antykryzovoho upravlinnia pidpryiemstvom [Theoretical and methodological basis of crisis management of the enterprise]. Visnyk Berdianskoho universytetu menedzhmentu i biznesu, 2 (46), 51-55 (in Ukr.). 
Необхідно зазначити, що аналіз наукової літератури дає підстави стверджувати, що поняття «антикризове управління підприємством» $є$ неоднозначним і теоретично дискусійним у вітчизняній науці. Праці українських учених, присвячені теоретико-методологічним питанням антикризового управління підприємством, показують, що вони використовують для тлумачення досліджуваного поняття різні підходи (процесний, системний та ін.) (табл. 1).

Тлумачення поняття «антикризове управління підприємством» вітчизняними науковцями

\begin{tabular}{|c|c|}
\hline Автор, джерело & Визначення поняття \\
\hline Л. О. Лігоненко & $\begin{array}{l}\text { Постійно організоване управління, націлене на найбільш оперативне виявлення ознак кри- } \\
\text { зового стану та створення відповідних передумов для його своєчасного подолання з метою } \\
\text { забезпечення відновлення життєздатності окремого підприємства, недопущення ситуації } \\
\text { його банкрутства [2, с. 57]. }\end{array}$ \\
\hline Л. С. Ситник & $\begin{array}{l}\text { Система управління спрямована на вирішення завдань інтенсивного розвитку підприємства } \\
\text { завдяки мобілізації та інтенсифікації всіх ресурсів на противагу екстенсивному розвитку [3, } \\
\text { с. 25]. }\end{array}$ \\
\hline I. О. Бланк & $\begin{array}{l}\text { Постійно діючий процес виявлення ознак кризових явищ та реалізація генерального плану } \\
\text { недопущення поширення кризових явищ і стагнації розвитку підприємства, який здійсню- } \\
\text { ється протягом усього періоду його функціонування [4, с. 7]. }\end{array}$ \\
\hline А. М. Штангрет & $\begin{array}{l}\text { Система управління підприємством, спрямована на завчасне виявлення можливих кризових } \\
\text { ситуацій, розроблення заходів протидії, швидкого реагування на будь-які зміни у зовнішньо- } \\
\text { му і внутрішньому середовищах, що становлять загрозу для існування підприємства [5, с. 99]. }\end{array}$ \\
\hline О. О. Шапуров & $\begin{array}{l}\text { Сукупність заходів спрямованих на виявлення латентних процесів та реальних загроз та за- } \\
\text { стосування до них, відповідних механізмів стабілізації з метою усунення явищ стагнації та } \\
\text { статичних процесів [6, с. 35]. }\end{array}$ \\
\hline $\begin{array}{l}\text { С. А. Бурий, } \\
\text { Д. С. Мацеха }\end{array}$ & $\begin{array}{l}\text { Система постійних системних дій менеджерів, спрямованих на всі елементи організації з ме- } \\
\text { тою швидкого і вчасного реагування на можливі зовнішні та внутрішні загрози при ефектив- } \\
\text { ному функціонуванні чи розвитку організації [7, с. 21]. }\end{array}$ \\
\hline $\begin{array}{l}\text { С. К. Рамазанов, } \\
\text { О. П. Степаненко, } \\
\text { Л. А. Тимашова }\end{array}$ & $\begin{array}{l}\text { Система управління підприємством, яка має комплексний, системний характер і спрямо- } \\
\text { вана на запобігання та усунення несприятливих для діяльності підприємства явищ за допо- } \\
\text { могою розроблення і реалізації на підприємстві спеціальних заходів, які мають стратегічний } \\
\text { характер і дозволяють усунути тимчасові перешкоди, зберегти і примножити ринкові позиції } \\
{[8, \text { с. 22]. }}\end{array}$ \\
\hline О. О. Мельниченко & $\begin{array}{l}\text { Система управління, спрямована насамперед на раннє виявлення суперечностей підприєм- } \\
\text { ства із зовнішнім середовищем або у його внутрішньому середовищі з огляду на окремі біз- } \\
\text { нес-процеси підприємства з метою запобігання кризовим явищам на підприємстві; у разі ви- } \\
\text { никнення імовірності настання кризового стану - на переорганізацію виконання окремих } \\
\text { бізнес-процесів відповідно до поточних умов господарювання; при виникненні кризового } \\
\text { стану - на розроблення механізму виходу з кризи, що передбачатиме здійснення відповід- } \\
\text { них інструментів та процедур та глибоке переосмислення принципів діяльності підприєм- } \\
\text { ства. [9, с. 159]. }\end{array}$ \\
\hline $\begin{array}{l}\text { Й. С. Завадський, } \\
\text { Т. В. Осовська, } \\
\text { О. О. Юшкевич }\end{array}$ & $\begin{array}{l}\text { Діяльність менеджменту фірми, спрямована на подолання гострих проблем підприємства, } \\
\text { що накопичилися внаслідок поганого управління [10, с. 14]. }\end{array}$ \\
\hline
\end{tabular}

Слід зазначити, що серед дослідників немає чіткої позиції і щодо періоду, коли повинно відбуватися антикризове управління на підприємстві. Ми погоджуємося з науковою думкою А. О. Глєбової та Т. О. Конзерської, які проаналізувавши роботи українських та зарубіжних учених стосовно антикризового управління на підприємстві, визначають три підходи до розуміння сутності «антикризове управління підприємством» $[11$, с. 35$]$ :

- передкризове управління (превентивне);

- управління в умовах кризи (фактичне);

- управління процесами виходу з кризи.

Ми вважаємо, що кожен із цих підходів є правильним, адже відображає певний етап здійснення антикризового управління на підприємстві. Зрозуміло, що виявлення кризових проблем та симпто- мів до настання реальної кризи на підприємстві є дуже важливим етапом антикризового управління, адже передбачає залучення значно менших зусиль та ресурсів (фінансових, управлінських, матеріальних тощо), ніж це було би потрібно, коли підприємство вже фактично опинилося у кризовому стані. Проте слід зауважити, що навіть найдосконаліша система превентивного антикризового управління, повністю не гарантує, того що підприємство не опиниться у кризовому стані, а тому антикризове управління підприємством повинно враховувати різні можливі ситуації, у яких може перебувати підприємство і бути готовим не тільки здійснювати профілактичні заходи, а й усувати та долати реальні кризові явища, а також управляти процесами щодо виходу з кризи підприємства. 
Антикризове управління підприємством є особливим видом менеджменту, адже використовує власні специфічні методи, які в умовах стабільного ефективного розвитку на підприємстві не застосовуються в системі загального менеджменту. Так Л. О. Лігоненко визначаючи антикризове управління підприємством інтелектуальним видом управління, відмічає, що однією з відмітних його особливостей $€$ «використання специфічного (нестандартного і навіть неприємного в нормальних умовах) управлінського інструментарію, тобто засобів та прийомів управлінського впливу [12, с. 163].

Ми вважаємо, що методи посідають вагоме місце в теорії та методології антикризового управління, адже це сукупність засобів, прийомів та інструментарію, за допомогою яких виконуються визначені завдання та досягається поставлена мета антикризового управління, реалізовується антикризова політика на підприємстві.
Аналіз класифікацій методів антикризового управління підприємством показав, що серед вітчизняних учених поширеним є поділ їх на дві групи - стратегічні та тактичні методи.

Застосування тактичних методів спрямовано на швидке покращення фінансових показників, наприклад підприємства, подолання наслідків кризи. Проте у більшості випадків цих методів недостатньо для усунення основної причини кризового стану - неефективної системи управління й необхідно використання заходів більш тривалої діï. Результати застосування стратегічних методів підприємство відчуває, як правило, не одразу, проте вони змінюють сутність бізнесу, його якісні характеристики, такі як конкурентоспроможність, інвестиційна привабливість, інноваційність тощо [13, с. 63].

Слід зауважити, що серед вітчизняних науковців є певні розбіжності щодо віднесення видів методів до стратегічної та тактичної груп (табл. 2)

Таблиия 2

Класифікація методів антикризового управління підприємством

\begin{tabular}{|c|c|c|}
\hline Автор, джерело & Стратегічні методи & Тактичні методи \\
\hline О. В. Коваленко [14, с. 111] & $\begin{array}{l}\text { Ліквідація } \\
\text { Створення нових підприємств } \\
\text { Регуляризація } \\
\text { Модернізація } \\
\text { Злиття } \\
\text { Диверсифікація } \\
\text { Реструктуризація } \\
\text { Реінжиніринг } \\
\end{array}$ & $\begin{array}{l}\text { Санація } \\
\text { Даунсайзинг } \\
\text { Банкрутство }\end{array}$ \\
\hline В. М. Маховка $[15$, с. 221] & \begin{tabular}{|l|} 
Санація \\
Банкрутство \\
Реструктуризація
\end{tabular} & \begin{tabular}{|l} 
Діагностика \\
Моніторинг \\
Бенчмаркінг \\
Даутсайзинг \\
Аутсорсинг \\
Контролінг \\
Аудит бізнес-процесів \\
\end{tabular} \\
\hline А. Ю. Погребняк [16, с. 307] & $\begin{array}{l}\text { Диверсифікація } \\
\text { Регуляризація } \\
\text { Реінжиніринг } \\
\text { Реструктуризація } \\
\text { Злиття } \\
\text { Ліквідація }\end{array}$ & $\begin{array}{l}\text { Даунсайзинг } \\
\text { Санація } \\
\text { Моніторинг } \\
\text { Контролінг }\end{array}$ \\
\hline
\end{tabular}

Як ми бачимо з даних табл. 2, розподіл методів антикризового управління підприємством на стратегічні та тактичні потребує подальшого наукового осмислення та узгодження.

Окрім вище перелічених методів антикризового управління підприємством, на нашу думку важливим і ефективним, а також пристосованим до умов сучасної вітчизняної ринкової економіки є бізнес-планування. Необхідно зазначити, що багато науковців у своїх дослідженнях розглядають бізнес-планування як процес, який здійснюється в нормальних, стабільних умовах функціонування підприємства, насамперед для залучення інвестицій. I не приділяють належної уваги стосовно застосування процесу бізнес-планування під час діяльності підприємства в умовах кризи, який сприятиме пошуку інших механізмів залучення фінансових потоків, головні з-поміж яких - інвестування, кредитування, створення відповідних фондів тощо [17, с. 111].

Антикризове бізнес-планування є важливим видом стратегічних методів антикризового управління, який має низку притаманних для нього особливостей, адже розробляється в умовах нестабільної діяльності підприємства. Серед них можна виокремити: оперативність складання; стислість термінів планування; розділи антикризового бізнес-плану, які повинні характеризуватися чіткістю, конкретністю та цілеспрямованістю; розроблення та реалізація антикризового бізнес-плану, здійснювані в умовах нестачі внутрішніх фінансових ресурсів підприємства, несприятливого соці- 
ально-психологічного клімату серед персоналу та в інших кризових ситуаціях [18, с. 85].

Висновки. Отже, антикризове управління $€$ важливою складовою системи менеджменту підприємства, адже забезпечує запобігання та подолання негараздів та криз, які виникають в його діяльності. Також антикризове управління підприємством використовує особливий набір методів, тому що застосування більшості з них не притаманне в нормальних та стабільних умовах функціонування та розвитку підприємства (санація, банкрутство, ліквідація, даунсайзинг та ін.).

Визначено основні підходи тлумачення сутності поняття «антикризове управління підприємством», які відрізняються тим, що в них акцентується увага на тому коли повинно здійснюватися антикризове управління на підприємстві, а саме до настання кризи (превентивне антикризове управління), під час протікання кризових явищ (фактичне антикризове управління) чи на етапі виведення підприємства 3 кризового стану. У статті обгрунтовано думку, що не потрібно виділяти з них пріоритетний чи самий раціональний підхід, адже вважаємо, що система антикризового управління підприємством повинна обов'язково передбачати заходи і щодо прогнозування та запобігання симптомів кризи на підприємстві, так і заходи реального подолання і виведення його 3 кризового стану.

Аналіз класифікацій методів антикризового управління підприємством виявив, що серед вітчизняних науковців поширеним є підхід, коли методи поділяються на дві групи - стратегічні та тактичні. На наш погляд основною проблемою даної класифікації є те, що однакові види методів антикризового управління одні вітчизняні науковці відносять до тактичних методів, а інші до стратегічних методів. Тому в українських наукових колах необхідне подальше узгодження та удосконалення методологічного інструментарію антикризового управління на підприємстві.

Під час наукового дослідження обгрунтовується пропозиція щодо включення до стратегічних методів антикризового управління підприємством ще одного важливого методу антикризового бізнес-планування.

\section{Література}

1. Мескон М. Х., Альберт М., Хедоури Ф. Основы менеджмента. Москва : Дело, $1998.800 \mathrm{c}$.

2. Лігоненко Л. О. Антикризове управління підприємством: теоретико-методологічні засади та практичний інструментарій : монографія. Київ : Ніка-Центр, 2000. 390 с.

3. Ситник Л. С. Організаційно-економічний механізм антикризового управління підприємством. Донецьк : ІЕП НАН України, 2000. 503 с.
4. Бланк И. А. Антикризисное финансовое управление предприятием. Киев : Эльга ; НикаЦентр, 2006. 672 с.

5. Штангрет А. М. Окремі аспекти використання проактивного антикризового управління на поліграфічних підприємствах. Наукові записки. 2007. № 1 (11). С. 98-103.

6. Шапуров О. О. Формування концепції антикризового управління на основні взаємодії системи латентних процесів та системи діагностики явних загроз. Інвестиції: практика та досвід. 2013. № 23. С. 35-40.

7. Бурий С. А., Мацеха Д. С. Антикризове управління та управлінські рішення - проблеми підприємств малого бізнесу : монографія. Хмельницький : Тріада-М, 2006. 93 с.

8. Рамазанов С. К., Степаненко О. П., Тимашова Л. А. Методи антикризового управління : монографія. Луганськ : Вид-во СНУ ім. В. Даля, 2004. 192 c.

9. Мельниченко О. О. Сутність антикризового управління підприємством у сучасних умовах господарювання. Економічний аналіз. 2015. № 2. T. 21. С. $157-162$.

10. Завадський Й. С., Осовська Т. В., Юшкевич О. О. Економічний словник. Київ : Кондор, 2006. 356 c.

11. Глєбова А. О., Конзерська Т. О. Формування системи антикризового управління на підприємстві. Молодий вчений. 2015. №11 (26). Ч. 2. C. $35-40$.

12. Лігоненко Л. О. Антикризове управління підприємством в умовах економіки знань та інтелектуалізації менеджменту. Економічний форум. 2016. № 1. C. 161-170.

13. Кульчій I. О. Антикризове управління : навчальний посібник. Полтава : ПолтНТУ, 2016. $120 \mathrm{c}$.

14. Коваленко О. В., Галь С. В. Методи антикризового управління підприємством. Економічний вісник Запорізької державної інженерної академії. 2014. Вип. 8. С. 107-114.

15. Маховка В. М. Процес, методи та функції антикризового управління на підприємстві. Науковий вісник Полтавського університету економіки i торгівлі. 2012. № 1 (52). С. 219-225.

16. Погребняк А. Ю. Сутність складових елементів механізму антикризового управління на промисловому підприємстві. Економічний вісник Національного технічного університету України «Київський політехнічний інститут». 2015. № 12. C. 300-310.

17. Марченко О. А. Механізми залучення фінансово-інвестиційних ресурсів у розвиток туристичної галузі на регіональному рівні та особливості управління ними. Науковий вісник Херсонського державного університету. Серія економічні науки. 2015. Вип. 15. Ч. 2. С. 110-113. 
18. Гурбик Ю. Ю., Біляєв С. С., Сальнікова М. В. Бізнес-планування як ефективний метод антикризового управління компанією: теоретико-методологічний аспект. Причорноморські економічні студіi. 2018. Вип. 32. С. 83-87.

\section{References}

1. Meskon, M. Kh., Albert, M., Khedoury, F. (1998). Osnovy menedzhmenta [Fundamentals of Management]. Moscow, Delo (in Rus.).

2. Lihonenko L. O. (2000). Antykryzove upravlinnia pidpryiemstvom: teoretyko metodolohichni zasady ta praktychnyi instrumentarii [Crisis management of the enterprise: theoretical and methodological principles and practical tools]. Kyiv, Nyka-Tsentr (in Ukr.).

3. Sytnyk, L. S. (2000) Orhanizatsiino-ekonomichnyi mekhanizm antykryzovoho upravlinnia pidpryiemstvom [Organizational and economic mechanism of enterprise crisis management]. Donetsk, IEP NAN Ukrainy (in Ukr.).

4. Blank Y. A. (2006). Antykryzysnoe fynansovoe upravlenye predpryiatyem [Crisis financial management of the enterprise.]. Kyev, Nyka-Tsentr. (in Ukr.).

5. Shtanhret, A. M. (2007) Okremi aspekty vykorystannia proaktyvnoho antykryzovoho upravlinnia na polihrafichnykh pidpryiemstvakh [Some aspects of the use of proactive crisis management in printing companies]. Naukovi zapysky, 1 (11), 98-103 (in Ukr.).

6. Shapurov, O. O. (2013) Formuvannia kontseptsii antykryzovoho upravlinnia na osnovni vzaiemodii systemy latentnykh protsesiv ta systemy diahnostyky yavnykh zahroz [Formation of the concept of crisis management on the basic interactions of the system of latent processes and the system of diagnosis of obvious threats]. Investytsii: praktyka ta dosvid, 23, 35-40 (in Ukr.).

7. Buryi, S. A., Matsekha, D. S. (2006). Antykryzove upravlinnia ta upravlinski rishennia - problemy pidpryiemstv maloho biznesu [Crisis management and management solutions - problems of small business enterprises]. Khmelnytskyi: Triada-M (in Ukr.).

8. Ramazanov, S. K., Stepanenko, O. P., Tymashova, L. A. (2004). Metody antykryzovoho upravlinnia [Methods of crisis management]. Luhansk : Vyd-vo SNU im. V. Dalia (in Ukr.).

9. Melnychenko, O. O. (2015) Sutnist antykryzovoho upravlinnia pidpryiemstvom u suchasnykh umovakh hospodariuvannia [The essence of crisis management of the enterprise in modern conditions of management]. Ekonomichnyi analiz, 2, 157-162 (in Ukr.).
10. Zavadskyi, Y. S., Osovska, T. V., Yushkevych, O. O. (2006). Ekonomichnyi slovnyk [Economic Dictionary]. Kyiv, Kondor. (in Ukr.).

11. Hliebova, A. O., Konzerska, T. O. (2015). Formuvannia systemy antykryzovoho upravlinnia na pidpryiemstvi [Formation of crisis management system at the enterprise]. Molodyi vchenyi, 11 (26), 35-40 (in Ukr.).

12. Lihonenko, L. O. (2016). Antykryzove upravlinnia pidpryiemstvom $v$ umovakh ekonomiky znan ta intelektualizatsii menedzhmentu [Crisis management of the enterprise in the conditions of knowledge economy and management intellectualization]. Ekonomichnyi forum, 1, 161-170 (in Ukr.).

13. Kulchii, I. O. (2016). Antykryzove upravlinnia [Crisis management]. Poltava, PoltNTU (in Ukr.).

14. Kovalenko, O. V., Hal, S. V. (2014). Metody antykryzovoho upravlinnia pidpryiemstvom [Methods of crisis management of the enterprise]. Ekonomichnyi visnyk Zaporizkoi derzhavnoi inzhenernoi akademii: zbirnyk naukovykh prats, 8, 107-114 (in Ukr.).

15. Makhovka, V. M. (2012). Protses, metody ta funktsii antykryzovoho upravlinnia na pidpryiemstvi [Process, methods and functions of crisis management at the enterprise]. Naukovyi visnyk Poltavskoho universytetu ekonomiky $i$ torhivli, 1 (52), 219-225 (in Ukr.).

16. Pohrebniak, A. Yu. (2015). Sutnist skladovykh elementiv mekhanizmu antykryzovoho upravlinnia na promyslovomu pidpryiemstvi [The essence of the components of the mechanism of anti-crisis management in an industrial enterprise] Ekonomichnyi visnyk Natsionalnoho tekhnichnoho universytetu Ukrainy «Kyivskyi politekhnichnyi instytut», 12, 300-310 (in Ukr.).

17. Marchenko, O. A. (2015). Mekhanizmy zaluchennia finansovo-investytsiinykh resursiv u rozvytok turystychnoi haluzi na rehionalnomu rivni ta osoblyvosti upravlinnia nymy [Mechanisms of attraction of financial and investment resources in the development of tourism industry at the regional level and peculiarities of their management]. Naukovyi visnyk Khersonskoho derzhavnoho universytetu. Seriia ekonomichni nauky, 15, 110-113 (in Ukr.).

18. Hurbyk, Yu. Yu., Biliaiev, S. S., Salnikova, M. V. (2018). Biznes-planuvannia yak efektyvnyi metod antykryzovoho upravlinnia kompaniieiu: teoretykometodolohichnyi aspekt [Business planning as an effective method of crisis management company: theoretical and methodological aspect] Prychornomorski ekonomichni studii, 32, 83-87 (in Ukr.). 


\title{
ПРОБЛЕМИ І ПЕРСПЕКТИВИ ВІДТВОРЕННЯ ВИРОБНИЧО-РЕСУРСНОГО ПОТЕНЦІАЛУ МАЛИХ АГРАРНИХ ПІДПРИЕМСТВ І ДОМОГОСПОДАРСТВ НАСЕЛЕННЯ
}

\begin{abstract}
Анотація. У статті виявлені проблеми та тенденції використання й відтворення виробничо-ресурсного потенціалу агроформувань, особливо малих та середніх, а також домогосподарств населення. Визначено, що методологічні переваги забезпечення цих процесів мають нормативний підхід, що забезпечує енергоощадність та ресурсозбереження. Обгрунтовано вплив виробничо-ресурсного потенціалу та його раціонального ресурсокористування на конкурентоспроможність аграрних підприємств і домогосподарств населення. Визначено необхідність удосконалення організаційно-економічних механізмів управління розвитком виробничо-ресурсного потенціалу з метою підвищення ефективності його використання й забезпечення розширеного відтворення.

Ключові слова: аграрні підприємства, домогосподарства, агрохолдинги, потенціал, проблеми, перспективи, відтворення, нормативні засади, управління, механізм, підвищення, удосконалення.
\end{abstract}

Summary. The article reveals the problems and trends in the use and reproduction of production and resource potential of agricultural formations, especially small and medium-sized, as well as households. It is determined that the methodological advantages of ensuring these processes has a regulatory approach that provides energy and resource conservation. The influence of production and resource potential and its rational resource use on the competitiveness of agricultural enterprises and households is substantiated. The necessity of improvement of organizational and economic mechanisms of management of development of production and resource potential for the purpose of increase of efficiency of its use and maintenance of the expanded reproduction is defined.

Key words: agricultural enterprises, households, agricultural holdings, potential, problems, prospects, reproduction, regulatory framework, management, mechanism, increase, improvement.

$$
\text { DOI : 10.33783/1977-4167-2019-46-2-56-60 }
$$

Постановка проблеми. Ефективне функціонування малих аграрних підприємств, домогосподарств населення є практично неможливим без якісного й економічно обгрунтованого розвитку та відтворення його виробничо-ресурсного потенціалу. У сучасних умовах, коли великі агроформування по типу агрохолдингів та агропромислових корпорацій з високим рівнем капіталізації відтворили та значно модернізували основні засоби, бізнесові виробничо-економічні процеси, використовують інноваційні технології виробництва, значна частка домогосподарств, малих та середніх аграрних підприємств знаходиться у нестійкому, ризикованому або кризовому фінансово-економічному стані.

Тому ї стратегічною метою є одержання максимальних прибутків за мінімальних витрат ресурсів. При цьому вони часто втрачають можливості здійснення навіть простого відтворення свого виробничо-ресурсного потенціалу. Гострий дефіцит виробничих, насамперед, фінансовоінвестиційних та інформаційних, ресурсів та їх структурна розбалансованість призводять до зниження темпів економічного розвитку сектору малих аграрних підприємств і домогосподарств, потенційні можливості якого використовуються не повною мірою. Це гальмує вирішення існуючих економічних, соціальних та екологічних проблем сільських територій, зайнятості, підвищення доходів та рівня життя сільського населення.

Аналіз останніх досліджень і публікацій. Проблеми формування в кожному аграрному підприємстві, незалежно від форм власності та організації виробництва раціонального за своїм розміром та складом виробничо-ресурсного потенціалу і ефективного його використання та розширеного відтворення, належать до найбільш актуальних. Тому вони досліджуються значною кількістю науковців, серед яких: В. Андрійчук, О. Бугуцький, Ю. В. Василенко, Ю. Гринчук, М. Ігнатенко,

(C) М. М. Ігнатенко, 2019

Бібліографія ДСТУ 8302:2015:

Ігнатенко М. М. Проблеми і перспективи відтворення виробничо-ресурсного потенціалу малих аграрних підприємств і домогосподарств населення. Вісник Бердянського університету менеджменту і бізнесу. 2019. № 2 (46). C. $56-60$.

References (APA):

Ihnatenko, M. M. (2019). Problemy i perspektyvy vidtvorennia vyrobnycho-resursnoho potentsialu malykh ahrarnykh pidpryiemstv $i$ domohospodarstv naselennia [Problems and prospects of reproduction of production and resource potential of small agricultural enterprises and households]. Visnyk Berdianskoho universytetu menedzhmentu i biznesu, 2 (46), 56-60 (in Ukr.). 
М. Кісіль, Л. Мармуль, Б. Пасхавер, І. Романюк, В. Россоха та ін. Проте необхідно визнати, що, незважаючи на значну кількість наукових досліджень, низка важливих питань потребує поглибленого опрацювання. Ідеться про перспективи раціонального використання та відтворення виробничо-ресурсного потенціалу малих агроформувань і домогосподарств населення на нормативних засадах, вплив цих процесів на їх ефективність, конкурентоспроможність та досягнення інших (підвищення зайнятості, диверсифікація діяльності, збереження довкілля) цілей функціонування.

Мета статті - виявити проблеми та в обгрунтувати перспектив використання та відтворення виробничо-ресурсного потенціалу малих i середніх аграрних підприємств та домогосподарств населення, у т. ч. за допомогою фінансово-економічних механізмів і нормативних методів удосконалення та підвищення ефективності.

Виклад основного матеріалу дослідження Прогресивні зміни в аграрному секторі економіки визначаються, переважно, темпами розвитку і нарощення виробничо-ресурсного потенціалу, впровадженням інновацій, інвестиційним забезпеченням підприємств та домогосподарств населення. Однією 3 найбільш важливих і актуальних проблем, з якими нині стикаються переважно малі та середні агроформування, є ефективне розміщення ресурсів 3 метою отримання найбільших прибутків, забезпечення фінансово-економічної стійкості та конкурентоспроможності.

Конкурентоспроможність аграрних підприємств і домогосподарств населення визначається їх здатністю виробляти якісну та екологічно чисту продукцію, яка має попит серед споживачів, а також забезпечує отримання прибутків, достатніх для організації розширеного відтворення. Основою формування такої здатності є виробничо-ресурсний потенціал суб’єктів діяльності [1, с. 189]. Здійснені дослідження вказують на низький рівень використання та відтворення виробничого потенціалу, що й зумовлює ризики та нестійкий характер їх функціонування.

Зокрема, в Україні, яка має найкращі сільськогосподарські угіддя в Європі та посідає чільне місце у світі за площею ріллі - 41,7 млн га (близько 69,1 \% території), продуктивність сільського господарства нижча від рівня загальноєвропейських і загальносвітових стандартів через недостатнє відтворення природних ресурсів, особливо родючості грунтів, використання вторинної техніки, повільне впровадження інноваційних технологій.

Спад ресурсозабезпечення означає зменшення використання мінеральних і органічних добрив, засобів захисту рослин, досягнень селек- ції рослин і тварин, кормовиробництва, біотехнологій. Незважаючи на значні позитивні зміни ресурсного забезпечення великого агробізнесу, обсяги й рівень наукових розробок, їх ціна, терміни та механізми впровадження у виробництво не задовольняють потреби інших аграрних підприємств. Структурна перебудова економіки країни, попри численні програми, заяви урядовців та лозунги, досі не грунтується на інноваційній основі [2, с. 75]. Наукомісткість промислового виробництва не перевищує $0,3 \%$, а сільського господарства ще менша, що спричиняє деструктивні процеси в галузі й негативно впливає на конкурентоспроможність її суб'єктів.

Отже, стратегічні напрями зростання й забезпечення конкурентоспроможності підприємств аграрного сектору повинні грунтуватися, передусім, на управлінні формуванням їх виробничо-ресурсного потенціалу. Зростання конкурентоспроможності наблизить виробників до досягнення мети їх функціонування, неодмінною умовою чого є збільшення обсягів виробництва сільськогосподарської продукції та покращення iii якості. Здійснені дослідження засвідчили, що наявний виробничо-ресурсний потенціал аграрних підприємств має змогу забезпечити істотне збільшення виробництва сільськогосподарської продукції.

При цьому виробничо-ресурсний потенціал аграрних підприємств слід розглядати як сукупність взаємопов'язаних ресурсів (земельних, матеріально-технічних, трудових, фінансово-економічних), які можуть використовуватись не тільки у виробничому процесі, але й у фінансовій, соціальній, екологічній та інших сферах діяльності господарств. Проблема ресурсного забезпечення аграрних підприємств ускладнюється тим, що через низку причин, серед яких інвестиційна криза, нестабільність цінового механізму та фінансової політики, аграрний сектор не є інвестиційно привабливим. Оновлення матеріально-технічної бази відбувається на недостатньому рівні. Відтак, зменшується можливість інтенсифікації виробництва, не дотримуються строки виконання сільськогосподарських робіт, знижуються показники валового збору і, відповідно, рентабельності агроформувань [3, с. 128].

Виробничо-ресурсний потенціал аграрних підприємств повинен являти собою не лише набір окремих видів ресурсів, а єдину систему взаємопов'язаних оптимальних за кількістю та якістю ресурсних складових. Тому для розширеного відтворення виробничо-ресурсного потенціалу необхідно ефективно управляти процесом його формування та використання. Ефективність застосування кожного виду ресурсів, через свої специфічні особливості, оцінюється за допомогою сукупності показників. Головними критері- 
ями ефективності використання виробничо-ресурсного потенціалу є зростання валової продукції і прибутку. Інтегрованим критерієм ефективності використання виробничо-ресурсного потенціалу повинна виступати окупність витрат.

Стратегічне управління виробничо-ресурсним потенціалом аграрних підприємств - це діяльність підприємства, спрямована на системне управління всіма компонентами виробничо-ресурсного потенціалу з метою реалізації перспективних напрямів його розвитку та підвищення ефективності використання [4, с. 14]. Сучасний менеджмент вимагає формування нових систем управління ресурсами, що забезпечують регулювання рівня їх витрат для досягнення господарюючим суб’єктом певної мети.

Система управління витратами має вирішити завдання, яке полягає у виборі такого варіанта величини витрат, за якого, з одного боку, відбувається економія ресурсів, а з іншого - досягається запланований результат. Будь-яке управління витратами повинне грунтуватися на розумінні причин їх походження. Високої результативності управління можна досягти лише за активного впровадження нормативного методу планування й обліку витрат.

Ефективне управління виробничо-ресурсним потенціалом господарюючого суб’єкта в сучасних умовах повинно базуватися на зіставленні фактичних даних з обгрунтованими нормативами, оскільки зіставлення даних звітного періоду з даними попереднього періоду не може вважатися достатньою підставою для прийняття ефективних управлінських рішень. Інструментом їх прийняття має бути об’єктивна інформація. Останніми роками питання нормування ресурсів аграрних підприємств втратили свою актуальність і, природно, витіснилися з економічної роботи. Невідповідність нормативної бази умовам господарювання $є$ одним з факторів, що перешкоджають утвердженню практики управління витратами [5, с. 486]. Тому одним із пріоритетних напрямів ефективного використання виробничо-ресурсного потенціалу є формування нормативної бази, що полягає в коригуванні, розробленні і систематизації нормативів.

Нормативна база повинна формуватися індивідуально для кожного аграрного підприємства 3 урахуванням конкретних виробничоекономічних умов його господарювання. Вона має включати нормативи оцінки величини елементів виробничо-ресурсного потенціалу, раціонального формування за складом і структурою. Впровадження інноваційних процесів ресурсокористування потребує відповідного професійнокваліфікаційного рівня підготовки працівників. Тому особливе значення слід приділяти використанню різних форм перенавчання й підвищення кваліфікації, зокрема, проведення на базі кращих регіональних аграрних підприємств науковопрактичних конференцій і семінарів.

Варто також більше уваги приділяти цілеспрямованому управлінню процесом формування ефективного кадрового потенціалу. Він, зокрема, полягає в розробленні бакалаврських та магістерських програм навчання, соціально-економічних програм відповідальності агробізнесу з метою залучення й утримання молодих перспективних спеціалістів. Основними напрямами формування системи ефективного управління використанням виробничо-ресурсного потенціалу є: забезпечення раціонального використання земельних, водних та інших природних ресурсів, а також основних матеріальних засобів.

Також це застосування енерго- та ресурсоощадних технологій; ефективне використання трудових ресурсів; забезпечення стабільності формування й ефективності використання внутрішніх і зовнішніх фінансових ресурсів; розвиток інноваційних процесів і впровадження їхніх результатів у забезпечення екологізації, інтенсифікації аграрного виробництва та продовольчої безпеки країни та регіонів [6, с. 278].

За рахунок біологізації й екологізації процесів інтенсифікації можна досягти значного спаду витрат ресурсів на одиницю сільськогосподарської та продовольчої продукції. Для розроблення й успішного впровадження цієї системи необхідно досягти високого рівня інформаційно-аналітичного забезпечення управління. Впровадження нових інформаційних технологій і застосування сучасної комп'ютерної техніки - необхідна умова ефективного управління виробничо-ресурсним потенціалом. Систему інформаційного забезпечення необхідно спрямувати на ефективне управління виробництвом в умовах його самофінансування.

Для удосконалення механізмів управління процесами розширеного відтворення виробничо-ресурсного потенціалу малих аграрних підприємств і домогосподарств населення доцільно виокремити такі складові: природні ресурси, що беруть участь у створенні сільськогосподарської продукції та потребують спеціальних програм відтворення; споживчий потенціал продовольчого ринку, що забезпечує соціально-економічну та продовольчу безпеку країни; інтелектуальний потенціал аграрних підприємств, який потребує активного розвитку [7, с. 58].

На особливу увагу заслуговує підприємницький потенціал аграрних підприємств і домогосподарств, який потребує нових форм кооперування, інтегрування та державної підтримки; організаційно-економічний потенціал аграрних підприємств, який має орієнтуватися на впровадження нових методів управління 3 урахуванням осо- 
бливостей підгалузей сільського господарства, розвитку управлінських та інформаційних технологій; соціально-економічний потенціал, який визначається відносинами власності, розвитком соціальної інфраструктури сільських територій, перевагами сільського способу життя.

Такий підхід дозволить чітко визначити показники відтворення ресурсів малих аграрних підприємств і домогосподарств населення відповідно до державної аграрної політики, пріоритети якої пов’язані з напрямами відтворення виробничо-ресурсного потенціалу: забезпеченням у сільськогосподарському виробництві за допомогою системи державних організаційно-правових заходів прибутку на авансований капітал, включно 3 вартістю земельних ресурсів, не нижче середнього рівня по національному господарству - відтворення виробничих та земельних ресурсів.

Важливим є створення умов для реалізації та захисту прав селян на землю, формування ринкових земельних відносин, охорону земель - відтворення трудових та земельних ресурсів, захист соціальних інтересів селян та розвитку сільських територій; посилення соціального захисту сільського населення, встановлення заробітної плати та пенсійного забезпечення працівників сільського господарства не нижче середнього рівня в галузях економіки держави; створення рівних умов для функціонування різних організаційно-правових форм господарювання в аграрному секторі, які сприяють гармонізації інтересів власників та найманих працівників - захист соціальних інтересів селян та розвитку сільських територій [8, с. 52].

3 цією метою здійснюються розроблення і запровадження державних та регіональних програм комплексного розвитку сільських територій, удосконалення державної підтримки розвитку підприємництва 3 метою розв'язання проблеми зайнятості сільського населення; державна підтримка розвитку конкурентоспроможного сільськогосподарського виробництва на основі кооперації та інтеграції - розвиток виробничо-ресурсного потенціалу; запровадження сучасних механізмів і методів формування прозорого ринку сільськогосподарської продукції, продовольства, капіталу, виробничих ресурсів та робочої сили; державна підтримка суб'єктів аграрного сектору шляхом концентрації державних ресурсів на пріоритетних напрямах розвитку.

Це дозволяє забезпечити формування сприятливої цінової, фінансово-кредитної, страхової, податкової та бюджетної політики - розвиток управління фінансовими ресурсами; забезпечення раціональних внутрішньогалузевих і міжгалузевих економічних відносин; створення сприятливих умов для реалізації експортного потенціалу аграрних підприємств - розвиток зовнішньоеко- номічної діяльності; державну підтримку підготовки, перепідготовки і підвищення кваліфікації спеціалістів, виконання наукових досліджень для аграрних підприємств - розвиток трудових ресурсів.

Тим самим буде досягнуто створення умов для закріплення у сільській місцевості кваліфікованих спеціалістів сільського господарства, освіти, культури, охорони здоров'я та побутового обслуговування - соціально-економічний розвиток села [9, с. 55]. Буде здійснена державна підтримка сільськогосподарських товаровиробників, які використовують меліоровані землі, особливо щодо утримання внутрішньогосподарських меліоративних систем та оплати електроенергії, що витрачається для подачі води для поливу.

Висновки. Важливою умовою раціонального використання виробничо-ресурсного потенціалу та підвищення конкурентоспроможності малого і середнього агробізнесу на цій підставі є удосконалення організаційно-економічних механізмів у діяльності домогосподарств, малих і середніх аграрних підприємств щодо процесів формування і використання ресурсів. Це сприяло б їх розширеному відтворенню, забезпеченню продовольчої безпеки країни, розвитку сільських територій та досягненню фінансово-економічної стійкості окремих виробничих структур, формуванню середнього класу на селі.

\section{Література}

1. Андрійчук В. Г. Ефективність діяльності аграрних підприємств: теорія, методика, аналіз. K. : KHEУ, 2005. 292 c.

2. Саблук П. Т. Розвиток земельних відносин в Україні. К. : ННЦ ІАЕ, 2006. 396 с.

3. Ignatenko M. M., Novak N. P. Development of regional programs for the development of agrarian enterprises with organic production on the basis of the European and international experience. Baltic Journal of Economic Studies. Vol. 4, No. 4. 2018. C. 126-133.

4. Романюк I. А. Особливості відтворювального процесу в аграрному секторі. Агросвіт. 2016. № 11. C. 12-15.

5. Кісіль М. І., Кожем’якіна М. Ю., Канцуров О. О., Дишлюк О. А. Відтворення і нагромадження аграрного капіталу. Агропромисловий комплекс України: стан, тенденцї та перспективи розвитку : інформаційно-аналітичний збірник. 2009. Вип. 6. 764 с.

6. Ігнатенко М. М. Стратегії та механізми управління розвитком соціальної відповідальності суб'єктів господарювання аграрної сфери економіки : монографія. Херсон : Айлант, 2015. 470 с.

7. Россоха В. В. Теоретико-методичні засади формування, розвитку та оцінювання виробничого потенціалу сільськогосподарського підприємства. К. : ННЦ IAE, 2009. 94 с. 
8. Ignatenko, M. M., Marmul, L. O. Productionecological and socio-economic prospects of reproduction and use of bioenergy potential of agrarian enterprises. Science and practice: an innovative approach : collection of scientific articles. Les Editions L'Originale, Paris, France, 2017. C. 50-54.

9. Онищенко О. Сільськогосподарські підприємства після реорганізації: ресурсозабезпеченість, виробничі затрати, продуктивність. Економіка України. 2010. №12. С. 52-63.

\section{References}

1. Andriychuk, V. H. (2005). Efektyvnist diyalnosti ahrarnykh pidpryyemstv: teoriya, metodyka, analiz [Efficiency of agricultural enterprises: theory, methodology, analysis]. Kyiv, KNEU (in Ukr.).

2. Sabluk, P. T. (2006). Rozvytok zemelnykh vidnosyn v Ukrayini [Development of land relations in Ukraine]. Kyiv, NNTS IAE (in Ukr.).

3. Ihnatenko, M. M. \& Novak, N. P. (2018). Development of regional programs for the development of agrarian enterprises with organic production on the basis of the European and international experience. Baltic Journal of Economic Studies, 4 (4), 126-133 (in Engl.).

4. Romaniuk, I. A. (2016). Osoblyvosti vidtvoryuvalnoho protsesu $\mathrm{v}$ ahrarnomu sector [Features of the reproduction process in the agricultural sector]. Ahrosvit, 11, 12-15 (in Ukr.).

5. Kisil, M. I., Kozhemyakina, M. Yu., Kantsurov, O. O. \& Dyshlyuk, O. A. (2009). Vidtvorennya $i$ nahromadzhennya ahrarnoho kapitalu.
Ahropromyslovyy kompleks Ukrayiny: stan, tendentsiyi ta perspektyvy rozvytku [Reproduction and accumulation of agricultural capital. Agro-industrial complex of Ukraine: state, trends and prospects of development]. Informatsiyno-analitychnyy zbirnyk, 6, 764 p. (in Ukr.).

6. Ihnatenko, M. M. (2015). Stratehiyi ta mekhanizmy upravlinnya rozvytkom sotsialnoyi vidpovidalnosti subyektiv hospodaryuvannya ahrarnoyi sfery ekonomiky [Strategies and mechanisms for managing the development of social responsibility of economic entities in the agricultural sector of the economy]. Kherson, Aylant (in Ukr.).

7. Rossokha, V. V. (2009). Teoretyko-metodychni zasady formuvannya, rozvytku ta otsinyuvannya vyrobnychoho potentsialu silskohospodarskoho pidpryyemstva [Theoretical and methodological basis of formation, development and evaluation of the production potential of agricultural enterprises]. Kyiv, NNTS IAE (in Ukr.).

8. Ihnatenko, M. M. \& Marmul, L. O. (2017). Production-ecological and socio-economic prospects of reproduction and use of bioenergy potential of agrarian enterprises. Science and practice: an innovative approach. Les Editions L'Originale, Paris, France, 50-54 (in Ukr.).

9. Onyshchenko, O. (2010). Silskohospodarski pidpryyemstva pislya reorhanizatsiyi: resursozabezpechenist, vyrobnychi zatraty, produktyvnist [Agricultural enterprises after reorganization: resource availability, production costs, productivity.economy of Ukraine]. Ekonomika Ukrayiny, 12, 52-63 (in Ukr.). 
УДК 330. 341.1

\title{
А. А. Клименко, \\ Х. Д. Гуренко, \\ С. Ю. Качковський
}

\section{ВПЛИВ СТРОКІВ СІВБИ ТА ШИРИНИ МІЖРЯДДЯ НА ВРОЖАЙНІСТЬ СОНЯШНИКУ}

\begin{abstract}
Анотація. У статті розглянуто результати досліджень з питань особливостей підвищення економічної ефективності, розвитку та формування врожаїв соняшнику залежно від елементів технології вирошування, строку сівби та ширини міжряддя. Наведено динаміку врожайності культури за останні три роки. Проаналізовано оптимальну площу живлення соняшнику в умовах достатнього зволоження. Наведено врожайність соняшнику за категоріями господарств.
\end{abstract}

Ключові слова: соняшник, строки сівби, способи сівби, гібриди урожайність, продуктивність.

Summary. The article has examined the results of the supply of special features, economic efficiency, development of the form for the sleep book, fall in technology elements, the line of width and width of the width. The dynamics of the culture of culture for the remaining three rocks have been brought. The optimal area is analyzed for the life of the sleepwort in the minds of well-willed. Induced the birthright of the sleepwalker for categories of state thanks.

Key words: sunflower, sowing time, sowing methods, hybrids yield, productivity.

$$
\text { DOI : 10.33783/1977-4167-2019-46-2-61-66 }
$$

Постановка проблеми. На сьогодні і у майбутнього важливою науковою проблемою є підвищення продуктивності рослин, якості насіння, економічної та енергетичної ефективності технологій вирощування соняшнику за рахунок підбору гібридного складу, оптимізації густоти стояння рослин та застосування науково обгрунтованої системи удобрення, зокрема шляхом застосування для позакореневого підживлення комплексних добрив з мікроелементами.

Погодні умови впродовж проведення досліджень характеризувалися значними коливаннями порівняно із середніми багаторічними показниками, що давало можливість установити реакцію гібридів соняшнику на агроекологічні чинники вирощування.

Результати розрахунку участі чинників у формуванні врожаю свідчать про те, що врожайність досліджуваних гібридів соняшнику найбільше визначається чинником «Ширина міжряддя» $31 \%$. Суттєвий вплив мали чинники «Погодні умови» - $24 \%$, взаємодія чинників «Гібрид» $21 \%$ та «Строки сівби» $-18 \%$.

Аналіз останніх досліджень і публікацій. Теоретичною та методологічною основою досліджень впливу строків сівби та ширини міжряддя на врожайність соняшнику є основні положення, ви- кладені у роботах вітчизняних та зарубіжних фахівців, зокрема: А. С. Бритвєнко, В. В. Нестерчук, С. В. Коковіхін, М. П. Ніценко.

Мета статті - визначити вплив строків сівби та ширину рядків на об’єми врожаю соняшнику.

Виклад основного матеріалу дослідження. Україна є найбільшим виробником та експортером насіння соняшнику та продуктів його перероблення на світовому ринку. Ця культура користується достатньо високим попитом на внутрішньому та зовнішньому ринках, а також характеризується високою ліквідністю. Соняшник залишається однією зі стратегічних культур та приносить значні прибутки аграрним підприємствам України.

Аналіз статистичних даних (табл. 1) свідчить, що урожай олійних в Україні у 2017 р. порівняно 32016 р. скоротився майже на $3 \%$. Разом 3 тим, скорочення валового збору насіння соняшнику передбачається в межах 8-12\%. Даний факт можна пояснити, здебільшого, складними погодними умовами сезону, а саме: значна посуха в період дозрівання та, як наслідок, скорочення врожайності культури на $10 \%$.

Рекордний за багато років урожай соняшнику було отримано у 2018 р. - майже 14,2 млн т. Це на 12 \% більше порівняно з показниками минулого року.

(с) А. А. Клименко, Х. Д. Гуренко, С. Ю. Качковський, 2019

Бібліографія ДСТУ 8302:2015:

Клименко А. А., Гуренко Х. Д. , Качковський С. Ю. Вплив строків сівби та ширини міжряддя на врожайність соняшнику. Вісник Бердянського університету менеджмменту і бізнесу. 2019. № 2 (46). С. 61-66.

References (APA):

Klymenko, A. A., Hurenko, Kh. D. , Kachkovskyi, S. Iu. (2019). Vplyv strokiv sivby ta shyryny mizhriaddia na vrozhainist soniashnyku [Influence of sowing time and row spacing on sunflower yield]. Visnyk Berdianskoho universytetu menedzhmentu $i$ biznesu, 2 (46), 61-66 (in Ukr.). 
Динаміка врожайності соняшнику в Україні 2016-2019 рр.

(складено за даними Державної служби статистики [1 с. 120, 2])

\begin{tabular}{|l|c|c|c|c|c|c|}
\hline \multirow{2}{*}{ Показник } & \multicolumn{3}{c|}{ Роки } & \multicolumn{3}{c|}{ Відхилення } \\
\cline { 2 - 8 } & 2016 & 2017 & 2018 & 2019 &,+- & $\%$ \\
\hline Урожайність 3 1 га зібраної площі & 22,4 & 20,2 & 23,0 & 23,9 & $+1,5$ & 1,07 \\
\hline Площа, з якої зібрано врожай, тис. га & 6086,7 & 6060,7 & 6166,5 & 5849,3 & $-239,4$ & 0,96 \\
\hline Валовий збір, т & 136269,0 & 122355,0 & 141652,0 & 121000,0 & $-15269,0$ & 0,89 \\
\hline Ціна за 1 ц, грн & 865,6 & 913,2 & 931,8 & 895,9 & $+30,3$ & 1,04 \\
\hline
\end{tabular}

Протягом 2019 р. лідерами за показниками врожайності соняшнику стали Полтавська $(2,59$ т/га) та Харківська (2,11 т/га) області. Водночас на території України (переважно південь країни) показник урожайності коливався в межах 1,42 т/га.

Необхідно зазначити таку тенденцію - зростання показників урожайності та продуктивності праці негативно впливає на рентабельність, яка має тенденцію до зменшення. Ця ситуація зумовлена, у першу чергу, низькими темпами зростання цін на соняшник, які майже не залежать від показників активності виробників сільськогосподарської продукції.

У разі зростання урожайності та продуктивності праці, відбувається постійне зниження рентабельності, зумовлене низькими темпами підвищення цін реалізації соняшнику, які майже не залежать від зусиль сільськогосподарських товаровиробників. У табл. 2 наведено дані врожайності соняшнику залежно від категорії господарств.

Урожайність соняшнику за категоріями господарств, центнерів 31 га зібраної площі

Таблиия 2 (складено за даними Державної служби статистики [3])

\begin{tabular}{|l|c|c|c|c|c|}
\hline \multirow{2}{*}{\multicolumn{1}{|c|}{ Категорії господарств }} & \multicolumn{3}{|c|}{ Роки } & \multicolumn{2}{c|}{ Відхилення 2018/2016 } \\
\cline { 2 - 6 } & 2016 & 2017 & 2018 &,+- & 1,03 \\
\hline Господарства всіх категорій & 22,4 & 20,2 & 23,0 & 0,6 & 1,03 \\
\hline Підприємства & 23,5 & 21,3 & 24,1 & 0,6 & 1,03 \\
\hline У т. ч. фермерські господарства & 21,2 & 18,9 & 21,9 & 0,7 & 0,05 \\
\hline Господарства населення & 17,2 & 15,2 & 18,0 & 0,8 & \\
\hline
\end{tabular}

Виходячи 3 наведених статистичних даних, можна зробити висновок, що показники врожайності у 2018 р. значно зросли порівняно з 2017, який характеризувався падінням темпів урожайності соняшнику. Найбільша частка соняшнику припадає на сільськогосподарські підприємства. У 2018 р. цей показник становить 24,1 ц/га, що на 13,1 \% або на 2,7 ц/га більше за аналогічний показник 2017 p.

Зростання попиту на жири рослинного походження протягом 90-х років минулого століття призвело до зміни у розподілі посівних площ аграрного сектору України. Значну частку в структурі посівних площ зайняли олійні культури, найпопулярнішою серед яких став соняшник. За останні 20 років площі під соняшником зросли з 1,6 млн га до 4,1-4,5 млн га. Розширюються посівні площі й інших олійних культур - таких як ріпак та соя. Так за аналогічний період посівні площі ріпаку збільшилися у 12 разів, а валовий збір - у 14,4 разу; сої - у 7 та 11 разів відповідно. Загалом, вітчизняна галузь виробництва олійних культур протягом 20 років демонструє зростання та розширення. Свідченням цього є збільшення посівних площ і валових зборів основних олійних культур України. Проте зростання це відбувало- ся екстенсивним шляхом, а рівень урожайності майже не змінився з 1990 р. Аграрний сектор економіки України потребує підвищення ефективності виробництва олійних культур, що можливо за умови удосконалення технологій, підвищення рівня матеріально-технічної бази, чіткого дотримання агротехнічних вимог. Це стосується і галузі виробництва олійних культур [4].

Питанням, які пов'язані 3 виробництвом олійних культур, приділяється значна увага у працях науковців. Так, О. С. Сало відмічає важливість моніторингу регіональних ринків олійних культур, під впливом яких формується вітчизняна олійна галузь. Автор загострює увагу на необхідності покращення технологічного забезпечення галузі (засоби захисту рослин, добрива, елітне насіння). Зменшення витрат на технологічне забезпечення, на його думку, призводить до зниження урожайності. Питаннями виробництва основних олійних культур займаються також Н. В. Потриваєва, І. В. Чехова, І. О. Кислицька, Т. 3. Таранюк, які в основу своїх досліджень покладають проблеми підвищення економічної ефективності виробництва основних олійних культур та визначення факторів розвитку олієжирового комплексу загалом [5]. 
Україна продовжує нарощувати посівні площі під соняшник. Якщо ще кілька років тому площі під культурою в 5 млн га вважалися максимально можливими, то вже сьогодні показник у 7 млн га і вище - цілком реальна перспектива на найближчі роки.

На сьогодні одним з основних заходів підвищення врожайності соняшнику є впровадження у виробництво нових високопродуктивних гібридів. Проте реалізація їх потенціалу потребує створення умов, які б відповідали біологічним особливостям даних гібридів. В умовах виробництва максимальний потенціал продуктивності рослин соняшнику може проявитися лише за дотримання усіх агротехнічних прийомів, які створюють оптимальні умови для їх росту і розвитку.

Аналіз літературних джерел свідчить, що сівба соняшнику в оптимальні строки сприяє отриманню своєчасних дружніх сходів, що визначає рівень урожайності загалом. Оптимальний строк сівби високоолійних гібридів і сортів настає в той час, коли середньодобова стійка температура грунту на глибині 10 см досягає $+10 \ldots+12{ }^{\circ} \mathrm{C}$. Такий строк сівби дозволяє знищити перед посівною культивацією основну масу сходів ранніх однорічних бур'янів, заробити насіння соняшника в добре прогрітий, чистий грунт і одержати дружні сильні сходи на 9-12-й день після сівби. Однак, виходячи з конкретних грунтово-кліматичних умов, строки сівби можна диференціювати. Результати досліджень різних науково-дослідних установ дозволяють допускати відстрочку сівби соняшнику на 10-15 днів, порівняно з оптимальними строками. За результатами досліджень [6], відстрочка з сівбою до першої декади травня дозволила одержати максимальну врожайність насіння. Проте в роки зі швидким настанням тепла навесні ранні строки сівби забезпечували не менший урожай, ніж середні. Сівба в пізні строки (за винятком окремих років) призводила до зниження врожайності.

Окремі науковці вважають, що соняшник $є$ культурою раннього строку сівби у зв'язку з його біологічними особливостями, з одного боку, і надзвичайною чутливістю, навіть до незначних осінніх приморозків у період дозрівання, з другого [7].

На підставі виявленої тісної зворотної залежності між масою сухої речовини ядра, олійністю та температурою в період сівби - сходи рекомендується в умовах Лісостепу сіяти соняшник в оптимально ранні строки за середньодобової температури повітря 7-9 ${ }^{\circ}$. Деякі вчені вказують, що сіяти його доцільно за температури грунту 8-10 ${ }^{\circ} \mathrm{C}$ - урожайність підвищується на 0,22-0,46 т/га, а збір олії - на 188-271 кг/га, одержана продукція при цьому не містить залишків пестицидів та інших шкідливих речовин [8].

Вибір оптимального строку сівби та густоти стояння рослин є передумовою ефективного ви- користання ресурсів середовища для формування високого врожаю посівами.

Проходження соняшником вегетації в оптимальні строки сприяє кращому використанню осінньо-зимово-ранньовесняних запасів грунтової вологи, знижує імовірність попадання фаз розвитку та дозрівання в несприятливі умови.

Окремі автори вважають, що соняшник $€$ культурою раннього строку сівби (температура грунту $4-6{ }^{\circ} \mathrm{C}$ ) через його біологічні особливості з одного боку і надзвичайну чутливість, навіть до незначних осінніх приморозків у період дозрівання, $з$ другого.

Інші пропонують проводити сівбу за прогрівання грунту до $8-10{ }^{\circ} \mathrm{C}$. Це забезпечує підвищення врожайності на 0,2-0,5 т/га. 3 позиції інших дослідників, оптимальний строк сівби настає за температури грунту $10-12{ }^{\circ} \mathrm{C}$ [9].

Варто врахувати, що зміна строків сівби зумовлює різні умови росту і розвитку як культури, так і бур'янів. Отже, потребує різного підходу до догляду за посівами.

Отже, нині відсутня стала наукова думка стосовно оптимальних строків сівби соняшнику. Це пов'язано з тим, що різні сорти та гібриди неоднаково реагують на оптимальні терміни сівби. Разом з тим, у виробництві великої кількості нових гібридів соняшнику, які відрізняються від вирощуваних раніше (скоростиглістю, морфобіологічними ознаками, підвищеною стійкістю проти затінення, хвороб, вилягання, вищою врожайністю та якістю продукції), актуальним і важливим для науки та виробництва залишається питання оптимальних строків сівби цієї культури в умовах Степу з метою поліпшення умов росту та розвитку рослин соняшнику та підвищення його продуктивності.

Необхідно розглянути вплив ширини міжряддя на формування продуктивності соняшнику.

Формування агрофітоценозу сільськогосподарської культури, включаючи соняшник, визначається впливом способів розміщення рослин на площі та густотою їх стояння. У зв’язку з цим, оптимізація розміщення рослин, як і загущення посівів, є надзвичайно актуальним питанням. Великої уваги потребують на сьогодні дослідження, спрямовані на вивчення особливостей розвитку та росту рослин нових гібридів соняшнику, поглинання ними ФАР, водоспоживання, формування продуктивності. 3 метою отримання високих урожаїв соняшнику слід створити певну морфологічну структуру агрофітоценозу, здатну найбільш ефективно використовувати фактори навколишнього середовища за рахунок оптимальної кількості рослин на одиниці площі для забезпечення максимального використання культурою сонячної радіації та родючості грунту з метою одержання господарсько-цінної продукції. 
Одержання високої врожайності з одиниці площі для сільськогосподарського виробника має більше значення, ніж реалізація потенційної врожайності кожної рослини.

Надмірне загущення посівів призводить до зменшення врожайності соняшнику у зв'язку з посиленням конкуренції між рослинами. За збільшення густоти рослин більша частина запасів вологи витрачається до настання в них генеративного періоду.

Як стверджують літературні джерела, рівномірне розміщення рослин на площі забезпечує настання їх взаємного пригнічення набагато пізніше. Варто зазначити, що за загущення посівів взаємне пригнічення рослин негативно впливає на формування вегетативної маси агроценозу починаючи з фази бутонізації.

Конкуренція та недорозвинення частини елементів структури врожаю має місце також у високопродуктивних посівах соняшнику.

Основним способом сівби соняшнику до сьогодні є пунктирний з шириною міжряддя 70 см. У 60-ті роки XX ст. таку ширину міжряддя встановили з метою проведення міжрядних обробітків для знищення бур'янів. Оскільки навіть за застосування гербіцидів, міжрядні обробітки є необхідним заходом для вирощування соняшнику.

Завдяки впровадженню у виробництво гібридів нового морфологічного типу та застосування міжряддя довширшки 45 см, оптимізуючи форму площі живлення, наближаючи її до квадрата, вдалося забезпечити підвищення врожайності. За густоти рослин 35-75 тис. на га і ширини міжряддя 70 см площа живлення має вигляд прямокутника. За збільшення густоти стояння відстань між рослинами в рядку зменшується. За таких умов розміщення на кожному погонному метрі рядка розмішується від 2,4 до 5,2 рослин. Проте варто врахувати, що за підвищення густоти рослин спостерігається посилення конкуренції між ними. А це призводить до зниження врожайності насіння.

Разом $з$ тим, за звуження міжряддя до $35 \mathrm{~cm}$ кількість рослин на 1 погонному метрі рядка зменшується удвічі. За таких умов рівномірність розміщення рослин на площі значно покращується порівняно з посівами з міжряддями 70 см. Варто зазначити, що за густоти 75 тис. рослин/га площа живлення наближається до квадрата (35 х 38 см). Збільшення густоти посіву з 35 до 75 тис. рослин/га приводить до рівномірного розміщення соняшнику на площі. Така закономірність прослідковується зокрема й у посівах з шириною міжряддя 70 см.

За сівби соняшнику з густотою 35 тис. рослин/га та шириною міжряддя 35 і 70 см відношення середньої відстані між рослинами в рядку до ширини міжряддя відповідає 2,34 та 1,17. Поряд 3 цим, загустоти 52 тис. рослин/га ці показники складають 1,6 та 0,5, тоді як за густоти 70 тис. рос- лин/га - 0,6 та 0,3. Варто зазначити, що відповідні показники 1,$17 ; 0,5 ; 0,3$ вказують на значне відхилення форми площі живлення від квадрата, що є наслідком підвищення конкуренції між рослинами за елементи живлення, світло та вологу.

3 метою зменшення випаровування води використовують раціональну схему сівби культур. Замість традиційної широкорядної (з міжряддям 70 см) сівби соняшнику сівбу проводять із вузькими (15-45 см) міжряддями - так звану «суцільну сівбу» [10].

Сівба низькорослих гібридів соняшнику в степовій зоні з міжряддями 30-45 см 3 підвищенням на 15-20 \% посівної норми підвищує врожайність. Дане явище забезпечується за рахунок рівномірного розміщення рослин на площі й скорочення втрат вологи. За широкорядного способу сівби середня площа живлення однієї рослини відповідає 28-70 см, то за вузькорядного - вона нагадує ромб зі сторонами 25-40 см. У вузькорядних посівах рослини замикають рядки на 10 днів раніше, ніж у звичайних з міжряддями 70 см, що забезпечує зменшення перегрівання грунту та суттєво знижує непродуктивне випаровування вологи.

В умовах Степу соняшник можна вирошувати з міжряддями 70 і 35 см. Аналіз літературних джерел засвідчує, що найвищу врожайність (3,55 т/га) було одержано в посівах 3 міжряддями 35 см за густоти рослин 75 тис. на га. Варто зазначити, що в посушливих умовах 2012 р. при загущенні посіву від 52 до 75 тис. рослин/га і звуженні міжряддя врожайність не підвищувалася у зв'язку з недостатньою кількістю вологи. За ширини міжряддя 70 см оптимальна густота має відповідати 52 тис. рослин/га. За умови іiі збільшення чи зменшення врожайність культури має знижуватися [11].

Оптимальною площею живлення соняшнику в умовах достатнього зволоження є 1800-2000 см² (55-50 тис. шт./га), у напівпосушливих умовах 2400-2800 см² (41-36 тис. шт./га) і в посушливих - 3200-4000 см² (32-25 тис. шт./га). За інтенсивного росту рослин основні запаси грунтової вологи витрачаються у першій половині вегетації, а в період формування й наливу насіння рослини часто страждають від нестачі вологи.

Соняшник формує однаковий урожай за різної ширини міжряддя: за умов недостатнього зволоження - 45-90 см, за достатнього - 45-70 см. Більше значення відіграє величина площі живлення, а не ії форма. Це можна пояснити пластичністю культури, зумовленою потужною кореневою системою, здатною за різного розташування рослин рівномірно використовувати поживні peчовини й вологу.

Аналіз продуктивності соняшнику при різних схемах посіву показав, що незалежно від густоти стояння рослин найвищий урожай забезпечив варіант $з$ параметрами міжряддя 45 см - 21,4 ц/га. 
Суцільно-рядковий посів з шириною міжряддя 15 см за рівнем урожайності практично не відрізнявся від контрольного варіанта з шириною міжряддя 70 см (19,3-19,6 ц/га). Доведено, що в умовах чорноземів південної степової зони України при вирощуванні сорту соняшнику Прометей доцільно застосовувати широкорядну пунктирну сівбу з міжряддями 45 см, і формувати передзбиральну густоту стояння рослин на рівні 50-55 тис га.

Варто зазначити, що одним із чинників, що визначають формування продуктивності посівів, є бур'яни. Попередні дослідження вказують на те, що за вирощування соняшнику без гербіцидів його посіви з міжряддями 35 см сформували вищу врожайність, ніж при 70 см, на 0,16-0,3 т/га, але вона була меншою на 0,73-0,81 т/га за проведення на широкорядному посіві двох міжрядних обробітків з обгортанням, при яких знищувалися і присипались, бур'яни. Рівномірне розміщення рослин на площі за сівби з міжряддями 35 см забезпечувало краще затінення грунту. У фазу цвітіння освітленість у посіві падала до 8-10\%, особливо в посівах 3 вищою густотою, і ріст бур'янів гальмувався сильніше, ніж у широкорядних посівах.

Результати дослідів вказують на важливу роль ширини міжряддя в біологічній можливості соняшнику пригнічувати розвиток бур'янів, що здатні суттєво знижувати врожайність насіння. Слід зазначити, що перехід на звужені міжряддя 15-35 см виключає міжрядні обробітки, за допомогою яких можна за необхідності суттєво знизити забур'яненість широкорядних посівів (45-70 см). Відсутність страхових гербіцидів на забур'янених, особливо багаторічними бур'янами, полях соняшник слід сіяти широкорядним способом із подальшим застосуванням міжрядних обробітків для знищення бур'янів. Позитивні результати можна досягти також завдяки допосівній обробці сходів бур'янів гербіцидом суцільної дії раундапом, що зменшить або зовсім виключить необхідність проведення механічних прийомів догляду за соняшником.

За сівби з міжряддями 15 та 35 см важливими і головними прийомами знищення бур'янів, без сумніву, є біологічні можливості культури, з подальшим застосуванням боронування і гербіцидів.

Висновки 3 проведеного дослідження. Проведені дослідження свідчать, що соняшник доцільно вирощувати не тільки 3 міжряддями 70 см, але й зі звуженими до 35 і навіть 15 см. У цьому випадку густоту стояння рослин порівняно з широкорядним способом сівби слід підвищувати до 80-90 тис./га, а догляд за посівами має включати боронування до і після сходження або використання гербіцидів.

\section{Література}

1. Рослинництво України за 2018 рік. Статистичний збірник / Державна служба статисти- ки України. URL : http://www.ukrstat.gov.ua/druk/ publicat/kat_u/2019/zb/04/zb_rosl_2018.pdf.

2. Обсяг виробництва, урожайність та зібрана площа сільськогосподарських культур за їх видами на 01 жовтня 2019 року. URL : http://www. ukrstat.gov.ua/operativ/operativ2019/sg/ovuzpsg/ Arh_ovuzpsg_2019_u.html.

3. Державна служба статистики України. URL : http://www.ukrstat.gov.ua.

4. FAO, 2013. FAO Statistical Yearbook - World Food and Agriculture. Rome : Food and Agriculture Organization of the United Nations. 289 p. ISBN 97892-5-107396-4.

5. Бритвєнко А. С. Напрями розвитку і підвищення економічної ефективності виробництва та переробки соняшнику в регіонах України. Вісник Бердянського університету менеджменту $і$ бізнесу. 2013. № 2. C. 110-113.

6. Нестерчук В. В. Напрями оптимізації елементів технології вирощування гібридів соняшнику в умовах півдня України. Зрошуване землеробство : міжвідомчий тематичний збірник наукових праць. 2015. Вип. 63. С. 84-86.

7. Горбатюк Е. М. Формування продуктивності соняшнику залежно від строків сівби та ширини міжряддя в умовах степу України. URL : http://nubip.edu.ua/sites/default/files/u145/dis_ gorbatyuk.pdf.

8. Еременко О. А. Продуктивність гібридів соняшнику (Helianthus annuus L.) в умовах південного Степу України. Збірник наукових праць Національного наукового центру "Інститут землеробства НААН». 2017. Вип. 1. С. 127-139.

9. Нестерчук В. В. Продуктивність гібридів соняшнику залежно від густоти стояння рослин та удобрення при вирощуванні в умовах півдня України. Зрошуване землеробство: Міжвідомчий тематичний збірник наукових праць. 2015. Вип. 64. C. $125-127$.

10. Коковіхін С. В., Нестерчук В. В., Носенко Ю. М. Продуктивність та якість насіння гібридів соняшнику залежно від густоти стояння рослин та удобрення. Таврійський науковий вісник. 2015. Вип. 94. С. 37-42.

11. Ніценко М. П. Особливості формування високопродуктивних посівів соняшнику при зміні ширини міжряддя і густоти стояння рослин. Бюлетень Інституту сільського господарства степової зони. 2014. № 6. С. 47-52.

\section{References}

1. State Statistics Service of Ukraine (2018). Roslynnytstvo Ukrainy za 2018 rik [Crop production of Ukraine in 2018]. Retrieved from http://www. ukrstat.gov.ua/druk/publicat/kat_u/2019/zb/04/zb_ rosl_2018.pdf.

2. State Statistics Service of Ukraine (2019). Obsiah vyrobnytstva, urozhainist ta zibrana ploshcha 
silskohospodarskykh kultur za yikh vydamy na 01 zhovtnia 2019 roku [The volume of production, yield and harvested area of crops by their types as of October 01, 2019]. Retrieved from http://www.ukrstat. gov.ua/operativ/operativ2019/sg/ovuzpsg/Arh_ ovuzpsg_2019_u.html.

3. Derzhavna sluzhba statystyky Ukrainy [State statistics service of Ukraine]. Retrieved from http:// www.ukrstat.gov.ua/.

4. FAO (2013). FAO Statistical Yearbook - World Food and Agriculture. Rome : Food and Agriculture Organization of the United Nations. 289 p.

5. Brytvienko, A. (2013). Napriamy rozvytku $i$ pidvyshchennia ekonomichnoi efektyvnosti vyrobnytstva ta pererobky soniashnyku $v$ rehionakh Ukrainy [Directions of development and increase of economic efficiency of production and processing of sunflower in the regions of Ukraine]. Visnyk Berdianskoho universytetu menedzhmentu i biznesu, 2, 110-113.

6. Nesterchuk, V. (2015). Napriamy optymizatsii elementiv tekhnolohii vyroshchuvannia hibrydiv soniashnyku v umovakh pivdnia Ukrainy [Directions of optimization of elements of technology of cultivation of sunflower hybrids in the conditions of the South of Ukraine]. Zroshuvane zemlerobstvo, 63, 84-86.

7. Horbatiuk, E. Formuvannia produktyvnosti soniashnyku zalezhno vid strokiv sivby ta shyryny mizhriaddia $v$ umovakh stepu Ukrainy [Formation of sunflower yield depending on sowing time and row spacing in the steppe of Ukraine]. Retrieved from http://nubip.edu.ua/sites/default/files/u145/dis gorbatyuk.pdf.

8. Yeremenko, O. Produktyvnist hibrydiv soniashnyku $v$ umovakh pivdennoho Stepu Ukrainy [Productivity of sunflower hybrids (Helianthus annuus L.) in the southern Steppe of Ukraine]. Zbirnyk naukovykh prats Natsionalnoho naukovoho tsentru «Instytut zemlerobstva NAAN», 1, 127-139.

9. Nesterchuk, V. Produktyvnist hibrydiv soniashnyku zalezhno vid hustoty stoiannia roslyn ta udobrennia pry vyroshchuvanni $v$ umovakh pivdnia Ukrainy [ Productivity of sunflower hybrids depending on the density of standing plants and fertilizers when grown in the South of Ukraine]. Zroshuvane zemlerobstvo, 64, 125-127.

10. Kokovikhin, S., Nesterchuk, V., Nosenko, Yu. Produktyvnist ta yakist nasinnia hibrydiv soniashnyku zalezhno vid hustoty stoiannia roslyn ta udobrennia [Productivity and quality of seeds of sunflower hybrids depending on the density of standing plants and fertilizers]. Tavriiskyi naukovyi visnyk, 94, 37-42.

11. Nitsenko, M. Osoblyvosti formuvannia vysokoproduktyvnykh posiviv soniashnyku pry zmini shyryny mizhriaddia i hustoty stoiannia roslyn [ Features of formation of highly productive crops of sunflower at change of width of aisles and density of standing of plants]. Biuleten Instytutu silskoho hospodarstva stepovoi zony, 6, 47-52. 


\title{
МОДЕЛЮВАННЯ ТРУДОВОГО ПОТЕНЦАЛУ АГРОПРОМИСЛОВИХ ПІДПРИЕМСТВ
}

\begin{abstract}
Анотащія. У статті розглянуті особливості змісту, структури, відтворення трудового потенціалу агропромислових підприємств та моделювання його розвитку. Виявлені основні складові та чинники використання трудових ресурсів, його ризики, проблеми й тенденції. Охарактеризовані етапи процесу моделювання трудового потенціалу підприємств на перспективу. Обгрунтовано важливість форм його використання. Визначено математичну модель відтворення трудового потенціалу як певну системну процедуру.

Ключові слова: агропромислові підприємства, трудовий потенціал, трудові ресурси, відтворення, моделювання, розвиток, управління.

Summary. In the article features of the content, structure, reproduction of labor potential of agroindustrial enterprises and modeling of its development are considered. The main components and factors of the use of labor resources, its risks, problems and tendencies are revealed. The stages of the process of modeling the labor potential of enterprises for the future are described. The importance of the forms of its use is substantiated. The mathematical model of reproduction of labor potential as a certain system procedure is determined.
\end{abstract}

Key words: agroindustrial enterprises, labor potential, labor resources, reproduction, modeling, development, management.

$$
\text { DOI : 10.33783/1977-4167-2019-46-2-67-70 }
$$

Постановка проблеми. Ефективність розвитку підприємств переробних галузей зумовлює своя система чинників. До основної групи чинників, які визначають ефективність, зокрема, м'ясопереробного виробництва, можна віднести технічні (стан машинного устаткування, технологіï); економічні (кон'юнктура ринку, цінова політика); соціальні (розвиток соціальної інфраструктури, організація праці та матеріальне стимулювання, трудові ресурси і їх кваліфікація). На сучасному етапі розвитку агропромислових підприємств саме такий соціальний чинник, як трудові ресурси набуває найбільшого значення в контексті ефективного функціонування підприємств галузі. Тому всебічна оцінка, діагностика й моделювання іх потенціалу є актуальним, має теоретичне й практичне значення.

Аналіз останніх досліджень і публікацій. Різні аспекти розвитку трудових ресурсів аграрних підприємств, їх потенціалу знайшли відображення у працях М. Ігнатенка, Ю. Гринчук, П. Макаренка, М. Маліка, Л. Мармуль, І. Романюк. У публікаціях вказаних авторів, інших науковців висвітлені проблеми відтворення трудоресурсного потенціалу аграрних та переробних підприємств, управління ним, мобільності кадрів, продуктивності праці, інституційного забезпечення. Проте пи- тання моделювання трудоресурсного потенціалу потребують поглиблених розробок.

Мета статті - виявити чинники розвитку трудового потенціалу агропромислових підприємств, встановити особливості його відтворення та обгрунтування змісту й етапів процесу моделювання.

Виклад основного матеріалу дослідження. Трудові ресурси традиційно розглядаються як соціально-економічна категорія, потенціал, що, 3 одного боку, відображає рівень розвитку продуктивних сил, а також їх кількісну, якісну характеристику і структуру, тобто розподіл на працездатне і непрацездатне населення. 3 другого боку, вони характеризуються складною системою взаємозв'язків, виробничими відносинами, тенденціями соціально-політичного розвитку, демографічними, національними традиціями, численними соціокультурними чинниками, і відтворюються разом з ними.

Те, що трудові ресурси є суб'єктами відносин, які складаються в процесі їх формування, розподілу, обміну і використовування, й одночасно $е$ суб'єктами управління, яке виражається, зокрема, в державному регулюванні розподілу і перерозподілу трудових ресурсів, підготовці кадрів, забезпеченні зайнятості й тому подібне, зумовлює необхідність розглядати їх і як важливий обліко-

(C) В. І. Пілявський, 2019

Бібліографія ДСТУ 8302:2015:

Пілявський В. І. Моделювання трудового потенціалу агропромислових підприємств. Вісник Бердянського університету менеджменту і бізнесу. 2019. № 2 (46). С. 67-70.

References (APA):

Piliavskyi, V. I. (2019). Modeliuvannia trudovoho potentsialu ahropromyslovykh pidpryiemstv [Modeling of labor potential of agro-industrial enterprises]. Visnyk Berdianskoho universytetu menedzhmentu i biznesu, 2 (46), 67-70 (in Ukr.). 
во-статистичний показник, і як соціально-економічну категорію одночасно [1, с. 278].

Необхідно зазначити, що формування трудових ресурсів і їх використання в різних галузях економіки мають свої особливості. У сільському господарстві з розвитком продуктивних сил, науково-технічного прогресу скорочується кількість працівників, зайнятих безпосередньо виробництвом продукції, збільшуються вимоги до рівня кваліфікації, з'являється необхідність регулярного навчання працівників. Специфічною рисою аграрного виробництва є також тісний зв'язок 3 природно-кліматичними умовами, біологічними особливостями і характеристиками основних засобів і ресурсів.

Завдання моделювання використовування трудових ресурсів полягає в тому, щоб створити збалансовану структуру управління, за допомогою якої кваліфікація кожного працівника відповідатиме вимогам і особливостям робочого місця, яке він займає [2, с. 176]. За такої відповідності можливо досягти максимального рівня продуктивності, тобто найефективнішого використовування трудового потенціалу працівників, зайнятих на підприємствах регіону. Управляти трудовим потенціалом означає забезпечити його розширене відтворення й приведення в рух у необхідному для суспільства напрямі всі джерела їх формування:

- молодь, що досягла працездатного віку, у тому числі що закінчила загальноосвітні школи, професійно-технічні училища, технікуми і ВН3;

- особи працездатного віку, які ведуть домашнє й особисте підсобне господарство;

- пенсіонери та інваліди, що зберегли працездатність;

- працівники, вивільнені з виробництва унаслідок різних причин;

- працездатне населення, що мігрує з села в місто;

- студенти ВН3, коледжів, що навчаються на денних відділеннях, і сумісники навчання у сфері виробництва і послуг;

- демобілізовані з лав збройних сил.

У зв'язку з вищевикладеним, аналіз і моделювання використовування трудових ресурсів необхідно виконувати з урахуванням таких характерних особливостей:

- трудові ресурси розглядаються як складна слабоструктурована система, що характеризуються великою кількістю складних взаємозв'язаних причинно-наслідкових зв'язків між чинниками, результат дії яких не завжди очевидний при ухваленні рішень, а також необхідністю дослідження стохастичних систем в умовах невизначеності, неоднозначності;

- трудові ресурси - соціальна система, тому в ній домінують і враховуються психологічні та психофізіологічні чинники. Під час ухвалення рішень необхідно враховувати довгострокові інтереси суспільства і повинен забезпечуватися розвиток і відтворювання людського потенціалу. Непродумані соціальні програми можуть призвести до зсувів, порушень балансу. Умовою нормального розвитку в системі є підтримка економічної рівноваги, балансу ресурсів у системі;

- трудовий потенціал - динамічна система; необхідно вивчати динаміку розвитку системи, проводити аналіз зміни показників використовування і процесів відтворення ресурсу з урахуванням загального життєвого циклу економічної системи;

- при управлінні трудового потенціалу часто виникає конфлікт між цілями довгострокового планування і короткостроковими рішеннями. Наприклад, збільшення кількості випускників може в майбутньому викликати зростання безробіття в деякій галузі в довгостроковій перспективі. Тому найбажанішим є таке рішення, яке сприяє стійкому розвитку в короткостроковій і довгостроковій перспективі.

Трудовий потенціал є цілеспрямованою і багатоцільовою системою, що має неоднорідні внутрішні та зовнішні цілі, самостійні підцілі окремих підсистем, систему показників вимірювання цілей, багатоманітні стратегії їх досягнення тощо. При виборі того або іншого варіанта використовування ресурсів необхідно формувати злагоджене рішення, що дозволяє знаходити компроміс між регіональними і загальнодержавними цілями, цілями окремих підприємств і господарських суб'єктів та окремих працівників [3, с. 14].

Виявлено, що складна система трудових ресурсів нелінійна. Сучасна математика має справу переважно з лінійними процесами. Але суспільство майже цілком характеризується нелінійними процесами. Поняттям нелінійності легко оперувати, якщо відмовитися від вимоги аналітичного рішення системи рівнянь і використовувати менш елегантний і більш емпіричний підхід до імітації системи. Ухвалення нелінійної природи систем концентрує нашу увагу на найважливішому питанні про структуру системи.

Моделювання використовування трудового потенціалу слід розглядати як чотирифазний процес.

Перша фаза - формування трудового потенціалу в певному кількісному і якісному вираженні. Це початковий етап відтворювального процесу і відіграє в ньому вирішальну роль, оскільки саме ця фаза визначає розвиток усіх наступних [4, c. 18]. Розширення ринкових відносин вносить нові акценти в процес формування трудових ресурсів, зміщуючи фокус уваги на якісне його вдосконалення, підвищення рівня загальної і професійної підготовки кадрів, на зростання соціальної і трудової активності. 
Розподіл по основних сферах і галузях суспільного виробництва - друга фаза відтворення, у якій відбувається адаптація трудових ресурсів. На цій стадії розв'язуються такі завдання: соціально-демографічний і професійно-кваліфікаційний розподіл; розподіли трудових ресурсів по сферах матеріального і нематеріального виробництва, а також по підприємствах різних форм власності; розподіл по робочих місцях на підприємствах, в організаціях тощо [5, с. 176]. Зміни в структурній перебудові економіки стали причиною значного перерозподілу трудових ресурсів між виробничою і невиробничою сферами. Цю тенденцію зумовили негативні процеси: спад виробництва в багатьох галузях, значні галузеві розбіжності в рівнях оплати праці, хронічна заборгованість з її виплатою і т. п.

Наступний етап у відтворенні трудового потенціалу - обмін. 3 переходом до ринкових відносин виникла необхідність у поглибленому аналізі стадії обміну, оскільки його значення у відтворювальному процесі істотно виросло. Це пов'язано з підвищенням ролі ринку праці у використовуванні трудових ресурсів. Ринок праці розглядається нами як складна система відносин щодо обміну індивідуальних здібностей до праці на фундацію життєвих засобів, необхідних для відтворення робочої сили, і розміщення працівників, у системі суспільного розподілу праці за законами товарного виробництва і обігу, забезпечуючи нормальний процес відтворення і використовування праці [6, с. 45].

Використовування (реалізація) трудового потенціалу відповідно до потреб виробництва є заключною фазою в процесі відтворення. Використовування трудового потенціалу тісно пов'язано з його формуванням і розподілом. Що більш раціонально розподілено трудовий потенціал у розрізі окремих територій і галузей, то більше значним може бути результат, досягнутий від використовування однієї і тієї самої величини сформованих трудових ресурсів.

Тому етап використовування трудових ресурсів є показником ефективності фаз його формування, розподілу та обміну [7, с. 68]. Одночасно використовування трудового потенціалу здійснює достатньо активний зворотний вПлив на процеси формування, розподілу й обміну, диктує їм свої вимоги, створює нові стимули для їх удосконалення.

Висновки. Для підвищення ефективності реалізації потенціалу трудових ресурсів ключова роль відводиться формам їх використовування - екстенсивній і інтенсивній. Екстенсивна форма передбачає залучення до господарського обігу його кількісної складової, а інтенсивна - характеризується введенням якісної складової трудових ресурсів. Для моделювання процесу відтворення трудового потенціалу агропромислового виробництва загалом, а також оцінки й аналізу ефективності різних програм, заходів управління нами запропоновано математичну модель, яку можна описати у вигляді системної процедури визначення чітких кількісних залежностей.

\section{Література}

1. Ігнатенко М. М. Стратегії та механізми управління розвитком соціальної відповідальності суб’єктів господарювання аграрної сфери економіки : монографія. Херсон : Айлант, 2015. 470 с.

2. Шимановська-Діанич Л. М. Управління розвитком персоналу організації: теорія і практика. Теоретичні підходи до аналізу форм активізації трудового потенціалу : монографія. Полтава : ПУЕТ, 2012. 462 c.

3. Романюк I. А. Особливості відтворювального процесу в аграрному секторі. Агросвіт. № 11. 2016. C. 12-15.

4. Гаращук О. В., Куценко В. І. Соціальна сфера - важливий чинник відродження сільських територій: стан, проблеми, шляхи їх розв'язання. Економіка розвитку. 2015. № 1 (73). С. 14-20.

5. Гриньова В. М., Писаревська Г. І. Управління кадровим потенціалом підприємства : монографія. Харків : Вид. ХНЕУ, 2012. 228 с.

6. Мармуль Л. О., Петренко В. С. Стратегічне позиціонування підприємств 3 іноземними інвестиціями в аграрній сфері економіки. Вісник Бердянського університету менеджменту $і$ бізнесу. 2017. № 4 (40). С. 43-48.

7. Мельник О. В. Виробничі ресурси аграрного спрямування: порівняльна характеристика дієвості на мікро- та макрорівнях на основі складових результативності. Економіка. Фінанси. Менеджмент: актуальні питання науки і практики. 2017. № 7. С. 65-71.

8. Бурєннікова Н. В., Ярмоленко В. О., Мельник О. В. Виробничі ресурси видів економічної діяльності України: порівняльна характеристика дієвості на базі складових результативності. Научный взгляд в будущее. 2017. Вып. 6. Т. 4. C. 4-13.

9. Мельник О. В. Сучасні аспекти стратегічного управління в аграрному секторі економіки України. Бізнес Інформ. 2017. № 6. С. 111-116.

\section{References}

1. Ihnatenko, M. M. (2015). Stratehiyi ta mekhanizmy upravlinnya rozvytkom sotsial'noyi vidpovidal'nosti sub'yektiv hospodaryuvannya ahrarnoyi sfery ekonomiky [Strategies and mechanisms for managing the development of social responsibility of economic entities of the agrarian sector of the economy]. Kherson, Aylant (in Ukr.).

2. Shymanovska-Dianych, L. M. (2012). Upravlinnya rozvytkom personalu orhanizatsiyi: teoriya $i$ 
praktyka [Organization development of personnel of the organization: theory and practice]. In Theoretical approaches to the analysis of forms of activation of labor potential. Poltava, PUET (in Ukr.).

3. Romaniuk, I. A. (2016). Osoblyvosti vidtvoryuval'noho protsesu $v$ ahrarnomu sector [Features of the reproduction process in the agrarian sector]. Ahrosvit, 11, 12-15 (in Ukr.).

4. Harashchuk, O. V. \& Kutsenko, V. I. (2015). Sotsialna sfera - vazhlyvyy chynnyk vidrodzhennya silskykh terytoriy: stan, problemy, shlyakhy yikh rozv'yazannya [The social sphere is an important factor in the revival of rural areas: the state, problems, ways of solving them]. Ekonomika rozvytku, 1 (73), 14-20 (in Ukr.).

5. Hrynova, V. M. \& Pysarevska, H. I. (2012). Upravlinnya kadrovym potentsialom pidpryyemstva [Management of personnel potential of the enterprise]. Kharkiv, KHNEU (in Ukr.).

6. Marmul', L. O. \& Petrenko, V. S. (2017). Stratehichne pozytsionuvannya pidpryyemstv $z$ inozemnymy investytsiyamy $v$ ahrarniy sferi ekonomiky [Strategic positioning of enterprises with foreign investments in the agrarian sector of the economy]. Visnyk
Berdyans'koho universytetu menedzhmentu $i$ biznesu, 4 40), 43-48 (in Ukr.).

7. Melnyk, O. V. (2017). Vyrobnychi resursy ahrarnoho spryamuvannya: porivnyalna kharakterystyka diyevosti na mikro- ta makrorivnyakh na osnovi skladovykh rezultatyvnosti [Agrarian production resources: comparative performance at micro- and macro-levels based on performance components]. Ekonomika. Finansy. Menedzhment: aktualni pytannya nauky i praktyky, 7, 65-71 (in Ukr.).

8. Buryennikova, N. V., Yarmolenko, V. O. \& Melnyk, O. V. (2017). Vyrobnychi resursy vydiv ekonomichnoyi diyalnosti Ukrayiny: porivnyalna kharakterystyka diyevosti na bazi skladovykh rezultatyvnosti [Production resources of types of economic activity of Ukraine: comparative characterization of efficiency on the basis of components of efficiency]. Nauchnyy vzhlyad $v$ budushchee, 6 (4), 4-13 (in Ukr.).

9. Melnyk, O. V. (2017). Suchasni aspekty stratehichnoho upravlinnya $v$ ahrarnomu sektori ekonomiky Ukrayiny [Current aspects of strategic management in the agrarian sector of the Ukrainian economy]. Biznes Inform, 6, 111-116 (in Ukr.). 


\title{
ФОРМУВАННЯ СОЦІАЛЬНОЇ СПРЯМОВАНОСТІ ПІДПРИЕМСТВ СІЛЬСЬКОГО ЗЕЛЕНОГО ТУРИЗМУ ТА СТРАТЕГІЇ ІІЇ РЕАЛІЗАЦІЇ
}

\begin{abstract}
Анотація. У статті розглянуто проблеми посилення соціальної спрямованості діяльності туристичних підприємств і підприємств сільського зеленого туризму зокрема. Обгрунтовано важливість иього процесу та вказані його позитивні наслідки. Виявлені негативні чинники, які перешкоджають соціологізації, серед яких недостатня мотивація, фінансові проблеми, слабка державна підтримка та ін. Проаналізовано зарубіжкний досвід, насамперед, європейський, соціологізації підприємств галузі. Здійснено оцінювання ефективності діяльності соціальних туристичних підприємств в Україні та пояснено тенденції ї зменшення. Виявлено резерви та запропоновано механізми й інструменти посилення соціальної спрямованості підприємств сільського зеленого туризму.
\end{abstract}

Ключові слова: туристичні підприємства, сільський зелений туризм, соціальна спрямованість, соціальний менеджмент, маркетинг, стратегії, реалізація, управління.

Summary. The article deals with the problems of strengthening the social orientation of tourism enterprises and rural green tourism enterprises in particular. The importance of this process is substantiated and its positive consequences are indicated. Negative factors that hinder sociologization are revealed. Among them, insufficient motivation, financial problems, weak state support, etc. Analyzed foreign experience, especially European, sociologization of enterprises in the industry. The evaluation of the effectiveness of social tourism enterprises in Ukraine and explained the trends of its decline. Identified reserves and proposed mechanisms and tools to strengthen the social orientation of rural green tourism enterprises.

Key words: tourism enterprises, rural green tourism, social orientation, social management, marketing, strategies, implementation, management.

DOI : $10.33783 / 1977-4167-2019-46-2-71-75$

Постановка проблеми. У сучасних умовах суспільної життєдіяльності та ії розвитку значущість функціонування туристичних підприємств, у т. ч. на рівні сільського зеленого туризму полягає в тому, що вони відіграють вагому соціально-економічну роль у житті суспільства, забезпечуючи відпочинок, особистісне зростання, культурний обмін і значну зайнятість населення та піднесення супутніх видів діяльності. Підприємства сільського зеленого туризму сприяють більш інтенсивному використанню вільних трудових ресурсів на селі; раціональному природокористуванню та м'якому впливу на довкілля; підвищенню рівня соціальноекономічного розвитку сільських територій, сільських громад, добробуту сільських жителів. Отже, можна стверджувати про зростання соціологізації або соціального спрямування діяльності підприємств сільського зеленого туризму.

Аналіз останніх досліджень і публікацій. Теоретико-методичні аспекти соціальної спрямованості розвитку й діяльності соціально-орієнтованих підприємств, зокрема туристичних, висвітлено у працях таких зарубіжних та вітчизняних науковців, як: Х. Адлер, Ф. Котлер, Д. Акимов, Л. Гопкало, К. Задорожна, М. Ігнатенко, Л. Мармуль, С. Мельниченко, О. Тищенко, І. Романюк, О. Сарапіна, I. Скриль та ін. Проте соціальні аспекти функціонування підприємств сільського зеленого туризму потребують подальших розробок. Незважаючи на досить помітну кількість праць, на сьогодні недостатньо дослідженими залишаються питання соціальної спрямованості й впровадження соціальних стратегій у діяльність підприємств сільського зеленого туризму та ринку туристичних послуг на селі.

Мета статті - розробити теоретичні та практичні рекомендації щодо формування і реалізації соціальної спрямованості й соціальних маркетингових стратегій функціонування підприємств сільського зеленого туризму.

Виклад основного матеріалу дослідження. Сучасна економічна теорія передбачає трактування закономірностей ринкового господарства, аналіз попиту і пропозиції як факторів, що забезпечують

(C) I. А. Романюк, 2019

Бібліографія ДСТУ 8302:2015:

Романюк I. А. Формування соціальної спрямованості підприємств сільського зеленого туризму та стратегії їі реалізації. Вісник Бердянського університету менеджменту і бізнесу. 2019. № 2 (46). С. 71-75.

References (APA):

Romaniuk, I. A. (2019). Formuvannia sotsialnoi spriamovanosti pidpryiemstv silskoho zelenoho turyzmu ta stratehii yii realizatsii [Formation of social orientation of the enterprises of rural green tourism and strategy of its realization]. Visnyk Berdianskoho universytetu menedzhmentu i biznesu, 2 (46), 71-75 (in Ukr.). 
ринкову рівновагу. Вона має також включати, як вважає Д. Акимов, дослідження позаринкових соціальних відносин між соціальними структурами та споживачами, які своєю поведінкою формують соціально-економічний простір та впливають на національну і світову економіку загалом [1, с. 49]. Тому соціальні аспекти діяльності підприємств сільського зеленого туризму не можуть мати другорядне значення перед економічними.

Історично склалося, що соціальна спрямованість розглядається як досить складний і суперечливий сегмент туристичної сфери. Її доцільно розглядати в контексті завдань та цілей соціальної політики, яка не грунтується на благодійності, але пропагує покращення умов життя і сприяння розвитку підприємництва, соціальній відповідальності, соціальному менеджменту.

На нашу думку, соціально орієнтованою є така туристична діяльність, яка передбачає забезпечення доступності послуг для широких верств населення; сприяння відпочинку малозабезпечених споживачів; розвиток самоосвіти й культури туристів; співпрацю з вітчизняними партнерами порівняно з іноземними за наявності інших рівних умов для підтримки вітчизняного бізнесу та підприємництва; благодійність.

3 іншого боку, соціальну спрямованість мають підтримувати й відповідні інститути організації та регулювання діяльності підприємств сільського зеленого туризму, - оподаткування, державно-приватне партнерство, підтримка сільських громад та неурядових установ. У цих умовах соціальні стратегії маркетингу відіграють важливу роль як системний інструмент соціальної орієнтації сучасних туристичних підприємств та ринкової економіки загалом. Від його розвитку значною мірою залежить і соціальна значущість підприємств сільського зеленого туризму.

Науковці, зокрема, Ф. Котлер, зазначають, що «соціальна концепція маркетингу - новітнє досягнення філософії бізнесу. Вона стверджує, що підприємство повинно визначати потреби, бажання й інтереси свого цільового ринку та задовольняти їх більш ефективно, ніж конкуренти, причому так, щоб підтримувати або підвищувати рівень добробуту споживача й суспільства у цілому» [2, с. 176].

Доволі поширеним є підхід, у межах якого соціальний маркетинг інтерпретується як реалізація маркетингової парадигми в соціальній сфері. Як вважає Л. Гопкало, соціальний маркетинг - це маркетинг спрямованих на поліпшення життя соціальних змін у способі життя, ідеалах, цінностях, нормах. Тому соціальний маркетинг стосується таких сфер, як туризм, культура, мистецтво, освіта, охорона здоров'я, релігія, політика тощо. Соціальний маркетинг - це маркетинг ідей, про- грам, особистостей, соціально значущих об'єктів, місць, соціальних інститутів [3, с. 35].

На думку С. В. Мельниченко «...соціальний маркетинг - це система поглядів на управління, яка завжди ставить потреби людей на перше місце порівняно з потребами виробництва, поряд з економічною соціологією вивчає вплив економічних факторів на різні форми соціальної поведінки людей, малих і великих соціальних груп» [4, с. 241].

У межах іншого підходу обгрунтовується розуміння соціального маркетингу як випадку маркетингу, що стосується соціально-етичних відносин. О. Тищенко підкреслює, що «...соціально-етичний маркетинг - це система вдосконалення наявних форм та методів розробки, виробництва та просування продукту з урахуванням впливу соціальних норм, етичних обмежень та ролі інтересів споживачів, виробників та суспільства на основі маркетингового підходу до процесів адаптивного розвитку підприємства» [5, с. 206].

Разом з тим, на думку М. Ігнатенка, у своїй соціально-економічній діяльності сільське туристичне підприємство має бути відповідальним перед своїми споживачами [6, с. 174]. Соціальна відповідальність маркетингової діяльності в таких умовах проявляється в роз'яснювальній роботі, наданні достовірної, прозорої та корисної інформації про продукти і послуги; сприянні стійкому споживанню; розробленні, виробництві і розповсюдженні товарів і послуг, доступних для всіх категорій клієнтів; збереженні довкілля; безпеці туристів; протидії корупції та бюрократії.

Загалом, під час визначення соціального маркетингу можна виділити чотири ознаки, якими він характеризується: розглядається як процес планування та прийняття управлінських рішень, на основі аналізу ситуацій і формулювання цілей; спрямований на вирішення соціальних завдань; належить до різних форм прояву некомерційних організацій із політичного, релігійного та культурного середовища; передбачає системний розвиток маркетингової концепції, яка спрямована на використання різних маркетингових інструментів.

Л. Мармуль, І. Романюк, І. Скриль вважають, що соціальний туризм доцільно розглядати в контексті завдань та цілей соціальної політики як діяльності підприємств, держави і суспільства загалом, що переслідує формування здорового способу життя людини в усіх його вимірах [7, с. $35 ; 8$, c. $25 ; 9$, с. 196]. К. Задорожна розглядає соціальний туризм з різних точок зору [10, с. 21]:

- по-перше, цей вид туризму тяжіє до туристичної бази, з наданням специфічних послуг і заохоченням до активної діяльності незалежно від ї форми власності;

- по-друге, соціальний туризм можна розглядати як сферу задоволення потреб вразливих верств населення, у якій кошти цілком або част- 
ково сплачуються не туристом, а організаціями або установами (соціального страхування, відомчими, громадськими організаціями;

- по-третє, соціальний туризм вимагає створення певних громадських об'єднань.

Як вказують М. Ігнатенко, О. Сарапіна та співавтори, у країнах Європейського Союзу соціальному туризму приділяється багато уваги. Так, наприклад, у Німеччині, Австрії, Бельгії, Польщі соціально-орієнтовані послуги сфери туризму фінансуються $з$ джерел місцевих бюджетів та різних фондів, які займаються організацією оздоровлення і відпочинку соціальних туристів, незважаючи на те, що в цих країнах система підтримки соціального туризму функціонує близько 70 років
[11, с. 338]. Попри це, постійно з'являються нові фонди, організації і туристичні підприємства, які займаються вирішенням питань фінансування оздоровлення та відпочинку соціальних туристів.

Однак у таких країнах, як Азербайджан, Казахстан, Киргизстан, Молдова соціальний туризм як окремий вид туристичної діяльності не розглядається взагалі. Відсутня нормативно-правова база, що визначала б соціальний туризм як один 3 видів туристичної діяльності. Аналіз статистичних даних суб'єктів підприємницької діяльності, що мають ресурсний потенціал та можливості для обслуговування соціальних туристів, свідчать про стійку тенденцію до зменшення пропозиції туристичних послуг для них і в нашій країні (табл. 1).

Таблиия 1

Динаміка кількості туристичних підприємств соціальної спрямованості в Україні у 2015-2017 рр., од. (складено автором за даними Державної служби статистики України)

\begin{tabular}{|l|c|c|c|c|}
\hline \multicolumn{1}{|c|}{ Показники } & & & Відхилення \\
& 2015 & 2016 & 2017 & +2015 \\
\cline { 2 - 5 } & & & & -4534 \\
\hline Кількість підприємств, од. & 15925 & 11606 & 11391 & -29 \\
\hline санаторії та пансіонати з лікуванням & 320 & 309 & 291 & -55 \\
\hline санаторії-профілакторії & 118 & 79 & 63 & -17 \\
\hline будинки і пансіонати відпочинку & 90 & 76 & 73 & -105 \\
\hline бази та інші заклади відпочинку & 1400 & 1399 & 1295 & -4328 \\
\hline дитячі заклади оздоровлення та відпочинку & 13997 & 9743 & 9669 & 2 \\
\hline
\end{tabular}

За період 2015-2017 рр. кількість туристичних підприємств суттєво зменшилась (табл. 2) на 4534 (скорочення - 39,0 \%). Що стосується даної статистики за основними типами підприємств, установлено, що у 2015 р. налічувалось 320 санаторіїв та пансіонатів з лікуванням, у 2017 р. - 291 (скорочення - 9,0 \%). Катастрофічного скорочення зазнали санаторії-профілакторії. Якщо у 2015 р. їх було 118, то у 2017 р. припинили роботу 55 закладів (скорочення - 87,0 \%). Дещо меншого скорочення зазнали будинки й пансіонати відпочинку: 73 заклади у 2017 р. проти 90 у 2015 р. (скорочення - 23,0 \%). Якщо у 2015 р. функціонувало 13997 дитячих закладів оздоровлення та відпочинку, то у 2017 р. припинили діяльність 4328 підприємств (скорочення - 44,0%).
Потрібно зазначити, що дана тенденція зменшення пропозиції виникає з причини перебування підприємств на капітальному ремонті, збільшення кількості непридатних до експлуатації з причини аварійності матеріально-технічної бази, відсутністю коштів для експлуатації закладів. У 2017 р. налічувалось 305 таких об’єктів, у т. ч. 35 літніх таборів та інших тимчасових засобів розміщення.

Кількість осіб, які скористались послугами соціально-орієнтованих підприємств сфери туризму, зменшилась у 2015-2017 рр. з 2982 тис. осіб до 2360 тис. осіб (на 26,0 \%). При цьому середня тривалість перебування відпочивальників у 2015 р. становила 13,5 днів, а у 2017 р. збільшилась до 15 днів, що є позитивною тенденцією. Фактич-

Таблиия 2

Динаміка кількості обслуговуваних осіб в соціально орієнтованих туристичних підприємствах України у 20152017 рр., тис. осіб (складено автором за даними Державної служби статистики України)

\begin{tabular}{|c|c|c|c|c|}
\hline \multirow[t]{2}{*}{ Показники } & \multirow[t]{2}{*}{2015} & \multirow[t]{2}{*}{2016} & \multirow[t]{2}{*}{2017} & $\begin{array}{c}\text { Відхилення } \\
2017-2015 \\
\end{array}$ \\
\hline & & & & $+/-$ \\
\hline Кількість оздоровлених, тис. осіб & 2982 & 2250 & 2360 & -622 \\
\hline у санаторіях та пансіонатах з лікуванням & 687 & 446 & 528 & -159 \\
\hline у санаторіях-профілакторіях & 130 & 61 & 63 & -67 \\
\hline у будинках і пансіонатах відпочинку & 81 & 76 & 71 & -10 \\
\hline у базах та інші закладах відпочинку & 738 & 750 & 762 & +24 \\
\hline у дитячих закладах оздоровлення та відпочинку & 1346 & 917 & 936 & -410 \\
\hline
\end{tabular}


ні витрати на один ліжко-день перебування у спеціалізованих закладах розміщення за досліджуваний період значно зросли, - з 278,0 грн на один ліжко-день у середньому за 12 місяців у 2015 р. до 423,0 грн у 2017 р. відповідно.

Що стосується підприємств сільського зеленого туризму, то важко оцінити їх соціальну спрямованість кількісно, оскільки спеціальна статистика цього напряму не ведеться. Загалом, дослідження особливостей функціонування соціальних туристичних підприємств дало змогу дозволило встановити, що основними проблемами, які стримують їх розвиток, є: складні суспільно-економічні умови; недостатня державна підтримка підприємств; слабка інформованість ринку; застаріла інфраструктура; низька якість послуг; незначний обсяг обслуговування.

Висновки. Ураховуючи високу соціальну значущість туризму для соціально вразливих верств населення, туристичні підприємства, у т. ч. сільського зеленого, повинні вирішувати ці питання першочергово у тісній взаємодії з органами влади та сільськими громадами. Лише створена система та мережа закладів соціального туризму на сучасному етапі здатна дати повноцінний туристичний продукт, який би задовольняв потреби всіх верств населення.

Соціальна спрямованість функціонування туристичних підприємств та підприємств сільського зеленого туризму зокрема є важливим чинником економічного, соціального, культурно-духовного, екологічного розвитку країни, регіонів, сільських територій. Саме соціальний туризм може стати визначальним чинником щодо ефективної реалізації концепції сталого розвитку, яка спрямована не тільки на економічне зростання, а й соціальний прогрес, охорону навколишнього природного середовища, гуманістичний, етичний і культурний розвиток загалом.

\section{Література}

1. Акимов Д. И. Социальный маркетинг : монография. К. : Наукова думка, 2008. 144 с.

2. Котлер Ф., Лі Н. Корпоративна соціальна відповідальність. Як зробити якомога більше добра для вашої компанії та суспільства. Житомир : Изд-во А. Капусты. 2005. 302 с.

3. Гопкало Л. М. Принципи оцінки і планування діяльності соціально-орієнтованого готельного підприємства. Вісник Національного університету водного господарства та природокористування. Економічні науки. 2015. №12. С. 34-42.

4. Мельниченко С. В., Магалецький А. В. Маркетингова політика в готельному бізнесі : монографія. К. : Київ. нац. торг.-екон. ун-т, 2011. 344 с.

5. Тищенко О. О. Соціально-етичний маркетинг: сутність, елементи, чинники розвитку. Держава та регіони. 2011. № 6. С. 204-208.
6. Ігнатенко М. М. Стратегії та механізми управління розвитком соціальної відповідальності суб’єктів господарювання аграрної сфери економіки : монографія. Херсон : Айлант, 2015. 470 с.

7. Мармуль Л. О., Ігнатенко М. М., Сарапіна О. А. Соціально-економічний потенціал сільських територій як основа розвитку підприємств сільського зеленого туризму на засадах інноваційності. Економіка і менеджмент культури. № 2. 2016. С. 32-38.

8. Романюк I. А. Стратегічне управління розвитком галузі туризму на засадах формування корпоративної культури туристичних підприємств. Вісник Бердянського університету менеджменту і бізнесу. 2016. № 2 (34). С. 24-27.

9. Скриль I. А. Соціальний туризм: сутність, переваги та перспективи розвитку. Вісник Харківського національного університету. 2014. № 824. С. 194-197.

10. Задорожна К. І. Соціальний туризм у системі туристичної галузі: концептуалізація та інтеграція. Вісник Чернівецького торговельно-економічного інституту. Економічні науки. 2016. Вип. 2. C. 17-27.

11. Ihnatenko M. M., Sarapina O. A., Sakun A. ZH., Marmul L. O., Pylypenko K. A. Models of implementation of enterprises in agricultural green tourism in European countries and assessment of their efficiency. International Journal of Innovative Technology and Exploring Engineering. Vol. 8. Iss. 12, October 2019. C. 337-340.

\section{References}

1. Akymov, D. Y. (2008). Sotsyalnyy marketynh [Social marketing]. Kyiv, Naukova dumka (in Ukr.).

2. Kotler, F. \& Li, N. (2005). Korporatyvna sotsialna vidpovidalnist. Yak zrobyty yakomoha bilshe dobra dlya vashoyi kompaniyi ta suspilstva [Corporate Social Responsibility. How to do the best possible for your company and society]. Zhytomyr, A. Kapusta Publ. (in Ukr.).

3. Hopkalo, L. M. (2015). Pryntsypy otsinky $i$ planuvannya diyalnosti sotsialno-oriyentovanoho hotelnoho pidpryyemstva [Principles of assessment and planning of socially-oriented hotel enterprise]. Visnyk Natsionalnoho universytetu vodnoho hospodarstva ta pryrodokorystuvannya. Ekon. nauky, 12, 34-42 (in Ukr.).

4. Melnychenko, C. B. \& Mahaletskyy, A. B. (2011). Marketynhova polityka $v$ hotelnomu biznesi [Marketing policy in the hotel business]. Kyiv, Kyiv. nats. torh.-ekon. un-t (in Ukr.).

5. Tyshchenko, O. O. (2011). Sotsialno-etychnyy marketynh: sutnist, elementy, chynnyky rozvytku [Socioethical marketing: essence, elements, factors of development]. Derzhava ta rehiony, 6, 204-208 (in Ukr.).

6. Ihnatenko, M. M. (2015). Stratehiyi ta mekhanizmy upravlinnya rozvytkom sotsialnoyi vidpovidalnosti subyektiv hospodaryuvannya ahrarnoyi sfery ekonomiky [Strategies and mechanisms for man- 
aging the development of social responsibility of economic entities in the agricultural sector]. Kherson, Aylant (in Ukr.).

7. Marmul, L. O., Ihnatenko, M. M. \& Sarapina, O. A. (2016). Sotsialno-ekonomichnyy potentsial silskykh terytoriy yak osnova rozvytku pidpryyemstv silskoho zelenoho turyzmu na zasadakh innovatsiynosti [Socio-economic potential of rural territories as a basis for development of rural green tourism enterprises on the basis of innovation]. Ekonomika i menedzhment kultury, 2, 32-38 (in Ukr.).

8. Romaniuk, I. A. (2016). Stratehichne upravlinnya rozvytkom haluzi turyzmu na zasadakh formuvannya korporatyvnoyi kultury turystychnykh pidpryyemstv [Strategic management of tourism development based on the formation of corporate culture of tourism enterprises]. Visnyk Berdyanskoho universytetu menedzhmentu i biznesu, 2 (34), 24-27 (in Ukr.).
9. Skryl, I. A. (2014). Sotsialnyy turyzm: sutnist, perevahy ta perspektyvy rozvytku [Social tourism: the essence, advantages and prospects of development]. Visnyk Kharkivskoho natsionalnoho universytetu, 824, 194-197 (in Ukr.).

10. Zadorozhna, K. I. (2016). Sotsialnyy turyzm u systemi turystychnoyi haluzi: kontseptualizatsiya ta intehratsiya [Social tourism in the tourism industry: conceptualization and integration]. Visnyk Chernivetskoho torhovelno-ekonomichnoho instytutu. Ekonomichni nauky, 2, 17-27 (in Ukr.).

11. Ihnatenko, M. M., Sarapina, O. A., Sakun, A. ZH., Marmul, L. O. \& Pylypenko, K. A. (2019). Models of implementation of enterprises in agricultural green tourism in European countries and assessment of their efficiency. International Journal of Innovative Technology and Exploring Engineering. 8, 12, 337-340 (in Eng.).

УДК 338.436

Н. В. Рунчева,

\section{ДЕРЖАВНА ПІДТРИМКА ЕКОНОМІЧНОЇ БЕЗПЕКИ ПІДПРИЕМСТВ АГРАРНОГО СЕКТОРУ}

Анотація. У статті наведені результати дослідження щодо державної підтримки економічної безпеки підприємств аграрного сектору. Надано особливості регуляторного впливу держкави на сталий розвиток аграрних підприємств, обгрунтовано систему інструментів управління економічною безпекою аграрних підприємств, динамічні особливості їх застосування залежно від загроз зовнішнього середовища.

Ключові слова: державна підтримка, економічна безпека, аграрний сектор, агропідприємство.

Summary. The article presents the results of the study on state support for economic security of agricultural enterprises. The peculiarities of the regulatory influence of the state on the sustainable development of agricultural enterprises are given, the system of instruments for managing the economic security of agricultural enterprises, the dynamic features of their application depending on environmental threats are substantiated.

Key words: state support, economic security, agrarian sector, agribusiness.

$$
\text { DOI : 10.33783/1977-4167-2019-46-2-75-79 }
$$

Постановка проблеми. Високий рівень розвитку сільськогосподарських підприємств характеризується пріоритетними цілями в забезпеченні економічної безпеки аграрного сектору, що $\mathrm{\epsilon}$ основою для підвищення конкурентоспроможності аграрної продукції регіону на зовнішньому та внутрішньому ринках.
Аналіз останніх досліджень і публікацій. Дослідження стану економічної безпеки аграрного сектору свідчать про необхідність розроблення заходів боротьби $з$ економічними загрозами, що сприятиме стійкому розвитку цієї сфери відтворення. Вітчизняні вчені: О. І. Гойчук [1], Ю. Я. Лузан [2], Т. І. Ткачук [3],

Бібліографія ДСТУ 8302:2015:

Рунчева Н. В., Горяча О. Л., Семенов К. О. Державна підтримка економічної безпеки підприємств аграрного сектору. Вісник Бердянського університету менеджменту і бізнесу. 2019. № 2 (46). С. 75-79.

References (APA):

Runcheva, N. V., Horiacha, O. L., Semenov, K. O. (2019). Derzhavna pidtrymka ekonomichnoi bezpeky pidpryiemstv ahrarnoho sektoru [State support to economic security of enterprises of agricultural sector]. Visnyk Berdianskoho universytetu menedzhmentu i biznesu, 2 (46), 75-79 (in Ukr.). 
М. Г. Чумаченько [5] присвятили свої дослідження цій проблемі.

Мета статті - обгрунтувати прикладний інструментарій регуляторного управління економічною безпекою аграрних підприємств; це $є$ основою для підвищення конкурентоспроможності аграрної продукції регіону на зовнішньому та внутрішньому ринках.

Виклад основного матеріалу дослідження. Для забезпечення економічної безпеки підприємств аграрного сектору держави необхідно передусім у найкоротший термін забезпечити фінансову самодостатність агропідприємств реального сектору економіки за рахунок зменшення податкового тягара і створення передумов для поповнення власних оборотних коштів та створити умови для своєчасного відновлення основних виробничих фондів агропідприємства за рахунок кредитних коштів, що забезпечить необтяжливе залучення кредитних банківських позичок. Крім того, для забезпечення безперешкодного переливання капіталу з реального сектору у фінансовий сектор і навпаки, а також припинення спекулятивних операцій у фінансовому секторі економіки, що відволікає величезні кошти від виробництва, це дозволить вирівняти в рентабельності результативність діяльності в обох секторах економіки та визначити точки економічного зростання, концентрацію інвестицій, що дасть швидку віддачу, забезпечить високу зайнятість і безперешкодний збут продукції. Такими точками зростання можуть бути:

- підприємства харчової промисловості;

- повернення заробітній платні працівників відтворювальної і функцій стимулювання, без яких заробітна платня виконує функцію допомоги з безробіття, не виступаючи фактором зростання продуктивності праці;

- не допускати, щоб питома вага заробітної платні з усіх видів доходів працівників знижувалась більш як на 30 \%, що також робить цей розподільний механізм спрямованим не на ефективну участь у виробництві, а на всілякі побічні заробітки;

- бюджетна сфера повинна жити за своїми коштами, вирішивши проблему прийняття бездефіцитних бюджетів;

- підсилити регулятивну роль митної служби 3 метою захисту вітчизняного агровиробника і національного ринку, для чого не вважати головною функцією митниці фіскальну.

Для ліквідації негативних наслідків загроз економічній безпеці підприємств аграрного сектору в обіговій сфері державі необхідно вжити таких заходів:

- поряд 3 ринковими механізмами формування цін на товари і послуги ввести державне регулювання цін на продукцію природних монополій (газ, нафта, електроенергія, залізничні й інші тарифи);
- зміцнити захист прав споживачів за допомогою подальшого удосконалення нормативноправової бази захисту економічних інтересів населення.

Наразі для забезпечення сталого розвитку сільськогосподарського виробництва і вирішення завдань економічної безпеки аграрного сектору державі необхідно вжити таких заходів у сфері споживання:

- розробити концепцію і механізми керування соціальним розвитком, що не тільки б підпорядкували економічний розвиток аграрного комплексу соціальним цілям і завданням, але і дали б можливість перейти на траєкторію сталого розвитку;

- створити спеціалізовані регіональні інститути економічної безпеки з особливими правами і повноваженнями, коли експерти інституту могли б призначати доцільність прийнятих економічних рішень і визначати загрози економічної безпеки в регіоні.

Окрім того, пропонуються заходи з удосконалення системи і механізмів державної підтримки розвитку сільських територій та аграрного виробництва відповідно до вимог СОТ і стандартів ЄC в напряму переорієнтації державної підтримки від підтримки цін до організації дешевшого виробництва і маркетингу, за допомогою яких можна реалізувати принципи економічної безпеки аграрного сектору.

Сучасний рівень державної підтримки підприємств аграрного сектору в Україні є недостатнім. Значне державне втручання спрямоване на зведення до мінімуму існуючого впливу ринкових механізмів на галузь (табл.1).

Проте проблема державної підтримки сільськогосподарських товаровиробників в Україні ускладнилася у зв'язку з приєднанням нашої країни до світової організації торгівлі (СОТ). За правилами СОТ, бюджетна підтримка поділяється на заходи «зеленої скриньки» (green box policies), які звільнено від зобов'язань зі скорочення, та заходи «жовтої скриньки» (amber box policies), які мають бути скорочені. До заходів «жовтої скриньки» в Україні належать:

- здешевлення кредитів комерційних банків;

- фінансова підтримка фермерських господарств;

- фінансова підтримка виробництва продукції тваринництва і рослинництва; закладення молодих садів, виноградників;

- часткова компенсація вартості техніки і мінеральних добрив;

- здійснення фінансової підтримки розвитку підприємств молочної переробки;

- аграрний фонд.

Для вітчизняного аграрного сектору економіки нині актуальним завданням є нарощуван- 
Основні показники діяльності підприємств аграрного сектору України (розробка автора за даними [4])

\begin{tabular}{|c|c|c|c|c|c|c|c|}
\hline \multirow{2}{*}{$\begin{array}{l}\text { № } \\
\text { 3/ח }\end{array}$} & \multirow{2}{*}{ Показник } & \multicolumn{5}{|c|}{ Роки } & \multirow{2}{*}{$\begin{array}{c}\text { Відхилення } \\
\text { 2018/2014 pp., +,-- }\end{array}$} \\
\hline & & 2014 & 2015 & 2016 & 2017 & 2018 & \\
\hline 1 & $\begin{array}{l}\text { Фінансовий результат } \\
\text { до оподаткування, млн } \\
\text { грн }\end{array}$ & 21495,9 & 101996, & 90122,1 & 68606,5 & 67170,8 & $+45674,9$ \\
\hline 2 & $\begin{array}{l}\text { Чистий прибуток (зби- } \\
\text { ток), млн грн }\end{array}$ & 2143,4 & 101912, & 89816,3 & 68276,8 & 66878,1 & $+64734,7$ \\
\hline 3 & $\begin{array}{l}\text { Рівень рентабельності } \\
\text { всієї діяльності, \% }\end{array}$ & 9,3 & 30,4 & 25,6 & 16,5 & 13,5 & $+4,2$ \\
\hline 4 & $\begin{array}{l}\text { Рівень рентабельності } \\
\text { операційної діяльнос- } \\
\text { ті, \% }\end{array}$ & 21,4 & 43,0 & 33,6 & 23,2 & 18,5 & $-2,9$ \\
\hline 5 & $\begin{array}{l}\text { Кількість найманих } \\
\text { працівників, тис. осіб }\end{array}$ & 528,9 & 500,9 & 513,2 & 489,2 & 474,6 & $-54,3$ \\
\hline
\end{tabular}

ня обсягів виробництва сільськогосподарської продукції. Зазначимо, що країни Європейського Союзу (ЕС) вирішували таке завдання у 60-х рр. минулого століття. Для забезпечення зростання виробництва сільськогосподарської продукції вони активно використовували цінову підтримку, що належить до «жовтої скриньки». Так, на кінець 1960-х рр. загальна ціна у країнах ЄС на пшеницю перевищувала середньосвітовий рівень майже удвічі, на білий цукор і сухе молоко - у 3,6 разів, на тваринне масло у 5 разів; на рис, кукурудзу, на м'ясо і рослинну олію - у $1,4-1,8$ рази. Завдяки такій бюджетній підтримці виробництво зростало настільки стрімко, що наприкінці 1960 р. практично з усіх продуктів виникли надлишки. На сучасному етапі для розвинених країн нагальною проблемою є скорочення обсягів виробництва і, відповідно, для них $€$ доцільним зменшення бюджетної підтримки через ходи «жовтої скриньки».

Пріоритетними щодо державного впливу на аграрний сектор України через бюджетну політику прогнозуються напрями, що класифікуються за правилами СОТ, як такі, що не підлягають скороченню:

- підтримка доходів виробників сільськогосподарської продукції, що не пов’язана з виробництвом;

- відшкодування збитків від стихійних лих;

- створення державних резервів для забезпечення продовольчої безпеки;

- структурна перебудова через вилучення природних ресурсів із сільськогосподарського виробництва та через державні інвестиції на фінансову та фізичну реструктуризацію виробничої діяльності;

- інспектування і перевірка окремих продуктів для виявлення відповідності нормам охорони зоров'я, безпеки, рівня якості та стандартів (утримання установ державної ветеринарної медицини, державних насіннєвих інспекцій, державних сортовипробувальних станцій, державних хлібних інспекцій тощо);

- послуги з маркетингу і просування товарів на ринок;

- боротьба зі шкідниками і хворобами сільськогосподарських рослин та тварин;

- розвиток інфраструктури на селі: будівництво мереж забезпечення електроенергією, доріг та інших транспортних споруд, ринкових і портових споруд, потужностей для водозабезпечення, гребель та дренажних систем, а також інфраструктурні роботи, пов'язані з охороною навколишнього середовища;

- підтримка регіональних програм надання допомоги (допомога надається регіонам, які є неблагополучними на основі об'єктивних критеріїв, зокрема за складними кліматичними умовами);

- внутрішня продовольча допомога знедоленим верствам населення;

- поширення досвіду та консультаційні послуги;

- загальні науково-дослідні роботи та розвиток науково-дослідних програм щодо окремих видів продукції;

- підготовка, перепідготовка і підвищення кваліфікації спеціалістів та робітничих кадрів для виробничої і соціальної сфер села;

- охорона навколишнього середовища.

Розроблені пропозиції можуть грунтуватися на розрахунках бюджетної підтримки розвитку аграрного виробництва, інфраструктури та механізмів аграрного ринку. Серед напрямів бюджетної підтримки виробничої діяльності, розміри якої підлягатимуть скороченню згідно з вимогами СОT, передбачаються:

- інноваційний розвиток галузі, насамперед селекція у рослинництві, тваринництві та птахівництві;

- упровадження високих технологій у виробництві й переробленні сільськогосподарської продукції; 
- виробництво нових видів енергоресурсів, упровадження технологій аграрного землеробства, енергозберігаючих технологій;

- інвестиційна діяльність, зокрема відтворення сучасної виробничої інфраструктури (меліоративних систем, підприємств із перероблення та зберігання сільськогосподарської продукціі);

- розвиток нових виробництв на основі місцевих ресурсів та малого підприємництва у сільській місцевості;

- створення високотехнологічного товарного виробництва;

- часткова компенсація відсотків за коротко- та середньостроковими кредитами, залученими підприємствами агропромислового комплексу, які не спрямовуються на конкретну підтримку окремих видів продукції чи підприємств;

- забезпечення підприємств агропромислового комплексу сільськогосподарською технікою через часткову компенсацію іiі вартості та стимулювання розвитку фінансового лізингу;

- часткова компенсація вартості матеріально-технічних ресурсів, що споживаються виробниками сільськогосподарської продукції;

- підтримка виробництва продукції тваринництва та рослинництва, яка залежатиме від виду та обсягів виробництва;

- часткова компенсація витрат виробників сільськогосподарської продукції при сплаті внесків до фондів соціального та пенсійного страхування.

Скорочення обсягів державної підтримки 3 вищезазначених напрямів не відбуватиметься, якщо вони не будуть справляти спотворюючого впливу на торгівлю чи виробництво, або такий вплив буде зведений до мінімуму.

3 метою удосконалення механізмів забезпечення фінансовими ресурсами соціально-економічного розвитку села пропонується:

- запровадження науково обгрунтованих ефективних механізмів і інструментів фінансової підтримки на основі принципів рівності форм господарювання;

- збільшення обсягів фінансування суспільних благ, зокрема на сільськогосподарські дослідження і розробки, дорадчі служби, освіту, соціальну інфраструктуру, системи контролю за безпечністю та якістю продуктів харчування і розвиток сільської місцевості;

- підвищення ефективності видатків державного бюджету для підтримки аграрного сектору економіки шляхом упровадження методології програмно-цільового методу формування та виконання бюджету;

- запровадження моніторингу виконання бюджетних програм, критеріїв і процедур щодо скасування неефективних програм та переведення фінансових ресурсів на програми, які найбільше відповідають цілям державної підтримки;

- розроблення умов та механізмів розширення часткового бюджетного фінансування пріоритетних напрямів сільськогосподарського виробництва та ін. [5, с. 11].

Забезпечення економічної безпеки підприємств аграрного сектору через податкову політику передбачається за допомогою удосконалення податкового інструментарію з метою забезпечення сприятливих умов для функціонування сільськогосподарських товаровиробників різних організаційно-правових форм, а саме:

- поступового обмеження подальших перспектив застосування спеціальних режимів оподаткування;

- напрями адаптації податкових інструментаріїв до кращого зарубіжного досвіду оподаткування виробників галузі та з урахуванням вимог СОТ і директив EC;

- формування механізмів прямого та непрямого оподаткування з урахуванням конкурентоспроможності аграрного сектору на внутрішньому та зовнішньому ринках.

Пропонуються основні напрями реалізації податкової політики:

У сфері прямого оподаткування:

- збереження дії спецрежиму прямого оподаткування - фіксованого сільськогосподарського податку (ФСП), який об'єднує у собі низку прямих податків і забезпечує спрощення податкових відносин у галузі та запровадження після закінчення терміну дії ФСП нового сільськогосподарського податку, який об'єднає в собі земельний податок, інші податкові платежі та податок на прибуток;

- передбачення спеціального спрощеного режиму прямого оподаткування для суб’єктів малого і середнього бізнесу з метою стимулювання їх розвитку в сільській місцевості;

- розроблення спеціального податкового інструментарію для оподаткування сільськогосподарських підприємств індустріального типу;

- посилення ролі земельного податку в системі прямого оподаткування, вдосконалення методики визначення його бази з метою відображення реальних розмірів рентних доходів та обгрунтування оптимального розміру ставок для сільгоспвиробників усіх форм власності і господарювання;

У сфері непрямого оподаткування:

- відмова від непрямих методів підтримки сільськогосподарського виробництва за допомогою використання спеціальних податкових механізмів, зокрема поетапна переорієнтація порядку оподаткування доданої вартості (ПДВ) з продажу молока і м'яса з форми дотацій, що виплачуються переробними підприємствами, на пряму бюджетну підтримку; 
- максимальне нівелювання впливу ПДВ на фінансовий стан підприємств галузі шляхом упорядкування бюджетного відшкодування 3 ПДВ, зокрема через запровадження бюджетної цільової програми, направленої на своєчасне відшкодування надмірно сплачених сум ПДВ, що своєю чергою дасть змогу точніше спрогнозувати надходження до бюджету країни від підприємств аграрного сектору в разі стабілізації їх розвитку.

Вочевидь, спираючись на організаційно-економічний механізм, система управління повинна забезпечувати тісний взаємозв'язок конкурентоспроможності підприємства 3 попитом, збутом і ефективністю виробництва, а також здійснювати комплексний вплив на певні об’єкти управління на всіх стадіях життєвого циклу підприємства і рівнях його управління [6, с. 38].

Висновки. Отже, економічна безпека аграрного сектору може бути гарантована як на мікроекономічному рівні - підприємства чи регіону, так і на макроекономічному, завдяки фінансовому контролю. Це відображається у вдосконаленні фіскально-податкової і фінансово-кредитної політики держави за відношенням до галузей сільськогосподарського виробництва, управлінні розвитком суспільно-економічних процесів та антикризової стратегії і тактики самих підприємств та управлінні їх економічною діяльністю, зокрема, в розрізі нарощення експортного потенціалу аграрного сектору.

\section{Література}

1. Гойчук О. І. Продовольча безпека в Україні і світі. К. : Наукметодцентр аграрної науки. 2003. $114 \mathrm{c}$.

2. Лузан Ю. Я. Розвиток державної підтримки аграрного сектора України в умовах членства в СОТ. Облік і фінанси АПК. 2008. №3. С. 4-10.

3. Ткачук Т. І. Глобальні аспекти продовольчої проблеми. Аграрний вісник Причорномор'я. 2003. Вип. 22. С. 492-495.
4. Сільське господарство України за 2018 рік / Державна служба статистики України. URL : http://www.ukrstat.gov.ua/druk/publicat/kat_u/ 2019/zb/09/Zb_sg_2018\%20.pdf

5. Інвестиційна політика в Україні: досвід, проблеми, перспективи : моногр. / відпов. ред. М. Г. Чумаченко. Д : ІЕП НАН України. 2003. 392 с.

6. Мармуль Л. О. Оперативне управління конкурентоспроможністю, економічною безпекою та якістю продукції харчової промисловості. Економічна та продовольча безпека України. 2015. № $1-2$. C. $32-38$.

\section{References}

1. Ghojchuk, O. I. (2003). Ppodovoljchabezpeka $v$ Ukpajini i cviti [Food security in Ukraine and in the world]. Kyiv, Naukmetodcentp aghpapnoji nauky, 114 p. (in Ukr.).

2. Luzan, Ju. Ja. (2008). Pozvytok depzhavnoji pidtpymky aghpapnogho sektora Ukpajiny $v$ umovakh chlenctvav COT [Development of state support of the agrarian sector of Ukraine in the conditions of WTO membership]. Oblik i financy APK, 3, 4-10 (in Ukr.).

3. Tkachuk T. I. (2003). Ghlobaljni acpekty ppodovoljchoji ppoblemy [Global aspects of the food problem]. Aghpapnyj vicnyk Prychopnomop’ja, 22, pp. 492-495 (in Ukr.).

4. State Statistics Service of Ukraine (2018). Silske hospodarstvo Ukrainy za 2018 rik [Agriculture of Ukraine for 2018]. URL : http://www.ukrstat.gov.ua/druk/ publicat/kat_u/2019/zb/09/Zb_sg_2018\%20.pdf.

5. Chumachenko M. Gh. (ed.) (2003). Invectycijna polityka v Ukpajini: docvid, ppoblemy, pepcpektyvy [Investment policy in Ukraine: experience, problems, prospects]. Donetsk, AEN Ukraine. 392 p. (in Ukr.).

6. Marmul L. O. (2015). Operatyvne upravlinnja konkurentospromozhnistju, ekonomichnoju bezpekoju ta jakistju produkciji kharchovoji promyslovosti [Operational management of the competitiveness, economic security and quality of food products]. Ekonomichna ta prodovoljcha bezpeka Ukrajiny, 1-2, 32-38 (in Ukr.). 


\title{
УДОСКОНАЛЕННЯ ІНСТИТУЦЙНИХ ЗАСАД РОЗВИТКУ ТА ПІДВИЩЕННЯ КОНКУРЕНТОСПРОМОЖНОСТІ АГРАРНИХ ПІДПРИЕМСТВ
}

\begin{abstract}
Анотація. У статті розглянуті проблеми та перспективи розвитку інституційного забезпечення аграрних підприємств у контексті їх впливу на конкурентоспроможсність. При цьому виявлені особливості та складники інституційного забезпечення. Як вузькі місия вказано на недостатній розвиток громадських організацій та професійних об'єднань в агросфері. Виявлено ментальні особливості населення, які впливають на організацію інститутів та конкурентоспроможність аграрного виробництва. Це дозволило обгрунтувати концептуальні засади та визначити напрями й засоби удосконалення інституційного забезпечення аграрних підприємств з метою підвищення їх конкурентоспроможності.

Ключові слова: аграрні підприємства, інституційні засади, конкурентоспроможність, забезпечення, підвищення, ментальні особливості, громадські організації.
\end{abstract}

Summary. The article studies the problems and prospects of development of institutional support for agricultural enterprises in the context of their influence on competitiveness. It identifies characteristics and components of institutional support. As a weak point there was indicated a lack of development of public organizations and professional associations in the agro-sphere. There were revealed mental features of the population which influence organization of institutes and competitiveness of agricultural production. This made it possible to justify the conceptual framework and to determine the directions and means of improving the institutional support of agricultural enterprises in order to increase their competitiveness.

Key words: agricultural enterprises, institutional framework, competitiveness, support, increase, mental features, public organizations.

$$
\text { DOI : 10.33783/1977-4167-2019-46-2-80-84 }
$$

Постановка проблеми. Питання інституційного забезпечення мають основоположне значення для функціонування та розвитку аграрних підприємств. Саме різноманітні інститути регламентують їх діяльність, формують середовище здійснення агробізнесу, впливають на поведінку на ринку, ділову репутацію, конкурентоспроможність. При цьому динамічний розвиток аграрного виробництва, інших видів діяльності, дигіталізація та інші інновації, у т. ч. в управлінні, спричиняють та спонукають до постійного розвитку та удосконалення інституційних засад діяльності аграрних підприємств. Своєю чергою, інститути є чинниками конкурентоспроможності. Проте в такому розумінні, на відміну від спеціалізації виробництва, показників ресурсокористування, рентабельності, собівартості продукції, обсягів продаж, вони розглядаються не досить часто. Тому вказана тематика досліджень є актуальною та своєчасною.

Аналіз останніх досліджень і публікацій. Питання формування та розвитку інституційних за- сад функціонування аграрних підприємств висвітлені у працях М. Маліка, І. Романюк, Н. Рунчевої, О. Шпикуляка. Різні аспекти забезпечення та підвищення конкурентоспроможності суб'єктів агробізнесу досліджувалися В. Грановською, М. Ігнатенком, Ю. Кириловим, Л. Мармуль. Однак їх вивчення та оцінювання у взаємозв'язку потребують подальших розробок.

Мета статті - визначити чинники формування, особливості та складників інституційного забезпечення функціонування аграрних підприємств та розроблення концептуальних засад і практичних пропозицій щодо його удосконалення стосовно впливу на підвищення конкурентоспроможності аграрного виробництва.

Виклад основного матеріалу дослідження. Розвиток великих, середніх та малих аграрних підприємств як системи інституцій, які впливають на внутрішню структуру організації сільськогосподарської діяльності у процесі обміну ресурсами та результатами їх переробки, підвищення їх

(C) О. Г. Семененко, О. А. Горбатенко, 2019

Бібліографія ДСТУ 8302:2015:

Семененко О. Г., Горбатенко О. А. Удосконалення інституційних засад розвитку та підвищення конкурентоспроможності аграрних підприємств. Вісник Бердянського університету менеджменту і бізнесу. 2019. № 2 (46). С. 80-84.

References (APA):

Semenenko, O. H., Horbatenko, O. A. (2019). Udoskonalennia instytutsiinykh zasad rozvytku ta pidvyshchennia konkurentospromozhnosti ahrarnykh pidpryiemstv [Improvement of institutional framework for development and increase of competitiveness of agricultural enterprises]. Visnyk Berdianskoho universytetu menedzhmentu i biznesu, 2 (46), 80-84 (in Ukr.). 
конкурентоспроможності неможливий без належного інституційного забезпечення. Для того, щоб побудувати цілісну концепцію підвищення ефективності й конкурентоспроможності аграрних підприємств, ураховуючи досвід попередніх трансформацій, потрібно оцінювати інституційні умови їх функціонування сьогодні, тобто рівень достатності інституційної забезпеченості процесу розвитку суб'єктів господарювання аграрної сфери.

Як вказують науковці, зокрема, М. Ігнатенко, Н. Рунчева, інституційне забезпечення розвитку аграрних підприємств складають владні інститути, 3МІ, навчальні заклади, сільські громади, сільські родини та їх діяльність і процеси взаємодії і впливу на безперервне формування середовища, яке найбільшою мірою сприяло б самоорганізації аграрних суб'єктів господарювання. Вони являють собою складні комплекси функціонуючих елементів [1]. Тобто, це динамічний вплив на розвиток аграрних господарств організацій, інституцій у певному синергетичному взаємозв'язку.

Формування системи інституційного забезпечення розвитку великих аграрних підприємств передбачає упорядковану сукупність формальних і неформальних інституцій, що визначають та регулюють його територіальні, соціальні, виробничо-економічні, екологічні, нормативно-правові й організаційно-управлінські параметри. Складові інституційного середовища визначають пріоритети в рамках триєдиної системи соціально-економічних, законодавчих або політичних інституцій формального змісту та неформальних ідеологічних інституцій.

Як вказує А. Постол, правління розвитком великих аграрних підприємств в Україні представлено двома механізмами: державним та громадським. Вважаємо, що саме дисбаланс у їхніх повноваженнях і породжує низьку, а то й від'ємну якість інституцій. Недостатні повноваження механізму громадського управління є також наслідком його неформального підпорядкування першому [2].

На думку Л. Мармуль та І. Романюк, саме організована взаємодія та протидія самодостатніх елементів громадського та державного управління повинні формувати ефективне інституційноуправлінське забезпечення розвитку аграрних підприємств в умовах демократизації діяльності, ринкової конкуренції та зростаючої соціальної нерівності на селі [3]. Особлива роль при цьому має належати громадському контролю, сільським громадам як інструментам регулювання.

Громадський механізм контролю в аграрній сфері країни представлений через різноманітні об'єднання. Об'єднання аграріїв є формою залучення суб'єктів господарювання до процесу управління на всіх стадіях сільськогосподарсько- го відтворення. Адже конкурентоспроможність та ефективність потребує в сучасних умовах формування потужного середнього класу підприємців, який має стати основою їх збереження та підвищення. Рівень розвитку громадських організацій агросфери є індикатором становлення ліберальних відносин у ній.

Згідно з оприлюдненими даними, 73,0 \% аграрних підприємств не беруть участі у громадських або професійних об’єднаннях та спілках. Між тим їх задекларовано тут понад 100. Лише кожне четверте підприємство є членом ділових або професійних об'єднань (з-поміж середніх підприємств - кожне третє, серед великих - кожне друге підприємство) [4]. При цьому керівники підприємств, які не є членами об'єднань, вважають, що не отримають від членства вигоди і не бажають витрачати на це час та грошові кошти. Однією $з$ найважливіших проблем становлення аграрних відносин як ринкових є так і несформоване інституційне забезпечення прав власності на основний ресурс здійснення аграрної діяльності - землю.

Для країни характерна певна специфіка формування й збереження ефективності й конкурентоспроможності сільськогосподарської діяльності. Вона характеризується ментально-психологічними факторами, які пронизують усі іiі складові.

Серед них виокремлюють:

1) дефіцит соціальної відповідальності суб'єктів аграрних відносин;

2) поляризацію майнового стану, суспільних настроїв населення сільських територій;

3) низький рівень підприємницької та суспільної активності сільських жителів;

4) недовіру вітчизняного споживача до показників маркування якості продовольчої продукції;

5) значну індивідуалізацію суб'єктів підприємницької діяльності й відсутність інноваційного та конкурентного мотивів малих і дрібних підприємців-аграріїв через зневіру у своїх можливостях.

Метою удосконалення інституційного забезпечення ефективності й конкурентоспроможності аграрних підприємств повинно стати створення умов для становлення в Україні моделі сталого, багатофункціонального сільського господарства, яке разом з виробництвом якісного і безпечного продовольства, сировини й енергії задовольняло б інші потреби населення та надавало б суспільні послуги, спрямовані на формування якісного життєвого середовища та створення умов для зайнятості у сільській місцевості, зміцнення місцевих громад, збереження довкілля, традиційних сільських ландшафтів і біорізноманіття.

Пріоритетні завдання удосконалення інституційного забезпечення конкурентоспроможності й ефективності функціонування великих 
аграрних підприємств можуть бути визначені як такі, що створюють умови для реалізації найважливіших функцій підприємництва з цією метою: новаторської, організаційної, господарської, соціальної, особистісної (табл. 1).
Розроблення заходів, орієнтованих на досягнення означених завдань, повинно будуватися на принципах дотримання засад рівноважного й збалансованого розвитку бізнес-середовища. Серед них чільне місце посідають засоби та принципи

Пріоритетні завдання удосконалення інституційного забезпечення й підвищення

Таблиия 1 конкурентоспроможності аграрних підприємств

\begin{tabular}{|c|c|}
\hline $\begin{array}{l}\text { Реалізація функцій } \\
\text { підприємництва }\end{array}$ & Зміст \\
\hline \multirow{6}{*}{$\begin{array}{l}\text { Господарсько- } \\
\text { організаційна }\end{array}$} & $\begin{array}{l}\text { Збільшення кількості суб’єктів підприємницької діяльності, підвищення рівня ділової } \\
\text { активності }\end{array}$ \\
\hline & $\begin{array}{l}\text { Поліпшення ресурсного та матеріально-технічного забезпечення суб’єктів підприєм- } \\
\text { ництва }\end{array}$ \\
\hline & $\begin{array}{l}\text { Підвищення рівня ефективності фінансово-господарської діяльності та посилення } \\
\text { мотивації сільських жителів до підприємницької діяльності }\end{array}$ \\
\hline & $\begin{array}{l}\text { Активізація інтеграційних та кооперативних процесів між суб’єктами малого підприєм- } \\
\text { ництва аграрної сфери та іншими секторами економіки }\end{array}$ \\
\hline & Зниження трансакційних витрат суб’єктів підприємницької діяльності \\
\hline & Забезпечення протидії рейдерству та протиправному захопленню майна \\
\hline \multirow{3}{*}{ Новаторська } & Збільшення частки інноваційної продукції, виробленої підприємствами \\
\hline & Розбудова інформаційно-консультативної інфраструктури \\
\hline & Удосконалення структури й діяльності служби дорадництва \\
\hline Соціальна & $\begin{array}{l}\text { Зростання забезпеченості: школами, дитсадками, лікарнями, культурними закладами, } \\
\text { автошляхами, Internet, телекомунікаціями }\end{array}$ \\
\hline \multirow{3}{*}{ Особистісна } & Збільшення доходів від підприємницької діяльності \\
\hline & Особистісне зростання мешканців сільських територій \\
\hline & Збільшення привабливості сільського способу життя \\
\hline
\end{tabular}

соціальної відповідальності. Зокрема, ідеться про добровільність; інтегрованість у бізнес-процеси та бізнес-стратегіi; системність; користь для всіх заінтересованих сторін: працівників, споживачів, акціонерів, громади тощо, а також для підприємства; забезпечення внесків у вирішення екологічних, соціальних та інших проблем сталого розвитку [5].

Основними принципами повинні бути прозорість і відкритість будь-яких господарських, організаційних чи управлінських процедур; від- мова від підтримки діяльності конкретних підприємств чи груп підприємств; усунення будьякої суб'єктивності щодо реагування влади на діяльність окремого суб'єкта підприємницької діяльності; підтримка саморегульованості і конкурентності у ринковому середовищі (табл. 2).

Основні напрями реалізації завдань інституційного забезпечення ефективності й конкурентоспроможності аграрних підприємств наведено в узагальненому вигляді на рис. 1.

Таблиия 2

Основні принципи удосконалення інституційного забезпечення й підвищення конкурентоспроможності великих аграрних підприємств

\begin{tabular}{|l|l|}
\hline \multicolumn{1}{|c|}{ Принципи } & \multicolumn{1}{|c|}{ Зміст } \\
\hline $\begin{array}{l}\text { Опосередкованість впливу } \\
\text { регуляторного рішення }\end{array}$ & $\begin{array}{l}\text { Відмова від прямого впливу та підтримки діяльності конкретних підпри- } \\
\text { ємств чи груп підприємств }\end{array}$ \\
\hline $\begin{array}{l}\text { Врахування ефекту масштабу дії } \\
\text { регуляторного рішення }\end{array}$ & $\begin{array}{l}\text { Врахування економічної віддачі не від конкретно обраного підприємства, а } \\
\text { від масиву споріднених підприємств }\end{array}$ \\
\hline $\begin{array}{l}\text { Безособовість функціонування } \\
\text { органів державної влади }\end{array}$ & $\begin{array}{l}\text { Усунення будь-якої суб’єктивної вибірковості щодо реагування органами } \\
\text { державної влади на ринкову ситуацію чи діяльність окремого суб’єкта під- } \\
\text { приємницької діяльності }\end{array}$ \\
\hline $\begin{array}{l}\text { Саморегульованість у ринковому } \\
\text { середовищі }\end{array}$ & $\begin{array}{l}\text { Будь-який механізм регулювання не повинен вимагати додаткових регуля- } \\
\text { торних актів прямого впливу }\end{array}$ \\
\hline Прозорість і відкритість процедур & $\begin{array}{l}\text { Запропоновані дії мають бути вичерпно деталізовані і публічно встановлені } \\
\text { регулятором }\end{array}$ \\
\hline $\begin{array}{l}\text { Конкурентність заходів } \\
\text { стимулювання }\end{array}$ & Попередження нецінової конкуренції та захист прав споживачів \\
\hline
\end{tabular}




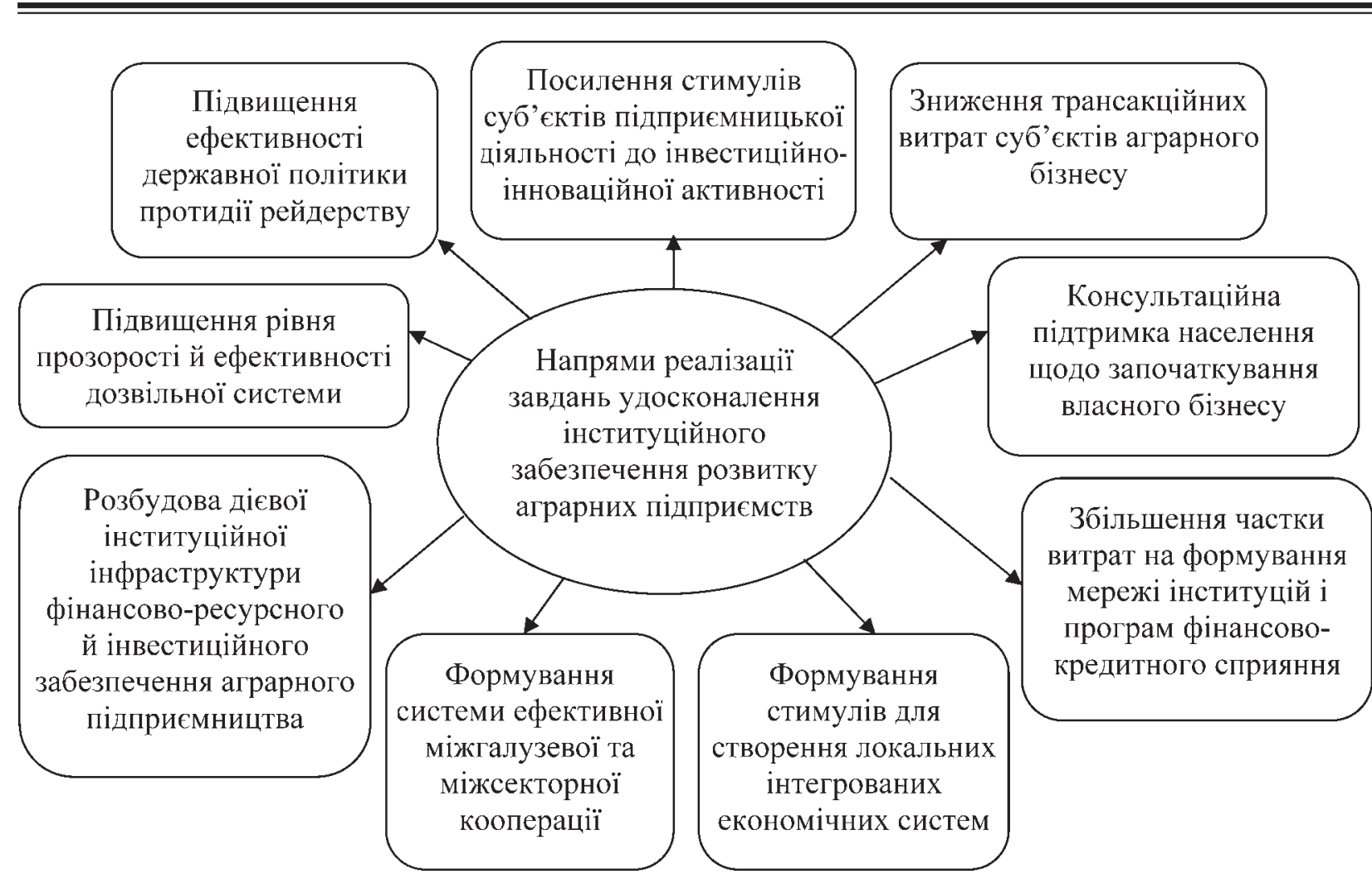

Рис. 1. Напрями реалізації завдань інституційного забезпечення й підвищення конкурентоспроможності аграрних підприємств

Як показує аналіз змісту відображених на рис. 1 напрямів, вони виконують переважно стимулюючі для розвитку агробізнесу функції. Це вказує на впровадження демократичних засад інституціалізму в агросферу.

Висновки. Удосконалення інституційного забезпечення аграрних підприємств через посилення його складових дозволить досягти позитивного соціально-економічного й екологічного ефектів. Вони можуть бути виражені у створенні організаційно-економічних умов для ефективного соціально спрямованого розвитку аграрних підприємств; забезпеченні підвищення конкурентоспроможності; раціональному використанні природних і трудових ресурсів; формуванні людського капіталу на селі; підтримці сільських громад. Ідеться також про стимулювання розвитку малих і середніх аграрних товаровиробників, дорадництво, розвиток сільських територій, забезпечення доступності інвестиційних ресурсів, удосконалення форм і методів державної підтримки через інструменти іiї прозорості, прогнозованості та системності.

\section{Література}

1. Ihnatenko M., Antoshkin V., Krukovska O., Malyshko V., Marmul L. Social investments as the highest manifestation of implementation of social responsibility of the companies of agribusiness. International Journal of Recent Technology and Engineering. 2019. Vol. 8. Iss. 3. C. 7124-7132.
2. Постол А. А. Розвиток великих аграрних підприємств: механізми та інструментарій : монографія. Харків : Смугаста типографія, 2018. 348 с.

3. Мармуль Л. О., Романюк І. А. Ринок праці та зайнятість населення сільських територій: теорія і практика регулювання. Херсон : Айлант, 2015. $266 \mathrm{c}$.

4. Романюк I. А. Особливості відтворювального процесу в аграрному секторі. Агросвіт. 2016. № 11. C. $12-15$.

5. Ігнатенко М. М. Стратегії та механізми управління розвитком соціальної відповідальності суб'єктів господарювання аграрної сфери економіки : монографія. Херсон : Айлант, 2015. 470 c.

\section{References}

1. Ihnatenko M., Antoshkin V., Krukovska O., Malyshko V., Marmul L. Social investments as the highest manifestation of implementation of social responsibility of the companies of agribusiness. International Journal of Recent Technology and Engineering. 2019. Vol. 8. Iss. 3. C. 7124-7132.

2. Postol, A. A. (2018). Rozvitok velikih agrarnih pidpriyemstv: mehanizmi ta instrumentarij. [Evelopment of large agrarian pidpriyemstv: mechanisms of this instrument]. Harkiv, Smugasta tipografiya Publ. (in Ukr.).

3. Marmul, L. O. \& Romanyuk, I. A. (2015). Rynok pratsi ta zainiatist naselennia silskykh terytorii: teoriia i praktyka rehuliuvannia [Labor market and rural population employment: the theory and practice of regulation]. Kherson, Aylant Publ. (in Ukr.). 
4. Romanyuk, I. A. (2016). Osoblyvosti vidtvoriuvalnoho protsesu $v$ ahrarnomu sektori [Features of the reproduction process in the agrarian sector]. Ahrosvit, 11, 12-15 (in Ukr.).

5. Ihnatenko, M. M.(2015). Stratehiitamekhanizmy upravlinnia rozvytkom sotsialnoi vidpovidalnosti subiektiv hospodariuvannia ahrarnoi sfery ekonomiky [Strategies and mechanisms for managing the development of social responsibility of economic entities of the agrarian sector of the economy]. Kherson, Aylant (in Ukr.).

\section{ЗАКЛАДИ ЗДОРОВОГО ХАРЧУВАННЯ ЯК ПЕРСПЕКТИВНИЙ ТРЕНД РОЗВИТКУ РЕСТОРАННОГО БІЗНЕСУ}

Анотація. У статті досліджено сучасні світові тенденції розвитку закладів здорового харчування. Розглянуто динаміку потреб громадян США та СС у здоровому харчуванні та в закладах здорового харчування за 2012-2017 рр.. Встановлені світові лідери розвитку закладів здорового харчування. Визначено ключові проблеми, з якими стикаються відповідні заклади під час управління асортиментом послуг в умовах несприятливої кон'юнктури ринку.

Ключові слова: громадське харчування, слоуфуд, заклади харчування, заклади здорового харчування.

Summary. The article examines the current global trends in the development of healthy eating establishments. The dynamics of the needs of US and EU citizens in healthy nutrition and in healthy nutrition institutions in 2012-2017 are determined. Defined world leaders in the development of healthy eating establishments. The key problems that are faced by the respective institutions in the management of the range of services in adverse market conditions are identified.

Key words: catering, slow food, food, healthy eating places.

$$
\text { DOI : 10.33783/1977-4167-2019-46-2-84-88 }
$$

Постановка проблеми. У сучасних умовах пришвидшеного темпу життя у великих містах піклуватися про правильність харчування зазвичай немає часу. Проте популярність здорового способу життя в розвинених країнах планети неухильно зростає: зараз люди більш освічені, отже більше уваги звертають на властивості їжі. Їм вже недостатньо того, щоб продукт був просто смачним, вони хочуть знати, де і як саме він був вирощений та приготовлений. Таким чином, ресторани «здорового харчування» - черговий тренд у громадському харчуванні.

У світовій практиці 2016 р. ознаменувався збільшенням закладів здорового харчування, що зумовлено поганою екологією, проблемами ожиріння, міськими стресами і поширенням фастфудів. Люди дедалі більше уваги приділяють своєму тілу, самопочуттю і спорту, вони хочуть харчуватися правильно, але смачно.
Аналіз останніх досліджень і публікацій. Вивченню проблем та перспектив розвитку закладів здорового харчування приділено велику увагу в першу чергу закордонних науковців, а саме: Le Velly, R., Sassatelli, R., Schnepper, R., Schneider, T., Willems, K O. Праці цих учених надають достатню інформацію щодо особливостей та перспектив розвитку закладів здорового харчування, аналізуються чинники, що впливають на ринок громадського харчування у світі. Однак причинам розвитку цього напряму громадського харчування, визначенню факторів що найбільше на нього впливають, гендерним показникам прихильників такого виду закладів приділяється значно менше уваги і ця перспективна складова функціонування ресторанного бізнесу потребує додаткових досліджень.

Метою статті - проаналізувати ключові фактори, що впливають на розвиток закладів здорового харчування у світі.

(C) Д. І. Соловйов, В. С. Голодаєв, В. В. Дейнега, 2019

Бібліографія ДСТУ 8302:2015:

Соловйов Д. І., Голодаєв В. С., Дейнега В. В. Заклади здорового харчування як перспективний тренд розвитку ресторанного бізнесу. Вісник Бердянського університету менеджменту і бізнесу. 2019. № 2 (46). С. 84-88.

References (APA):

Soloviov, D. I., Holodaiev, V. S., Deineha, V. V. (2019). Zaklady zdorovoho kharchuvannia yak perspektyvnyi trend rozvytku restorannoho biznesu [Establishment of healthy food as a prospective trend of development of restaurant business]. Visnyk Berdianskoho universytetu menedzhmentu i biznesu, 2 (46), 84-88 (in Ukr.). 
Виклад основного матеріалу дослідження. Продовжуючи тему, вже в 2017 р. тенденція значно зміцнила позиціі. У світі з'явилося нове поняття «слоуфуд», що має на увазі задоволення смачними і корисними стравами. Овочі та фрукти стають у центрі столу, при цьому їх піддають мінімальній тепловій обробці, щоб зберегти натуральний смак. Нині 100000 людей по всій планеті є членами асоціації «слоуфуд» у 160 країнах світу; національні представництва працюють в Італії, Німеччині, Швейцарії, США, Японії, Великій Британії і Нідерландах. Завдяки цій тенденції в ресторанному бізнесі на вулицях міст планети з'являються салат-бари, суп-кафе, а кількість закладів, що пропонують вегетаріанські страви, постійно зростає [4, с. 23].

У Свропі практика державного втручання у сферу громадського харчування існує з кінця 90-х років XX ст. Так, в Італії кілька років тому діяла програма сертифікації якості їжі в місцевих закладах, так званий «Блакитний сертифікат».

Потреба в ній виникла у зв'язку з необхідністю зміцнити здоров’я нації шляхом прищеплення більш здорових звичок у їжі. Замислившись про правильність харчування, італійці стали віддавати перевагу ресторанам, позначеним «Блакитним сертифікатом», і частіше вживати в їжу фрукти, зелень і свіжу рибу. Одним зі світових лідерів розвитку закладів здорового харчування є США. Опитування жінок США показало, що здорове харчування впевнено лідирує в списку цінностей. Понад 60 \% назвали здоров'я важливим ніж сексуальні відносини. 70 \% опитаних 3 легкістю обміняли б хороші оцінки дитини на правильне харчування, 60 \% ні за що не згодні економити кошти, замінюючи продукти здорового харчування на більш дешеві аналоги. Понад 80 \% сказали, що здоровому тілу віддадуть перевагу прекрасному гардеробу, а 55 \% погодилися б відмовитися від кар'єрного зростання заради правильного харчування [5, с. 175]. Динаміку переваг громадян США в здоровому харчуванні в закладах громадського харчування показано на рис. 1.

Здорове харчування стає черговим масовим захопленням американців. Багато згодні витрачати великі гроші на суперпродукти. Для багатьох це стає головною цінністю життя.

Динаміку переваг громадян ЕС у здоровому харчуванні в закладах громадського харчування, а також дані Євростату зображено на рис. 2.

Варто зазначити, що в Європі висувають більш високі вимоги до якості і змісту їжі в закладах громадського харчування, ніж у США. Дана динаміка простежується як по сегменту «чоловіки», так і «жінки».

Говорячи про тенденції розвитку закладів здорового харчування, варто зазначити, що лідером є світова мережа тренду, названого «слоуфуд». На кінець 2016 р. закладів з вивіскою, яка зображує равлика, і написом «Slow Food» налічувалося 2373.

Спеціально для мережі розроблено інтернетдодаток для смартфонів - Slow Food Planet. Biн зберігає інформацію про всі ресторани мережі на планеті.

Другою за популярністю є мережа Freshii, канадська франшиза швидкого харчування, заснована в 2005 р., яка пропонує салати, роли та основні страви, більшість 3 яких становлять мен-

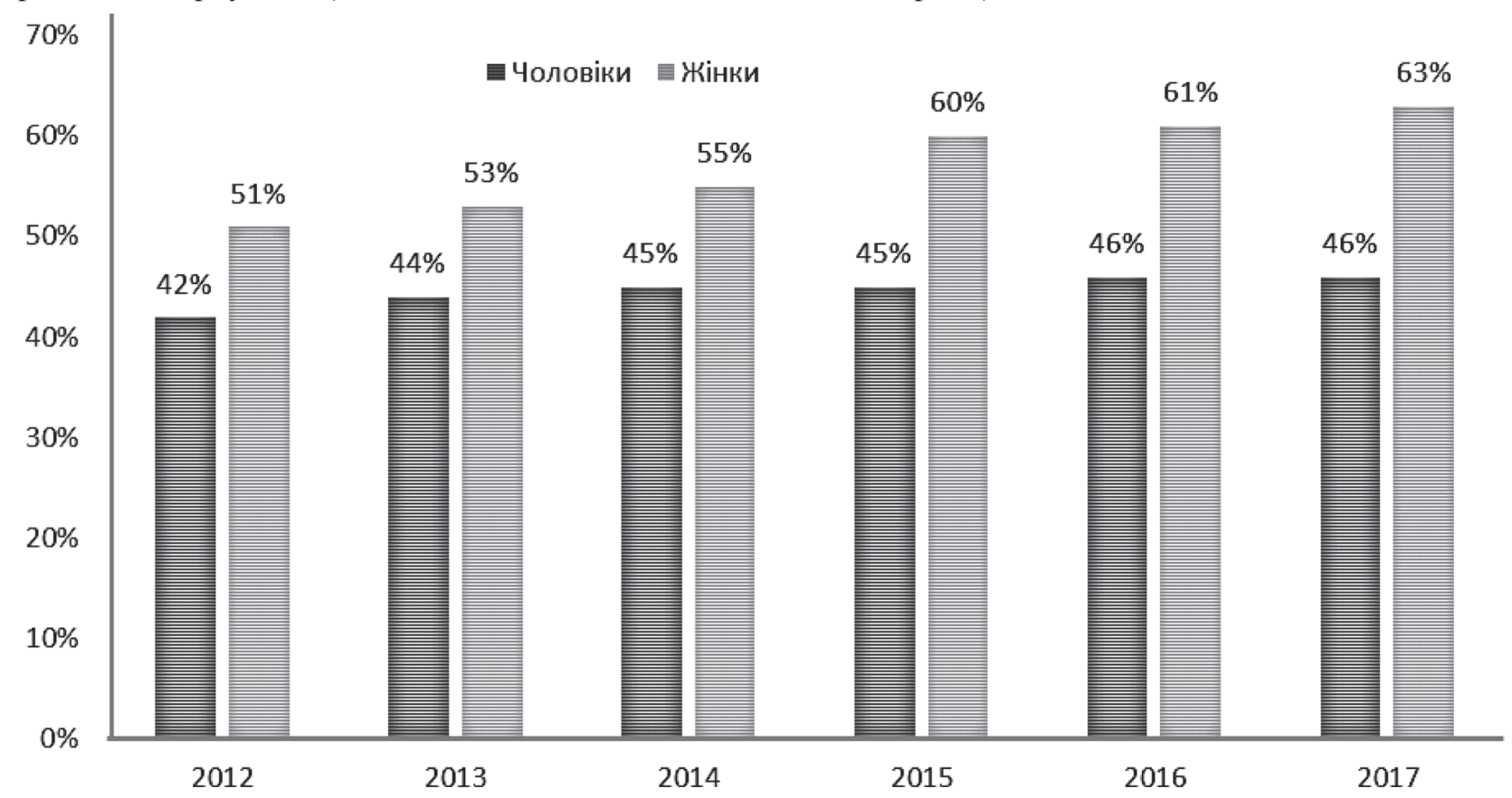

Рис 1. Динаміка потреби громадян США в здоровому харчуванні в закладах громадського харчування за 2012-2017 рр., \% (складено за даними [2]) 


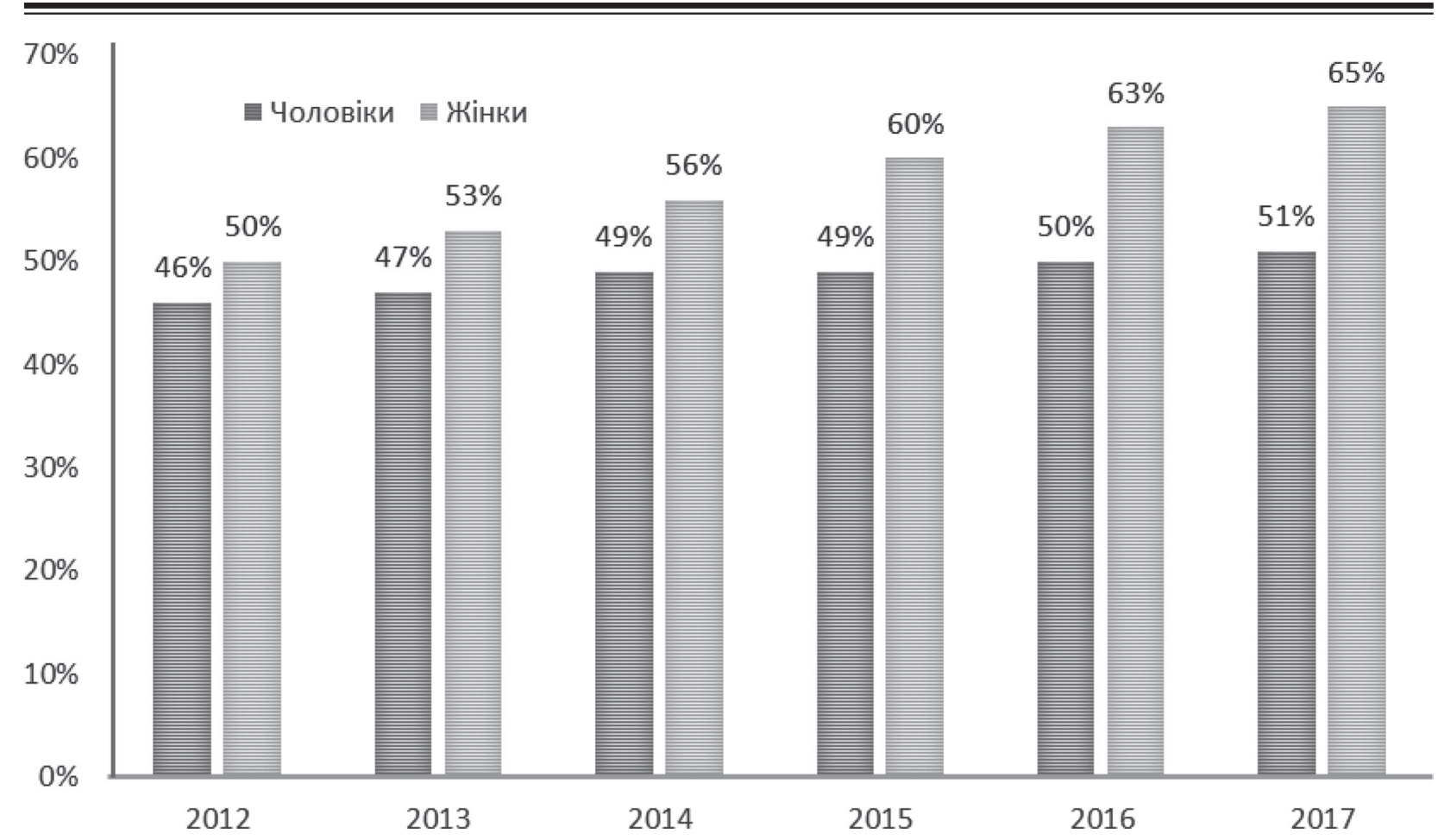

Рис. 2. Динаміка потреби громадян СС у здоровому харчуванні в закладах громадського харчування за 2012-2017 рр., \% (складено за даними [1])

ше 700 калорій і коштують не більше 7 дол. США за порцію. Мережа може похвалитися більш ніж 300 ресторанами по всьому світу і є однією з найпопулярніших у світі мереж здорового швидкого харчування. За останні кілька років нові філії відкрилися в різних аеропортах, стадіонах і великих супермаркетах.

Варто зазначити, що в 2015 році, після того, як McDonald's оголосив про свої зміни в меню щодо здорової їі, генеральний директор Freshii Метью Коррін відправив у корпорацію відкритого листа, пропонуючи співпрацю і спільне просування мереж, що рекомендують швидке здорове харчування. Нині ця пропозиція знаходиться в стадії розгляду й оцінювання перспектив упровадження.

Третім за кількістю філій є британський Pret a Manger. Найпопулярніша 3 мереж здорового харчування в Європі відкрилася в Лондоні в 1986 р. Аудиторія Pret a Manger - це офісні клерки. Саме на таких відвідувачів і орієнтувалися засновники мережі: вони хотіли, щоб сендвічі були свіжими і готувалися на місці, бажано з цільнозернового хліба, щоб у салатах і десертах не було неприємних харчових домішок, підсолоджувачів і консервантів і щоб завжди можна було купити свіжі соки.

Азія також не відстає від тенденцій здорового харчування. Найбільш популярний проєкт закладів здорового харчування даного регіону Mosburger (Японія). Це друга за величиною мережа підприємств швидкого харчування в Японії, найближчий японський конкурент «Макдоналдса» і лідер здорового харчування в Азії. Головний їх винахід - рисовий бургер, у якому традиційна булочка замінена на рисову з додаванням пшона і ячменю. Лінійка рисових бургерів доволі широка і включає в себе досить екзотичні варіанти з коренем лопуха і морквяним рисом, з куркою, тертим дайконом і соєвим соусом, з креветками і водоростями, з авокадо і васабі, а також з вугром.

У всіх філіях японської мережі використовується тільки якісна тасманійська яловичина i фермерські овочі. Кожен бургер має написану від руки табличку, в якій вказуються ім'я працівника, що його зробив, і назва ферми-постачальника інгредієнтів. Відвідувачі також поважають місцевий кукурудзяний суп.

Так само варто зазначити, що ринок закладів здорового харчування також має тенденцію до поділу за специфікацією. В різних сегментах ринок громадського харчування поводиться по-різному. Особливо швидкі темпи зростання кількості відвідувачів відзначають серед демократичних підприємств - закладів класу «casual» і «фаст-фуд». Вони користуються популярністю більш ніж у половини населення за доступність і швидке обслуговування.

Сегмент фаст-фуду демонструє доволі високу динаміку розвитку, за останні роки кількість закладів, які працюють у рамках даного формату, збільшилася на $20 \%$.

Динаміку зростання кількості закладів здорового харчування за останні роки головних світових торгових марок показано на рис. 3.

Одним із ключових елементів динамічного розвитку ресторанів здорової їі стала еволюція споживчої поведінки. У даному випадку нові переваги споживачів стали закликом до 


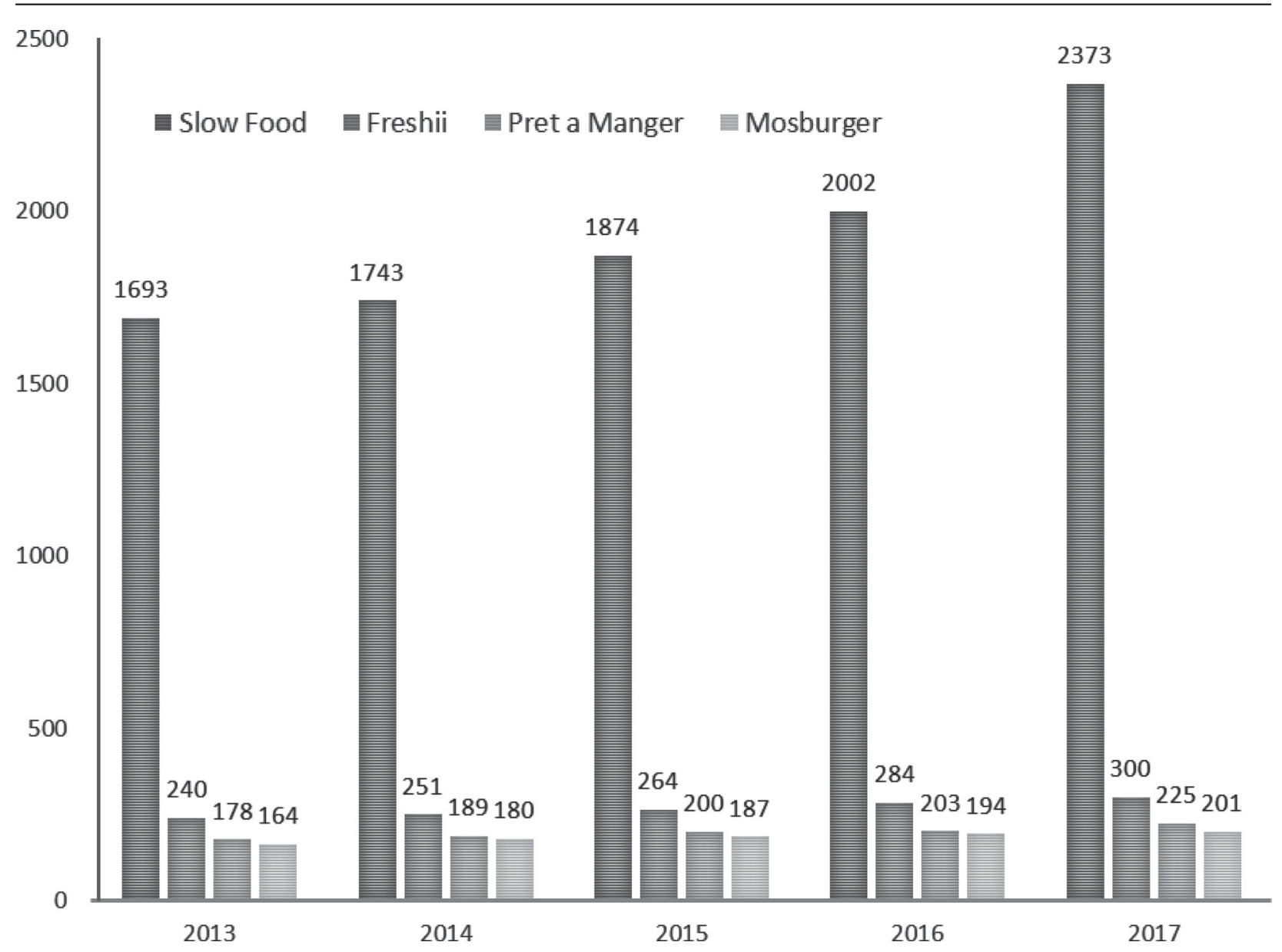

Рис. 3. Динаміка зростання кількості закладів здорового харчування за останні роки в основних світових торгових марок (складено за даними [2])

активності для виробників і роздрібних мереж. Деякі компанії вже відреагували на зміни в купівельній поведінці як у світі, так і в окремих іiі регіонах [6, с. 7]. Проаналізувавши активність компаній-лідерів громадського здорового харчування, можна виділити чотири основні шляхи, за якими вони пішли, задовольняючи потреби покупця:

- зміна порції і їі обмеження: компанії змінюють об'єм упаковки і вміст, вказуючи, що цей продукт слід споживати акуратно і час від часу;

- зміна рецептури і складу продукту: скорочення маси цукру, солі та жирів;

- розширення асортименту: скорочення цукровмісних продуктів і введення здорової продукції у свій портфель замовлень;

- зміна стратегії компанії з фокусом на продукти харчування, як на профілактичний засіб від хвороб.

Упроваджені компаніями практики показують, наскільки важливий споживачам тренд здорового харчування і способу життя.

Висновки. Аналіз світового ринку закладів здорового харчування підтвердив, що під час управління асортиментом послуг в умовах несприятливої кон'юнктури ринку дані компанії стикаються з двома основними складнощами:
1. Підтримка якості послуги. Якщо виключити негативний вплив цінових факторів, то падіння попиту веде до ускладнень з підтримання якості послуг через зниження мотивації і залучення в процес обслуговування клієнтів основного персоналу. Головних причин дві: по-перше, зниження навантаження на персонал має такі психологічні наслідки, як «Виключення» співробітників із процесів надання послуг; по-друге, скорочення персоналу (як один з інструментів боротьби зі зростанням витрат на одиницю продукціï) погіршує лояльність співробітників роботодавцю. Крім мотиваційних чинників, негативний вплив на якість послуг надає і заміна досвідчених співробітників на більш низькооплачуваних, але таких, що не мають навичок роботи. Формування асортименту, що враховує зміну вимог споживачів до характеристик послуг. Реальне або очікуване зниження платоспроможності споживачів веде до трансформації системи критеріїв, на підставі яких здійснюється вибір конкретного постачальника послуги. Це може вимагати від компаній перегляду портфеля пропонованих послуг і відбитися на інших компонентах маркетинг-міксу (передусім, на цінах, персоналу компанії і фізичному оточенні).

2. У ході ціноутворення основні завдання компаній здорового харчування пов'язані з під- 
триманням належного рівня прибутку. Вирішення цих завдань ускладнене такими чинниками:

- питомі витрати на надання послуг щорічно збільщуються; зростання витрат на одиницю продукції, здебільшого, пов'язано з впливом ефекту масштабу, крім того, витрати можуть зростати внаслідок закону досвіду, в умовах заміни кваліфікованого персоналу на більш дешевий;

- ціна попиту знижується; з одного боку, зменшення реально наявних доходів веде до закономірного зростання чутливості до ціни і перерозподілу попиту на користь дешевих послуг, з іншого боку, споживачі істотно переглядають свої оцінки співвідношень «ціна / якість» для різних послуг, що викликано падінням їх сприйняття цінності;

- зростає ризик цінових війн; прагнення компаній здорового харчування до підтримки необхідного масштабу діяльності, зростання цінової еластичності попиту і властиві послугам складнощі в оцінюванні якості (i, як наслідок, проблеми з диференціацією) підштовхують галузь до цінової конкуренції.

Збутова політика часто отримує яскраво виражену спрямованість на розширення збуту. Загострення конкуренції та боротьба за обсяги збуту змушують об’єкти здорового харчування виходити за межі традиційних для них сегментів (ринків), що можливо тільки при інтенсифікації збуту. Наслідками, як правило, стають конфлікти між різними збутовими каналами і падіння рівня обслуговування в момент продажу (що негативно позначається на сприйнятті загальної якості послуги).

Досліджуючи тенденції закладів здорового харчування, слід звернути увагу на те, що інформація про таку їжу і про самі заклади найчастіше вивчається 3 використанням мережі Інтернет. Особливо молодь дедалі активніше цікавиться темою здоров'я та закладів здорового харчування і шукає потрібну інформацію в Інтернеті. Проаналізувавши статистику Google-трендів у категорії «Їа», дослідники виділили низку головних пошукових тенденцій, пов'язаних зі здоровим способом життя. Одна з них - збільшення кількості запитів про здорове харчування.

Користувачі вивчають інформацію про харчування і заклади здорового харчування в Інтернеті, щоб скласти правильний раціон. Вони добирають його, виходячи зі своїх цілей. За статистикою Google-трендів, з 2005 р. кількість запитів зі словами «яка їжа корисна для» збільшилась в десять разів.

Часто вони доповнюються так: «шкіри», «тонусу», «травлення», «мозку» і «тренувань». Згідно з останнім звітом Food Trends Report про тенден- ції у виборі продуктів харчування, багато людей включають у свій раціон так звані функціональні харчові продукти. Вважається, що вони сприяють зміцненню здоров'я. Відповідно заклади здорового харчування не тільки включають корисні інгредієнти в продукти, але і допомагають підвищити поінформованість покупців про здорове харчування. Фахівці відзначають велику кількість дезінформації. Лідери ринку закладів здорового харчування вважають, що виробникам слід давати інформацію на етикетках і в меню зрозумілішою і використовувати спрощену термінологію.

Інтерес до закладів здорового харчування у світі неухильно зростає протягом останніх років. Компанії громадського харчування змінюють склад продуктів, відкриваються нові спеціалізовані ресторани, загалом компанії змінюють усе - від складу продуктів до підходу до онлайнреклами. Тенденції підтверджують - інтерес до здорової їжі буде продовжувати збільшуватися, тому іншим виробникам варто взяти приклад 3 новаторів. Аналізуючи пошукові запити користувачів, можна точно зрозуміти їх переваги і швидко адаптуватися до них.

Напрямами подальших досліджень стане дослідження тенденцій та перспектив розвитку закладів здорового харчування в Україні.

\section{Література/Reference}

1. Le Velly, R. (2019). Allowing for the projective dimension of agency in analysing alternative food networks. Sociologia Ruralis, 59 (1), 2-22.

2. Petrini, C. (2013). Slow food nation: Why our food should be good, clean, and fair. Rizzoli Publications.

3. Sassatelli, R., \& Davolio, F. (2010). Consumption, pleasure and politics: Slow food and the politicoaesthetic problematization of food. Journal of Consumer Culture, 10 (2), 202-232.

4. Schnepper, R., Richard, A., Wilhelm, F. H. \& Blechert, J. (2019). A combined mindfulness-prolonged chewing intervention reduces body weight, food craving, and emotional eating. Journal of consulting and clinical psychology, 87 (1), 106.

5. Schneider, T., Eli, K., McLennan, A., Dolan, C., Lezaun, J., \& Ulijaszek, S. (2019). Governance by campaign: the co-constitution of food issues, publics and expertise through new information and communication technologies. Information, Communication \& Society, 22 (2), 172-192.

6. Willems, K. (2019). From phenomenology to responsibility. Comments on 'Slow linguistics-a manifesto’. Texto! Textes \& Cultures, 24 (1), 4-10. 


\section{ДЕМОГРАФІЯ, ЕКОНОМІКА ПРАЦІ, СОЦІАЛЬНА ЕКОНОМІКА І ПОЛІТИКА}

\section{ДЕМОГРАФІЧНІ ЧИННИКИ ФОРМУВАННЯ ЛЮДСЬКОГО КАПІТАЛУ УКРАЇНИ}

Анотація. У статті проведено аналіз основних демографічних показників формування людського капіталу. Проаналізовано динаміку та тенденції природного відтворення населення. Визначено основні причини погіршення демографічної ситуації в Україні та їх негативний вплив на формування людського капіталу країни.

Ключові слова: людський капітал, населення, депопуляція, природний рух, смертність, народжуваність.

Summary. The article studies the problems of natural reproduction of the population. The analysis of the main indicators of population reproduction. Analyzed the dynamics and trends of natural reproduction of the population.

Key words: population, depopulation, natural reproduction, natural movement, mortality, fertility.

$$
\text { DOI : 10.33783/1977-4167-2019-46-2-89-96 }
$$

Постановка проблеми. Сучасний етап розвитку в Україні демонструє стрімкі втрати найціннішої складової економічного розвитку та процвітання країни - людського капіталу. Економічна криза, занепад виробництва, безробіття у поєднанні з активізацією міграційних процесів унаслідок анексії Криму та військових дій на Сході, суттєве зниження рівня та якості життя, вкрай негативно відобразилися на його відтворенні. Негативні наслідки зазначених процесів не могли не позначитися на демографічній ситуації країни.

Усвідомлення провідного значення людини в соціально-економічному розвитку країни має стати базовим імперативом стратегічного вектора нашої держави у використанні провідної компоненти продуктивних сил.

Аналіз останніх досліджень і публікацій. Дослідженню сутності, характеристик та умов розвитку трудового потенціалу присвятили свої роботи такі науковці, як: О. I. Амоша, С. М. Ахромкін, Д. М. Богиня, М. П. Бутко, Б. М. Гєнкін, С. С. Гринкевич, О. А. Грішнова, Л. С. Дегтяр, I. О. Джаін, Б. М. Данилишин, М. І. Долішній, С. І. Дорогунцов, П. В. Журавльов, В. І. Захарченко, Ю. М. Забродін, С. М. Злупко, В. М. Ковальов, Р. П. Колосова, О. М. Левченко, Е. М. Лібанова, Л. С. Лісогор, І. С. Маслова, Г. Ю. Міщук, О. Ф. Новікова, В. В. Онікієнко, Т. В. Пепа, I. Л. Петрова, С. I. Пирожков, В. І. Приймак, У. Я. Садова, М. В. Семикіна, М. І. Скаржин- ський, В. П. Удовиченко, Л. Г. Чернюк, Л. М. Черчик, Л. В. Шаульська, О. М. Ярош та ін.

Мета статті - виокремити та оцінити демографічні чинники формування людського капіталу України.

Виклад основного матеріалу дослідження. Традиційно в основі процесу формування людського капіталу покладено спроможність забезпечити демографічне відтворення населення країни. Населення, своєю чергою, виступає природною основою формування людського капіталу, визначає обсяги, структурні характеристики та динаміку його відтворення.

Демографічна ситуація виступає індикатором соціально-економічного розвитку країни та відображенням особистого стану населення країни. Аналіз динаміки чисельності населення України за роки незалежності характеризується сталою тенденцією зниження сукупності населення. У 2018 р. чисельність населення України становила 42, 4 тис. осіб і порівняно з даними перепису населення 1991 р. зменшилась на 9558,0 тис. осіб, або на 18,4 \%. Але слід зазначити, що дані за 2015-2018 рр. подаються без урахування «тимчасово окупованої території Автономної Республіки Крим і м. Севастополя», а також неконтрольованих Києвом територій на Сході країни у Донецькій та Луганській областях.

Незважаючи на те, що з 1991 р. кількість померлих в Україні вперше перевищила кількість

(С) Л. І. Антошкіна, О. В. Скворцова, 2019

Бібліографія ДСТУ 8302:2015:

Антошкіна Л. І., Скворцова О. В. Демографічні чинники формування людського капіталу України. Вісник Бердянського університету менеджменту і бізнесу. 2019. № 2 (46). С. 89-96.

References (APA):

Antoshkina, L. I., Skvortsova, O. V. (2019). Demohrafichni chynnyky formuvannia liudskoho kapitalu Ukrainy [Demographic factors of human capital formation in Ukraine]. Visnyk Berdianskoho universytetu menedzhmentu i biznesu, 2 (46), 89-96 (in Ukr.). 
народжених, до 1993 р. спостерігається загальний приріст населення. За ці роки відбулася певна «компенсація» за рахунок тих, хто повертався до свого українського коріння після розпаду СРСР. I у 1993 р. населення України досягло свого максимуму - понад 52 млн осіб. Але після вичерпання «етнічного підгрунтя» міграція припинилася, i з 1994 р. в Україні відбувається абсолютне скорочення чисельності населення [6] (рис. 1).
Причому суттєво відрізняється процес скорочення сільського та міського населення; так міських жителів скоротилося на 16,3 \% (5,7 млн осіб), а сільських на 22,8 \% (3,8 млн осіб). Скорочення сільського населення відбувається значно більшими темпами ніж міського. Слід зазначити, що за період від 1994 по 2018 рр. з карти України зникло 485 сіл. А рівень урбанізації у 1993 р. становив 67,9\%, а у 2018 р. збільшився до 69,3\%.

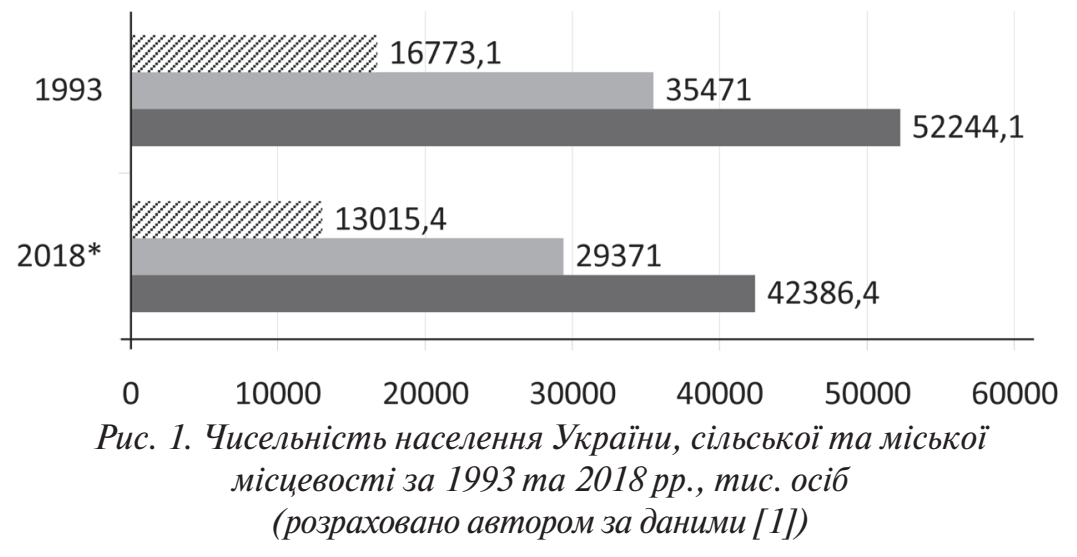

Дана тенденція зумовлена низкою економічних, соціальних та демографічних факторів.

Видання Quartz, проаналізувавши дані ООН по всіх країнах, зазначає, що Україна входить до п’ятірки лідерів за темпами скорочення населення $(-18 \%)$, поступаючись лише Болгарії $(-23 \%)$, Латвії (-22 \%) та Молдові (-19\%). На п’ятому місці - Хорватія (-17\%) [2].

Україна зазнала суттєвих демографічних втрат, що своєю чергою призводить до скорочення при- родної бази відтворення людського капіталу країни. 31991 р. сформувалась стала тенденція негативного сальдо природного приросту населення. У результаті перевищення кількості померлих над кількістю народжених, населення країни скоротилося на 6,7 млн осіб, тобто на $13 \%$. Депопуляція зумовила зменшення мешканців сільської місцевості на 3,2 млн осіб, або на 19,2 \%, а міського населення на 3,5 млн осіб, на $10 \%$ (рис. 2). Очевидно, що на сьогодні особливо загострена проблема при-

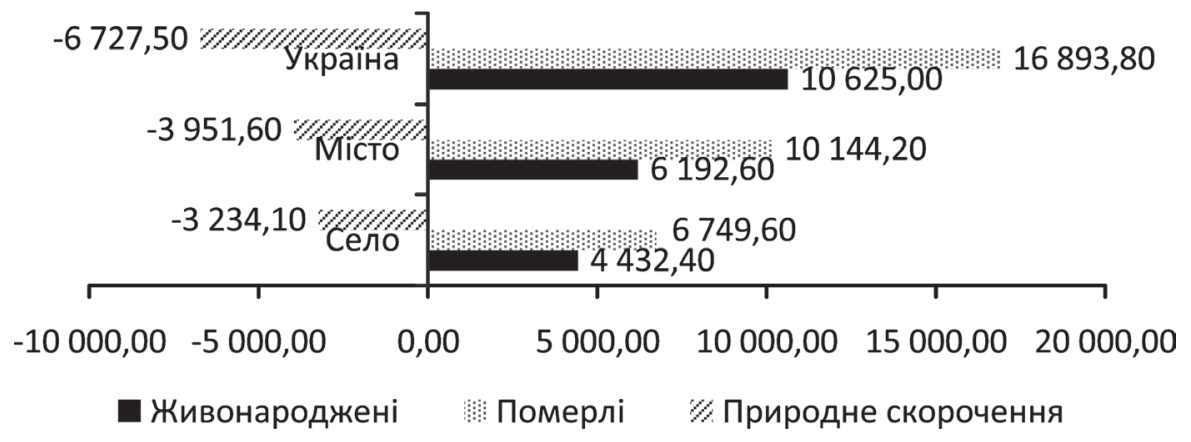

Рис. 2. Природний рух населення України за 1991-2017 рр., тис. осіб (розраховано автором за даними [1])

родного скорочення населення, яке відіграє провідну роль у процесі загального зменшення його чисельності. Звичайно, наявність такого рівня депопуляції закономірно дозволяє характеризувати демографічну ситуацію в Україні як кризову, що своєю чергою стає на заваді процесу відтворення людського капіталу країни.

Рис. 3 наочно демонструє, що за весь досліджуваний період в Україні показники природного відтворення є від'ємними, що вказує на те, що кожний рік смертність перевищує народжуваність та чисельність населення скорочується. Смертність у середньому по Україні, станом на 2017 р. майже в 1,6 рази перевищує народжуваність, а у сільській місцевості даний показник сягає 1,8 рази.

На рис. 4 видно, що у 1995 р. коефіцієнт природного збільшення (скорочення) населення різко опустився до 5,8 \% порівняно з 1991 , коли він склав лише 0,8\%. У 1995 р. населення

\footnotetext{
* Без тимчасово окупованої території Автономної Республіки Крим, м. Севастополя та частини тимчасово окупованих територій у Донецькій та Луганській областях.
} 


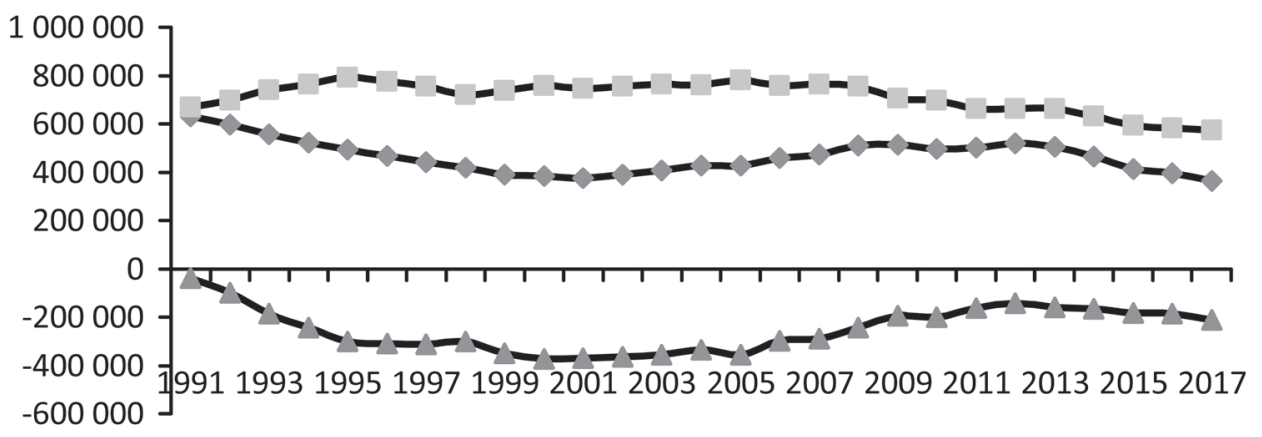

$$
\text { - Живонароджені - - Померлі - -Природний приріст (скорочення) }
$$

Рис. 3. Динаміка чисельності живонароджених, померлих і природного скорочення населення України за 1991-2017 рр., тис. осіб (складено автором за даними [1])

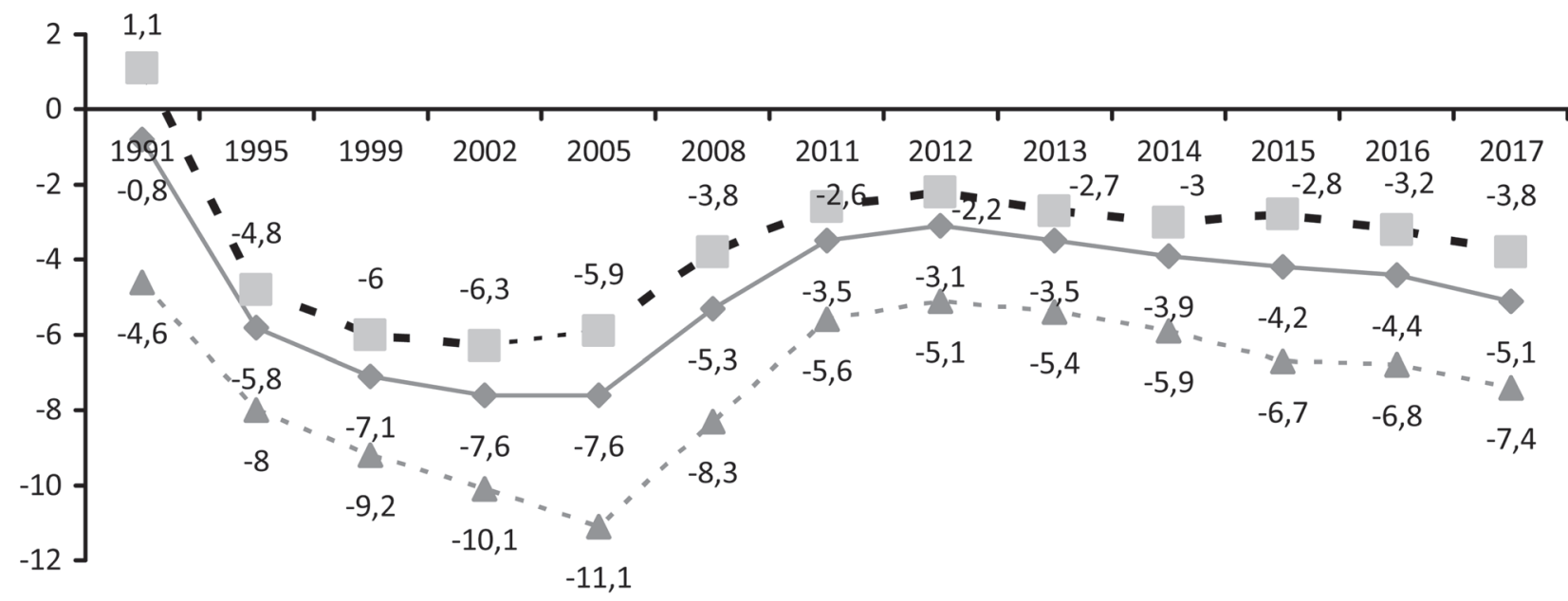

— Населення України - - - Міське населення - - - - Сільське населення

Рис. 4. Динаміка природного скорочення населення України, міської та сільської місцевості за вибраними роками за період від 1991 до 2017 рр., \% (складено автором за даними [1])

скоротилося на 299,7 тис. осіб, що значно перевищує чисельність скорочення 1991 (39,1 тис. осіб), а смертність перевищувала народжуваність у 1,6 рази. Особливо інтенсивними темпами депопуляція проходить від 1999 (-7,1 \%) до 2005 р. $(-7,6 \%)$. Найбільше населення країни скоротилося у 2000 р. на 373,0 тис. осіб, коли чисельність померлих була вдвічі більше, ніж народжених. На 364,2 тис. осіб скоротилося населення України за 2002 р., а коефіцієнт природного скорочення становив 7,6\%.

Наступні роки коефіцієнт природного росту (скорочення) демонструє динаміку зниження темпів зменшення населення і у 2008 р. показник природного скорочення вже дорівнює 5,3\% (243,9 тис. осіб). Найкращим показником відзначається 2012 р., коефіцієнт скорочення склав лише 3,1 \%, а кількість населення зменшилася на 142,4 тис. осіб. Наступні роки тенденція до збільшення показника скорочення населення відновилася, і у 2015 р. коефіцієнт природного скорочення становив 4,2 \%, а у 2017 p. $-5,1 \%$.
Суттєво відрізняється динаміка показника природного скорочення сільської місцевості населення, вона помітно перевищує темпи скорочення мешканців міст. У 1991 р., коли коефіцієнт природного руху міського населення ще був додатним, а сільської місцевості вже був від'ємним і становив 4,6 \%, а наступні роки значно перевищував коефіцієнт природного руху міського населення.

Таким чином, реальна картина демографічних процесів свідчить, що демографічна ситуація набула характеру гострої демографічної кризи: відбуваються несприятливі зміни в чисельності населення країни внаслідок депопуляції.

Основною складовою демографічної кризи є значне зниження народжуваності, про що свідчать динаміка кількості народжень та показники інтенсивності цього процесу (рис. 5). Так, у 2018 р. і порівняно із 1991 р. кількість народжень в Україні скоротилася майже вдвічі, а точніше на 47 \%. Стала тенденція зниження показників народжуваності сформувалася починаючи з 1991 р. Так у 1991 р. народилося 630,8 тис. немовлят, а у 


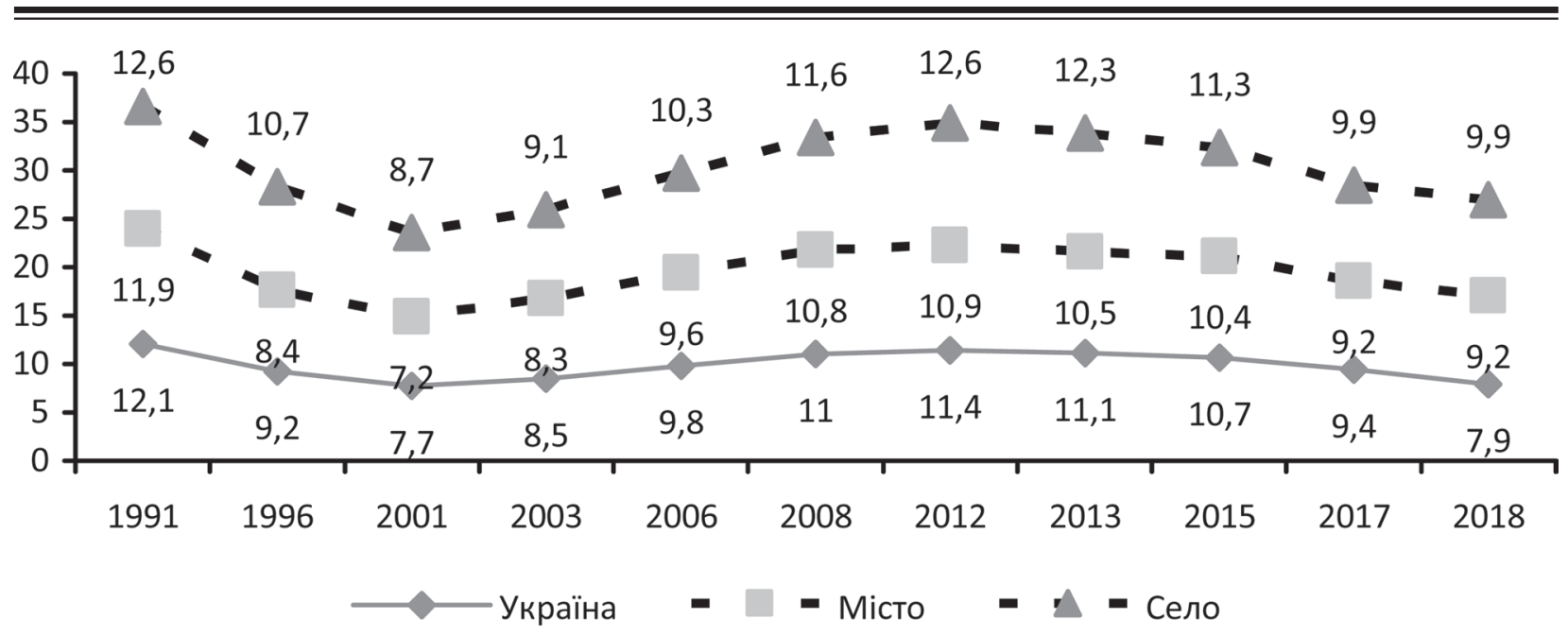

Рис. 5. Коефіцієнт народжуваності в Україні, міської та сільської місиевості за вибраними роками за період з 1991 по 2018 рр., \% (складено автором за даними [1])

1996 - 467,2 тис., тобто динаміка за даний період вказує на зниження народжуваності на 25,9\%. Коефіцієнт народжуваності, який у 1991 р. був 12,1\% у 1996 - опустився до 9,8 \%. Найгірші показники народжуваності припали на 1999-2002 pр. - тоді в Україні народжувалося менше 400 тис. немовлят. Найменший показник народжених на кожну тисячу осіб - лише 7,7 \%- був зафіксований у 2001 р. Так, у 2001 р. народилося лише 376,5 тис. дітей, що на 40,3\% менше ніж у 1991 році.

Починаючи з 2003 р., спостерігається деяке підвищення народжуваності через відносну стабілізацію економічної ситуації й підвищення життєвого рівня, певну активізацію соціальної політики (виплати при народженні дітей), поступову адаптацію населення до нових соціальноекономічних умов. Так, за період від 2003 до 2012 pp. зафіксовано збільшення чисельності народжених, яке стало наслідком компенсації відкладених у кризові роки народжень, та частково зумовлено вступом у дітородний вік численніших контингентів жінок 1983-1988 року народження. У 2003 р. було зареєстровано 408,6 тис. немовлят, а у 2012 - 520,7 тис., це вказує на те, що за даний період народжуваність зросла на 27,4 \%. На позитивну динаміку народжених починаючи з 2006 р. (8,9\% порівняно з 2005 р. - 8,0 \%) вплинуло також введення суттєвої одноразової допомоги при народженні дитини. Одноразову допомогу при народженні дитини було введено 3 1 квітня 2005 р. До кінця 2007 р. вона становила 8,5 тис. грн [7]. Помітний стрибок народжуваності стався в 2008 р, коли загальний коефіцієнт народжуваності становив $11,0 \%$. Він торкнувся народження дітей усіх черговостей, крім перших. Цей сплеск пов'язаний з новими заходами демографічної політики, введеними в дію в 2007 р. А саме, збільшенням грошової допомоги матерям, які народили двох і більше дітей. Як відомо, у березні 2008 р. Уряд підвищив виплату при на- родженні першої дитини до 12,24 тисяч гривень, другої - до 25 тис. грн, третьої й наступних - до 50 тис. грн. У результаті наступні роки показники народжуваності трималися на високому рівні, наприклад, у 2011 р. коефіцієнт народжуваності був $11,0 \%$, а 2012 р. визначився найкращим показником - $11,4 \%$.

Починаючи з 2013 р. відновлюється тенденція зниження народжуваності. Так, у 2013 коефіцієнт народжуваності становив 11,1\%, у 2017 р. він опустився до 9,4 \%. Найбільш різке падіння було зафіксоване в 2018 р., коли коефіцієнт народжуваності знизився до 7,9 \%. Якщо в 2013 р. в країні налічувалося 503,7 тис. новонароджених, то в 2018 р. вже 335,9 тис., народжуваність скоротилася на 33,3 \%. Навіть у селах, де народжуваність традиційно вища ніж у містах, коефіцієнт народжуваності опустився до $9,9 \%$.

Але останніми роками склалася тенденція більш інтенсивного скорочення народжуваності на селі. Так, у містах України у 2017 р. народилося 237,9 тис. немовлят, це на 10,6 \% менше ніж у 2015 р., а у селах за цей самий період народжуваність скоротилася 13,5\%.

Зміни у рівні народжуваності, що відбуваються в Україні, супроводжуються значною трансформацією вікової моделі репродуктивної поведінки. Поступовий перехід на нову модель народжуваності, де головним є «постаріння» материнства, зумовив відповідні зміни в народжуваності в різних вікових групах жінок дітородного віку (рис. 6). Так, у 1991 р. основний внесок у народжуваність припадав на молодих жінок віком від 20 до 24 років (41,5 \%), а на другому місці була вікова категорія жінок віком від 25 до 29 років, їхній внесок становив 23,8 \%. До 2017 р. у ситуація кардинально змінюється і основний відсоток народжуваності забезпечують більш зрілі жінки; так у жінок у віковій категорії від 25 до 29 років народилося 32,2 \% від усіх новонароджених немовлят. 


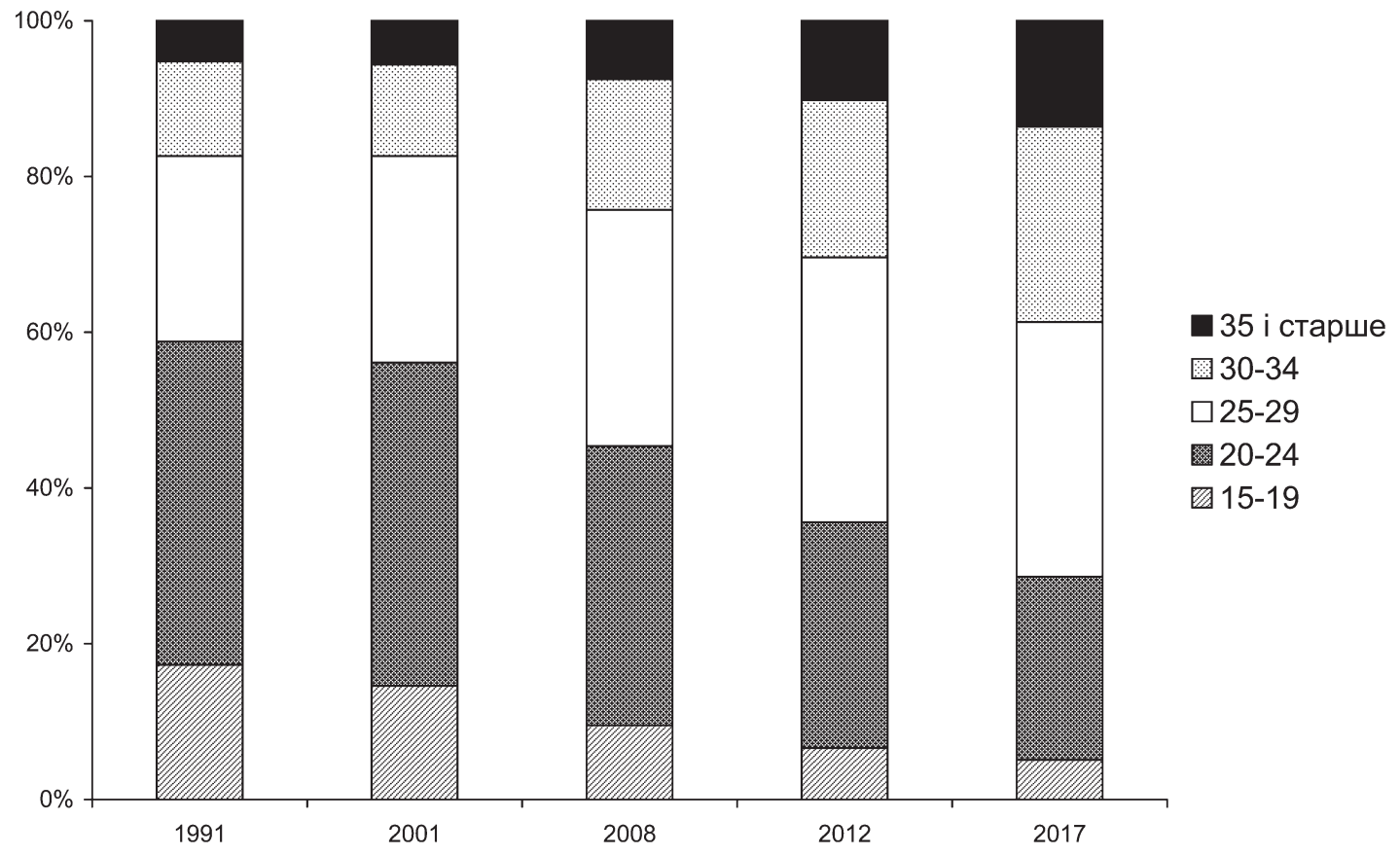

Рис. 6. Повікові коефіцієнти народжуваності молодих жінок y 1991, 2001, 2008, 2012 ma 2017 pp., \%

(розраховано автором за даними [1]

У 2017 р. чисельність немовлят, народжених у віковій категорії 30-34 роки, склала $25,1 \%$, коли у 1991 р. вона була лише 12,2 \%. Зміни відбулися і у віковій категорії 35 і старше; так на початку періоду жінки в цьому віці забезпечували лише 5,2 \%, а на сьогодні пізнє материнство стає закономірністю і становить 13,6 \%. Але натомість народження дітей в юному віці стає рідкісним явищем, внесок молодих дівчат у віці від 15 до 19 років склав лише 5,1\%, тоді як у 1991 він становив 17,3\%.

Така тенденція є наслідком економічних та соціальних проблем. Жінки насамперед хочуть самореалізуватися, стати економічно самостійними, створити основу для подальшого життя, а потім вже заводити дитину. Тому материнство відкладається на пізніші строки, що залишає менше можливості для народження другої дитини. Іншою проблемою виступає фінансова нестабільність сім’ї. Виховання двох і більше дітей доступно не кожній родині, яка обмежується однією дитиною. Про це свідчить показник сумарного коефіцієнта народжуваності, або його називають коефіцієнт фертильності. Це найточніший вимір рівня народжуваності, він характеризує середню кількість народжень у однієї жінки за все їі життя. За умов низької смертності для простого заміщення поколінь сумарний коефіцієнт народжуваності має бути не нижчим за 2,15. В Україні у 2017 р. він становить лише 1,37, очевидно, що цього недостатньо для відтворення населення. Слід зазначити, що у 2013 р. по Україні даний показник був 1,51. У містах жінки мали у середньому 1,37 дитину, натомість як у сільській місцевості на одну жінку припадало 1,83 дитини. У 2017 сумарний коефіцієнт народжуваності у місті знизився до 1,28 , а на селі відбулося більш значне скорочення даного показника, отже, тепер навіть у сільській місцевості одна жінка має лише 1,52 дитину [1].

Оцінюючи певні позитивні зрушення в царині народжуваності населення України протягом 2003-2012 рр., можна дійти висновку, що незначне зростання кількості народжених не вказує на кардинальний перелом тенденції зниження народжуваності, оскільки не зникли чинники, що призвели до падіння рівня дітородної активності. До них слід віднести падіння рівня якості життя населення, безробіття, низьку оплату праці, низький рівень та високу вартість послуг сфери охорони здоров’я, відсутність соціального захисту. До негативних чинників, які призвели до зниження народжуваності, долучилися фактори, пов'язані зі збройним конфліктом на Сході України, які стали причиною погіршення даного показника за останні роки. Названі чинники комплексно активно впливають на подальше зниження рівня народжуваності.

Різке падіння рівня та якості життя у трансформаційний період створили підгрунтя для зростання захворюваності і смертності та відчутного зниження середньої тривалості життя, а погіршення доступності медичного обслуговування стало причиною ще більшого нехтування здоров'ям унаслідок соціально-психологічної дезадаптації в умовах тривалої соціально-економічної кризи [3]. Динаміка показника смертності особливо збільшилися у першій половині $90-\mathrm{x}$ років з розгортанням в Україні соціально-економічної кризи, яка набула тотального характеру (рис. 7). У 1995 р. 


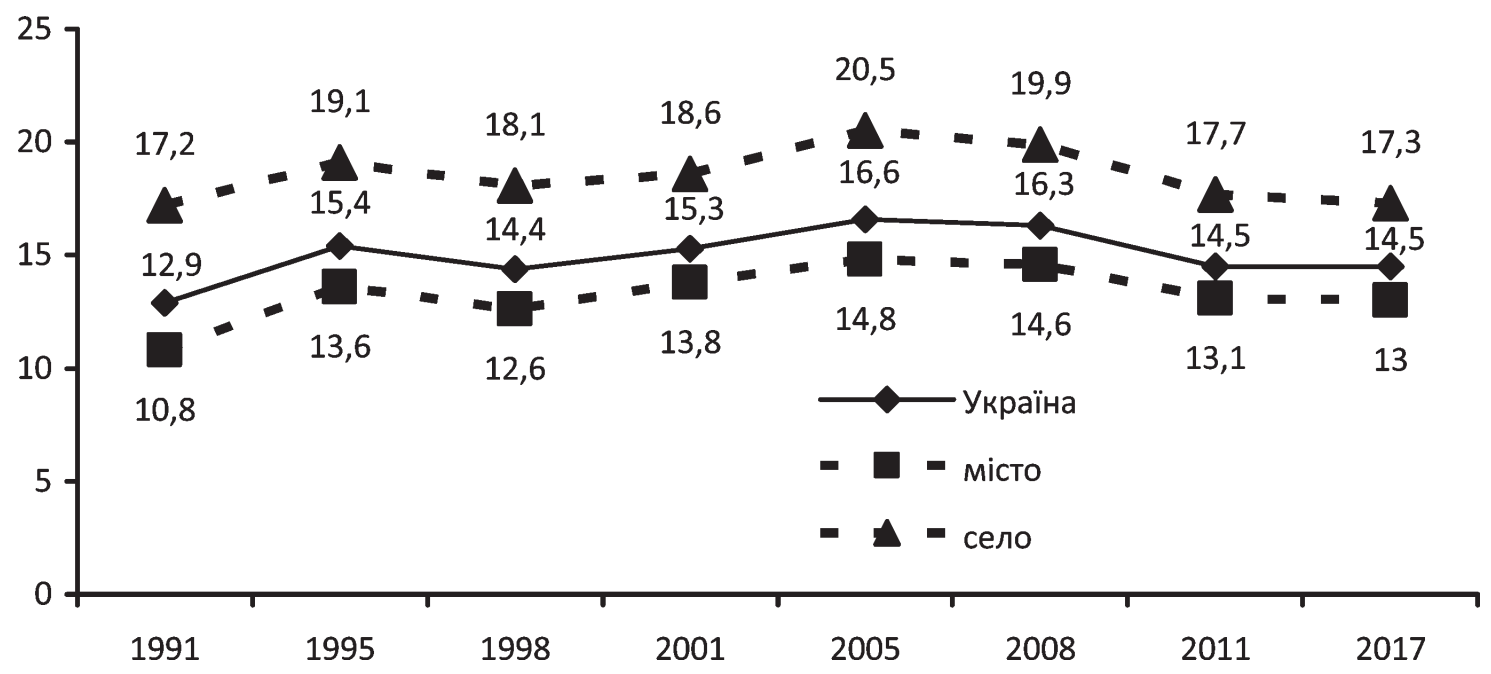

Рис. 7. Коефіцієнт смертності України, міської та сільської місцевості, за вибраними роками за період від 1991 до 2017 рр., \% (складено автором за даними [1])

кількість померлих досягла 792,6 тис. осіб, тобто збільшилася на 161,8 тис. осіб, або на 20,4 \%, порівняно з 1991 р., а коефіцієнт смертності досяг $15,4 \%$. Після максимального загострення кризи смертність в Україні почала знижуватись. У 1998 р. вона зменшилася на 9,2 \%, коефіцієнт смертності опустився до 14,5\%. Наступними роками знову відновлюється тенденція збільшення смертності і у 2005 р., коли в Україні померло 782 тис. осіб і чисельність померлих збільшилася на $9 \%$, коефіцієнт смертності піднявся до $16,6 \%$, а серед мешканців сіл він досяг аж 20,5\%. Починаючи з 2011 р., показник смертності дещо зменшився до $14,5 \%$, але все одно не досяг рівня показника 1991 р., коли рівень смертності дорівнював 12,9\%. Наступними роками показник смертності коливався повільними темпами, і у 2017 зупинився на позначці 14,5 \%. Крім того, слід зазначити, що у рейтингу країн світу за рівнем смертності у 2018 р. Україна посіла шосте місце з коефіцієнтом смертності 14,3\%, поступившись лише Латвіі (14,5\%), Болгарії (14,5\%), Лесото (15,1\%) та Південному Судану (19,3\%) [5].

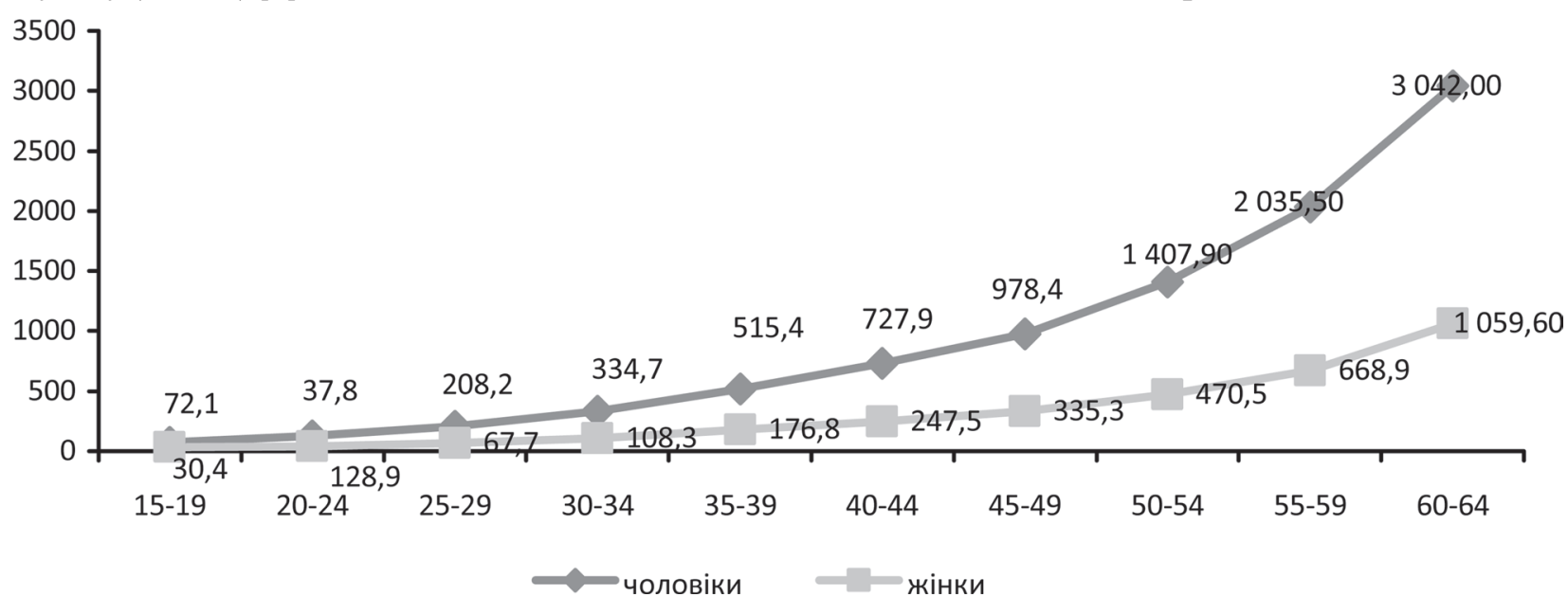

Рис. 8. Повікові коефіцієнти смертності чоловіків і жінок за 2017 р. (складено автором за даними [1])
Особливо помітна відмінність рівня смертності мешканців сіл, де коефіцієнт смертності значно перевищує смертність у містах України. Так, у 2011 р. рівень смертності міського населення був 13,1 \%, а сільського 17,7 \%., у 2017 р. показдорівнював 17,3\%, а міської $13 \%$.

Найгострішою демографічною проблемою сучасної України є висока передчасна смертність населення молодого віку, особливо чоловіків (рис. 8). Рівень смертності жінок нижчий ніж чоловіків на всьому віковому профілі. Показники смертності чоловіків в Україні в сучасний період у 2-3 рази вищі, ніж у жінок.

У віковій категорії 15-19 років смертність чоловіків була у 2,4 рази більша ніж жінок, серед осіб 20-24 роки індекс надсмертності чоловіків становив 3,4, у віці 30-34 чоловіча смертність перевищує жіночу в 3,1 рази. У вікових категоріях 35-39, 40-44 та 45-49 років надсмертність чоловіків становила 2,9. А у віці 50-54 та 55-59 надсмертність чоловіків була втричі вища ніж жіноча. Слід зазначити, що смертність чоловіків на селі ник смертності мешканців сільської місцевості 
вища ніж у містах, так у 2017 р. індекс надсмертності чоловіків сільської місцевості коливався у межах 1,3-1,4 у вікових категоріях чоловіків від 20 до 59 років.

Найпоширенішою причиною смерті залишаються хвороби системи кровообігу, які у 2017 р. стали причиною смерті 67,1 \% населення країни, $13,6 \%$ смертей були спричинені онкологічними захворюваннями. Висока надсмертність у молодому віці зумовлена тим, що значне місце відіграє екзогенна патологія (табл. 1). Більша частина не- природної смерті людей у молодому віці від 20 до 39 років викликана транспортними нещасними випадками та самогубством. Хвороби системи кровообігу часто стають причиною передчасної смерті, від яких у 2017 р. померло 4283 людей у віці від 20 до 39 років. Приблизно кожна тринадцята смерть детермінована СНІДом, який став причиною смерті 1767 осіб у молодому віці.

Основною проблемою для України виступає стала тенденція надвисоких показників смертності населення, особливо серед молоді, ув якій

Таблиия 1

Смертність за причинами смерті і вибраними віковими групами в Україні, 2017 р., \% (розраховано автором за даними [1])

\begin{tabular}{|l|c|c|c|c|c|}
\hline \multicolumn{1}{|c|}{ Захворювання } & $20-24$ & $25-29$ & $30-34$ & $35-39$ & $20-39$ \\
\hline Туберкульоз органів дихання & 0,8 & 1,7 & 2,4 & 2,6 & 2,2 \\
\hline $\begin{array}{l}\text { Хвороба, спричинена вірусом імунодефіциту } \\
\text { людини (ВІЛ) }\end{array}$ & 1,3 & 6,0 & 7,9 & 8,8 & 7,4 \\
\hline Новоутворення & 8,5 & 7,1 & 7,6 & 10,4 & 8,8 \\
\hline Хвороби нервової системи & 3,7 & 3,6 & 3,0 & 2,9 & 3,1 \\
\hline Хвороби системи кровообігу & 8,5 & 14,3 & 17,9 & 21,2 & 18,1 \\
\hline Хвороби органів дихання & 1,9 & 3,7 & 4,9 & 4,9 & 4,4 \\
\hline Хвороби органів травлення & 4,0 & 7,7 & 11,4 & 13,4 & 11,0 \\
\hline Зовнішні причини смерті & 63,7 & 47,5 & 35,4 & 26,8 & 35,9 \\
\hline
\end{tabular}

високий рівень смертності від ендогенних причин поєднується 3 не менш високим рівнем смертності від екзогенних патологій, при цьому внесок екзогенних причин доволі істотний. На сьогодні для України характерний високий рівень смертності від так званих соціально детермінованих захворювань, жертвами яких є, перш за все, особи молодого і середнього віку [4].

Висновки. Демографічний чинник покладено в основі забезпечення сталого соціально-економічного розвитку держави. Проблеми оптимального демографічного розвитку необхідно розглядати не лише як пріоритетні інтереси держави, а i як результати реалізації іiї соціально-економічної політики. Проведений аналіз сучасної демографічної ситуаціï, а також іiі динаміки за роки незалежності свідчить про наявність в Україні глибокої демографічної кризи інертного характеру. За таких умов, особливого значення набуває демографічна компонента формування людського капіталу країни. Втрата природного підгрунтя відтворення населення призведе до серйозних соціально-економічних проблем. Для сучасної демографічної ситуації в Україні характерно перевищення смертності над народжуваністю і, відповідно відсутність природного приросту.

Основними причинами передчасної надлишкової смертності населення стали руйнації старої системи охорони здоров'я населення та неможливості користуватися послугами медичних закладів ринкового типу через неплатоспроможність населення; різкому зниженні життєвого рівня населення, незбалансованості харчування та поширення шкідливих звичок; а також збільшенні стресових ситуацій через соціальну невизначеність статусу й належного соціального захисту щодо оплати праці, безробіття, пенсійного забезпечення та ін.

Основна причина зниження народжуваності до рівня, який не забезпечує збереження чисельності населення, в сучасних умовах полягає в тому, що задоволення потреби в дітях, материнстві та батьківстві конкурує з низкою інших потреб, тим елементарніших, чим нижчий рівень життя. Виявлені причини низької народжуваності вказують на те, що українське суспільство зможе подолати демографічні проблеми лише, коли його населення матиме відповідний рівень якості життя і отримає відчуття соціально-економічної безпеки для реалізації нормальної демовідтворювальної поведінки.

У цьому контексті вкрай необхідним є створення такого суспільного середовища, інституційне оформлення якого забезпечить надійну економічну базу для відтворення населення і створить умови для вибору поведінки, орієнтованої на зміцнення здоров'я і працездатності. Підгрунтям для досягнення конструктивних змін має бути покладено посилення демографічної ефективності всіх напрямів соціально-економічної політики.

\section{Література}

1. Державна служба статистики України. Інститут демографії та соціальних досліджень імені 
М. В. Птухи Національної Академії Наук України URL : http://database.ukrcensus.gov.ua.

2. ООН: Украина входит в топ-5 стран мира по темпам сокращения населения. URL : https:// gordonua.com/news/society/oon-ukraina-vhodit-vtop-5-stran-mira-po-tempam-sokrashcheniya-naseleniya-228556.html.

3. Смертність населення України у трудоактивному віці : монографія / відпов. ред. Е. М. Лібанова. К. : Ін-т демографії та соціальних досліджень НАН України, 2007. 211 с.

4. Смертность населения Украины в трудоактивном возрасте (25-64 года). URL : http://www. demoscope.ru/weekly/2009/0403/analit01.php.

5. Список стран по уровню смертности. URL : https://nonews.co/directory/lists/countries/death.

6. Українська демографія: що змінилося за 25 років. URL : https://www.bbc.com/ukrainian/ society/2016/08/160801_ukraine_demography_az.

7. У 2008 році збільшилася допомога при народженні дитини. URL : https://www.unian.ua/ politics/87280-u-2008-rotsi-zbilshilasya-dopomogapri-narodjenni-ditini.html.

\section{Reference}

1. State Statistics Service of Ukraine. MV Birds Institute of Demography and Social Research of the National Academy of Sciences of Ukraine. Retrieved from http://database.ukrcensus.gov.ua.
2. OON: Ukrayna vkhodyt $v$ top-5 stran myra po tempam sokrashchenyia naselenyia [UN: Ukraine is in the top 5 countries in terms of population decline]. Retrieved from https://gordonua.com/news/society/ oon-ukraina-vhodit-v-top-5-stran-mira-po-tempam -sokrashcheniya-naseleniya-228556.html.

3. Libanova E. M. (ed.) (2007). Smertnist naselennia Ukrainy u trudoaktyvnomu vitsi [Mortality of the population of Ukraine in working age]. Kyiv, Instytut demohrafii ta sotsialnykh doslidzhen NAN Ukrainy, 2007. $211 \mathrm{c}$.

4. Smertnost naselenyia Ukraynu v trudoaktyvnom vozraste (25-64 hoda) [Mortality of the population of Ukraine in working age (25-64 years)]. Retrieved from http://www.demoscope.ru/weekly/2009/0403/ analit01.php.

5. Spysok stran po urovniu smertnosty [List of countries by mortality rate]. Retrieved from https:// nonews.co/directory/lists/countries/death.

6. Ukrainska demohrafiia: shcho zminylosia za 25 rokiv [Ukrainian Demography: What Has Changed in 25 Years]. Retrieved from https://www.bbc.com/ ukrainian/society/2016/08/160801_ukraine_demography_az.

7. U 2008 rotsi zbilshylasia dopomoha pry narodzhenni dytyny [In 2008, childbirth assistance increased]. Retrieved from https://www.unian.ua/ politics/87280-u-2008-rotsi-zbilshilasya-dopomogapri-narodjenni-ditini.html. 


\title{
ДЕРЖАВНІ ОСВІТНІ ВИДАТКИ ТА ДОСТУПНІСТЬ ОСВІТИ ДЛЯ УКРАЇНСЬКИХ ДОМОГОСПОДАРСТВ
}

\begin{abstract}
Анотація. Стаття містить апробацію аналітичних прийомів, призначених для оцінювання внеску бюджетних секторів соціальних галузей економіки в динаміку добробуту домогосподарств. Оцінено внесок бюджетного сектору освіти у добробут домогосподарств опосередковано: через динаміку попиту на комериійний сектор освіти. Вважаючи послуги комерційного і бюджетного секторів освіти щільно пов'язаними в процесі задоволення потреб домогосподарств, на прикладі України було досліджено відносини взаємозамінності й взаємодоповнюваності між благами, що постачають бюджетний $і$ комерційний сектори освіти. Для цього було досліджено функціональний зв'язок між масштабами ресурсного забезпечення бюджетного сектору галузі $i$ попитом на блага (товари і послуги), що постачає ї̈ комерційний сектор. Результати моделювання емпірично підтвердили здатність обмежувати темпи зростання цін на послуги освітньої галузі, розширення ресурсного забезпечення комерційного сектору і не виявили такої здатності у розширенні ресурсного забезпечення бюджетного сектору освіти. Виявлені ознаки того, що розширення ресурсного забезпечення бюджетного сектору освіти супроводжується зростанням тиску на ресурсні можллиості комериійного сектору: спостерігається ефект витіснення, відомий у макроекономіці стосовно держсавних і приватних інвестицій.
\end{abstract}

Ключові слова: соціальні галузі, освіта, бюджетні витрати, доступність благ, комериійний сектор, бюджетний сектор, масштаби споживання.

Summary. The article contains a test of analytical techniques intended to assess the contribution of budgetary sectors of social sectors of the economy to the dynamics of household welfare. The article estimates the contribution of the budgetary education sector to the welfare of households indirectly: due to the dynamics of demand for the commercial education sector. Considering the services of the commercial and budgetary education sectors are tightly coupled in the process of meeting the needs of households, Ukraine has explored the interchangeability and complementarity relationships between the goods supplying the budgetary and commercial education sectors. To this end, a functional relationship was explored between the size of the sector's budgetary resources and the demand for goods (goods and services) supplied by its commercial sector. The simulation results have empirically confirmed the ability to limit the pace of price increases for educational services, expand the resource provision of the commercial sector, and have not shown such ability in expanding the resource provision of the budgetary education sector. Signs have been identified that the expansion of resource provision to the budgetary education sector is accompanied by an increase in pressure on the resources of the commercial sector: there is a crowding-out effect known in the macroeconomics regarding public and private investment.

Keywords: social sectors, education, budget expenditures, goods availability, commercial sector, budget sector, consumption.

$$
\text { DOI : 10.33783/1977-4167-2019-46-2-97-104 }
$$

Постановка проблеми. У сучасній Україні фінансована державою і безоплатна для домогосподарств освіта (загальна середня і професійно-технічна освіта, вища освіта за державним замовленням) залишається вагомим чинником добробуту широких верств населення. Водночас активно розвивається комерційна освіта, що іноді конкурує з бюджетним сектором галузі за ресурси, іноді використовує їх спільно. Наприклад, державні українські ВНЗ надають послуги як за державним замовленням (безоплатно для студентів, одержуючи бюджетне фінансуван- ня), так і на комерційній основі. Функціонування масштабного неофіційного ринку освітніх послуг (репетиторство, приховані «доброчинні» платежі в навчальних закладах) ми залишаємо за межами нашого дослідження і фокусуємось на складній взаємодії бюджетних і комерційних механізмів фінансування, яка, на нашу думку, пояснює значну частину можливостей і обмежень, з якими стикається украінська освіта.

Методологія цієї статті грунтується на тому, що кінцеві результати функціонування галузей

( Д. В. Верба, І. С. Верховод, 2019

Бібліографія ДСТУ 8302:2015:

Верба Д. В., Верховод І. С. Державні освітні видатки та доступність освіти для українських домогосподарств. Вісник Бердянського університету менеджменту і бізнесу. 2019. № 2 (46). С. 97-104.

References (APA):

Verba, D. V., Verkhovod, I. S. (2019). Derzhavni osvitni vydatky ta dostupnist osvity dlia ukrainskykh domohospodarstv [Budget expenditures and education availability for ukrainian households]. Visnyk Berdianskoho universytetu menedzhmentu i biznesu, 2 (46), 97-104 (in Ukr.). 
(і зокрема бюджетних їх секторів) проявляються через характеристики споживання домогосподарств (динаміка фізичних обсягів споживання, відносні ціни благ та їх доступність). Відповідно, дослідивши зв'язок між змінами в структурі ресурсного забезпечення певної галузі (в цьому випадку - зміни пропорцій бюджетного і комерційного фінансування освіти - як факторними параметрами) і змінами доступності благ, що постачає освіта для домогосподарств (як залежним параметром), ми отримаємо змістовну оцінку можливостей поліпшення добробуту населення в процесі реформування механізмів ресурсного забезпечення галузі.

Для цього в статті вирішується низка завдань. Зокрема, ми намагаємось знайти відповіді на такі питання, як: 1) Чи існує позитивний зв'язок між приростом реальної вартості ресурсів, що отримують постачальники комерційного і бюджетного секторів галузі, й фізичними обсягами споживання створюваних ними благ? 2) Чи супроводжується розширення масштабів бюджетного фінансування галузі скороченням споживання благ, створюваних комерційним сектором? Зниженням цін, за якими вони надаються через ринкові механізми? Та навпаки, чи дозволяє зростання приватних видатків на блага освіти скорочувати видатки бюджету, не погіршуючи забезпеченість (хоча б середній іï рівень) домогосподарств відповідними благами?

Об’єктом цього дослідження є провідна галузь соціальної сфери України - освіта. Предметом - зв'язок між масштабами ресурсів, одержуваним комерційним і бюджетним секторами галузі й масштабами споживання благ, що вони надають домогосподарствам.

Аналіз останніх досліджень і публікацій. Найближчі до нашого дослідження як за об'єктом, так і за проблематикою, публікації присвячені оцінюванню суспільного ефекту від державної присутності в галузях соціальної сфери (в першу чергу - в охороні здоров'я та освіті), що об'єднані спільною ідеологією «more value for monies» [1-3].

У цій роботі грунтуємось на трьох базових принципах таких досліджень, що дозволять ідентифікувати розміри тих бюджетних видатків, які зумовлені виробництвом певних категорій благ, відомості про масштаби споживання яких містить українська національна статистика.

По-перше, для вирішення проблеми ідентифікації видатків, пов'язаних саме зі створенням певної групи благ - прийоми поєднання галузевої, програмної та функціональної класифікації бюджетних видатків, що поширено застосовуються в сучасних дослідженнях ефективності державної економічної діяльності.

По-друге, для формулювання системи показників результативності державної економічної діяльності в галузі, виділення груп інструментальних (наприклад, чисельність лікарів на тисячу населення - для оцінки результативності державної діяльності в галузі охорони здоров'я, зарплата вчителів та ії відношення до середньої в економіці - для оцінки результатів державних видатків на освіту) і кінцевих (самоцінних) показників (середня очікувана тривалість життя та рівень смертності від захворювань певної нозології - для оцінки ефекту в галузі охорони здоров’я, та оцінки рівня знань випускників навчальних закладів - для визначення ефекту державних освітніх програм, як наприклад, в працях [2; 4].

Для трактування застосовуваних нами кількісних показників важливо, що вони безпосередньо пов'язані з добробутом споживачів освітніх послуг: фізичні обсяги споживання благ, створюваних освітою; їх відносні ціни; доступність (як співвідношення динаміки доходів і цін). Слабким місцем застосовуваних нами індикаторів є те, що вони не здатні безпосередньо враховувати якість освітніх послуг та економічний виграш споживачів від їх отримання. Проте динаміка відносних цін (співвідношення зміни цін на продукти певної галузі із середнім рівнем споживчих цін) певною мірою відображає зміну якості продуктів галузі. Зокрема, фундаментальні положення досліджень споживацької поведінки передбачають, що якщо зростання цін супроводжується збільшенням частки видатків на відповідне благо в споживчому бюджеті, то це виражає більш високу цінність групи благ для споживачів [5-7].

Також не враховуватиме економічний виграш споживачів освітніх послуг через диференціацію доходів працівників з однаковим освітнім рівнем. Ми тлумачимо добробут лише в контексті поточних вигод: можливості споживати блага, бажані для споживачів, виходячи з їх уподобань та наявного бюджетного обмеження, проте не враховуємо можливості розширення споживання всіх благ у майбутньому, що відрізняє наш підхід від чисельних робіт у галузі людського капіталу [8; 9].

Нарешті, по-третє, зіставлення розмірів досягнутих цільових показників державної економічної діяльності по різних галузях, чи в різних економічних системах, трактується як основа оцінки якості інститутів (державної політики, процедур діяльності бюрократії, відповідності стимулів і мотивів, створених для чиновників цілям і завданням суспільства тощо). Для цього, може визначатись функціональна залежність між показниками обсягів задіяних державою для реалізації галузевих програм ресурсів і досягнутими цільовими показниками [9-11]. Випадки, що стають «аутлайєрами» (щодо окремих осередків використання ресурсів в межах програм з аналогічними цільовими показниками), розглядаються як такі, що зумовлені відхиленнями від поширеної 
«трендової» якості інститутів, регламентуючих використання ресурсного потенціалу програми. Гірші цільові показники, ніж передбачені трендом за фактичного рівня витрат, свідчать про наявність резервів підвищення ефективності завдяки інституціональним реформам. Кращі - про наявність вищої якості інститутів, ніж та, що стала основою визначення тренду. Відповідно, поширення такої якості інститутів на більші обсяги застосовуваних ресурсів слугуватиме фактором зростання середньої ефективності.

Мета статті - оцінити внесок бюджетного і комерційного секторів освіти у поліпшення забезпечення домогосподарств.

Виклад основного матеріалу. Для дослідження функціонального зв'язку між масштабами ресурсного забезпечення бюджетного і комерційного секторів освіти й обсягами ми сформулювали два масиви показників.

Перший - показники обсягів ресурсного забезпечення бюджетного і комерційного секторів освіти в Україні.

Ресурси комерційного сектору освіти в Україні формуються, переважно, витратами домогосподарств, оскільки участь бізнесу в фінансуванні інвестицій у людський капітал мінімальна, а витрати бюджетного сектору на освіту, навіть якщо їх одержують комерційні установи, розглядаємо як елементи фінансування бюджетного сектору. Останнє зумовлено тим, що переважну частку бюджетних витрат на освіту одержують саме установи, для яких провідну роль у ресурсному забезпеченні відіграють видатки бюджетів, а не кошти споживачів їхніх послуг.

Відповідно, для визначення номінального розміру витрат домогосподарств на придбання благ, що постачаються комерційним сектором освіти були використані дані про середні витрати в розрахунку на домогосподарство та кількість домогосподарств в Україні [12] (витрати і ресурси домогосподарств в Україні). Надалі отриманий добуток був переведений до річної розмірності та виражений у мільйонах гривень. Ця сума є визначальним джерелом ресурсів комерційного сектору освіти України.

Ресурси бюджетного сектору формуються витратами зведеного бюджету. Оскільки значна частина бюджетних видатків на освіту формує додану вартість не самих цих галузей, а галузей постачальників ресурсів для їх діяльності, то ми скористались не галузевою, а функціональною класифікацією видатків бюджету.

Таким чином, під «ресурсним забезпеченням бюджетного сектору галузі, що постачає певну категорію благ» розуміємо видатки зведеного бюджету України, що відповідають трьом умовам. По-перше, вони здійснюються в межах економічної діяльності урядових структур, а не в межах ви- конання загальнодержавних функцій. По-друге, сфера їх використання локалізована сукупністю етапів створення певної категорії благ, а не створенням доданої вартості певної галузі. Наприклад, витрати на оплату комунальних послуг державних освітніх закладів не належать до доданої вартості освіти, проте враховуються нами як витрати на ресурсне забезпечення створення пропонованих державою освітніх послуг. По-третє, ми маємо враховувати всі форми державної участі в розширенні пропозиції певної категорії благ: видатки на державне виробництво, державні закупівлі, субсидування кінцевих споживачів (якщо механізм здійснення не передбачає врахування субсидій у складі індивідуальних споживчих видатків домогосподарств), надання прямих субсидій виробникам тощо.

Відповідно, для оцінювання номінальних обсягів ресурсного забезпечення бюджетних секторів великих галузей соціальної сфери України були використані розміри видатків зведеного бюджету в річній розмірності за функціональною класифікацією (Розділ 0900 «ОСВІТА») [13].

Для переведення номінальних розмірів ресурсного забезпечення обох секторів освіти в реальні показники використано дефлятор ВВП. Це зумовлено тим, що ресурсне забезпечення створення благ, що постачаються галуззю «освіта», купується у виробників, належних до різних галузей. У подальших дослідженнях у разі виникнення потреби в уточненні тягаря інфляції, що несе окрема економічна галузь, звернемось до коефіцієнтів Леонтьєва, щоб визначити галузі, які виступають основними постачальниками ресурсів освіти й врахуємо індекси цін на продукцію цих галузей відповідно до їх питомої ваги в зовнішніх закупках освіти. Проте враховуючи традиційно високу питому вагу видатків на оплату праці в складі витрат освітніх закладів, можемо вважати, що провідний вплив на зростання вартості ресурсів галузі має динаміка заробітної плати ії̈ працівників. Поки отримуємо прийнятну точність розрахунків, використовуючи дефлятори ВВП.

На грунті отриманих показників розраховані базисні (2005 p. = 100 \%) індекси фізичних обсягів ресурсного забезпечення бюджетного і комерційного секторів освіти.

Другий масив показників - провідна характеристика забезпеченості домогосподарств благами, що постачає комерційний сектор освіти в Україні - реальні (виражені в цінах базового року) обсяги витрат домогосподарств на оплату благ, що постачаються комерційним сектором освіти (по роках ретроспективного періоду). Для переведення номінальних показників у реальні використані галузеві індекси цін за відповідні роки. На підставі цих значень розраховані базові $(2005$ р. $=100 \%)$ індекси зростання фізичних об- 
сягів споживання благ, що постачаються комерційним сектором освіти.

Така база даних дозволила оцінити параметри функції, що відбиває залежність темпів зростання фізичних обсягів споживання благ, що постачає комерційний сектор освіти від двох факторів: темпів зростання реальних ресурсів комерційного (X1) і бюджетного (X2) секторів цієї галузі. За логікою побудови вона аналогічна моделі Воркінга, але не передбачає логарифмичної форми представлення значень факторних змінних, бо і пояснювальні, і залежні змінні виражені в темпах зростання, що значно підвищує імовірність гіпотези про лінійний характер зв'язку та сталість абсолютних значень приростів у часі.

Модель Воркінга [14] активно застосовувалась для пояснення залежності змін у структурі споживання від доходів домогосподарств, до того як була розвинута в роботах Тейла, який інкорпорував до моделі терм для відображення впливу відносних цін [15]. Ми звернулись до первинної форми моделі Воркінга, бо додаємо до неї чинник, характер зв'язку якого з масштабами споживання аналогічний характеру впливу загальних доходів домогосподарств.

У нашій моделі залежна змінна $\left(Y_{1}\right)$ - базисні темпи зростання фізичних обсягів споживання благ, що комерційний сектор освіти постачає українським домогосподарствам; пояснювальна змінна $\left(X_{1}\right)-$ базисні темпи зростання реальних масштабів ресурсного забезпечення комерційного сектору галузі «освіта»; $\left(X_{2}\right)$ - базисні темпи зростання реальних масштабів ресурсного забезпечення бюджетного сектору галузі «освіта».

Математична специфікація функції має вигляд:

$$
Y_{1}=a_{0}+a_{1}{ }^{*} X_{1}+a_{2}{ }^{*} X_{2},
$$

де $a_{0}$ - вільний член функції, відбиває автономний, незалежний від включених у модель факторів темп зростання фізичних обсягів споживання благ, що постачає галузь «освіта»; $a_{1}-$ коефіцієнт біля змінної «базисні темпи зростання реальних масштабів ресурсного забезпечення комерційного сектору галузі «освіта» - відображає граничну зміну темпів зростання фізичних обсягів споживання внаслідок зміни темпів зростання реальних ресурсів комерційного сектору; $a_{2}-$ коефіцієнт біля змінної «базисні темпи зростання реальних масштабів ресурсного забезпечення бюджетного сектору галузі «освіта» - відображає граничну зміну темпів зростання фізичних обсягів споживання внаслідок зміни темпів зростання реальних ресурсів бюджетного сектору.

В основі трактування результатів оцінювання параметрів моделі такі принципи. По-перше, в разі існування відносин взаємозаміщення між благами, що постачають комерційний і бюджетний сектор галузі, коефіцієнт біля другої пояснювальної змінної має бути від’ємним. Відповідно, що більшою буде еластичність реакції залежної змінної на зміну другої пояснювальної - то більший потенціал бюджетного сектору виступатиме замінником благ, що постачає комерційний секTop.

Якщо ж між благами, що постачають комерційний і бюджетний сектори освіти існують відношення взаємодоповнення, то коефіцієнти біля обох пояснювальних змінних мають бути позитивними за знаком. При цьому співвідношення коефіцієнтів еластичності відображатиме порівняльну характеристику ефективності використання ресурсів у двох секторах галузі: що вищий коефіцієнт еластичності залежної змінної від пояснювальної, то, за інших рівних умов, вища ефективність використання ресурсів щодо нарощення обсягів споживання благ, що постачає відповідний сектор галузі.

Частинні коефіцієнти еластичності в моделі розраховуються за формулою:

$$
E_{i}=\frac{a_{i} \cdot \bar{x}_{i}}{\bar{Y}},
$$

де $a_{i}$ - оцінка параметру моделі; $x_{i}-$ середнє значення пояснювальної змінної за ретроспективний період; $Y$ - середнє значення залежної змінної за ретроспективний період.

Оскільки і залежна і пояснювальні змінні виражені в темпах зростання, то форма розрахунку середнього значення - середня геометрична.

Динаміку двох масивів досліджуваних показників (характеристик масштабів ресурсного забезпечення комерційного і бюджетного секторів освіти та забезпеченості домогосподарств благами, що постачає комерційний сектор освіти) протягом ретроспективного періоду (2005-2017) зображено на рис. 1.

Обсяги ресурсного забезпечення обох секторів освіти суттєво скоротились за ретроспективний період. Через бюджетні механізми фінансування галузь у 2017 р. одержувала лише 77,6 \% реального обсягу ресурсів, що надходили в 2005 р. А скорочення фінансування через комерційні механізми перевищило 40 \% (у 2017 р. реальні масштаби комерційного фінансування становили лише $58,0 \%$ рівня 2005 р.).

У результаті цих тенденцій частка бюджетного фінансування освіти зросла з 90,4 \% у 2005 р. до 92,6 \% у 2017 р., що свідчить про посилення вагомості бюджетних механізмів фінансування для української освіти протягом ретроспективного періоду.

При цьому реальні масштаби споживання благ, створюваних комерційним сектором освіти, стабільно демонстрували вищі темпи зростання 


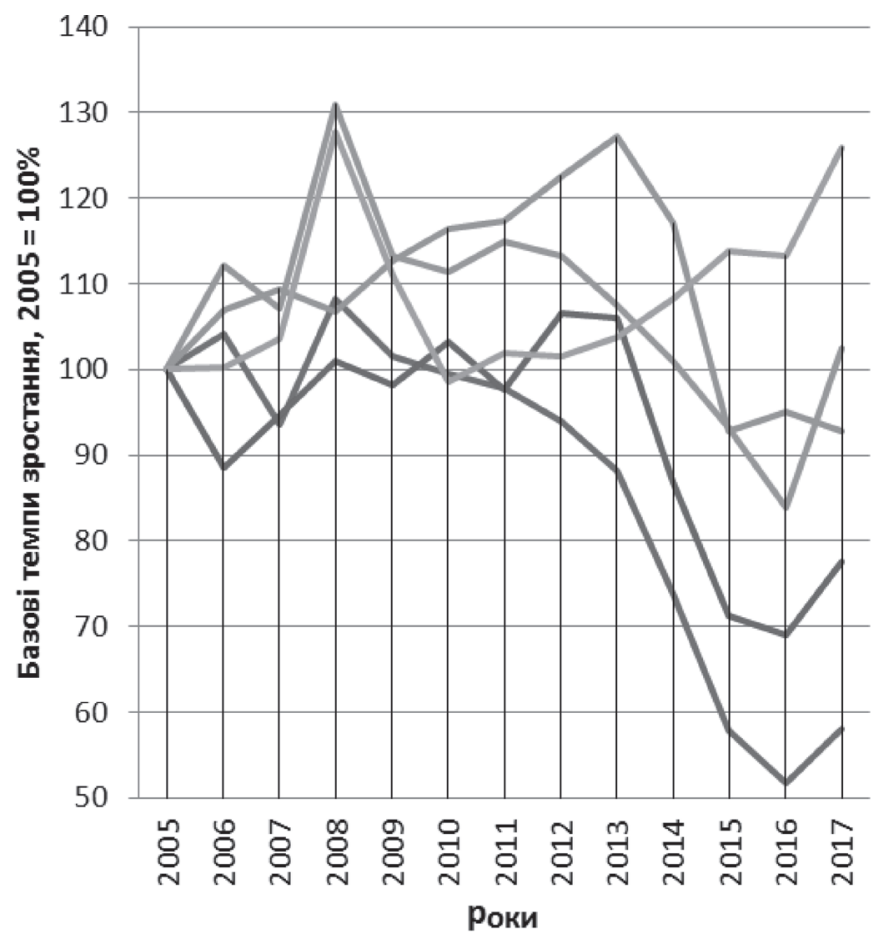

—— індекс зростання фізичних обсягів ресурсного

забезпечення комерційного сектору освіти

— індекс зростання фізичних обсягів ресурсного забезпечення бюджетного сектору освіти

— індекс зростання фізичних обсягів споживання благ, що постачає комерційний сектор освіти

— індекс зростання відносних цін благ, що постачає комерційний сектор освіти

Рис. 1. Динаміка реальних масштабів ресурсного забезпечення бюджетного і комерційного секторів освіти і характеристик споживання благ, що постачає комерційний сектор цієї галузі (авторська розробка)

(менші темпи скорочення) порівняно 3 показниками динаміки ресурсного забезпечення комерційного сектору освіти і за 2017 р. становили $102,5 \%$ обсягів 2005 p.

Наведене свідчить, що комерційний сектор освіти перебуває під тиском через відставання темпів зростання цін на його послуги від темпів інфляції в економіці. Це значить, що установи сектору позбавлені можливості перекласти тягар подорожчання ресурсів на споживачів своїх послуг через підвищення їх ціни. Відповідно, можна стверджувати, що в комерційному секторі освіти інтенсивність використання ресурсного забезпечення зростала протягом ретроспективного періоду: реальні темпи зростання обсягів споживання благ, створюваних сектором галузі, були вищими за реальні темпи зростання (скорочення) обсягів ресурсів, що вона отримувала.

Результати моделювання наведені в табл. 1.

Пояснювальна здатність моделі порівняно висока (близько 67 \% варіації залежної змінної пояснюється варіацією факторних, згідно з розміром коефіцієнта детермінаціі). Розмір критерію Фішера дозволяє визнати модель значущою (отримана оцінка коефіцієнта детермінації не випадкова і близько 70 \% варіації залежного параметра пояснюється варіацією факторних).

Ця модель (табл. 1) має формалізувати зв’язок між ресурсним забезпеченням двох секторів галузі й масштабами споживання іiі продукції. Відповідно, частинні коефіцієнти еластичності для кожної факторної змінної та знаки таких коефіцієнтів мають емпірично обгрунтувати відповідь

Результати моделювання для обсягів ресурсного забезпечення бюджетного і комерційного секторів освіти - як пояснювальних змінних та фізичних обсягів споживання - як залежної

\begin{tabular}{|c|c|c|}
\hline Parameters & $\begin{array}{c}\text { Parameter's } \\
\text { estimate }\end{array}$ & $t$-statistic \\
\hline$a_{0}$ & 60,918 & 3,623 \\
\hline$a_{1}$ & 0,426 & 2,073 \\
\hline$a_{2}$ & 0,099 & 0,313 \\
\hline$R^{2}$ & \multicolumn{2}{|c|}{0,670} \\
\hline$F$ & 10,15 (більше нормативного \\
за $p=0,05)$
\end{tabular}

на перші базові питання нашого дослідження: як пов'язані зміни ресурсного забезпечення двох секторів освіти з масштабами споживання благ, що постачаються галуззю? Чи спостерігається помітний вплив розширення чи звуження бюджетного фінансування охорони здоров'я на обсяги благ, надаваних галуззю, що купуються в комерційного сектору галузі?

Показово, що обидва коефіцієнти мають додатний знак, тобто за наявною базою даних, між благами, що постачають комерційний і бюджетний сектори освіти, наявні відносини взаємодоповнення, а не взаємозаміщення. Такі оцінки параметрів моделі можуть свідчити, що за явного переважання бюджетної освіти (частка бюджетного фінансування в загальних обсягах ресурсів галузі не опускалась нижче 90 \% протягом ретроспективного періоду) комерційна освіта має до- 
сить стабільний попит: існують послуги та споживачі, щодо яких можливості бюджетної освіти замістити послуги комерційної досить обмежені. При цьому і здатність комерційної освіти замістити переважну частку благ, створюваних на засадах бюджетного фінансування.

Великі, відносно значень параметрів, їхні стандартні похибки не дозволяють вважати отримані оцінки надійними (про це свідчать замалі розміри $t$-статистики). Проте можемо вважати велику відмінність між коефіцієнтами еластичності обсягів споживання до ресурсного забезпечення бюджетного і комерційного секторів не випадковою. Еластичність фізичних обсягів споживання благ, що постачаються комерційним сектором галузі «освіта» до ресурсів комерційного сектору, дорівнює 0,33 , тобто приріст реальних ресурсних можливостей комерційного сектору на $1 \%$ зумовлює розширення споживання його продукції більш ніж на 0,33\%. Стосовно ресурсів бюджетного сектору еластичність дорівнює 0,08, тобто розширення ресурсів бюджетного сектору на $1 \%$ зумовлює майже вчетверо менше скорочення споживання продукції комерційного сектору: додатковий відсоток ресурсів бюджетного сектору зменшує споживання продукції комерційного сектору на $0,08 \%$.

Значно вища еластичність залежного параметра від першої змінної навряд чи може трактуватись як ознака вищої ефективності використання ресурсів у комерційному секторі галузі. Динаміка ресурсного забезпечення комерційного сектору впливає на залежну змінну безпосередньо (відмінність між ними детермінована лише відставанням галузевого індексу цін від дефлятора ВВП), a ресурсне забезпечення бюджетного секторуопосередковано, лише створюючи більш чи менш прийнятну альтернативу споживанню продукції комерційного сектору.

Тому не можна трактувати цю оцінку в контексті суспільного ефекту, що може бути отримано внаслідок переміщення ресурсів між комерційним і бюджетним секторами галузі. Крім того, важливо врахувати, що провідна тенденція ретроспективного періоду- скорочення масштабів ресурсного забезпечення галузі як за рахунок видатків споживачів, так і за рахунок бюджетного фінансування. Відповідно, зв'язок, що формалізується в моделі, виражає швидше специфічну форму адаптації до негативних змін, ніж прояв розширення можливостей вибору споживачів. Розраховані коефіцієнти еластичності в жодному разі не мають трактуватись як ознака можливості одержання приросту суспільного ефекту від ресурсів, виділених галузі, шляхом їх перерозподілу від бюджетного фінансування на користь комерційного. Тим більше, що будь-які рішення щодо такого перерозподілу неможливі без враху- вання соціальних та морально-етичних аспектів. Закороткий ретроспективний період та вагомість багатьох факторів, що не були враховані в моделі, не дозволяють трактувати отримані кількісні значення еластичності як надійні для прогнозування наслідків руху ресурсів між бюджетним та комерційним секторами галузі.

Фактична структура споживчих видатків українських домогосподарств свідчить про їх перебування на тому етапі еволюції доходів і структури споживання, що розвинуті країни пройшли ще на початку XX ст. Відома фундаментальна залежність між зростанням доходів (споживчих витрат) і диверсифікацією структури таких видатків, що забезпечується, переважно, подоланням домінування витрат на харчування [16]. Саме в контексті цієї тенденції й встановлюється щільний зв’язок між зростанням доходів і розширенням споживання послуг загалом і послуг освіти зокрема. В багатьох роботах, присвячених динамці структури споживчих видатків, витрати на освіту класифікувались як блага розкоші, тобто масштаби їх споживання зростали швидше, ніж збільшувались реальні доходи [6]. Проте стосовно України ця універсальна закономірність має дуже специфічний характер прояву. Оскільки реальні розміри споживчих видатків не зростають, а скорочуються протягом достатньо тривалого періоду, розширення споживання благ, що постачаються комерційним сектором освіти, відбувається не завдяки, а всупереч динаміці доходів, як вимушена форма адаптації до згортання бюджетного фінансування державного сектору галузі.

Ураховуючи, що доступність послуг комерційного сектору освіти зростає (див. графік на рис. 1) можна стверджувати, що галузь вимушена обмежувати зростання цін на свої послуги нижче рівня інфляції, що не лише обмежує можливості іiі розвитку, а створює загрози для збереження досягнутого рівня якості освітніх послуг. Явище розмивання стандартів якості продуктів галузі $€$ вкрай небезпечним для суспільства i, на жаль, поширене в Україні стосовно галузей соціальної сфери, як форма адаптації до критичної нестачі ресурсів. Власне, уточнення форм прояву та суспільних наслідків тривалої деградації соціальної сфери, що спостерігається в Україні, стане предметом наших подальших досліджень.

Висновки. Отримані результати ілюструють такі характеристики зв'язку між коливаннями масштабів ресурсного забезпечення освіти і показниками споживання благ, що постачаються галуззю.

Масштаби ресурсного забезпечення, отримуваного галуззю як через бюджетне фінансування, так і через видатки домогосподарств, скорочувались протягом ретроспективного періоду, при цьому швидшими темпами скорочувались ресур- 
си комерційного сектору освіти (його частка в загальних ресурсах галузі скоротилась з 9,6 \% до 7,4 \%). Згортання масштабів сектору комерційної освіти на тлі хронічного недофінансування бюджетної є вкрай несприятливою тенденцією. По-перше, воно свідчить про негативну динаміку купівельної спроможності українських домогосподарств. По-друге, про відсутність (неефективність) механізмів фінансування освіти із залученням кредитних ресурсів та коштів бізнесу. По-третє, про зменшення стимулів для розвитку якості бюджетної освіти через послаблення конкурентного тиску потенційного блага замінника.

Ми не отримали емпіричного підтвердження здатності бюджетних витрат заміщати споживання благ, створюваних комерційним сектором освіти в Україні. Обидва сектори освіти вимушені функціонувати в режимі дефіциту ресурсів і несприятливої динаміки ресурсного забезпечення, що створює загрози розмивання якості освітніх послуг і підриває фундаментальні основи комерційного фінансування освіти: зв’язок «витати на освіту - зростання доходів».

Обидва сектори освіти явно потерпають від нестачі ресурсів - украй обмежені можливості бюджетів як домогосподарств, так і держави настільки обмежують вибір споживачів, що отримані нами результати коректніше трактувати як форми адаптації до негативної динаміки бюджетних обмежень, а не як прояв раціонального вибору споживача. Саме в такому контексті ми трактуємо і відсутність ознак ставлення домогосподарств до благ, що постачаються комерційним сектором освіти як до благ розкоші- протягом ретроспективного періоду питома вага видатків на освіту в складі доходів домогосподарств скорочується. Це вираження вкрай низьких економічних можливостей, а не споживчих уподобань українських домогосподарств, які вимушені витрачати близько половини своїх індивідуальних споживчих витрат на задоволення першочергових потреб, таких як їжа та комунальні послуги.

\section{Література}

1. Productivity Commission (2015). Efficiency in Health, Commission Research Paper, $162 \mathrm{p}$.

2. Batare, S. (2012). Efficiency of Public Spending on Education / Public Policy And Administration 2012, T. 11, Nr. 2 / 2012, Vol. 11, No 2, p. 171-186.

3. OECD (2010). Health care systems: Getting more value for money. OECD Economics Department Policy Notes, No. 2.

4. AHRQ Research to Reduce Cost and Improve the Quality of Health Care. Agency for Healthcare Research and Quality, Rockville, MD, 482 p.

5. Muhammad, A., James, L. S., Jr., Meade, B., and Regmi A. (2011). International Evidence on Food Consumption Patterns: An Update Using 2005 Inter- national Comparison Program Data, TB-1929. U. S. Dept.of Agriculture, Econ. Res. Serv. 53 p.

6. Clements, K. W., Wu, Y., \& Zhang, J. (2005). Comparing international consumption patterns. Empirical Economics, 31 (1).doi: 10.1007/s00181-0050012-y

7. Seale, J. L. Jr., Regmi, A. (2006). Modeling international consumption patterns. Review of Income and Wealth. Series 52, 4, 603-624.

8. Acemoglu, D., \& Pischke J.-S. (1999). The structure of wages and investment in general training. Journal of Political Economy, 107, 539-572. doi:10.3386/w6357.

9. Yang. X., \& Huang W. (2017). Human capital investment inequality and rural-urban income gap: evidence from China. Advances in Pacific Basin Business Economics and Finance. Emerald Publishing Limited. 165-182 p.

10. Bleakley, H. (2010). Health, human capital, and development. Annual Review of Economics, 2. doi: 10.1146/annurev.economics. 102308.124436.

11. Bloom, D., \& Canning, D. (2003). Health as human capital and its impact on economic performance. Geneva Papers on Risk and Insurance, 28 (2).

12. Витрати та ресурси домогосподарств України (2000-2017 роки). URL : www.ukrstat.gov.ua.

13. Витрати зведеного бюджету України (2000-2017 years). URL : www.ukrstat.gov.ua.

14. Working, H. (1943). Statistical Laws of Family Expenditure. Journal of the American Statistical Association, 38, 43-56.

15. Theil, H. (1987). The econometrics of demand systems. Applied demand analysis: Results from System-Wide Approaches Theil, $H$. and Klements, K. W. (eds.) Cambridge, MA: Ballinger Press, P. 148.

16. Chai, A., Rohde, N., \& Silber, J. (2014). Measuring the diversity of household spending patterns. Journal of Economics Surveys, 29 (3). doi: 10.1111/joes. 12066.

\section{References}

1. Productivity Commission (2015). Efficiency in Health, Commission Research Paper, 162 p.

2. Batare, S. (2012). Efficiency of Public Spending on Education / Public Policy And Administration 2012, T. 11, Nr. 2 / 2012, Vol. 11, No 2, p. 171-186.

3. OECD (2010). Health care systems: Getting more value for money. OECD Economics Department Policy Notes, 2.

4. AHRQ Research to Reduce Cost and Improve the Quality of Health Care. Agency for Healthcare Research and Quality, Rockville, MD, 482 p.

5. Muhammad, A., James, L. S., Jr., Meade, B., and Regmi A. (2011). International Evidence on Food Consumption Patterns: An Update Using 2005 International Comparison Program Data, TB-1929. U. S. Dept.of Agriculture, Econ. Res. Serv. 53 p. 
6. Clements, K. W., Wu, Y., \& Zhang, J. (2005). Comparing international consumption patterns. Empirical Economics, 31 (1).doi: 10.1007/s00181-005-0012-y.

7. Seale, J. L. Jr., Regmi, A. (2006). Modeling international consumption patterns. Review of Income and Wealth. Series 52, 4, 603-624.

8. Acemoglu, D., \& Pischke J.-S. (1999). The structure of wages and investment in general training. Journal of Political Economy, 107, 539-572. doi:10.3386/w6357.

9. Yang. X., \& Huang W. (2017). Human capital investment inequality and rural-urban income gap: evidence from China. Advances in Pacific Basin Business Economics and Finance. Emerald Publishing Limited. 165-182 p.

10. Bleakley, H. (2010). Health, human capital, and development. Annual Review of Economics, 2. doi: 10.1146/annurev.economics.102308.124436.

11. Bloom, D., \& Canning, D. (2003). Health as human capital and its impact on economic performance. Geneva Papers on Risk and Insurance, 28 (2).
12. State Statistics Service of Ukraine (2018). Vytraty ta resursy domohospodarstv Ukrainy (20002017 roky) [Household expenditures and resources of Ukraine (2000-2017)]. Retrieved from www.ukrstat. gov.ua.

13. State Statistics Service of Ukraine (2018). Vytraty zvedenoho biudzhetu Ukrainy (2000-2017 roky) [Consolidated Budget Expenditure of Ukraine (2000-2017)]. Retrieved from www.ukrstat.gov.ua.

14. Working, H. (1943). Statistical Laws of Family Expenditure. Journal of the American Statistical Association, 38, 43-56.

15. Theil, H. (1987). The econometrics of demand systems. Applied demand analysis: Results from System-Wide Approaches Theil, H. and Klements, K. W. (eds.) Cambridge, MA: Ballinger Press, P. 148.

16. Chai, A., Rohde, N., \& Silber, J. (2014). Measuring the diversity of household spending patterns. Journal of Economics Surveys, 29 (3). doi: 10.1111/joes. 12066.

УДК 631.158

\section{Н. О. Попова, \\ I. I. Княженко, I. C. Кубрак}

\section{СТАТИСТИЧНЕ ВИМІРЮВАННЯ СЕЗОННОСТІ ПРАЦІ У СІЛЬСЬКОМУ ГОСПОДАРСТВІ}

Анотація. У статті досліджено статистичні методи вимірювання сезонних коливань показників використання трудових ресурсів у сільському господарстві. Розраховані індекси сезонності та побудовані сезонні хвилі середньооблікової кількості штатних працівників, відпрацьованого робочого часу штатних працівників, середньої заробітної плати у сільському господарстві. Визначені шляхи зменшення сезонних коливань у сільському господарстві.

Ключові слова: сезонні коливання, сезонна хвиля, індекси сезонності, зайнятість, трудові ресурси, сільське господарство.

Summary. The article examines the methods of seasonal fluctuations in the use of labor resources in agriculture. The author calculated seasonal indices and built seasonal waves of the average number of full-time employees, the working hours of regular employees, and the average wage in agriculture. Directions for reducing seasonal fluctuations in agriculture are proposed.

Key words: seasonal fluctuations, seasonal wave, seasonality indices, employment, labor resources, agriculture.

$$
\text { DOI : } 10.33783 / 1977-4167-2019-46-2-104-110
$$

Постановка проблеми. У сучасних умовах існування аграрної економіки констатується специфічний характер зайнятості в сільському госпо-

дарстві. Це потребує вдосконалення управління процесами формування, використання, відтворення робочої сили.

(C) Н. О. Попова, I. І. Княженко, І. С. Кубрак, 2019

Бібліографія ДСТУ 8302:2015:

Попова Н. О., Княженко I. І., Кубрак I. С. Статистичне вимірювання сезонності праці у сільському господарстві. Вісник Бердянського університету менеджменту і бізнесу. 2019. № 2 (46). С. 104-110.

References (APA):

Popova, N. O., Kniazhenko, I. I., Kubrak, I. S. (2019). Statystychne vymiriuvannia sezonnosti pratsi u silskomu hospodarstvi [Statistical measurement of the seasonality of labor in agriculture]. Visnyk Berdianskoho universytetu menedzhmentu i biznesu, 2 (46), 104-110 (in Ukr.). 
Варто зазначити, що зайнятість у сільському господарстві завжди мала свої особливості, зумовлені передусім сезонністю виробництва та незбігом робочого періоду та періоду виробництва. Останнім часом проблема сезонності в сільському господарстві набуває дедалі більших масштабів. Керівники сільськогосподарських підприємств зацікавленні в отриманні швидкого та максимального прибутку, який можна одержати за рахунок, насамперед, рослинницьких галузей. Як зауважив професор О. М. Могильний у своїй доповіді на засіданні круглого столу «Сучасні проблеми ринку праці і зайнятості в контексті політики швидкого економічного зростання»: «За останні 28 років у структурі валової продукції сільськогосподарських підприємств відбулися небажані зміни: частка рослинництва (у постійних цінах 2010 р.) зросла на 18,7 \% (з 59,3\% у 1990 р. до $78 \%$ у 2016 р.), а тваринництва - зменшилась на таку саму величину, або удвічі (з 40,7 \% у 1990 р. до 22 \% у 2016 р.). Відповідно в рази було скорочено обсяг виробництва тваринницької продукції, ліквідовані тисячі робочих місць у галузі, де рівномірна постійна зайнятість працівників забезпечувалась упродовж усього календарного року. Тобто сезонність, як найбільш гостра проблема сільського ринку праці, була не такою відчутною для доходів сільських домогосподарств» [1, с. 10-11].

До того ж сезонність негативно позначається на розвитку економіки, спричиняє нерівномірність використання протягом виробничого року основних фондів, трудових ресурсів, продуктивності праці, збільшення втрат, підвищення собівартості продукції. 3 огляду на це, подолання сезонності - важливий резерв поліпшення використання матеріальних і трудових ресурсів, збільшення виробництва матеріальних благ, поліпшення забезпеченості населення товарами масового споживання. Зниження сезонності $€$ одним із найважливіших завдань удосконалення організації господарського управління в галузях сільського господарства, що зазнають сезонного впливу [2, с. 418].

Аналіз останніх досліджень і публікацій. Вагомий внесок у вивчення особливостей зайнятості населення в сільському господарстві зробили такі вчені, як: Н. Василенька, Т. Павлюк, О. Могильний та ін. Дослідженню сезонних коливань у сільському господарстві присвячено багато праць. Так, К. Д. Семенова оцінює сезонні коливання показників діяльності сільськогосподарського підприємства [3], Л. Зомчак та Г. Умриш досліджують проблему сезонності у виробництві м'яса та яєць [4], В. С. Міщенко розглядає проблему сезонності виробництва та збуту молока [5].

Проте немає розрахунків щодо сезонності використання трудових ресурсів у сільському гос- подарстві, тому саме це визначає актуальність обраної теми.

Мета статті - проаналізувати сезонність використання трудових ресурсів у сільському господарстві на основі статистичних методів та визначити напрями зниження сезонності сільського виробництва для того, щоб забезпечити максимальне збереження трудового потенціалу.

Виклад основного матеріалу дослідження. Формування аграрного ринку праці є нагальною потребою сільськогосподарських підприємств. Він дозволить забезпечити підприємства кадрами масових професій, особливо для комплектування кваліфікованої сезонної робочої сили. Треба зауважити, що регіональні ринки праці переважно сегментовані тільки на міське населення, без виділення аграрного ринку праці.

Утім сезонність використання трудових ресурсів у сільському господарстві може проявлятися в якості тільки сезонного використання робочої сили та у вигляді переважного використання окремих груп робітників в сезонний період.

Специфічною особливістю сільського господарства як виду економічної діяльності є значна тривалість природних процесів, що зазвичай не збігається з часом виробництва.

Як зазначає Н. Василенька, розрив між періодом виробництва і робочим періодом значно більший у рослинництві і дещо менший у тваринництві. Тому рівень використання працівників істотно залежить від виробничого напряму господарства [6]. Використання елементів процесу праці пов'язано з робочим періодом, тому для тваринництва характерно постійне споживання засобів виробництва і праці. В рослинництві припинення процесу праці супроводжується виключенням $з$ них матеріальних і трудових ресурсів i, отже, сезонним їх використанням.

Крім того, виникають додаткові труднощі, пов'язані з проблемою сезонності праці. Якщо в минулому сезонний обсяг робіт виконувався наявним у господарствах надлишком робочої сили, то зараз такий ресурс практично вичерпано. В результаті підвищення рівня інтенсивності сільськогосподарського виробництва, зниження приросту трудових ресурсів, інтенсивної міграції сільського населення проблема сезонності праці перетворилася з проблеми сезонного використання трудових ресурсів у проблему комплектування сезонної робочої сили. Обмежені можливості зниження сезонності праці в господарствах нині ставлять цю проблему на особливе місце.

Не можна й прогнозувати зниження сезонності використання трудових ресурсів в аграрному секторі, оскільки чинники, що лежать в основі нерівномірного споживання живої праці протягом року, зберігаються. В окремих господарствах сезонність 
може зрости, в інших - знизитися, але загалом рівень сезонності праціє доволі стабільним.

Розглянемо динаміку показників використання трудових ресурсів та визначимо індекси сезонності.

Показники динаміки кількості та частки середньооблікової кількості штатних працівників, зайнятих у сільському господарстві за період 2017-2019 рр. мають виражений сезонний характер, що видно з гістограм на рис. 1-2.

За даними Державної служби статистики України, у 2017 р. середньооблікова кількість штатних працівників коливалась від 354,2 у лютому до 438,3 тис. осіб у липні, збільшення у сезон становить 7,3

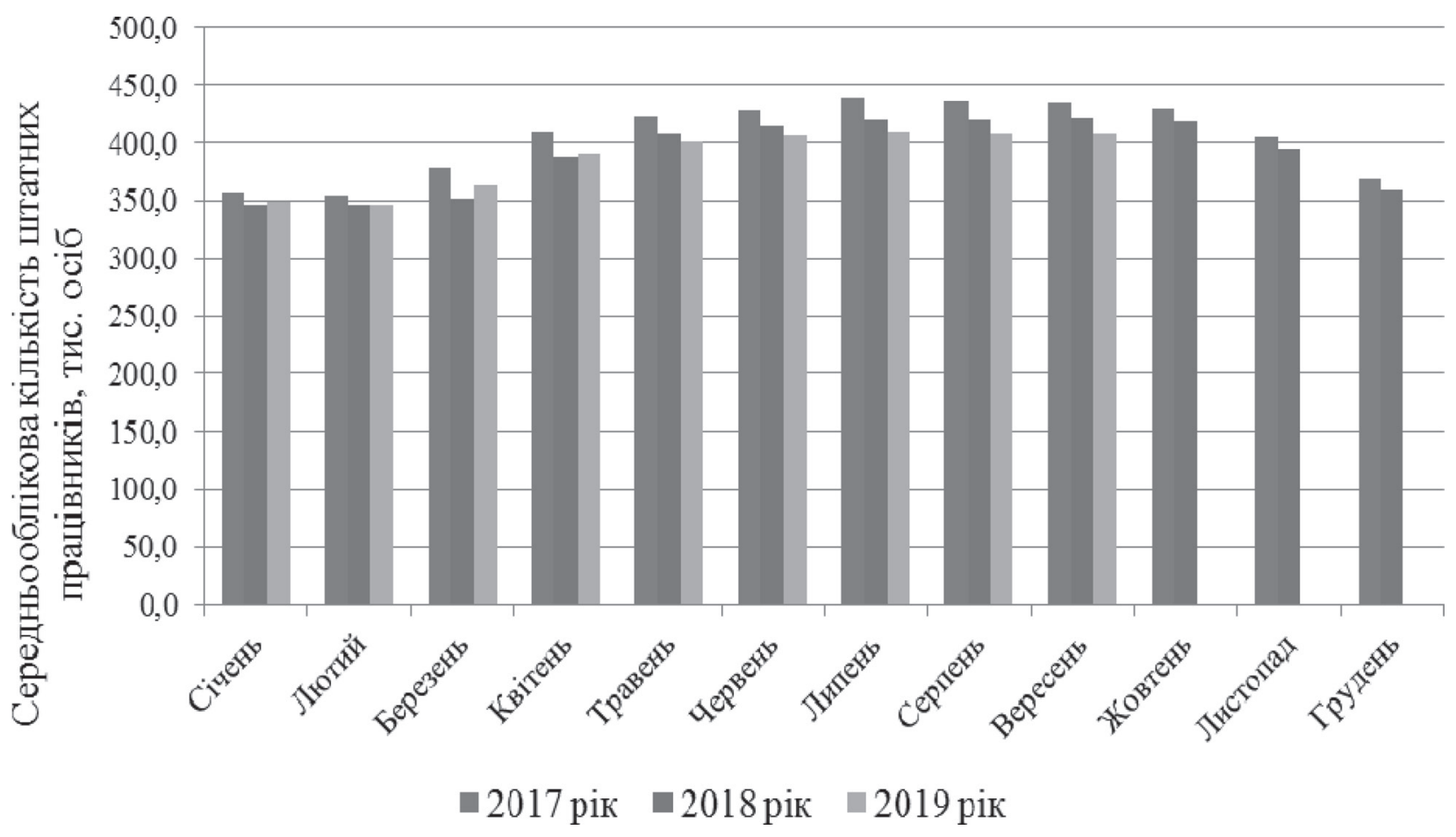

Рис. 1. Динаміка середньооблікової кількості штатних працівників у сільському господарстві за 20172019 рр., тис. осіб (побудовано за даними Державної служби статистики [7])

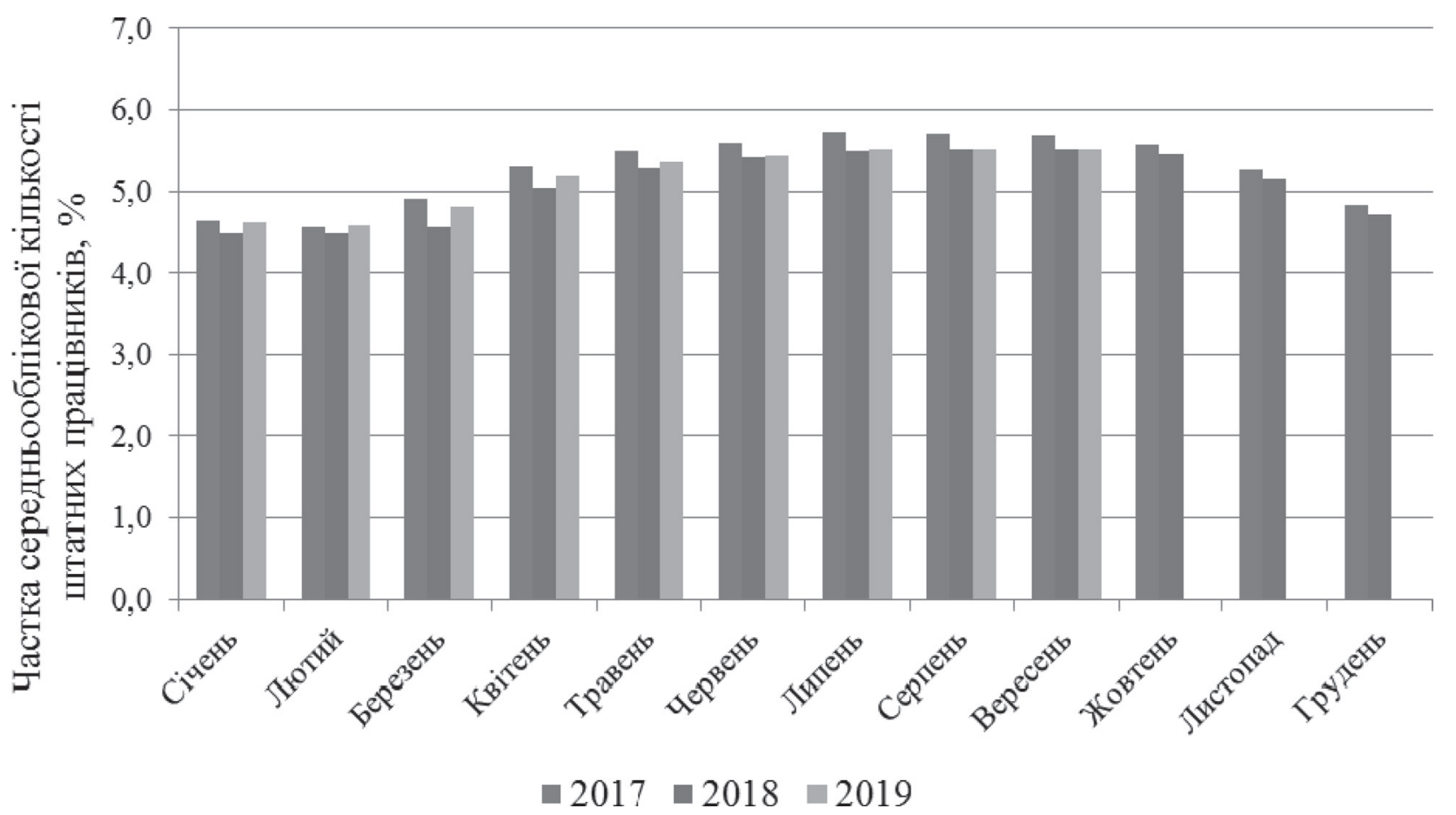

Рис. 2. Частка середньооблікової кількості штатних працівників у сільському господарстві у загальній чисельності за 2017-2019 рр., \% (розраховано та побудовано автором за даними Державної служби статистики України [7]) 
тис. осіб. У 2019 р. порівняно з 2017 р. відбувається зниження середньооблікової кількості штатних працівників, але сезонна хвиля зберігається, мінімальне значення припадає на лютий $-346,9$ тис. осіб, а максимальне 409,3 тис. осіб у липні.

Частка зайнятих у сільському господарстві неухильно знижується щороку, так у 2017 р. частка коливалась від 4,6 \% у лютому до 5,7 \% у липні, серпні, вересні, а у 2019 р. частка зайнятих була вже в межах від 4,6 \% до 5,5\%.
За даними Держкомстату, спостерігаємо збільшення кількості відпрацьованих годин штатними працівниками сільськогосподарських підприємств упродовж останніх трьох років, при зменшенні кількості штатних працівників. Це свідчить про підвищення продуктивності праці у сільському господарстві.

Дані рис. 3-4 підтверджують сезонність праці в сільському господарстві. Максимальне значення відпрацьованих годин упродовж трьох років припа-

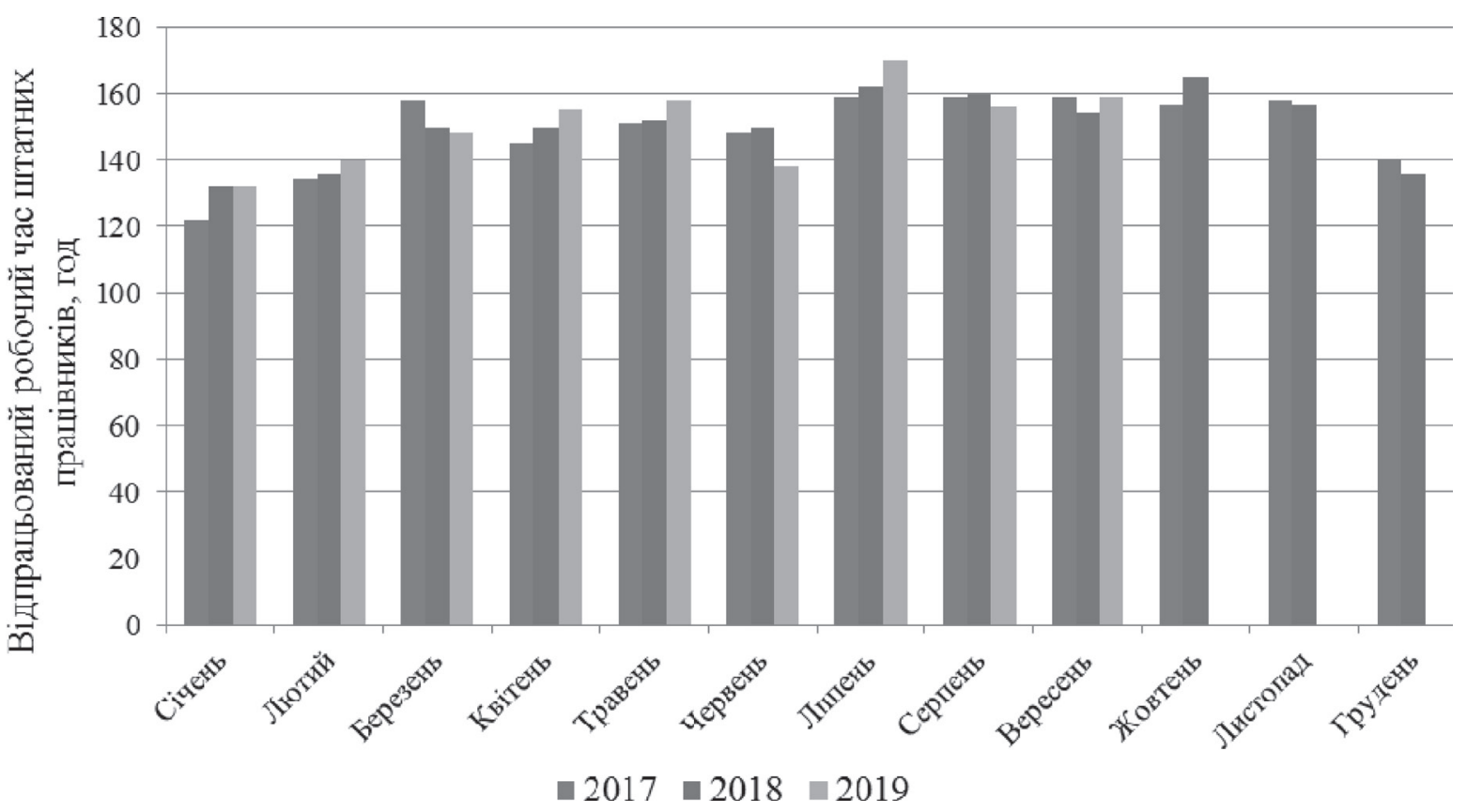

Рис. 3. Відпрацьований робочий час штатних працівників у сільському господарстві, год (побудовано за даними Державної служсби статистики України [8])

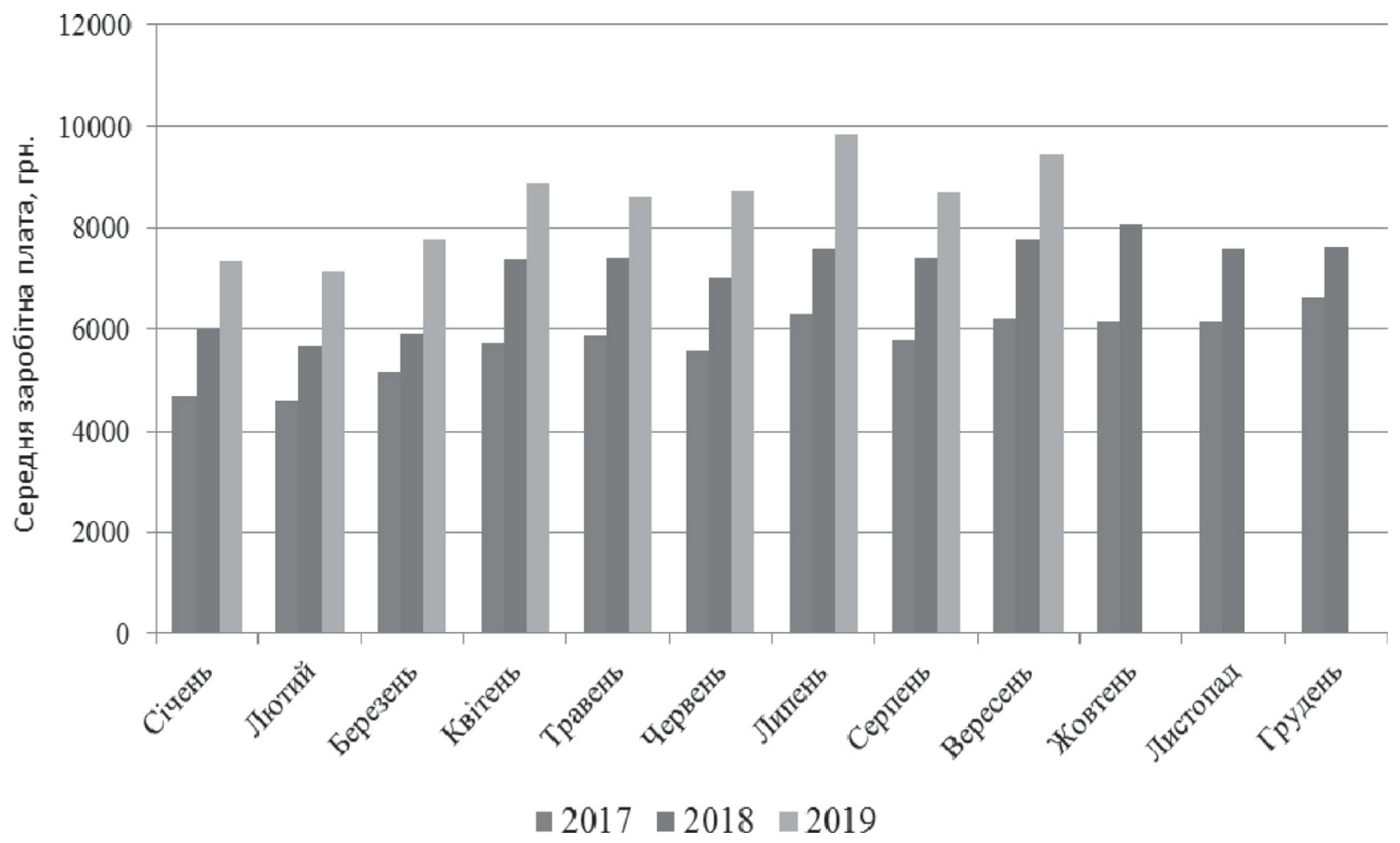

Рис. 4. Середня заробітна плата в сільському господарстві, грн (побудовано за даними Державної служби статистики України [9]) 
дає на липень (2017 р. - 159 год., 2018 р. - 162 год., 2019 р. - 170 год.), мінімальне на січень (2017 р. 122 год., 2018 р. - 132 год., 2019 р. - 132 год.).

Наразі статистичні методи дозволяють вивчати сезонні коливання кількісно. Для цього розраховують індекси сезонності - як відношення середньомісячного рівня за декілька років до загального середнього рівня.
Вихідною інформацією слугують щомісячні показники використання трудових ресурсів у сільському господарстві, а саме: середньооблікова кількість штатних працівників, відпрацьований робочий час штатних працівників, середня заробітна плата в сільському господарстві (табл. 1).

Сезонні хвилі вищезазначених показників зображені на діаграмі рис. 5.

Таблиия 1

Розрахунок індексів сезонності показників використання трудових ресурсів сільського господарства за 2017-2019 рр. (розраховано автором за даними Державної служби статистики України $[7,8,9]$ )

\begin{tabular}{|c|c|c|c|c|c|c|}
\hline \multirow[b]{2}{*}{ Місяць } & \multicolumn{3}{|c|}{ Середні значення за період 2017-2019 рр. } & \multicolumn{3}{|c|}{ Індекси сезонності, \% } \\
\hline & $\begin{array}{c}\text { Середньооблі- } \\
\text { кова кількість } \\
\text { штатних праців- } \\
\text { ників, тис. осіб }\end{array}$ & $\begin{array}{c}\text { Відпрацьова- } \\
\text { ний робочий час } \\
\text { штатних праців- } \\
\text { ників, год. }\end{array}$ & $\begin{array}{c}\text { Середня } \\
\text { заробітна } \\
\text { плата, грн. }\end{array}$ & $\begin{array}{c}\text { Середньооблі- } \\
\text { кова кількість } \\
\text { штатних праців- } \\
\text { ників }\end{array}$ & $\begin{array}{c}\text { Відпрацьований } \\
\text { робочий час штат- } \\
\text { них працівників }\end{array}$ & $\begin{array}{c}\text { Середня } \\
\text { заробітна } \\
\text { плата }\end{array}$ \\
\hline Січень & 351,0 & 128,7 & 6010,8 & 88,8 & 85,7 & 86,0 \\
\hline Лютий & 349,3 & 136,7 & 5802,7 & 88,4 & 91,0 & 83,0 \\
\hline Березень & 364,4 & 152,0 & 6283,3 & 92,2 & 101,2 & 89,9 \\
\hline Квітень & 396,0 & 150,0 & 7324,7 & 100,2 & 99,9 & 104,8 \\
\hline Травень & 410,4 & 153,7 & 7290,7 & 103,9 & 102,3 & 104,3 \\
\hline Червень & 416,7 & 145,3 & 7110,7 & 105,5 & 96,8 & 101,7 \\
\hline Липень & 422,8 & 163,7 & 7909,0 & 107,0 & 109,0 & 113,1 \\
\hline Серпень & 421,7 & 158,3 & 7302,7 & 106,7 & 105,4 & 104,4 \\
\hline Вересень & 421,5 & 157,3 & 7808,2 & 106,7 & 104,7 & 111,7 \\
\hline Жовтень & 424,4 & 161,0 & 7105,5 & 107,4 & 107,2 & 101,6 \\
\hline Листопад & 400,1 & 157,5 & 6864,5 & 101,3 & 104,9 & 98,2 \\
\hline Грудень & 363,9 & 138,0 & 7127,6 & 92,1 & 91,9 & 101,9 \\
\hline $\begin{array}{l}\text { Усереднене } \\
\text { значення }\end{array}$ & 395,1 & 150,2 & 6992,0 & $\mathrm{x}$ & $\mathrm{X}$ & $\mathrm{x}$ \\
\hline
\end{tabular}

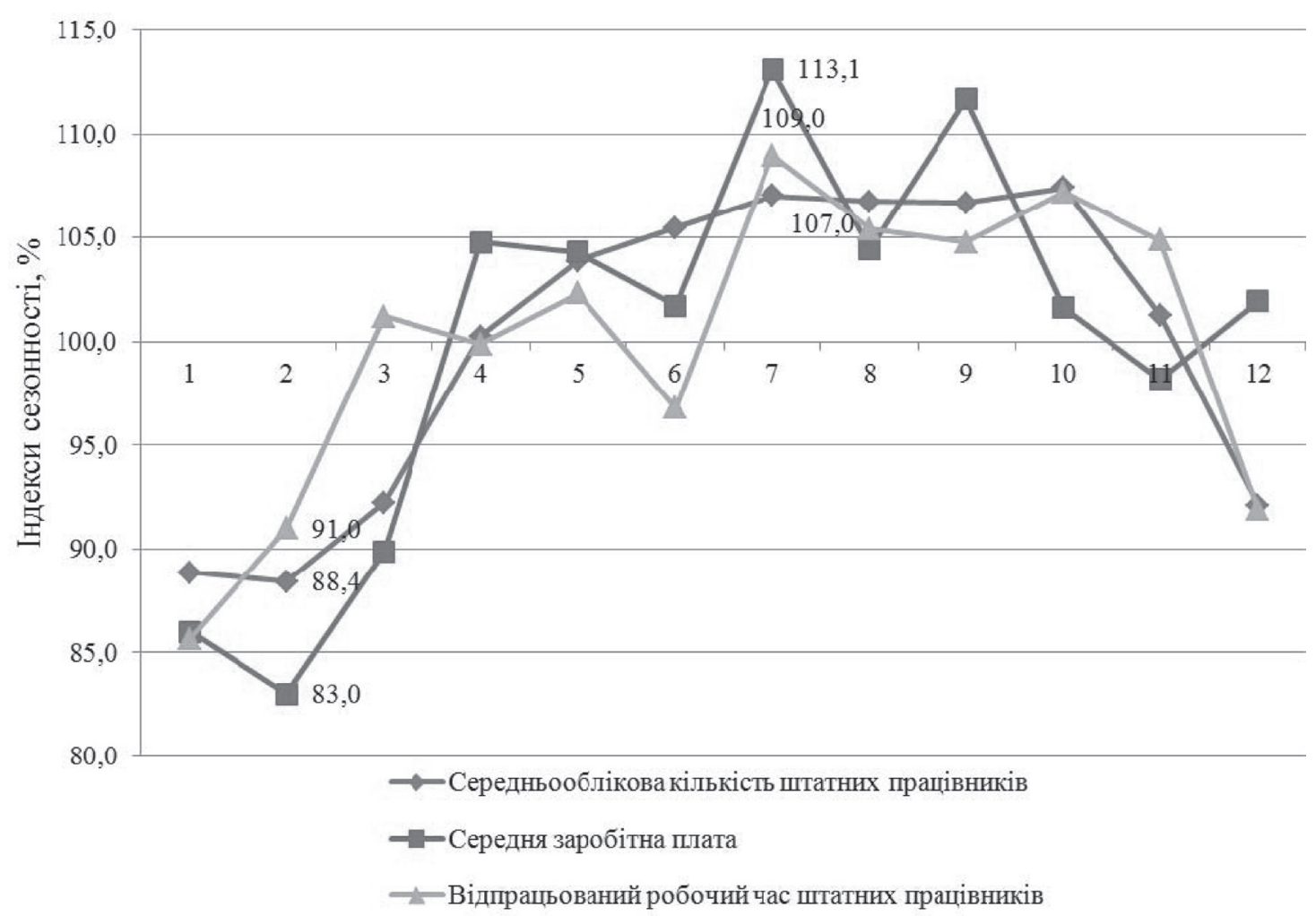

Рис. 5. Сезонні хвилі середньооблікової кількості штатних працівників, середньої заробітної плати та відпрацьованого робочого часу штатних працівників за 2017-2019 рр. (побудовано за даними табл. 1) 
Розрахунки табл. 1 та сезонні хвилі на рис. 4 свідчать про те, що найбільші значення індекси сезонності набувають у липні - жовтні. У січні лютому індекси сезонності мають найменші значення.

Висновки. Загальновідомо, що сезонність має значний вплив на використання ресурсного потенціалу, організацію виробничого процесу і загалом на результативність діяльності підприємств сільського господарства.

Отже, у зв'язку з сезонністю сільського господарства виникає необхідність формування робочої сили з різною тривалістю іiї функціонування у виробництві. Для сільського господарства потрібна, з одного боку, постійна робоча сила для цілорічного виконання певного обсягу робіт. 3 іншого боку, для виконання в сезонний період різних сільськогосподарських робіт з'являється потреба мати сезонну робочу силу.

Наразі використання в сільському господарстві сезонної робочої сили зумовлено не тільки рівнем сезонності праці, а й забезпеченістю господарств постійною робочою силою, рівнем iii використання. Однак зниження сезонної робочої сили не повинно бути самоціллю, це може призвести до розтягування термінів виконання сільськогосподарських робіт і втрат продукції. Залежно від виробничої необхідності, розрив у використанні праці між літнім і зимовим періодами може бути навіть збільшено, якщо це відповідає інтересам працівників і виробництва. Такий підхід $€$ одним з резервів зниження використання в сільському господарстві сезонної робочої сили.

Ще одним напрямом зниження сезонності праці в сільському господарстві є розвиток позааграрної зайнятості на селі, яка залучить трудові ресурси в міжсезоння та знівелює фактор сезонності. Згладжування сезонності використання робочої сили $є$ значним фактором поліпшення соціального стану сільського населення та збереження трудового потенціалу.

\section{Література}

1. Могильний О. М. Ринок праці сільської місцевості: стан та перспективи розвитку в умовах децентралізації. Сучасні проблеми ринку праці $i$ зайнятості в контексті політики швидкого економічного зростання: матер. засідання круглого столу (17 трав. 2018 р., м. Київ) / за наук. ред. С. М. Кожем’якіної. К.: ІПКДСЗУ. 2018. 54 с.

2. Павлюк Т. І. Особливості зайнятості населення в сільському господарстві. Глобальні ma національні проблеми економіки. 2018. Вип. 23. C. 415-420.

3. Семенова К. Д. Оцінка сезонних коливань показників діяльності підприємств. Вісник соціально-економічних досліджень. 2007. Вип. 25. C. 311-315.
4. Зомчак Л., Умриш Г. Моделювання й прогнозування виробництва м'яса та яєць в Україні за допомогою сезонної ARIMA-моделі. Agricultural and resource economics: international scientific e-journal. 2017. № 3. C. 16-27.

5. Міщенко В. С. Вплив сезонності на виробництво продукції молочного скотарства. $\mathrm{Ha-}$ уковий вісник Міжнародного гуманітарного університету. Серія: Економіка і менеджмент. 2016. Вип. 18. С. 77-79.

6. Василенька Н. Особливості розвитку та специфіка використання персоналу в аграрній сфері. Аграрна економіка. 2012. Т. 5. № 1-2. C. 76-81.

7. Середньооблікова кількість штатних працівників за видами економічної діяльності / Державна служба статистики України. URL : http://www.ukrstat.gov.ua/operativ/operativ2018/ gdn/Sok_ed/Arch_sok_ed_u.htm (дата звернення: 10.11.2019).

8. Відпрацьований робочий час штатних працівників за видами економічної діяльності / Державна служба статистики України. URL : http:// www.ukrstat.gov.ua/operativ/operativ2018/gdn/ Vrch_ed/Arch_vrch_ed_u.htm (дата звернення: 08.11.2019).

9. Середньомісячна заробітна плата за видами економічної діяльності / Державна служба статистики України. URL : http://www.ukrstat.gov.ua/ operativ/operativ2005/gdn/Zarp_ek_p/Zp_ek_p_u/ arh_zpp_u.htm (дата звернення: 08.11.2019).

\section{References}

1. Mogylnyj O. M. (2018) Rynok praci silskoyi miscevosti: stan ta perspektyvy rozvytku $v$ umovax decentralizaciyi [Rural labor market: state and prospects of development in decentralized conditions]. Kyiv (in Ukr.).

2. Pavliuk T. I. (2018). Osoblyvosti zainiatosti naselennia $v$ silskomu hospodarstvi [Features of employment of the population in agriculture]. Visnyk Mykolaivskoho natsionalnoho universytetu imeni V. O. Sukhomlynskoho, 23, 415-420 (in Ukr.).

3. Semenova K. D. (2007). Ocinka sezonnyx kolyvan pokaznykiv diyalnosti pidpryyemstv [Estimation of seasonal fluctuations of enterprise activity indicators]. Visnyk socialno-ekonomichnyx doslidzhen, 25, 311-315 (in Ukr.).

4. Zomchak L. \& Umrysh G. (2017). Modelyuvannya j prognozuvannya vyrobnycztva myasa ta yayecz $v$ Ukrayini za dopomogoyu sezonnoyi ARIMAmodeli [Modeling and forecasting of meat and eggs producing in Ukraine with seasonal ARIMA-model]. Agricultural and resource economics: international scientific e-journal, 3, 16-27 (in Ukr.).

5. Mishhenko V. S. (2016). Vplyv sezonnosti na vyrobny'cztvo produkciyi molochnogo skotarstva [Seasonal prevalence in cattlebreeding]. Naukovyj visnyk 
Mizhnarodnogo gumanitarnogo universytetu. Seriya: Ekonomika i menedzhment, 18, 77-79 (in Ukr.)

6. Vasylenka, N. (2012). Osoblyvosti rozvytku ta specyfika vykorystannya personalu v agrarnij sferi [Personnel development and usage peculiarities in agrarian sphere]. Agrarna ekonomika, T. 5, 1-2, 76-81 (in Ukr.).

7. State Statistics Service of Ukraine. Serednjooblikova kiljkistj shtatnih pracivnikiv za vidami ekonomichnoji dijaljnosti [Direct investments (share capital) in the economy of Ukraine / from Ukraine by types of economic activity]. Available at: http://www. ukrstat.gov.ua/operativ/operativ2018/gdn/Sok_ed/ Arch_sok_ed_u.htm (accessed date 08.11.2019)
8. State Statistics Service of Ukraine. Vidpracjovanij robochij chas shtatnih pracivnikiv za vidami ekonomichnoji dijaljnosti [Direct investments (share capital) in the economy of Ukraine / from Ukraine by types of economic activity]. Available at : http://www. ukrstat.gov.ua/operativ/operativ2018/gdn/Vrch_ed/ Arch_vrch_ed_u.htm (accessed date 08.11.2019)

9. State Statistics Service of Ukraine. Serednjomisjachna zarobitna plata za vidami ekonomichnoji dijaljnosti [Direct investments (share capital) in the economy of Ukraine / from Ukraine by types of economic activity]. Available at : http://www.ukrstat. gov.ua/operativ/operativ2005/gdn/Zarp_ek_p/Zp_ ek_p_u/arh_zpp_u.htm (accessed date 08.11.2019). 


\title{
РОЗВИТОК ПРОДУКТИВНИХ СИЛ І РЕГІОНАЛЬНА ЕКОНОМІКА
}

\author{
УДК 3338.48:332.1(075.8)

\section{КЛАСТЕРИЗАЦІЯ ЯК ІННОВАЦІЙНА ПЕРЕВАГА У ФУНКЦІОНУВАННІ ТА УПРАВЛІННІ РЕГІОНАЛЬНОЮ ГАЛУЗЗЮ ТУРИЗМУ}

O. А. Марченко

Анотація. У статті розглянуті кластерні підходи як основна перевага удосконалення механізмів функціонування та управління туристичної індустрії на рівні країни та регіону. Проаналізовані складові кластерних механізмів управління, обгрунтовано їх інноваційний характер. Запропоновано комплекс заходів для створення сприятливих умов розвитку туристичних кластерів.

Ключові слова: кластеризація, інноваційні підходи, туристичний кластер, туристична галузь, механізми функціонування.

Summary. The cluster approaches as the main advantage of the improvement of the mechanisms of the functioning and the management of the tourism industry at the country and the region level are considered in the article. The components of the cluster mechanisms of the management are analyzed; their innovative character is substantiated. The complex of the measures of the creation of the favorable conditions of the development of the tourist clusters is proposed.

Key words: clustering, innovative approaches; tourist cluster; tourism industry; mechanisms of functioning.

$$
\text { DOI : 10.33783/1977-4167-2019-46-2-111-115 }
$$

Постановка проблеми. В умовах висококонкурентного ринку та поширення ролі глобальних корпорацій більшість підприємств змушені шукати шляхи інтеграції для реалізації цілей підприємницької діяльності. Однією з перспективних форм економічної інтеграції є формування інноваційних кластерів, які являють собою групи підприємств, фірм, організацій та установ, діяльність яких знаходиться в одній (чи споріднених) сферах бізнесу за економічними інтересами та регіональною ознакою. Перевага і новизна кластерного підходу полягають у тому, що він надає високої значущості макроекономічній складовій, а також територіальному і соціальному аспектам економічного розвитку.

Сьогодні кластеризація є тією формою внутрішньої інтеграції та кооперування, що здатна забезпечити як стійкість, так і синергетичний ефект протидії тиску глобальної конкуренції 3 боку монопольних транснаціональних корпорацій (ТНК). Найважливішим показником діяльності кластерів є забезпечення високої конкурентоспроможності їх продукції на ринку. Тому кластерний розвиток туристичних дестинацій як окремих регіонів країни є однією з характерних ознак сучасної інноваційної економіки туризму. Крім того, кластери являють собою таку комбіна- цію конкуренції та кооперації, коли об’єднання в одних сферах допомагає успішно вести конкурентну боротьбу в інших.

Аналіз останніх досліджень і публікацій. Дослідженням економічних кластерів були присвячені публікації К. Адамова, Ю. Арутюнова, А. Александрової, Е. Бєлякової, Ю. Ковальова, I. Пилипенка, українських учених-регіоналістів: К. Андрющенка, М. Войнаренка, В. Бондаренка, О. Дейнека, В. Демченка, О. Крайника, Н. Мартишенка, Д. Стеченка, С. Соколенка, А. Требуха, Г. Михайліченка. Результатом їхніх досліджень стали моделі кластерних угрупувань природної чи культурної спадщини, освітніх установ, об'єктів туристичної інфраструктури, проєктних і наукових організацій, аргументовано доведені роль та місце кластерів у розвитку регіональних економічних систем, зокрема туристичних.

Мета статті - розглянути та проаналізувати кластерні підходи в удосконаленні механізмів функціонування та управління туристичною індустрією; обгрунтувати інноваційний характер кластерних механізмів управління.

Виклад основного матеріалу дослідження. Важливим чинником забезпечення економічного зростання країни та іiі регіонів залишається туристична діяльність. Експерти відзначають постійне

(C) О. А. Марченко, 2019

Бібліографія ДСТУ 8302:2015:

Марченко О. А. Кластеризація як інноваційна перевага у функціонуванні та управлінні регіональною галуззю туризму. Вісник Бердянського університету менеджменту і бізнесу. 2019. № 2 (46). С. 111-115.

References (APA):

Marchenko, O. A. (2019). Klasteryzatsiia yak innovatsiina perevaha $v$ funktsionuvanni ta upravlinni rehionalnoiu haluzziu turyzmu [Clustering as an innovative advantage in functioning and managing the regional industry of tourism]. Visnyk Berdianskoho universytetu menedzhmentu i biznesu, 2 (46), 111-115 (in Ukr.). 
зростання іiі ролі у структурі глобальної економіки. На індустрію туризму припадає до $10 \%$ світового валового національного продукту, $11 \%$ світових споживчих витрат. Туристична галузь входить до трьох найбільш високоефективних та конкурентоспроможних галузей.

Світові економічні тенденції та особливості розвитку туристичної сфери на сучасному етапі визначають появу якісно нових умов господарювання $з$ принципово новим характером економічних зв’язків і економічних відносин, вимагають інноваційного підходу до методів взаємодії між владою, бізнесом та громадськими інституціями. Серед найбільш ефективних форм інноваційного економічного розвитку закордонні та вітчизняні фахівці відзначають кластерний підхід до структурування економіки, обгрунтування стратегій національної та регіональної економічної політики й підвищення конкурентоспроможності продуктів та послуг. Тому вивчення можливостей і досвіду запровадження кластерної моделі організації туристичної діяльності є перспективним та актуальним.

Механізми ефективного функціонування кластера забезпечують умови, які сприяють руху інформації і координації інтересів горизонтально і вертикально пов'язаних підприємств. Зумовлено це географічною близькістю, а також зв'язками, що виникають у наукових співтовариствах, професійних асоціаціях, нормами поведінки і вірою в тривалі і міцні взаємини [1, с. 86].

Кластерна технологія забезпечує можливість ведення конструктивного i ефективного діалогу між спорідненими організаціями, їх постачальниками і владою. Спрямовані на поліпшення умов функціонування кластера, державні інвестиції приносять користь одразу багатьом компаніям. Завдання влади при цьому - виявити основні кластери, у яких зацікавлений регіон, через формування інституціонального механізму в законодавчому плані, об'єднання наявного інтелектуального і науково-освітнього потенціалу, матеріально-технічних та інших ресурсів, визначення стратегічних основ розвитку [2, с. 144].

У проєкті Концепції створення кластерів в Україні визначено чотири види кластерів, зокрема туристичний кластер, а в проєкті Концепції національної стратегії формування та розвитку транскордонних кластерів наголошено на пріоритетності формування транскордонних туристичних кластерів. На жаль, ці документи поки що не отримали схвалення Верховної Ради України, проте започаткували процес формування інституційного середовища для реалізації кластерної моделі розвитку економіки України.

Світова практика переконує, що в становленні та функціонуванні кластерів важливу роль відіграють наукові та освітні установи (найчастіше навчальні заклади), тому, враховуючи законодавчі обмеження, які існують в Україні для вищих навчальних закладів стосовно можливості ведення господарської діяльності, кластери в Україні за участі навчальних закладів можна створювати у вигляді інноваційної структури Б-виду. Формування конкурентоспроможного туристичного кластера приводить до створення та просування бренду дестинації як одиниці кластера [3, с. 86].

Однією зі складових кластерних механізмів удосконалення регіональної структури галузі туризму є кластерна ініціатива. Вона визначається як організована спроба збільшити темпи зростання і конкурентоспроможність кластера в певному регіоні, залучаючи до проєкту кластерні фірми, державу і дослідні інститути. У своїй багатокомпонентній основі туристичний кластер формує додатковий синергетичний та компліментарний актив завдяки:

- координації сумісних дій, посиленню обміну інформацією, досвідом, інноваційними технологіями, сумісному використанню обслуговуваних інфраструктурних об’єктів дестинації;

- підготовці та підвищенню кваліфікації кадрів туристичного супроводу й обслуговування;

- можливості реально порівняти роботи фірм-конкурентів, ефективності їхньої діяльності;

- наявності трудових ресурсів відповідної кваліфікації;

- застосуванню особливих режимів оподаткування, інвестування, соціальних ініціатив;

- інституційна підтримка правовому регулюванню, наданню субвенцій.

На території України діють територіальнорекреаційно-туристичні комплекси (кластери), відомі ще за радянських часів: Трускавець, Моршин, Миргород, які об'єднують свої зусилля 3 просування продукту дестинації, сформованого на основі природних джерел та ресурсів санаторно-курортного комплексу. Однак сьогодні є багато успішних кластерних утворень у сфері туризму пізнавального, пригодницького та етнографічного типів:

- Кам'янець-Подільський туристичний кластер, кластер «Оберіг» (Хмельницька область);

- кластер «Вознесенськ» (частина «Південного золотого кільця України»);

- туристично-рекреаційний кластер «Дністровський каньйон» (Тернопіля);

- кластери сільського зеленого туризму Одещини, Херсонщини, Закарпаття та ін., які доводять своїм існуванням ефективність державного-приватного партнерства заради досягнення мети - сталого розвитку туризму в регіоні, якісного надання туристичних послуг, стимулювання попиту та підтримання його належного рівня, забезпечення робочими місцями місцевих жителів.

Повноцінно функціонуючим кластером можна назвати лише курортополіс «Трускавець», який 
не втратив інноваційної складової (лише завдяки ініціативі окремих особистостей-інноваторів), та має сформований бренд «дестинації курортного типу». Основою формування кластера, окрім ресурсного потенціалу, повинен стати його інноваційний потенціал. На рис. 1 наведено модель туристичного кластера, яка побудована на інноваційній основі, формує його додатковий капітал (в окремих випадках - репутаційний капітал) як привабливу дестинацію, що розвивається за інтенсивною моделлю інноваційного розвитку з використанням новітньої інформаційно-комуніка-

Кластерна логіко-структурна модель організації туристичного господарства

Стимулювання нових форм просторової організачії сфери послуг, координація дій державних органів влади, малого та середнього бізнесу, освітніх та наукових установ

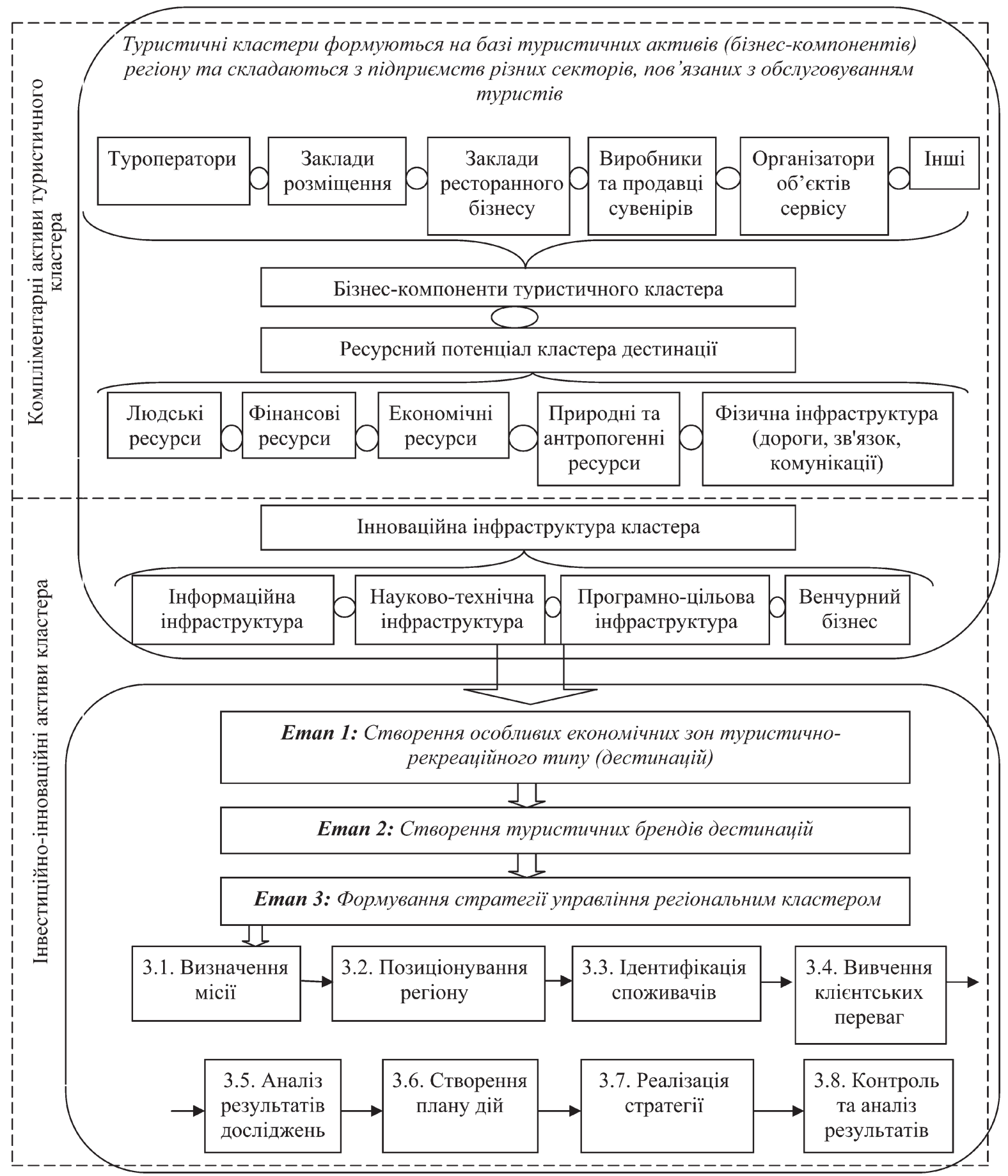

Рис. 1. Модель регіонального туристичного кластера, побудованого на інноваційній основі [1] 
ційної, науково-технічної та програмно-цільової інфраструктури, розвитку венчурного бізнесу та сприятливих умов його процвітання [1, с. 156].

Завдяки теоретико-аналітичним викладенням та змістовим наповненням сформуємо дефініції:

1. Інноваційна туристична система - це компліментарні активи виробництва туристичного продукту, які містять підприємства різних секторів, пов'язані з обслуговуванням туристів, тобто підприємства-продуценти, організатори об'єктів сервісу, виробники туристичних сувенірів.

2. Інноваційна туристична інфраструктура - це сукупність туристичних кластерів; туристичних технопарків (переважно на курортологічних засадах); науково-інноваційних бізнес-інкубаторів; венчурних туристичних підприємств; туристичних центрів комерційного розвитку туризму.

Метою створення особливих економічних зон туристично-рекреаційного типу є залучення інвестицій, активізація підприємництва, підвищення ефективності використання туристичнорекреаційних ресурсів та конкурентоспроможності туристичного статусу регіону; можливість активізації спеціалізованого туристичного підприємництва в кожному кластері для збалансованого розвитку всієї туристично-рекреаційної системи.

Кластери в галузі туризму є формою регіонального об'єднання підприємств туризму та суміжних галузей, використання комплексоутворювальних туристично-рекреаційних ресурсів на умовах горизонтальної та вертикальної інтеграцій, розміщених на компактній території. Вони сприяють раціональній трансформації або реструктуризації галузі туризму, оскільки є джерелом ресурсозбереження, підвищення дохідності функціонування своїх складників, синергетичних ефектів від туристичної діяльності. Характерними ознаками кластерів у галузі туризму є, насамперед, чітко виражена спеціалізація, спільне взаємовигідне використання ресурсів та ринків, компактність розміщення, використання інновацій як умови створення, добровільність утворення суб’єктами господарювання [4, с. 206].

При цьому інновації у кластерах можуть мати місце як в обгрунтуванні нових конкурентоспроможних туристичних продуктів та послуг, так i при набутті конкурентних переваг, технологіях та механізмах здійснення туристичної діяльності, управлінні нею. Особливе значення у вдосконаленні структури туристичної галузі кластери мають у регіонах із значним туристично-рекреаційним потенціалом та наявністю значних резервів у розвитку галузі. Визначено, що найбільш поширеними є кластери, які утворюються навколо комплексоутворювального ядра або центру з метою спільної експлуатації його конкурентних переваг. Їх прикладами є відомі курорти або туристичні центри (Бердянськ, Буковель, Моршин), природні або культурно-історичні атракції (мінеральні води, грязі, морські та лісові ресурси, о. Хортиця, архітектурні комплекси міст, замків тощо).

Як підсумок визначення ефективності туристичного кластеру слід запропонувати оцінювання показника доходу від продажу продукції туристичної галузі окремим регіональним кластером, зокрема від туристичної ренти (монопольної, диференціальної, абсолютної, квазіренти, споживчої ренти, екологічної антиренти), який визначають як:

$$
X_{i j}=S_{i}\left(1 / n-\mathrm{b}_{i j}\left(p_{i j}-p\right)\right),
$$

де $X_{i j}$ - доход від продажу послуг $(i)$ туристичного кластера $(j) ; S_{i}$ - продажі послуг $(i)$ загалом у країні (у регіоні, у дестинації); $n-$ кількість підприємств туристичної сфери, що надають ці послуги; $b_{i j}$ - змінна попиту, який вказує на залежність ринкової частки туристичного кластера від ціни на його послуги; $p_{i j}-$ ціна послуг певного кластера; $p$ - середня ціна конкуруючих аналогічних послуг в інших регіональних (міжнародних) туристичних кластерах.

Пошук адекватних, швидкозмінних способів організації туристичного виробництва та економічної взаємодії спрямований на оптимізацію використання матеріальних і нематеріальних ресурсів, підвищення ефективності виробництва та збільшенню конкурентоспроможності на внутрішньому та зовнішніх ринках є пріоритетним завданням управлінських інновацій. У зв'язку з цим однією з головних складових успішного кластера $€$ його інноваційна спрямованість, оскільки без ïx впровадження кластерне об'єднання буде прототипом територіально-виробничих об’єднань i зможе проіснувати лише обмежений проміжок часу до логічного завершення свого виробничого потенціалу.

Обгрунтовано, що їх склад доцільно доповнювати альтернативними видами туристичної діяльності та супутніх послуг. Наприклад, традиційний курортно-лікувальний відпочинок у БердянськоПриморському туристичному кластері доцільно доповнити функціонуванням агросадиб та ферм i на їх основі - послугами сільського зеленого туризму, органічного землеробства та садівництва. Це сприяло б урізноманітненню туристичної діяльності, підвищенню ефективності розвитку галузі та результативності відпочинку для споживачів, раціональному використанню наявних у Запорізькій області туристично-рекреаційних ресурсів. Такі самі пропозиції стосуються Хортицького туристично-екскурсійного кластера. До його складу можна також включити заклади приморського туризму, лікування та оздоровлення. 
На основі розміщення та експлуатації туристично-рекреаційних ресурсів урочища Кам'яна могила, райцентрів області також доцільно утворити туристично-рекреаційні кластери зі спеціалізацією на відпочинковому, культурно-пізнавальному, релігійному, сільському, зеленому та ностальгійному туризмі. При цьому важливо вказати, що до складу кластерів, крім туристичних, входять агросадиби, сільськогосподарські, транспортні підприємства, заклади громадського харчування, соціально-культурні установи, де розміщені або які самі є туристичними атракціями. Їх кількість обмежується тіснотою наявних зв'язків, обсягами матеріально-ресурсних та грошових потоків, радіусом розміщення. Розрахунок останнього доцільно здійснювати на основі відповідного програмного забезпечення [4, c. 168].

Інноваційний характер туристичним регіональним кластерам надають нові туристичні бренди, послуги на умовах франшизи, соціальні інновації у вигляді інтеграційних об'єднань об'єктів туризму 3 метою збільшення сукупності надаваних послуг та розваг. Доцільно розвивати державно-приватне партнерство з метою удосконалення регіональної структури та підвищення ефективності розвитку галузі на основі бюджетної підтримки пріоритетних науково обгрунтованих бізнес-планів та інноваційно-інвестиційних проєктів. Інноваційні розробки стосуються також інформаційного забезпечення туристичної діяльності, поширення реклами в мережі Інтернет, навчання та підвищення кваліфікації кадрів на інноваційних засадах.

Висновки. 3 метою створення сприятливих умов розвитку туристичних кластерів вважаємо за необхідне реалізацію комплексу заходів на рівні національної економіки: розроблення й удосконалення законодавства 3 питань створення та регулювання діяльності кластерів в Україні; інформування потенційних учасників про переваги туристичних кластерів; державна підтримка розвитку туристичних кластерів, зниження адміністративних бар'єрів; підвищення ефективності системи навчання і підготовки спеціалістів у сфері туризму та готельно-ресторанної справи.
Таким чином, кластерна модель регіонального розвитку активізує підприємницьку діяльність у сфері туризму, сприяє створенню нових робочих місць, зростанню доходів місцевого населення та наповненню бюджетів, покращенню якості туристичних продуктів тощо. Функціонування туристичних кластерів сприяе ширшому використанню інноваційних та інформаційно-комунікаційних технологій, підвищенню рівня кваліфікації й інтелектуального потенціалу кадрів, зайнятих у туристичній галузі.

\section{Література}

1. Михайліченко Г. І. Формування інноваційних туристичних кластерів як конкурентної переваги розвитку регіону. Менеджмент та підприємництво в Україні: етапи становлення і проблеми розвитку. 2012. С. 341-349.

2. Michael E. Tourism micro-clusters. Tourism Economics, 9 (2), 133-145, 2013.

3. Jackson J., Murphy P. Clusters in regional tourism. An Australian case. Annals of Tourism Research, 4 (33), 1018-1035, 2016.

4. Марченко О. А. Трансформації та удосконалення регіональної структури туристичної галузі : монографія. Херсон : Айлант. 2014. 344 с.

\section{References}

1. Mykhaylichenko, H. I. (2012). Formuvannya innovatsiynykh turystychnykh klasteriv yak konkurentnoyi perevahy rozvytku rehionu [Formation of innovative tourist cluster as a competitive advantage of the development of the region]. Menedzhment ta pidpryyemnytstvo $v$ Ukrayini: etapy stanovlennya $i$ problemy rozvytku, 341-349 [in Ukr.].

2. Michael, E. (2013). Tourism micro-clusters. Tourism Economics, 9 (2), 133-145.

3. Jackson, J. \& Murphy, P. (2016). Clusters in regional tourism. An Australian case. Annals of Tourism Research, 4 (33), 1018-1035.

4. Marchenko, O. A. (2014). Transformatsiyi ta udoskonalennya rehionalnoyi struktury turystychnoyi haluzi [Transformation and improvement of the regional structure of the tourism industry]. Kherson, Ayalant [in Ukr.]. 


\section{Г. І. Фролова, Д. В. Василатій, Д. О. Миргородська}

\section{СТРАТЕГІЧНЕ ПЛАНУВАННЯ В УПРАВЛІННІ ЕКОНОМІЧНИМ РОЗВИТКОМ РЕГІОНУ}

Анотація. У статті розкрито особливості стратегічного управління економічним розвитком регіону. Аргументовано вплив внутрішніх і зовнішніх факторів на процес стратегічного планування. Визначено особливості стратегічного планування для забезпечення ефективного розвитку міста Бердянська в період 2017-2020 pp.

Ключові слова: регіон, стратегічне управління, економічний розвиток регіону, особливості організації стратегічного управління, стратегія розвитку, стратегічне планування розвитку міста, місія міста, стратегічні й операційні цілі розвитку міста.

Summary. The article describes the features of strategic management of economic development of the region. The influence of internal and external factors on the strategic planning process is argued. The features of strategic planning for ensuring the effective development of the city of Berdyansk in the period 2017-2020 are determined.

Key words: region, strategic management; economic development of the region; peculiarities of organization of strategic management; development strategy; strategic planning of city development; city mission; strategic and operational goals of the city development.

$$
\text { DOI : 10.33783/1977-4167-2019-46-2-116-125 }
$$

Постановка проблеми. Як відомозтеоретичних досліджень і практики розвитку багатьох країн світу та їх об'єднань, ефективнадержавна регіональна політика є одним із головних інструментів державної політики загалом, спрямованої як на посилення конкурентоспроможності економіки, підвищення якості та рівня життя людей і громад, так і на єдність та інтегрованість регіональних просторів держави, що особливо важливо в період зовнішньої агресії і кризи. На відміну від галузевих політик, державна регіональна політика повинна орієнтуватись, передусім, на просторовий ефект і синергію від певних політичних дій і заходів, стратегічного і просторового планування, використання різних фінансових та інвестиційно-інноваційних механізмів розвитку територій тощо.

Проведення в країні економічних перетворень привело до зростання ролі регіонів у всіх сферах життя суспільства. При цьому їх функціонування зумовлює необхідність формування ефективної системи управління, здатної реалізовувати економічну політику в умовах ринку. Адже нині для України стратегія економічного розвитку економіки регіонів $є$ головним завданням їх розвитку. Саме тому доцільним є визначення стра-

тегічних пріоритетів регіональних суб'єктів господарювання для забезпечення сталого розвитку країни, скорочення їх асиметрій і міжрегіональних диференціацій. 3 цією метою здійснюється розроблення систем стратегічного управління регіональним економічним розвитком.

Аналіз останніх досліджень і публікацій. Проблеми розроблення стратегії економічного розвитку регіонів досліджували вчені: Я. Жаліло, Д. Покришка, Я. Белінська, С. Богуславська, П. Пуцентейло, Л. Рогатіна, К. Меддок, О. Мрінська, А. Ткачук, Ю. Третяк, О. Панухник, Г. Жаворонкова та ін. Проте нині залишаються питання, котрі потребують подальших досліджень щодо теоретичного, методологічного і практичного їх вирішення.

Мета статті - проаналізувати напрями стратегічного управління та визначити роль стратегічного планування в управлінні економічним розвитком регіону.

Виклад основного матеріалу дослідження. Сучасне стратегічне управління стає поштовхом у формуванні, запровадженні та реалізації стратегії розвитку регіону на основі безперервного моніторингу та аналізу змін навколишнього середовища, що застосовується з метою підтримки регіону та

(ㄷ Г. І. Фролова, Д. В. Василатій, Д. О. Миргородська, 2019

Бібліографія ДСТУ 8302:2015:

Фролова Г. І., Василатій Д. В., Миргородська Д. О. Стратегічне планування в управлінні економічним розвитком регіону. Вісник Бердянського університету менеджменту і бізнесу. 2019. № 2 (46). С. 116-125.

References (APA):

Frolova, H. I., Vasylatii, D. V., Myrhorodska, D. O. (2019). Stratehichne planuvannia v upravlinni ekonomichnym rozvytkom rehionu [Strategic planning in management economic development of the region]. Visnyk Berdianskoho universytetu menedzhmentu i biznesu, 2 (46), 116-125 (in Ukr.). 
забезпечення його протекцією на державному рівні. Стратегічне управління є визнаним у світовій практиці елементом у системі регіонального управління та регулювання, що дозволяє створювати умови для перспективного розвитку та приймати поточні рішення з урахуванням стратегічних цілей. Реалізація стратегії можлива при спільному впливі всієї сукупності управлінських рішень і реалізації поетапних дій, виконуваних різними цільовими групами та окремими особами [1, с. 6]. Стратегія соціально-економічного розвитку регіону реально здійсненна тільки як невід’ємна узгоджена частина стратегії соціально-економічного розвитку країни та економічного району. Водночас вона набу- ває змісту і значення як інтеграційна індикативна стратегія для мікроекономічних одиниць самого регіону і спрямовує інші суб'єкти господарювання різного масштабу із зовнішнього середовища (ТНК, інтеграційні союзи й альянси, міжнародні організації тощо) [2, с. 569].

Сутність стратегічного управління полягає у реалізації довгострокових планів, що відображають кінцевий результат та шляхи його досягнення, передбачає створення та розвиток певної економічної моделі, яка залежить від зовнішніх і внутрішніх факторів.

На розвиток регіонів впливають як внутрішні, так і зовнішні фактори (табл. 1).

Таблиия

Перелік та характеристика внутрішніх (ендогенних) та зовнішніх (екзогенних) факторів розвитку регіону [3]

\begin{tabular}{|c|c|}
\hline Фактор & Характеристика \\
\hline \multicolumn{2}{|r|}{ Ендогенні фактори } \\
\hline $\begin{array}{l}\text { Природно-ресурсний } \\
\text { потенціал }\end{array}$ & $\begin{array}{l}\text { Характеризується станом і прогнозними оцінками земельних, водних, лісових, мі- } \\
\text { нерально-сировинних, оздоровчих і рекреаційних ресурсів та станом природного } \\
\text { середовища }\end{array}$ \\
\hline $\begin{array}{l}\text { Оцінювання земельних } \\
\text { ресурсів }\end{array}$ & $\begin{array}{l}\text { Здійснюється на основі визначення рівня та ефективності використання земель- } \\
\text { них ресурсів за даними земельного кадастру (форма 6-зем.); рівня господарського } \\
\text { використання, розподілу земельного фонду за власниками і землекористувачами, } \\
\text { за категоріями земель; рівня забудови земель населених пунктів, промисловості, } \\
\text { транспорту, зв’язку, частки земель екологічної мережі; грошової оцінки земель, } \\
\text { можливості й умов функціонального перерозподілу земель. Наводяться дані про } \\
\text { якісний стан та рівень біопродуктивності земельних угідь та ефективність їх ви- } \\
\text { користання }\end{array}$ \\
\hline Оцінювання водних ресурсів & $\begin{array}{l}\text { Проводиться шляхом визначення їх обсягів, якісного стану, можливостей збіль- } \\
\text { шення, ступеня та ефективності використання }\end{array}$ \\
\hline Лісові ресурси & $\begin{array}{l}\text { Оцінюються за площею, породним складом, віковою структурою, категоріями за- } \\
\text { хищеності, продуктивністю та використанням лісового фонду }\end{array}$ \\
\hline $\begin{array}{l}\text { Мінерально-сировинні ре- } \\
\text { сурси (включно з так звани- } \\
\text { ми «техногенними родови- } \\
\text { щами») }\end{array}$ & $\begin{array}{l}\text { Оцінюються за їх структурою, запасами та можливостями їх приросту, об’ємами та } \\
\text { умовами видобутку }\end{array}$ \\
\hline Економічний потенціал & $\begin{array}{l}\text { Оцінюється за обсягами, структурою, рівнем використання, ступенем зношеності } \\
\text { основних фондів, розгалуженістю виробничої бази, часткою наукоємних інвести- } \\
\text { ційно-спроможних галузей і підприємств, здатних до реалізації інноваційної моделі } \\
\text { економічного зростання, ступенем кваліфікації трудових ресурсів, потужністю, } \\
\text { технічним станом та щільністю інженерно-транспортної інфраструктури }\end{array}$ \\
\hline $\begin{array}{l}\text { Оцінювання науково-техніч- } \\
\text { ного потенціалу }\end{array}$ & $\begin{array}{l}\text { Здійснюється за показниками наявності науково-дослідних, дослідно-експеримен- } \\
\text { тальних, упроваджуючих, інформаційних, проєктних організацій, вищих навчаль- } \\
\text { них закладів, їх відповідності спеціалізації економіки регіону, кількісної та якісної } \\
\text { характеристики наукових кадрів, наявності наукових розробок світового рівня, } \\
\text { кількості отриманих патентів }\end{array}$ \\
\hline $\begin{array}{l}\text { Стан оточуючого природного } \\
\text { середовища }\end{array}$ & $\begin{array}{l}\text { Характеризується рівнями забруднення водного та повітряного басейнів, грунтів, } \\
\text { обсягами накопичення всіх видів від доходів та їх видовою структурою, акустичного } \\
\text { дискомфорту, електричних і магнітних полів, випромінювання й опромінювання, } \\
\text { потужністю, структурою та перспективами нарощування елементів екологічної ме- } \\
\text { режі (заповідники, національні природні парки, біосферні заповідники, заказни- } \\
\text { ки, екологічні коридори тощо) }\end{array}$ \\
\hline $\begin{array}{l}\text { Оцінювання трудового по- } \\
\text { тенціалу }\end{array}$ & $\begin{array}{l}\text { Включає визначення існуючої та прогнозованої кількості та вікової структури тру- } \\
\text { дових ресурсів, їх кваліфікації, зайнятості та стану на ринку праці (кількість та рі- } \\
\text { вень безробіття тощо) }\end{array}$ \\
\hline
\end{tabular}


Продовження табл. 1

\begin{tabular}{|c|c|}
\hline Фактор & Характеристика \\
\hline Туристичний потенціал & $\begin{array}{l}\text { Оцінюється за наявністю, кількісною та якісною характеристикою історико-куль- } \\
\text { турних (історична спадщина), природно-кліматичних та медико-санітарних умов, } \\
\text { лікувально-оздоровчих, рекреаційних ресурсів, розвитком туристичної інфра- } \\
\text { структури }\end{array}$ \\
\hline $\begin{array}{l}\text { Рівень природно-технічної } \\
\text { безпеки }\end{array}$ & $\begin{array}{l}\text { Характеризується переліком, структурою, розміщенням потенційно небезпечних } \\
\text { об’єктів та інших джерел виникнення надзвичайних ситуацій, їх розподілом за гру- } \\
\text { пами ризику, параметри зон уражень (площа території, кількість населених пунктів } \\
\text { та населення) та наслідками надзвичайних ситуацій, станом об’єктів, переліком, } \\
\text { вартістю та джерелами фінансування запобіжних заходів }\end{array}$ \\
\hline $\begin{array}{l}\text { Оцінювання просторово-еко- } \\
\text { номічного потенціалу (опо- } \\
\text { рного каркасу територіі) }\end{array}$ & $\begin{array}{l}\text { 3дійснюється шляхом виявлення основних ліній та вузлів соціально-економічного } \\
\text { розвитку і тяжіння інвестицій; існуючих чи намічуваних міжнародних транспорт- } \\
\text { них коридорів, інших інфраструктурно-комунікаційних магістралей, головних } \\
\text { річок, узбережжя морів, прикордонних смуг та розташованих на їх перетинанні } \\
\text { головних міст, а також зон їх стимулюючого впливу }\end{array}$ \\
\hline \multicolumn{2}{|r|}{ Екзогенні фактори } \\
\hline $\begin{array}{l}\text { Імовірність геоекономічного } \\
\text { та геополітичного положення } \\
\text { регіону в системі прилеглих } \\
\text { регіонів або країн }\end{array}$ & $\begin{array}{l}\text { Визначається наявністю мережі міжнародних транспортних коридорів, загально- } \\
\text { державних та міжрегіональних комунікаційних магістралей тощо }\end{array}$ \\
\hline $\begin{array}{l}\text { Вплив (реальний та прогно- } \\
\text { зований) макроекономічної } \\
\text { ситуації }\end{array}$ & $\begin{array}{l}\text { Оцінюється за результатами розвитку економіки країни, кон'юнктури внутрішньо- } \\
\text { го ринку, соціально-політичної стабільності в державі тощо }\end{array}$ \\
\hline $\begin{array}{l}\text { Вплив (реальний та прогно- } \\
\text { зований) зовнішньоеконо- } \\
\text { мічної та зовнішньополітич- } \\
\text { ної ситуації }\end{array}$ & $\begin{array}{l}\text { Оцінюється на основі здійснення якісної та кількісної характеристики зовнішніх } \\
\text { відносин, міжрегіональних та зовнішньоекономічних зв'язків (у тому числі участь у } \\
\text { транскордонному та міжрегіональному співробітництві), оцінки кон'юнктури світо- } \\
\text { вого ринку, зовнішньополітичної ситуації в країнах, що є основними діловими парт- } \\
\text { нерами тощо }\end{array}$ \\
\hline
\end{tabular}

Стратегічне управління необхідно розглядати як управлінську діяльність, спрямовану на досягнення поставлених цілей в умовах нестабільного, конкурентного ринкового середовища. У контурі стратегічного управління розглядаються завдання конструювання системи, здійснюється структурна адаптація керованої системи до зовнішніх і внутрішніх змін економічного середовища.

У контурі поточного управління суб'єКТ управління діє в рамках побудованої системи i, відповідно, ним вирішуються завдання вибору і коригування значень керованих параметрів діючої системи, тобто вирішується завдання параметричної адаптації.

Стратегія регіону як план - це певне керівництво розвитку економіки області, вектор роботи владних структур для здійснення поставлених цілей регіонального розвитку.

Таким чином, поняття «стратегічне управління» - це управління відповідно до обраної стратегії розвитку. Суб'єктом управління виступають місцеві органи влади, котрі визначають розвиток регіону у взаємозв'язку із загальною національною стратегією розвитку. Система стратегічного управління дає змогу ефективно управляти економікою в умовах невизначеності зовнішніх і внутрішніх чинників і параметрів економічного розвитку. Стратегія визначає напрями майбутнього розвитку регіону, яким місцева громада буде слідувати в довгостроковій перспективі, закладає основу для розроблення програм економічного розвитку території, цільових програм і проєктів, пов'язаних 3 реалізацією стратегії, вирішенням питань локального характеру, розвитком територіальних спільнот базового рівня. Сутнісна специфіка стратегічного управління, на відміну від інших методів управління економічним розвитком регіону, полягає в прийнятті та реалізації управлінських рішень на основі розроблення і офіційної легітимізації стратегії розвитку регіону. Для регіону стратегія його довгострокового розвитку - це інструмент цілеспрямованого впливу регіональних органів влади на основних суб'єктів території з метою підвищення якості життя місцевої громади та конкурентоспроможності регіону [4].

Система стратегічного планування регіонального розвитку в Україні представлена стратегічними та програмними документами чотирьох рівнів: державного, регіонального, субрегіонального та базового.

На загальнодержавному рівні стратегічні пріоритети розвитку для всіх регіонів України визначені в Державній стратегій регіонального розвитку на період до 2020 р., яка визначає три основні цілі: підвищення рівня конкурентоспроможності регіонів, територіальна соціально-економічна інтеграція і просторовий розвиток та ефективне державне управління у сфері регіонального розвитку [5]. 
Важливою формою реалізації зазначених аспектів регіонального розвитку є стратегічне планування, яке дає можливість впровадити ефективне управління регіоном як єдиним організмом та забезпечити належний рівень життя його населення. Тому необхідно приділяти увагу стратегічному плануванню, що є природним для етапу становлення місцевого самоврядування, спричинених кризою системи централізованого управління, відмовою від прямого регулювання економіки, реформуванням ієрархічних відносин, наслідком чого є підвищення рівня самостійності та відповідальності органів місцевого самоврядування [6].

Стратегічне планування регіонального розвитку в Україні було запроваджено Законом України «Про стимулювання розвитку регіонів» [7].

Для забезпечення ефективного розвитку міста Бердянська впродовж останніх двадцяти років тричі застосовувалися процеси стратегічного планування розвитку міста. Останнім була Стратегія розвитку міста на період до 2017 р. Щорічно членами робочого Комітету з управління реалізацією стратегії проводився моніторинг виконання стратегіі. Оскільки термін впровадження стратегії добігав кінця, міською радою було прийнято рішення розпочати роботу з формування нового документа з урахуванням зовнішніх та внутрішніх змін у житті міста.

Для розроблення Стратегіі, з метою визначення пріоритетних напрямів до 2027 р., ефективного використання фінансових, матеріальних та людських ресурсів, відповідності довгостроковим інтересам громади в частині опрацювання пропозицій щодо вирішення питань соціально-економічного та культурного розвитку міста Бердянська було створене партнерство, що передбачало участь органу місцевого самоврядування, освітніх установ, організацій громадянського суспільства, представників приватного сектору та інших зацікавлених сторін громади. Партнером підготовки Стратегії виступив проєкт «Партнерство для розвитку міст» (Проєкт ПРОМІС), який реалізується федерацією канадських муніципалітетів за фінансової підтримки Уряду Канади, що діяв переважно як технічна допомога, надаючи методичні рекомендації в процесі розроблення Стратегії.

Головними висновками з процесу Стратегічного планування є:

1. Стратегія є потужним інструментом об'єднання лідерів бізнесу, посадовців місцевої влади, пересічних громадян для створення публічноприватного партнерства, що має позитивний вплив на місцевий діловий клімат та конкурентне становище громади, а також на вирішення інших питань, пов'язаних з рівнем життя всіх громадян.

2. Стратегія підкреслює конкурентні переваги території громади на підставі існуючих при- родних, матеріальних, фінансових, економічних, трудових, соціальних, інтелектуальних ресурсів, які при належній організації та об’єднанні зусиль можна використовувати для вирішення нагальних проблем місцевого економічного розвитку. Тому Стратегія зосереджена на напрямах, які нададуть економічному розвитку території найбільші шанси в майбутньому. Економічний розвиток передбачає формування сприятливого бізнес-середовища, створення умов для інвестування на тривалий період, що сприятиме економічному зростанню та поліпшенню якості життя громади.

3. Залучення інвестицій, розвиток місцевих підприємств, поліпшення інфраструктури й забезпечення гідної якості життя є взаємопов'язаними сферами. Тому успішна робота над ними можлива лише за умови сприйняття їх як цілісної системи. Поліпшення в одній зі сфер сприятиме поліпшенню в інших.

4. Стратегія пов'язана з іншими документами стратегічного характеру, місцевими та регіональними програмами, які вже ухвалені і виконуються відповідними органами.

Робочою комісією з розроблення Стратегії розвитку м. Бердянська, групи експертів Проєкту ПРОМІС. 3 урахуванням результатів опитування мешканців міста відбулося ухвалення формулювання Місії та стратегічного бачення розвитку міста, узгодження результатів СВОТаналізу за напрямами розвитку, визначення переліку стратегічних, оперативних цілей і завдань за кожним з напрямів розвитку міста. Робоча комісія працювала підгрупами та провела обговорення варіанта напрацьованих чотирьох стратегічних напрямів, а саме: розвиток туризму; розвиток бізнесу та залучення інвестицій; розвиток інфраструктури та збереження довкілля; ефективне управління та активізація громади. Кожною підгрупою визначено перелік стратегічних, оперативних цілей та завдань.

Місія міста сформульована як «місто Бердянськ - «серце Азова»»: морський, кліматичний і грязьовий курорт державного значення, оздоровчий центр Північного Приазов'я з поліфункціональною економікою; провідний центр морської логістики Північного Приазов’я; культурне, гостинне місто з власним обличчям, що надає гостям і мешканцям море задоволень.

Стратегічні цілі випливають із стратегічного бачення та стратегічних напрямів розвитку і утворюють рамки, у яких прийматимуться рішення щодо конкретних цілей та заходів (рис. 1). Кожна стратегічна ціль конкретизується в оперативних цілях, що є конкретними, обмеженими у часі алгоритмами дій щодо досягнення стратегічних цілей. Сукупність оперативних цілей складає стратегічну ціль. Оперативні цілі показують, як 
необхідно проводити зміни та визначають стратегічні цілі кількісно, вказують терміни виконання, конкретних виконавців, результат виконання, обсяги та джерела фінансування, конкретні заходи. Кількість оперативних цілей має бути такою, щоб виконати стратегічну ціль (рис. 1).

Один із рекомендованих методологічних підходів до розроблення регіональної стратегії розвитку полягає в тому, щоб досягалась належна узгодженість пропонованих Стратегічних і Операційних цілей з аналогічними цілями Державної стратегії регіонального розвитку на період до 2020 р. [8].

Стратегія розвитку міста Бердянська на період до 2027 р. включає цілі, що відповідають цілям реалізації Державної стратегії регіонального розвитку України до 2020 р. (ДСРР-2020), особливо щодо завдань і заходів, які передбачають спільні дії центральних, регіональних і місцевих органів виконавчої влади, органів місцевого самовряду- вання. Ключовою основою зрушень у розвитку міста Бердянська є зміна підходів щодо управління процесами, що є основою впровадження ДСРР-2020 (табл. 2).

Стратегія розвитку міста Бердянська на період до 2027 р. включає стратегічні напрями та цілі, що цілком відповідають цілям Стратегії розвитку Запорізької області до 2020 р. Значну увагу приділено узгодженості тих завдань і заходів, які спрямовані на пришвидшення місцевого й регіонального розвитку, а також передбачають спільні дії регіональних органів влади та органів місцевого самоврядування (табл. 3).

Реалізація Стратегії здійснюватиметься в режимі проєктного управління, з планом реалізації на найближчі три роки, а для досягнення кожної оперативної цілі підготовлено проєктну картку, яка містить короткий виклад способу досягнення запланованого результату.

\begin{tabular}{|c|c|c|c|}
\hline \multicolumn{4}{|c|}{ СТРАТЕГІЧНЕ БАЧЕННЯ РОЗВИТКУ МІСТА БЕРДЯНСЫКА 2027: } \\
\hline \multicolumn{4}{|c|}{$\begin{array}{ll}\text { - } & \text { курорт високого рівня оздоровчих послуг і сімейного відпочинку, } \\
\text { - } & \text { інвестиційно привабливий центр конкурентоспроможного бізнесу й морської логістики, } \\
\text { - } & \text { екологічно безпечне місто, комфортне для життя та різноманітного здорового дозвілля, } \\
\text { - } & \text { місто якісних і доступних послуг з ефективною системою управління та можливостями самореалізації гро- } \\
\text { мадян } & \end{array}$} \\
\hline \multicolumn{4}{|c|}{ НАПРЯМИ РОЗВИТКУ МІСТА } \\
\hline $\begin{array}{c}\text { А.РОЗВИТОК } \\
\text { СФЕРИ } \\
\text { ОЗДОРОВЛЕННЯ } \\
\text { ТА ТУРИЗМУ }\end{array}$ & $\begin{array}{l}\text { В.РОЗВИТОК } \\
\text { БІЗНЕСУ ТА } \\
\text { ЗАЛУЧЕННЯ } \\
\text { ІНВЕСТИЦІЙ }\end{array}$ & $\begin{array}{c}\text { С.РОЗВИТОК } \\
\text { ІНФРАСТРУКТУРИ } \\
\text { ТА ЗБЕРЕЖЕННЯ } \\
\text { ДОВКІЛЛЯ }\end{array}$ & $\begin{array}{c}\text { D.ЕФЕКТИВНЕ } \\
\text { УПРАВЛІННЯ ТА } \\
\text { АКТИВІЗАЦІЯ } \\
\text { ГРОМАДИ }\end{array}$ \\
\hline \multicolumn{4}{|c|}{ СТРАТЕГІЧНІ ЦІЛІ } \\
\hline $\begin{array}{c}\text { А.1. Підвищення } \\
\text { якості надання } \\
\text { туристичних послуг }\end{array}$ & $\begin{array}{c}\text { В.1. Створення } \\
\text { інвестиційних продуктів } \\
\text { та інструментів }\end{array}$ & $\begin{array}{c}\text { C.1. Поліпшення стану } \\
\text { довкілля }\end{array}$ & $\begin{array}{c}\text { 1. Надання якісних } \\
\text { послуг у сфері освіти } \\
\text { та культури }\end{array}$ \\
\hline \multirow[t]{3}{*}{$\begin{array}{l}\text { А.2. Маркетинг і } \\
\text { брендинг міста }\end{array}$} & $\begin{array}{l}\text { В.2. Підтримка малого } \\
\text { та середнього } \\
\text { підприємництва }\end{array}$ & $\begin{array}{c}\text { С.2. Формування } \\
\text { зручної транспортної } \\
\text { системи міста }\end{array}$ & $\begin{array}{c}\text { 2. Покращення } \\
\text { стану здоров’я } \\
\text { населення міста }\end{array}$ \\
\hline & & $\begin{array}{c}\text { С.з. Системне } \\
\text { запровадження } \\
\text { заходів } 3 \\
\text { енергозбереження }\end{array}$ & $\begin{array}{c}\text { 3. Впровадження } \\
\text { якісних доступних } \\
\text { адміністративних } \\
\text { послуг }\end{array}$ \\
\hline & & & $\begin{array}{c}\text { 4. Створення } \\
\text { довірливих відносин } \\
\text { у громаді через } \\
\text { ефективну } \\
\text { комунікацію «бізнес- } \\
\text { влада-громада» }\end{array}$ \\
\hline
\end{tabular}

Рис. 1. Визначення стратегічних цілей розвитку м. Бердянська [8] 
Таблиия 2

Узгодженість стратегічних цілей Стратегії розвитку міста Бердянська з цілями Державної стратегії регіонального розвитку на період до 2020 р. [10]

\begin{tabular}{|c|c|c|c|c|c|c|c|c|c|c|c|}
\hline \multirow[b]{2}{*}{$\begin{array}{c}\text { Цілі Державної стратегії регіонального } \\
\text { розвитку на період до } 2020 \text { року }\end{array}$} & \multicolumn{11}{|c|}{$\begin{array}{l}\text { Стратегічні цілі Стратегії розвитку міста Бердянська на період } \\
\text { до } 2027 \text { р. }\end{array}$} \\
\hline & 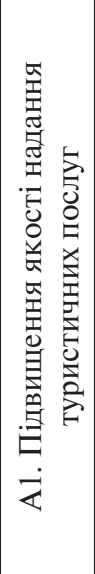 & 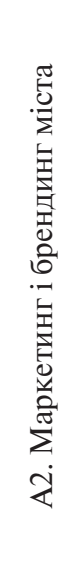 & 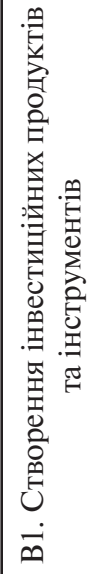 & 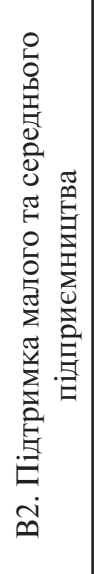 & 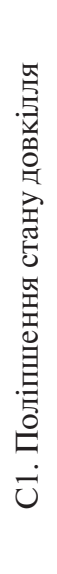 & 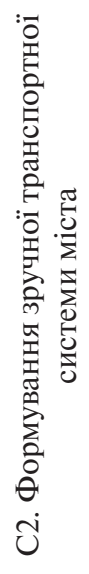 & 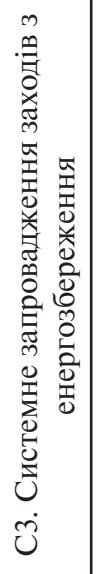 & 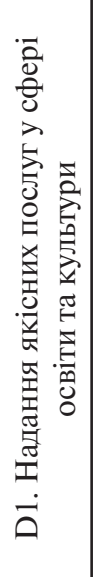 & 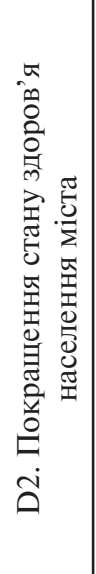 & 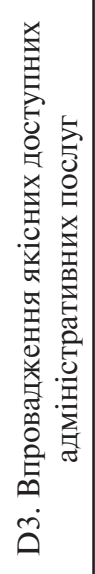 & 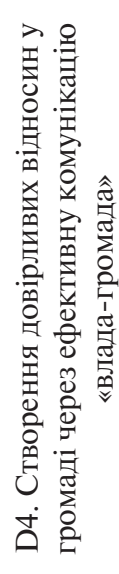 \\
\hline $\begin{array}{l}\text { 1.1. Підвищення ролі та функціо- } \\
\text { нальних можливостей міст у подаль- } \\
\text { шому розвитку регіонів }\end{array}$ & $X$ & $X$ & $X$ & $X$ & & & & & & & \\
\hline $\begin{array}{l}\text { 1.2. Створення умов для поширення } \\
\text { позитивних процесів розвитку міст } \\
\text { на інші території, розвиток сільської } \\
\text { місцевості }\end{array}$ & & & $X$ & $X$ & & & & & & & \\
\hline $\begin{array}{l}\text { 1.3. Підвищення ефективності вико- } \\
\text { ристання внутрішніх чинників роз- } \\
\text { витку регіонів }\end{array}$ & $X$ & & & & & & & & & & \\
\hline $\begin{array}{l}\text { 2.1. Запобігання зростанню диспро- } \\
\text { порцій, що гальмують розвиток регі- } \\
\text { онів }\end{array}$ & & & & & & & & & & & \\
\hline $\begin{array}{l}\text { 2.2. Забезпечення комфортного та } \\
\text { безпечного життєвого середовища для } \\
\text { людини незалежно від місця ії прожи- } \\
\text { вання }\end{array}$ & & & & & $X$ & $X$ & $X$ & $X$ & $X$ & $X$ & $X$ \\
\hline $\begin{array}{l}\text { 2.3. Розвиток міжрегіонального спів- } \\
\text { робітництва }\end{array}$ & & & & & & & & & & & \\
\hline $\begin{array}{l}\text { 3.1. Удосконалення системи страте- } \\
\text { гічного планування регіонального } \\
\text { розвитку на загальнодержавному та } \\
\text { регіональному рівнях }\end{array}$ & & & & & & & & & & & \\
\hline $\begin{array}{l}\text { 3.2. Підвищення якості державного } \\
\text { управління регіональним розвитком }\end{array}$ & & & & & & & & & & $X$ & \\
\hline $\begin{array}{l}\text { 3.3. Посилення міжгалузевої коор- } \\
\text { динаціїв процесі планування та реа- } \\
\text { лізації регіональної політики }\end{array}$ & & & $X$ & & & & & & & & \\
\hline $\begin{array}{l}\text { 3.4. Інституційне забезпечення регі- } \\
\text { онального розвитку }\end{array}$ & & & & & & & & & & $X$ & \\
\hline $\begin{array}{l}\text { 3.5. Реформування територіальної } \\
\text { організації влади та місцевого само- } \\
\text { врядування }\end{array}$ & & & & & & & & & & $X$ & $X$ \\
\hline
\end{tabular}


Узгодженість стратегічних цілей Стратегії розвитку міста Бердянська з цілями Стратегії розвитку

Таблиия 3 Запорізької області до 2020 р. [11]

\begin{tabular}{|c|c|c|c|c|c|c|c|c|c|c|c|}
\hline \multirow{2}{*}{$\begin{array}{l}\text { Цілі Стратегії Запорізької області } \\
\text { на період до } 2020 \text { р. }\end{array}$} & \multicolumn{11}{|c|}{ Стратегічні цілі Стратегії розвитку міста Бердянська на період до 2027 р. } \\
\hline & 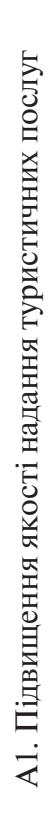 & 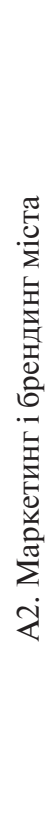 & 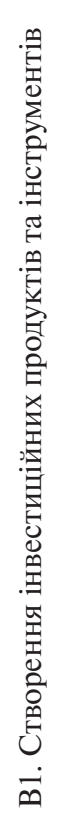 & 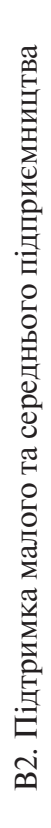 & 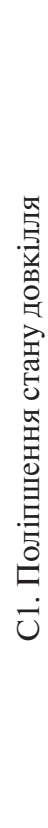 & 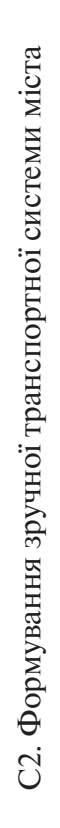 & 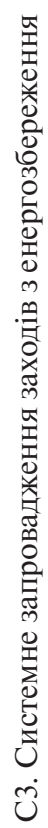 & 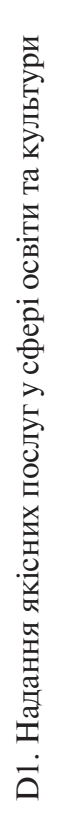 & 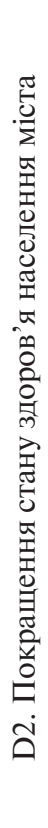 & 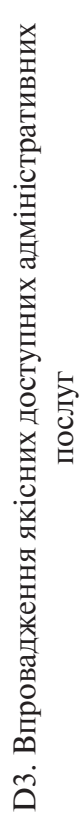 & 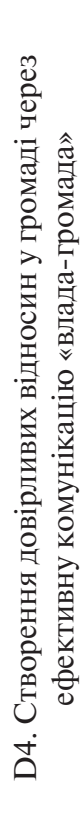 \\
\hline $\begin{array}{l}\text { 1.1. Стимулювання залучення } \\
\text { інвестицій }\end{array}$ & & & $\mathrm{X}$ & & & & & & & & \\
\hline $\begin{array}{l}\text { 1.2. Розвиток малого та середнього } \\
\text { підприємництва }\end{array}$ & & & & $\mathrm{X}$ & & & & & & & \\
\hline 1.3. Розвиток внутрішнього туризму & $\mathrm{X}$ & & & & & & & & & & \\
\hline $\begin{array}{l}\text { 2.1. Збільшення доданої вартості } \\
\text { сільськогосподарської продукції }\end{array}$ & & & & & & & & & & & \\
\hline $\begin{array}{l}\text { 2.2. Підтримка зайнятості сільсько- } \\
\text { го населення }\end{array}$ & & & & & & & & & & & \\
\hline $\begin{array}{l}\text { 2.3. Розвиток інфраструктури сіль- } \\
\text { ських територій }\end{array}$ & & & & & & & & & & & \\
\hline $\begin{array}{l}\text { 3.1. Підвищення адаптивності на- } \\
\text { селення до потреб ринку праці }\end{array}$ & & & $\mathrm{X}$ & $\mathrm{X}$ & & & & & & & \\
\hline $\begin{array}{l}\text { 3.2. Підвищення стану здоров’я } \\
\text { населення }\end{array}$ & & & & & & & & & $X$ & & \\
\hline $\begin{array}{l}\text { 4.1. Енергоефективність та під- } \\
\text { тримка альтернативної енергетики }\end{array}$ & & & & & & & $\mathrm{X}$ & & & & \\
\hline $\begin{array}{l}\text { 4.2. Створення умов для поліпшен- } \\
\text { ня стану довкілля }\end{array}$ & & & & & $\mathrm{X}$ & & & & & & $\mathrm{X}$ \\
\hline $\begin{array}{l}\text { 4.3. Розвиток екомережі та рекреа- } \\
\text { ційних зон }\end{array}$ & $\mathrm{X}$ & & & & & & & & & & \\
\hline
\end{tabular}


Для забезпечення моніторингу ефективності виконання Стратегії рекомендується створити багаторівневу ієрархічну модель системи індикаторів. Кожен рівень стратегічного планування має свій рівень індикаторів (показників), які розділяються на індикатори досягнення: бачення та напрямів розвитку; стратегічних цілей; оперативних цілей. На рівні бачення розвитку території, що фактично складається з стратегічних напрямів розвитку, визначаються показники вищого рівня. Показники розвитку за стратегічними цілями середній рівень, індикатори виконання проєктів та досягнення оперативних цілей - нижній рівень.

Систему контролю на різних етапах виконання власної Стратегії можна побудувати на основі розроблених форм контролю за досягненням стратегічних цілей та виконанням проєктів. Але одним із типів виявлених індикаторів є такі, збір яких передбачений державною системою статистики. Як правило, вони з'являються на рівні стратегічних цілей та напрямів розвитку. Це дає змогу унікальну систему індикаторів співставляти 3 державними та міжнародними системами.

У ході моніторингу виконання Стратегії вирішується низка завдань: контроль за реалізацією в цілому; оцінювання ступеня досягнення прогресу за стратегічними напрямами, стратегічними та оперативними цілями; аналіз інформації щодо змін зовнішніх і внутрішніх чинників розвитку громади для уточнення та коригування (актуалізації) цілей Стратегіï.

Після розроблення та затвердження Стратегія має стати місцевою нормативною базою формування річного бюджету міської ради та річної програми соціально-економічного розвитку громади міста.

Стратегія має коригуватися зважаючи на зовнішні та внутрішні обставини, які також будуть змінюватися. Принаймні один раз на три роки Комітет з управління впровадженням має забезпечити розроблення нового Плану реалізації Стратегії (проєктних карток до проєктів 3 алгоритмом їх виконання, зазначенням результатів, показників, відповідальних осіб і виконавців, строків та джерел ресурсів). Отже, члени Комітету з управління впровадженням, а також усі мешканці громади, які мають відношення до цієї роботи, повинні стежити за тим, щоб стратегічні й оперативні цілі та проєкти Стратегії залишалися доречними, актуальними та виконувалися [10].

Таким чином, особливістю стратегічного планування та реалізації стратегій соціально-економічного розвитку $є$ те, що в системі «національна економіка - макроструктурна галузь - область - місто - селище - село - підприємство» повинна простежуватися цілісність, стратегії соціально-економічного розвитку підсистем мікро-, мезо- та макрорівнів не повинні суперечити одна одній. Лише за умови взаємоузгодження розроблення і впровадження стратегічних планів на всіх ієрархічних рівнях можна забезпечити ефективність функціонування усієї системи стратегічного планування в контексті управління національним господарством. Зокрема в основу цієї системи повинен бути закладений комплексний методичний підхід як базис розробки та реалізації стратегій і стратегічних планів. Однак у вітчизняній практиці не на всіх рівнях національної економіки розроблено методичне забезпечення формування стратегій i стратегічних планів розвитку, методики, які використовуються в управлінській діяльності, містять низку недоліків з точки зору впливу на реалізацію стратегічного плану [11].

Висновки. 1. Стратегічне управління $є$ визнаним у світовій практиці елементом у системі регіонального управління та регулювання, що дозволяє створювати умови для перспективного розвитку та приймати поточні рішення з урахуванням стратегічних цілей.

2. Стратегія соціально-економічного розвитку регіону реально здійсненна тільки як невід'ємна узгоджена частина стратегії соціально-економічного розвитку країни та економічного району.

3. Сутність стратегічного управління полягає у реалізації довгострокових планів, що відображають кінцевий результат та шляхи його досягнення, передбачає створення та розвиток певної економічної моделі, яка залежить від зовнішніх і внутрішніх факторів.

4. Стратегія регіону як план - це певне керівництво розвитку економіки області, вектор роботи владних структур для здійснення поставлених цілей регіонального розвитку.

5. Система стратегічного планування регіонального розвитку в Україні представлена стратегічними та програмними документами чотирьох рівнів: державного, регіонального, субрегіонального та базового. На загальнодержавному рівні стратегічні пріоритети розвитку для всіх регіонів України визначені в Державній стратегії регіонального розвитку на період до 2020 р., яка визначає три основні цілі: підвищення рівня конкурентоспроможності регіонів, територіальна соціально-економічна інтеграція і просторовий розвиток та ефективне державне управління у сфері регіонального розвитку

6. Алгоритм розроблення Стратегії економічного розвитку міста Бердянська такий: організація роботи; проведення аналізу зовнішнього та внутрішнього середовища; визначення стратегічного бачення, напрямів розвитку; розро- 
блення планів дій / плану реалізації; громадське обговорення та ухвалення Стратегії; моніторинг та впровадження стратегічного плану економічного розвитку міста.

7. Особливістю стратегічного планування та реалізації стратегій соціально-економічного розвитку є те, що в системі «національна економіка - макроструктурна галузь - область місто - селище - село - підприємство» має простежуватися цілісність, стратегії соціальноекономічного розвитку підсистем мікро-, мезота макрорівнів не повинні суперечити одна одній.

\section{Література}

1. Жаліло Я. А., Покришка Д. С., Белінська Я. В. Післякризовий розвиток економіки України. Київ : НІСД, 2011. 66 с.

2. Богуславська С. І. Ключові елементи стратегічного управління розвитком регіональних соціально-економічних систем. Глобальні та національні проблеми економіки, 2016, 11, C. 565-570. URL : http://global-national.in.ua/ archive/11-2016/118.pdf.

3. Міністерство економіки та 3 питань Европейської інтеграції. Методичні рекомендації щодо формування регіональних стратегій розвитку. К., 2002. 15 с.

4. Пуцентейло П. Р. Особливості формування стратегії управління економічним розвитком регіону. Подільський вісник: сільське господарство, техніка, економіка. 2017. Вип. 27. C. 298-308. URL : http://188.190.33.56:7980/jspui/ bitstream/123456789/2458/1/PB-27-298-308.pdf.

5. Державна Стратегія регіонального розвитку України на період до 2020 року. URL : http:// www.csi.org.ua/www/wp-content/uploads/2013/05/ nsrdu2020_1.pdf.

6. Жаворонкова Г. В., Жаворонков В. А. Стратегічне управління розвитком регіону. Проблеми екологічної біотехнології. 2010. № 1. С. 26-31.

7. Про стимулювання розвитку регіонів : Закон України від 02.12.2012 р. № 2850-IV. URL : http://zakon.rada.gov.ua/laws/show/2850-15.

8. Стратегія розвитку м. Бердянська на період до 2027 року. URL : http://pleddg.org.ua/wpcontent/uploads/2018/09/Strategiya-Berdyansk. pdf.

9. Меддок К., Мрінська О., Ткачук А., Третяк Ю. Регіональний розвиток та державна регіональна політика в Україні: стан і перспективи змін у контексті глобальних викликів та європейських стандартів політики. Аналітичний звіт. К. : Проект $Є С$ «Підтримка політики регіонального розвитку в Україні», 2014. 452 с.

10. Стратегія розвитку м. Бердянська на період до 2027 року. URL : http://pleddg.org.ua/wpcontent/uploads/2018/09/Strategiya-Berdyansk.pdf.
11. Панухник О. В. Методичне забезпечення стратегічного планування в регіонах України. Актуальні проблеми економіки. 2011. № 1 (91). С. 152-157.

\section{References}

1. Zhalilo, Ya., Pokryskhina, D., Belinskaya, Ya. (2011). Pisliakryzovyi rozvytok ekonomiky Ukrainy [Post-crisis development of the Ukrainian economy]. Kyiv, NISD (in Ukr.).

2. Boguslavskaya, S. (2016). Kliuchovi elementy stratehichnoho upravlinnia rozvytkom rehionalnykh sotsialnoekonomichnykh system [Key elements of strategic management of the development of regional socioeconomic systems]. Hlobalni ta natsionalni problemy ekonomiky, 11, 565-570. Retrieved from http://globalnational.in.ua/archive/11-2016/118.pdf (in Ukr.).

3. Ministry of Economics and European Integration (2002). Metodychni rekomendatsii shchodo formuvannia rehionalnykh stratehii rozvytku [Methodical recommendations on the formation of regional development strategies]. Kyiv (in Ukr.).

4. Putsenteylo, P. (2017). Osoblyvostiformuvannia stratehii upravlinnia ekonomichnym rozvytkom rehionu [Features of the formation of a strategy for managing economic development in the region]. Podilskyi visnyk: silske hospodarstvo, tekhnika, ekonomika, 27, 298-308. Retrieved from http://188.190.33.56:7980/ jspui/bitstream/123456789/2458/1/PB-27-298-308. pdf (in Ukr.).

5. Derzhavna Stratehiia rehionalnoho rozvytku Ukrainy na period do 2020 roku (2013). [State Strategy of Regional Development of Ukraine for the period till 2020]. Retrieved from http://www.csi.org.ua/ www/wp-content/uploads/2013/05/nsrdu2020_1.pdf (in Ukr.).

6. Zhavoronkova, G. (2010). Stratehichne upravlinnia rozvytkom rehionu [Strategic management of the development of the region]. Problemy ekolohichnoi biotekhnolohii, 1, 26-31 (in Ukr.).

7. The Verkhovna Rada Ukraine (2012). Pro stymuliuvannia rozvytku rehioniv [On stimulating the development of regions]. Retrieved from http://zakon. rada.gov.ua/laws/show/2850-15 (in Ukr.).

8. Berdyansk City Council (2018). Stratehiia rozvytku $\mathrm{m}$. Berdianska na period do 2027 roku [Strategy of development of the city of Berdyansk for the period up to 2027]. Retrieved from http://pleddg.org.ua/ wp-content/uploads/2018/09/Strategiya-Berdyansk. pdf (in Ukr.).

9. Meddok, K., Myrnska, O., Tkachuk, A., Tretyak, Yu. (2014). Rehionalnyi rozvytok ta derzhavna rehionalna polityka $v$ Ukraini: stan $i$ perspektyvy zmin u konteksti hlobalnykh vyklykiv ta yevropeiskykh standartiv polityky. Analitychnyi zvit [Regional Development and State Regional Policy in Ukraine: Status and Prospects for Change in the Context of Global Challenges and European 
Policy Standards. Analytical report]. Kyiv, Proekt YeS «Pidtrymka polityky rehionalnoho rozvytku v Ukraini (in Ukr.).

10. Berdyansk City Council (2018). Stratehiia rozvytku m. Berdianska na period do 2027 roku [Strategy of development of the city of Berdyansk for the period up to 2027]. Retrieved from http://pleddg.org.ua/wp-
content/uploads/2018/09/Strategiya-Berdyansk.pdf (in Ukr.).

11. Panukhnik, O. (2011). Metodychne zabezpechennia strate - hichnoho planuvannia $v$ rehionakh Ukrainy [Methodical provision of strategic planning in the regions of Ukraine]. Aktualni problemy ekonomiky, 1 (91), 152-157 (in Ukr.). 


\title{
ГРОШІ, ФІНАНСИ І КРЕДИТ
}

\section{НАПРЯМИ ТА ІНСТРУМЕНТИ УДОСКОНАЛЕННЯ ФІНАНСОВОЇ ПОЛІТИКИ В УКРАЇНІ}

\begin{abstract}
Анотація. У статті обгрунтовано важливість удосконалення фінансової політики як основи будь-якоі соціально- та виробничо-економічної діяльності, ї̈ основні структурні складники, визначено бюджетноподаткову, грошово-кредитну політику управління державним боргом; функціональних - управління фінансовими ресурсами та забезпечення бюджетної безпеки. Встановлено екзогенні й ендогенні чинники, які впливають на ефективність здійснення фінансової політики та можуть бути їі наслідками. Це державний борг, бюджетний дефіцит, не раціональні витрати фінансових ресурсів. Визначено пріоритетні напрями та інструменти удосконалення фінансової політики, у т. ч. на рівні фінансових інститутів.
\end{abstract}

Ключові слова: управління, фінансова політика, бюджетна безпека, державний борг, дефіцит, соціально-економічні процеси, інструменти, економічне зростання, пріоритети.

Summary. The article substantiates the importance of improving financial policy as the basis of any socioindustrial and economic activities. As its main structural components are defined fiscal, monetary and debt management policies; functional - financial management and ensure fiscal security. Set of exogenous and endogenous factors that affect the effectiveness of the implementation of financial policies and may be its consequences. This public debt, budget deficit, not the rational spending of financial resources. Defined priorities and tools for improving the financial policies, including the level of financial institutions.

Key words: management, fiscal policy, fiscal security, national debt, deficit, socio-economic processes, tools, economic growth, priorities.

$$
\text { DOI : } 10.33783 / 1977-4167-2019-46-2-126-129
$$

Постановка проблеми. Важливим завданням державної фінансової політики в Україні є нарошування фінансових ресурсів загалом на основі зростання базових факторів формування ВВП. Одним із важливих елементів фінансової політики має стати ії спрямованість на усунення диспропорцій у розподілі первинних доходів між працею, капіталом і державою. Фінансова політика відіграє важливу роль для зростання національної економіки, добробуту населення, підвищення обороноздатності країни. Тому розгляд пропонованої теми завжди є актуальним і потребуватиме подальших досліджень та розробок і обгрунтувань.

Аналіз останніх досліджень і публікацій. Дослідженням фінансової політики та бюджетної безпеки держави займалися такі відомі українські науковці, як: О. Білик, Т. Боголіб, І. Валуйський, Е. Гатаулліна, Л. Зверук, В. Кравець, В. Малишко, С. Онищенко, Т. Сіташ, О. Тарасова, В. Ящук та ін. Ïх здійснення має базуватися на науково обгрунтованій концепції економічного розвитку суспільства та давати реальні поточні та стратегічні результати. Проте окремі складові такої політики та напрями iii розвитку є недостатньо дослідженими дотепер та потребують подальшого наукового опрацювання $з$ огляду на нові чинники й обставини реалізації.

Мета статті - дослідити рівень здійснення фінансової політики та бюджетної безпеки країни й ефективності управління ними з урахуванням нових чинників їх забезпечення та розробити відповідні інструменти удосконалення і підвищення на перспективу.

Виклад основного матеріалу дослідження. Фінансова діяльність та управління нею є однією з головних сфер діяльності, яка спрямована на ефективний розподіл фінансових ресурсів та їх використання для забезпечення сталого розвитку країни. Завданнями, які ставляться перед фінансовою політикою, є ефективний розподіл фінансових ресурсів, формування механізму фінансового управління, а також регулювання і стимулювання економічних і соціальних процесів. Щоб покращити добробут громадян, фінансова політика повинна мати за мету підвищувати зростання економіки, а для цього потрібно забезпечувати рівень оптимізації розподілу валового вну-

(C) В. В. Малишко, 2019

Бібліографія ДСТУ 8302:2015:

Малишко В. В. Напрями та інструменти удосконалення фінансової політики в Україні. Вісник Бердянського університету менеджменту і бізнесу. 2019. № 2 (46). С. 126-129.

References (APA):

Malyshko, V. V. (2019). Napriamy ta instrumenty udoskonalennia finansovoi politykyv Ukraini [Directions and tools for improving the financial policy in Ukraine]. Visnyk Berdianskoho universytetu menedzhmentu i biznesu, 2 (46), 126-129 (in Ukr.). 
трішнього продукту. Фінансова політика повинна мати чітку стратегію та враховувати можливості й потреби національної економіки.

На думку Е. Гатаулліної, «пріоритетними заходами державної фінансової політики, які реалізуються у країнах з розвинутою на трансформаційною економікою, є підвищення фіскальної ефективності податкової системи, удосконалення системи управління державними фінансами, підвищення дієвості механізму середньострокового бюджетного планування та прогнозування, зниження показників структурного дефіциту бюджету та державного боргу, оптимізація видаткової частини бюджету» [1].

Фінансова політика є одним з основних інструментів для розвитку суспільства та регулювання соціально-економічних процесів на національному рівні. У період структурних реформ потрібно посилювати вплив такого інструменту, як державна фінансова політика на економіку держави, удосконалювати механізми для економічного зростання. Дуже важливим є створення такої структури фінансової системи, яка б базувалася на взаємодії державного регулювання економічних процесів та механізмів саморегулювання, а для цього потрібна відповідна інституційна система з розвинутими фінансовими інститутами.

Пристосування до змін у структурі фінансових відносин, впливу зовнішніх економічних факторів - це важливе завдання фінансово-економічної політики. Так, В. Кравець у своєму дослідженні зазначила, що «при формуванні фінансової політики на середньострокову перспективу необхідним є врахування впливу екзогенних та ендогенних факторів на економічну систему, які визначають тенденції соціально-економічного розвитку.

До екзогенних факторів належать темпи зростання валового внутрішнього продукту країн, що формують попит на основні групи товарів вітчизняного експорту, рівень цін на продукти експорту та імпортовані енергоносії, обсяги та структура іноземних інвестицій, кон'юнктура на світових фінансових ринках, яка впливає на можливості держави здійснювати запозичення та операції по рефінансуванню державного боргу. До внутрішніх економічних факторів належить частка перерозподілу валового внутрішнього продукту через бюджет та державні цільові фонди, прогнозований обсяг бюджетних доходів та видатків, дефіциту (профіциту) бюджету, обсяг прямого та гарантованого державного боргу, показники співвідношення заощаджень та інвестицій в економіку, грошово-кредитного регулювання» [2].

Як було досліджено у попередніх роботах, «реалізація фінансової політики держави здійснюється у вигляді комплексу заходів, які втілюються через фінансове право, фінансову систему і фінансовий механізм з метою найбільш повного виконання фінансами своїх функцій. Через норми фінансового права та елементи фінансової системи і фінансового механізму здійснюється реалізація положень концепції економічного розвитку держави. Якщо остання відсутня, то навряд чи можна говорити про будь-яку фінансову політику в державі» [3, с. 4.3].

На сьогодні вітчизняні вчені, досліджуючи фінансову політику країни, зазначають, що головними іiі проблемами є недостатня конкурентоспроможність та відсутність суттєвої динаміки зростання української економіки, а також необхідність запровадження нової моделі фінансового розвитку. Якщо вирішити зазначені проблеми належним чином - це дасть нашій державі рух вперед і вона буде займати вищі позиції в рейтингах серед найрозвинутіших країн світу. Т. Сіташ зазначила, що поглиблення курсу ринкових реформ на інноваційних засадах та їх прискорення, радикалізація системних перетворень можуть забезпечити прогресивний розвиток держави [4].

Державна фінансова політика є важливою складовою економічної політики держави. До основних видів фінансової політики держави можна віднести бюджетно-податкову політику, грошово-кредитну політику та політику управління державним боргом. Ці види розкривають сутність та формування фінансової політики держави в цілому, адже саме від їх показників залежать економічний розвиток та бюджетна безпека країни. Фінансова політика нинішнього етапу розвитку розроблена на основі вимог фінансової стратегії та з урахуванням сформованих економічних умов. Вона передбачає подолання кризового стану, в якому знаходяться фінанси сучасності.

Для цього потрібно створити таку систему, яка стимулюватиме до ефективного управління державними фінансовими ресурсами. На нашу думку, важливими чинниками, що впливають на негативний розвиток фінансової політики та бюджетної безпеки, виступає великий дефіцит державного бюджету, зростання внутрішнього і зовнішнього державного боргу, наявність великої кількості збиткових і малорентабельних підприємств, зростання незавершеного будівництва. Для їх подолання потрібно виробити таку стратегію, яка б давала змогу уникати цих явищ та знаходити оптимальні шляхи їх подолання. Фінансова політика, що реалізується через фінансову систему країни, не відповідає стандартам економічно розвинених країн ЕС.

Як стверджує В. Ящук, «основними напрямами фінансової політики на середньострокову перспективу є оптимізація розміру бюджетного дефіциту, підвищення ефективності формування видатків бюджету, використання бюджетних коштів, посилення регулюючої функції податкової системи, проведення ліберальної монетарної 
політики, удосконалення системи управління державними фінансами з одночасним стимулюванням економічного зростання шляхом використання відповідних інституційних фінансових механізмів» [5]. Л. Зверук та О. Білик вказують, що «бюджетна безпека - це спроможність бюджетної системи забезпечити фінансову самостійність та стійкість держави ефективного використання нею бюджетних коштів у процесі виконання функцій соціального захисту; державного управління і міжнародної діяльності; фінансування науки, освіти, культури і охорони здоров'я; забезпечення національної безпеки й оборони, реалізації інвестиційної та екологічної політики» [7].

Доповненням до попереднього визначення Л. Зверук зазначає, що «бюджетна безпека держави - стан забезпечення платоспроможності (рівень бюджетного потенціалу) держави щодо виконання нею своїх функцій з урахуванням балансу доходів і видатків державного й місцевих бюджетів та доцільності, законності й ефективності використання бюджетних коштів на всіх рівнях» [8]. Проаналізувавши термін «бюджетна безпека», можна зауважити, що найважливішими iii критеріями є ефективне використання позикових коштів для фінансування бюджетних видатків, визначення необхідних цілей, які б відповідали інтересам держави, контроль за ефективністю використання бюджетних коштів, згідно з бюджетним законодавством.

Бюджетна безпека - це фінансова стійкість державних фінансів, а також допомога органам державної влади ефективно виконувати свої функції. Вона оцінюється через відношення дефіциту (профіциту) державного бюджету до ВВП, у відсотках; рівень перерозподілу ВВП через зведений бюджет, \%; відношення обсягу сукупних платежів з обслуговування та погашення державного боргу до доходів державного бюджету, \% [8].

Основними характеристиками бюджетної безпеки має бути співвідношення доходів до видатків державного та зведеного бюджетів. Якщо ці характеристики не задовольнятимуть бюджетну безпеку, то будуть порушуватися й інші індикатори. Також вважається, що співвідношення податкових до неподаткових надходжень забезпечує нестабільність бюджетних доходів у цілому, але податкові надходження більш стабільні, економічно обгрунтовані і через це вони позитивно впливають на рівень бюджетної безпеки загалом.

На нашу думку, економічне зростання країни буде досягнуто, якщо буде зменшене податкове навантаження на вітчизняних виробників продукціi. Також зменшення видатків держави приведе до зменшення дефіциту бюджету України. Саме ці показники будуть пріоритетними напрямами реформування економіки країни на перспективу [9]. Основними загрозами для бюджетної безпе- ки є: високий рівень державного боргу; дефіцит державного бюджету; збільшення частки видатків державного бюджету на фінансування потреб національної оборони та безпеки.

Для зміцнення бюджетної безпеки органи управління мають створити таке середовище діяльності (економічне, соціальне, політичне, інституційне), яке буде збалансовувати бюджетний та податковий процеси. Ці процеси повинні мати важливі пріоритети: розробка механізмів для уникнення загроз бюджетній системі держави; підтримка бюджетної спроможності; розвиток бюджетної децентралізації; зменшення бюджетного дефіциту і державного боргу; а також контроль за фінансовими ресурсами; впровадження інноваційних методів та інструментів в управління державними фінансами і бюджетною безпекою; розвиток концепції соціальної відповідальності у діяльності всіх стейкхолдерів [10].

Висновки. Фінансова й бюджетна діяльність є важливою складовою економічної стратегії держави, яка забезпечує економічне зростання та має чітке спрямування. Напрями та інструменти їх забезпечення, управління й регулювання є запорукою фінансової стійкості суб'єктів господарювання, сталого розвитку національного господарства і довкілля, збереження цілісності та єдності фінансової системи й подолання різного роду загроз у соціально-економічній та екологічній сферах, а також у сфері національної безпеки й оборони. Управління державними фінансами, бюджетною діяльністю та регулювання їх розвитку на перспективу повинне враховувати досвід та досягнення й надбання інших країн у цій сфері.

\section{Література}

1. Гатаулліна Е. I. Державна фінансова політика у країнах з розвинутою та трансформаційною економікою. URL : http://nbuv.gov.ua/UJRN/ ecvu_2015_27\%281\%29_25.

2. Кравець В. І. Основні напрями фінансової політики в умовах економічних перетворень. URL: http://www.economy.in.ua/?op $=1 \& z=4151 \& \mathrm{i}=8$.

3. Малишко В. В., Пучко А. О. Фінансова політика України на сучасному етапі. Траектория науки. 2017. Т. 3, № 1. С. 4.1-4.8.

4. Сіташ Т. Д. Фінансова політика держави: прагматика та проблематика. Академічний огляд. 2015. №1 (42). C. 29-34. URL : http://nbuv.gov.ua/ UJRN/ao_2015_1_6.

5. Ящук В. В. Фінансова політика в умовах економічних перетворень. URL: https://knteu.kiev. $\mathrm{ua} /$ file/NzM1OQ==/ab0627d04c00563fc649a7575c b93e21.pdf.

6. Тарасова О. В. Фінансова політика і бюджетна безпека України. Економіка харчової промисловості. 2018. Т. 10, Вип. 1. С. 76-80. URL : http://nbuv.gov.ua/UJRN/echp_2018_10_1_11. 
7. Зверук Л. А., Білик О. Г. Бюджетна безпека як важливий пріоритет розвитку бюджетної системи України. Міжнародний науковий журнал «Інтернаука». Серія : Економічні науки. 2017. № 2. C. 35-39. URL : http://nbuv.gov.ua/UJRN/ mnjie 2017228.

8. Зверук Л. А. Фінансова безпека - основа стабільного розвитку України. Бізнес Інформ. 2016. № 7. C. 131-135. URL : http://nbuv.gov.ua/ UJRN/binf_2016_7_21.

9. Валуйський I. А. Сучасний стан забезпечення бюджетної безпеки України. URL : http://www.confcontact.com/2016-ekonomika-imenedzhment/7_val yjskij.htm.

10. Ihnatenko M., Antoshkin V., Krukovska O., Malyshko V., Marmul L. Social Investments as the Highest Manifestation of Implementation of Social Responsibility of the Companies of Agribusiness. International Journal of Recent Technology and Engineering (IJRTE), 3 (8), 2019. P. 7124-7132.

\section{References}

1. Gataullina, E. I. (2015). Derzhavna finansova polityka u krayinah z rozvynutoyu ta transformacijnoyu ekonomikoyu [Government fiscal policy in countries with developed and transitional economy]. Retrieved from http://nbuv.gov.ua/UJRN/ecvu_2015 $27 \% 281 \% 29 \quad 25$.

2. Kravets, V. I. (2018). Osnovni napryamy finansovoyi polityky $v$ umovah ekonomichnyh peretvoren [The Main directions of financial policy in the conditions of economic transformation]. Retrieved from http://ww $=1 \& \mathrm{z}=4151 \& \mathrm{i}=8$.

3. Malyshko, V. V. (2017). Finansova polityka Ukrayiny na suchasnomu etapi [Financial policy of Ukraine at the modern stage]. Traektoriâ nauki, 1(3), 4.1-4.8.
4. Sitash, T. D. (2015). Finansova polityka derzhavy: pragmatyka ta problematyka [Financial policy: pragmatics and issues]. Akademichnyi ohliad, 1 (42), 29-34. Retrieved from http://nbuv.gov.ua/ UJRN/ao_2015_1_6.

5. Yaschuk, V. V. (2016). Finansova polityka $v$ umovah ekonomichnyh peretvoren [Financial policy in terms of economic reforms]. Retrieved from https:// knteu.kiev.ua/file/NzM1OQ==/ab0627d04c00563fc 649a7575cb93e21.pdf.

6. Tarasova, O. V. (2018). Finansova polityka I byudzhetna bezpeka Ukrayiny [Fiscal policy and budget security of Ukraine]. Retrieved from http://nbuv. gov.ua/UJRN/echp_2018_10_1_11.

7. Zveruk, L. A., Bilyk, O. G. (2017). Byudzhetna bezpeka yak vazhlyvyj priorytet rozvytku byudzhetnoyi systemy Ukrayiny [Fiscal security as an important priority in the development of the budget system of Ukraine]. Retrieved from file://C:/Users/user/ Downloads/mnjie $201728 \% 20$ (2).pdf.

8. Zveruk, L. A. (2017). Finansova bezpeka osnova stabilnogo rozvytku Ukrayiny [Financial security is the basis for sustainable development of Ukraine]. Retrieved from http://nbuv.gov.ua/UJRN/mnjie_ 201728.

9. Valuyskiy, I. A. (2016). Suchasnyj stan zabezpechennya byudzhetnoyi bezpeky Ukrayiny [Modern state of budgetary security of Ukraine]. Retrieved from http://www.confcontact.com/2016-ekonomikai-menedzhment/7_valyjskij.htm.

10. Ihnatenko, M., Antoshkin, V., Krukovska, O., Malyshko, V., Marmul, L. (2019). Social Investments as the Highest Manifestation of Implementation of Social Responsibility of the Companies of Agribusiness. International Journal of Recent Technology and Engineering (IJRTE), 3 (8), P. 7124-7132. 


\title{
БУХГАЛТЕРСЬКИЙ ОБЛІК, АНАЛІЗ І АУДИТ
}

\section{ОРГАНІЗАЦІЯ Й МЕТОДИКА ОБЛІКУ РОЗРАХУНКОВИХ ОПЕРАЦІЙ АГРАРНИХ ПІДПРИЕМСТВ ТА НАПРЯМИ ЇХ УДОСКОНАЛЕННЯ}

\begin{abstract}
Анотація. У статті виявлені особливості організації та здійснення обліку розрахункових операцій аграрних підприємств. Виявлені їх вузькі місия та джерела можливих зловживань. Вказані основні нормативні документи та міжнародні й національні стандарти забезпечення бухгалтерського обліку. Здійснено також класифікацію розрахункових операцій, а також використання для їх обліку балансових та позабалансових рахунків. Обгрунтовано, що для удосконалення організації та обліку розрахунків та збільшення значущості їх використання в управлінні доцільним є посилення достовірності аналітичної складової обліку. Для цього було розроблено напрями практичного вирішення вказаного завдання.
\end{abstract}

Ключові слова: аграрні підприємства, організація, облік, розрахункові операції, особливості, баланс, позабалансові рахунки, договори, контракти, міжнародні й національні стандарти.

Summary. The article reveals the features of the organization and implementation of accounting of settlement operations of agricultural enterprises. Their bottlenecks and sources of possible abuses are revealed. The main normative documents and international and national accounting standards are specified. The classification of settlement transactions, as well as the use of balance sheet and off-balance sheet accounts for their accounting, has also been carried out. It is proved that in order to improve the organization and accounting of calculations and increase the importance of their use in management, it is expedient to strengthen the reliability of the analytical component of accounting. For this purpose directions of the practical solution of the specified problem have been developed.

Key words: agricultural enterprises, organization, accounting, settlement operations, in particular, balance sheet, off-balance sheet accounts, contracts, contracts, international and national standards.

$$
\text { DOI : 10.33783/1977-4167-2019-46-2-130-133 }
$$

Постановка проблеми. У новій ринковій економіці підприємства, у т. ч. аграрні, функціонують на основі різних форм власності і 3 застосуванням різних організаційно-правових форм - приватної, спільної, кооперативної та ін. Тому іншого значення й функцій набули облік і оцінка результатів господарської діяльності. Це стало необхідним для встановлення майнових відносин із засновниками, інвесторами, контрагентами, орендарями й орендодавцями, а також $з$ державою - із приводу сплати податків і інших обов'язкових платежів до бюджету та позабюджетних фондів.

Публічні інтереси зажадали, щоб бухгалтерський облік майна, зобов'язань, усіх господарських операцій, виявлення результатів їхнього проведення, об'єктів оподатковування тощо проводилися за єдиними правилами. Це дає можливість забезпечити порівнюваність та певну уніфікацію усіх фінансових відносин підприємств із державою, іншими суб'єктами, що мають право вимагати представлення інформації про діяльність аграрних підприємств.

Господарська діяльність будь-якого суб'єкта аграрного господарювання пов'язана з використанням коштів, матеріальних і нематеріальних цінностей. Основою їх безперервного колообігу $є$ господарські процеси. Однією з важливих передумов подальшої діяльності аграрних підприємств $€$ процес постачання, що тісно пов'язаний з розрахунковими операціями, які можуть призводити до утворення зобов'язань. Через різницю у часі між моментами постачання та сплати за рахунками в аграрних підприємств виникає поточна кредиторська заборгованість за товари, роботи та послуги.

Даний вид зобов'язань є тимчасово вільними обіговими коштами та здійснює суттєвий вплив на фінансову стійкість і платоспроможність суб'єкта господарювання. Тому їх розмір потрібно ретельно контролювати. Причиною виникнення значної кредиторської заборгованості часто стає недосконалість розрахунків з постачальниками та

(C) С. В. Коваль, 2019

Бібліографія ДСТУ 8302:2015:

Коваль С. В. Організація й методика обліку розрахункових операцій аграрних підприємств та напрями їх удосконалення. Вісник Бердянського університету менеджменту і бізнесу. 2019. № 2 (46). С. 130-133.

References (APA):

Koval, S. V. (2019). Orhanizatsiia y metodyka obliku rozrakhunkovykh operatsii ahrarnykh pidpryiemstv ta napriamy yikh udoskonalennia [Organization and methodology of accounting of settlement operations of agricultural enterprises and directions of their improvement]. Visnyk Berdianskoho universytetu menedzhmentu i biznesu, 2 (46), 130-133 (in Ukr.). 
підрядниками, недбалість і помилки працівників, шахрайство та зловживання службовими повноваженнями.

Як наслідок - порушення фінансової й розрахункової дисципліни. Тому правильне, ефективне та своєчасне ведення розрахунків 3 постачальниками та підрядниками, достовірне відображення облікової та аналітичної інформації щодо розрахункових операцій набуває великого значення, спонукає необхідність їх вдосконалення. Тому обрана тематика досліджень є актуальною та своєчасною.

Аналіз останніх досліджень і публікацій. Необхідно зазначити, що вирішенню проблем організації та бухгалтерського обліку розрахункових операцій суб'єктів господарювання агросфери присвячені праці вітчизняних науковців: Л. Мармуль, В. Плаксієнка, Л. Рибіної, О. Сарапіної, О. Шевчук та ін.

Мета статті - виявити особливості організації та обліку здійснення розрахункових операцій аграрних підприємств та обгрунтувати напрями їх удосконалення.

Виклад основного матеріалу дослідження. Одним із важливих інструментів управління щодо зміцнення фінансово-економічного становища підприємств агросфери є контроль за фактичним станом їх розрахунків, динамікою дебіторської та кредиторської заборгованості, виявлення фактів навмисного спотворення облікових даних суб'єктами господарських зв'язків. При цьому важливого значення набувають питання законності обмінних операцій, їх доцільності, документальної обгрунтованості та правильності відображення у бухгалтерському обліку та обліково-фінансовій звітності.

Існуючі методологічні засади управління, як і практика організації бухгалтерського обліку розрахунків, не завжди використовують можливості посилення позитивного впливу обліку і контролю за дотриманням розрахунково-платіжної дисципліни суб'єктів підприємницької діяльності. Тому одними із напрямів вирішення проблеми ефективного управління розрахунками є виявлення адекватних їхній сутності класифікаційних ознак, розроблення науково-обгрунтованої системи їх обліку. Поряд з цим, додаткового осмислення потребує низка питань, пов'язаних зі зростанням ролі розрахунків як важливішого об'єкта обліку: питання обліку договірних зобов'язань і прав; створення умов поліпшення облікової інформації та приведення ï у відповідність до потреб зовнішніх й внутрішніх користувачів.

Розвиток товарного аграрного виробництва у світі склав підгрунтя інтернаціоналізації економіки і агробізнесу, зумовив потребу в уніфікованій системі розвинених розрахунків і вплинув на формування вимог до їх механізму. 3 точки зору дер- жавних інтересів готівково-грошові розрахунки ускладнюють здійснення контролю за грошовим обігом юридичних і фізичних осіб. Тому в Україні прийняте законодавство, що обмежує готівковогрошові розрахунки і передбачає особливу систему контролю за їх здійсненням.

Нині в обліково-економічній літературі не виділено чітке поняття форми розрахунків. Зокрема, Л. Рибіна, викладаючи власне розуміння цієї категорії, визначає форму розрахунків як «...вид носіїв боргових вимог на кошти, які відрізняються структурою документів і документообігом, часом і місцем виконання розрахунків, ступенем гарантії платежів» [1, с. 156]. Чинне законодавство України не розкриває змісту терміна «форма розрахунків», натомість наводиться перелік форм розрахунків, які застосовують при проведенні переказу, а саме: «акредитивна, вексельна, інкасова, за гарантійними зобов'язаннями, за чеками, з використанням документів на переказ».

Результати проведених досліджень свідчать, що поняття «розрахунок» та «платіж» тісно пов'язані. Так, наприклад, В. Ющенко дає таке визначення безготівкових розрахунків: «безготівкові розрахунки - це платежі, що здійснюються як у вигляді матеріального обігу паперових документів, так і у вигляді магнітних записів, магнітного зчитування, руху електронних повідомлень» [2, с. 18]. Економічна енциклопедія трактує поняття «платіж» як фінансово-грошові операції, пов'язані з розрахунками громадян, підприємств і організацій між собою, а також органами фінансово-кредитної системи [3, с. 754]. Сучасний економічний словник визначає поняття розрахунку як сплату грошей за зобов'язаннями [4, с. 26].

Методологічні засади формування в бухгалтерському обліку інформації про фінансові інструменти та ii розкриття у фінансовій звітності визначаються П(С)БО 13 «Фінансові інструменти», згідно з яким фінансовий інструмент - це контракт, який одночасно приводить до виникнення (збільшення) фінансового активу в одного підприємства і фінансового зобов'язання або інструмента власного капіталу в іншого. На це вказують Л. Мармуль, В. Плаксієнко, С. Скрипник та інші автори науково-навчального видання [5, c. 176].

Аналогічно дане поняття трактується у міжнародних стандартах фінансової звітності IAS 32 «Фінансові інструменти». Таким чином, фінансові інструменти включають як первісні інструменти, наприклад, дебіторську й кредиторську заборгованість та цінні папери, які надають право власності, так і похідні інструменти, наприклад, фінансові опціони, ф’ючерсні та форвардні контракти.

Отже, платіжними інструментами розрахункових відносин можуть бути також фінансові 
інструменти, що призводить до виникнення певних особливостей стосовно об'єктів обліку в розрахунках, а саме: фінансові інструменти, на відміну від розрахунково-платіжних документів, $є$ самостійними об'єктами бухгалтерського обліку. Використання фінансових інструментів у розрахунках надає підприємствам більш широкі можливості у прийнятті рішень щодо забезпечення своєчасного виконання зобов'язань.

На особливості методики бухгалтерського обліку безготівкових розрахунків із використанням платіжних вимог впливає також предмет розрахунків. Як правило, ним може бути заборгованість перед бюджетом, заборгованість перед митними органами, фіктивні кошти, які незаконно перебувають в обігу, сума фінансових санкцій, висунутих підприємству за порушення розрахунків з бюджетом, сума боргу за векселем, розрахунки за претензіями. У разі стягнення коштів як фінансових санкцій зазначені суми у бухгалтерському обліку відображаються у складі витрат звітного періоду з відповідним впливом на фінансові результати, що відображені саме в бухгалтерському обліку [6, с. 73].

При цьому особливості методики обліку безготівкових розрахунків визначаються залежно від таких характеристик господарської операції:

1. Місцезнаходження економічного агента.

2. Наявність фактичного руху коштів при здійсненні розрахунків.

3. Результати здійснення розрахунків: за вершення господарської операції або утворення дебіторської (кредиторської) заборгованості.

Вибір ефективної форми розрахунків сприяє поліпшенню фінансового стану підприємства, зростанню його прибутку без залучення додаткових капітальних вкладень [7, с. 49]. Тому в умовах ринку вибір форми розрахунків, на нашу думку, необхідно здійснювати за такими критеріями: надійність, шляхом гарантування своєчасності надходження коштів на рахунок виробника продукції в повному обсязі; контроль через належний рівень взаємного і банківського контролю за виконанням договірних зобов'язань; прискорення документообігу; пришвидшення обігу коштів через скорочення термінів отримання товарно-матеріальних цінностей і термінів їх оплати покупцями; мінімальна трудомісткість розрахункових операцій.

У ринковому середовищі аграрна підприємницька діяльність будується також на системі укладених договорів постачання продукції (робіт, послуг). Оскільки договір є основним інструментом, який переміщує матеріальні та фінансові ресурси підприємства, то причини, які створюють передумови до виникнення і несвоєчасного погашення заборгованостей, можуть випливати, власне, із господарських договорів [8, с. 49].
Для узагальнення інформації про наявність та рух зобов'язань по укладених контрактах, а також контролю за їх виконанням призначено позабалансовий бухгалтерський рахунок 03 «Контрактні зобов'язання». Слід зауважити, що План рахунків бухгалтерського обліку підприємств і організацій розглядає можливість обліку деривативів та інших контрактів, розкриття інформації щодо яких передбачено відповідними Положеннями (стандартами) бухгалтерського обліку [9, с. 51].

Для аграрного виробника традиційним залишається укладання господарських договорів товарного змісту, а операції за деривативом можна віднести до категорії другорядних. У зв’язку з цим доцільно в сучасних умовах господарювання введення в облік таких позабалансових рахунків, як «Договірні права» та «Договірні зобов’язання». Головною особливістю, яка визначає прийоми та методи відображення господарських договорів на позабалансових рахунках, є врахування такої умови договору, як спосіб оплати (повна передоплата, часткова передоплата, оплата після одержання продукції).

Висновки. Як показало здійснене дослідження, напрями удосконалення організації та обліку розрахункових взаємовідносин суб'єктів господарювання пов'язані з підвищенням аналітичної цінності облікової інформаціі. Тому під час побудови аналітичного обліку розрахункових відносин необхідно звернути увагу на низку важливих моментів. До них належать:

1. Класифікація розрахунків за економікоправовим змістом. Розрахунки за попередньо укладеними договорами пропонуємо класифікувати як комерційні, що, своєю чергою, поділяються залежно від об'єктів обліку на товарні та фінансові.

2. Встановлення видів господарських договорів (договір купівлі-продажу, договір постачання, договір підряду, договір бартеру, договір про надання послуг, договір зберігання, договір оренди, договір про товарний кредит).

3. Аналітичний облік необхідно вести за кожним окремим договором та суб'єктом договірних зв'язків.

4. Встановлення суми прострочених зобов'язань та розрахунку величини матеріального відшкодування необхідно здійснювати на основі врахування умов та строків розрахунків.

\section{Література}

1. Рибіна Л. А. Роль безготівкових розрахунків в поліпшенні фінансового становища підприємств. Вісник Сумського сільськогосподарського інституту. 2012. Вип. 1. С. 155-157.

2. Ющенко В. А., Савченко А. С., Цокол С. Л. Платіжні системи : навчальний посібник для студентів вищих закладів освіти. К. : Либідь, 1998.416 c. 
3. Економічна енциклопедія : У трьох томах. Т. 2. / редкол.: С. В. Мочерний (відп. ред.) та ін. К. : Академік, 2001. 848 с.

4. Кірейцева Г. Г. Фінансовий менеджмент : навч. посіб. К. : ЦУЛ, 2010. 496 с.

5. Плаксієнко В. Я., Маренич Т. Г., Мармуль Л. О. Бухгалтерський облік у виробничих та агросервісних кооперативах. К. : Центр учбової літератури, 2014. 448 с.

6. Шевчук О. А. Аспекти бухгалтерського та податкового обліку безготівкових розрахунків. Фінанси України. 2011. № 2. С. 69-76.

7. Романюк I. А. Розвиток системи оподаткування підприємств туристичного бізнесу в Україні. Сучасний стан та пріоритети розвитку системи обліку, оподаткування й аналізу виробничо-економічної діяльності суб'єктів господарювання агропромислового сектору економіки : колективна монографія / за заг. ред. Л. О. Мармуль. Херсон : Айлант, 2018. С. 47-55.

8. Петрук О. М. Бухгалтерський облік договірних зобов'язань і прав : навч. посіб. Житомир: ЖITI, 2009. $186 \mathrm{c}$.

9. Ігнатенко М. М., Сарапіна О. А. Вплив автоматизації обліку та фінансової звітності на безпеку підприємств. Економічний вісник університеmу. 2018. Вип. (1) 38. С. 47-53.

\section{References}

1. Rybina, L. A. (2012). Rol bezghotivkovykh rozrakhunkiv $v$ polipshenni finansovoho stanovyshcha pidpryiemstv [The role of non-cash payments in improving the financial position of enterprises]. Visnyk Sumskoho silskohospodarskoho instytutu, 1, 155-157 (in Ukr.).

2. Yushchenko, V. A., Savchenko, A. S. \& Tsokol, S. L. (1998). Platizhni systemy [Payment systems]. Kyiv, Lybid (in Ukr.).
3. Mochernyy, S. V. (2001). Ekonomichna entsyklopediya [Economic Encyclopedia]. Kyiv, Akademik (in Ukr.).

4. Kireytseva, H. H. (2010). Finansovyy menedzhment [Financial Management]. Kyiv, TSUL (in Ukr.).

5. Plaksiyenko, V. YA., Marenych, T. H. \& Marmul, L. O. (2014). Bukhhalterskyi oblik u vyrobnychykh ta ahroservisnykh kooperatyvakh [Accounting in production and agro-service cooperatives]. Kyiv, Tsentr uchbovoyi literatury (in Ukr.).

6. Shevchuk, O.A. (2011). Aspektybukhhalterskoho ta podatkovoho obliku bezghotivkovykh rozrakhunkiv [Aspects of accounting and tax accounting of noncash payments]. Finansy Ukrayiny, 2, 69-76 (in Ukr.).

7. Romanyuk, I. A. (2018). Rozvytok systemy opodatkuvannya pidpryyemstv turystychnoho biznesu $v$ Ukrayini [Development of taxation system for tourist business enterprises in Ukraine]. In Marmul, L. O. (ed.) Suchasnyi stan ta priorytety rozvytku systemy obliku, opodatkuvannia y analizu vyrobnychoekonomichnoi diialnosti subiektiv hospodariuvannia ahropromyslovoho sektoru ekonomiky [Current status and priorities of the development of accounting, taxation and analysis of production and economic activity of economic entities of the agro-industrial sector of the economy], 47-55. Kherson, Aylant (in Ukr.).

8. Petruk, O. M. (2009). Bukhhalterskyi oblik dohovirnykh zoboviazan i prav [Accounting for contractual obligations and rights]. Zhytomyr, ZHITI (in Ukr.).

9. Ihnatenko, M. M. \& Sarapina, O. A. (2018). Vplyv avtomatyzatsiyi obliku ta finansovoyi zvitnosti na bezpeku pidpryyemstv [Impact of accounting automation and financial reporting on enterprise security]. Ekonomichnyy visnyk universytetu, (1) 38, 47-53 (in Ukr.). 


\title{
ОРГАНІЗАЦІЙНО-ОБЛІКОВЕ ЗАБЕЗПЕЧЕННЯ МАЙНА ТА КАПІТАЛІВ СІЛЬСЬКОГОСПОДАРСЬКИХ ВИРОБНИЧИХ КООПЕРАТИВІВ
}

\begin{abstract}
Анотація. У статті розглянуті нормативно-правові акти, методичні рекомендації та розробки, облікові форми, положення та стандарти, які регламентують формування та здійснення обліку майна і капіталів у сільськогосподарських виробничих кооперативах (СВК). Встановлені їх відмінності від аналогічних процедур організації та обліку в аграрних підприємствах. Зокрема, ідеться про відсутність статутного капіталу та представлення його інших видів. Також виявлені джерела формування майна та капіталів СВК та їх відображення на субрахунках в обліку. Велику увагу приділено формуванню пайового капіталу та різних фондів кооперативів, а також різних видів виплат, порядку їх здійснення та відображення в обліку. Здійснено оцінювання руху майна, капіталів, а також виплат та їх обліку. Розроблені заходи щодо удосконалення їх організаційно-облікового забезпечення.
\end{abstract}

Ключові слова: сільськогосподарські виробничі кооперативи, організаційно-облікове забезпечення, майно, капітали, паї, виплати, удосконалення, управління.

Summary. The article deals with laws and regulations, methodological recommendations and research, accounting forms, regulations and standards governing the formation and implementation of property and capital accounting in agricultural production cooperatives (APC). Their differences from the similar organization and accounting procedures in agricultural enterprises are established. In particular, it is about the lack of authorized capital and representation of its other types. The sources of the APC assets and capital formation and their mapping on the sub-accounts are also revealed. Much attention is paid to the formation of equity capital and various cooperative funds, as well as to the different kinds of payments and their accounting. The assessment of property and capital movement, payments and their accounting is made. The measures to improve their organizational and accounting support are developed.

Key words: agricultural production cooperatives, organizational and accounting support, property, capital, shares, payments, improvement, management.

\section{DOI : $10.33783 / 1977-4167-2019-46-2-134-138$}

Постановка проблеми. Діяльність сільськогосподарських виробничих кооперативів набуває дедалі більшого поширення у всьому світі. Використовуючи принципи кооперації, тобто добровільного об'єднання товаровиробників, вони сприяють розвитку аграрного виробництва, підприємницької ініціативи сільських жителів та формуванню середнього класу на селі. Тому вивчення діяльності кооперативів та розроблення іiі перспективних напрямів й удосконалення управління ними є актуальними та своєчасними.

Аналіз останніх досліджень і публікацій. Ідентифікація сутності, розроблення принципів, різні аспекти функціонування сільськогосподарських виробничих, обслуговуючих, а також споживчих кооперативів знайшли відображення у працях таких науковців, як: М. Гриценко, Л. Мармуль,
В. Плаксієнко та ін. Проте питання організаційно-облікового забезпечення формування майна та капіталів CBK, здійснення виплат і його удосконалення потребують подальших досліджень.

Мета статті - визначити систему, порядок, особливості організаційно-облікового забезпечення формування майна та капіталів сільськогосподарських виробничих кооперативів, відповідних виплат й обгрунтувати напрями його удосконалення.

Виклад основного матеріалу дослідження. Специфічною особливістю сільськогосподарських виробничих кооперативів (СBK) є те, що при створенні статутний капітал не формується, як це передбачено для господарських товариств. СВК у порядку, передбаченому його статутом, формує пайовий, резервний, неподільний та спеціальний (C) С. Ю. Кучеренко, Л. Ю. Леваєва, М. А. Кучеренко, 2019

Бібліографія ДСТУ 8302:2015:

Кучеренко С. Ю., Леваєва Л. Ю., Кучеренко М. А. Організаційно-облікове забезпечення майна та капіталів сільськогосподарських виробничих кооперативів. Вісник Бердянського університету менеджменту і бізнесу. 2019. № 2 (46). С. 134-138.

References (APA):

Kucherenko, S. Iu., Levaieva, L. Iu., Kucherenko, M. A. (2019). Orhanizatsiino-oblikove zabezpechennia maina ta kapitaliv silskohospodarskykh vyrobnychykh kooperatyviv [Organisational and accounting support of property and capitals of agricultural production cooperatives]. Visnyk Berdianskoho universytetu menedzhmentu i biznesu, 2 (46), 134-138 (in Ukr.). 
фонди (капітали) згідно зі ст. 20 Закону України «Про кооперацію» [1] (рис. 1).

Особливістю пайового капіталу є те, що його розмір не реєструється у статуті сільськогосподар- ського виробничого кооперативу, тому внески нових членів кооперативу чи вихід із членів кооперативу не потребують перереєстрації статуту в органах державної влади. У зв'язку з цим пайовий

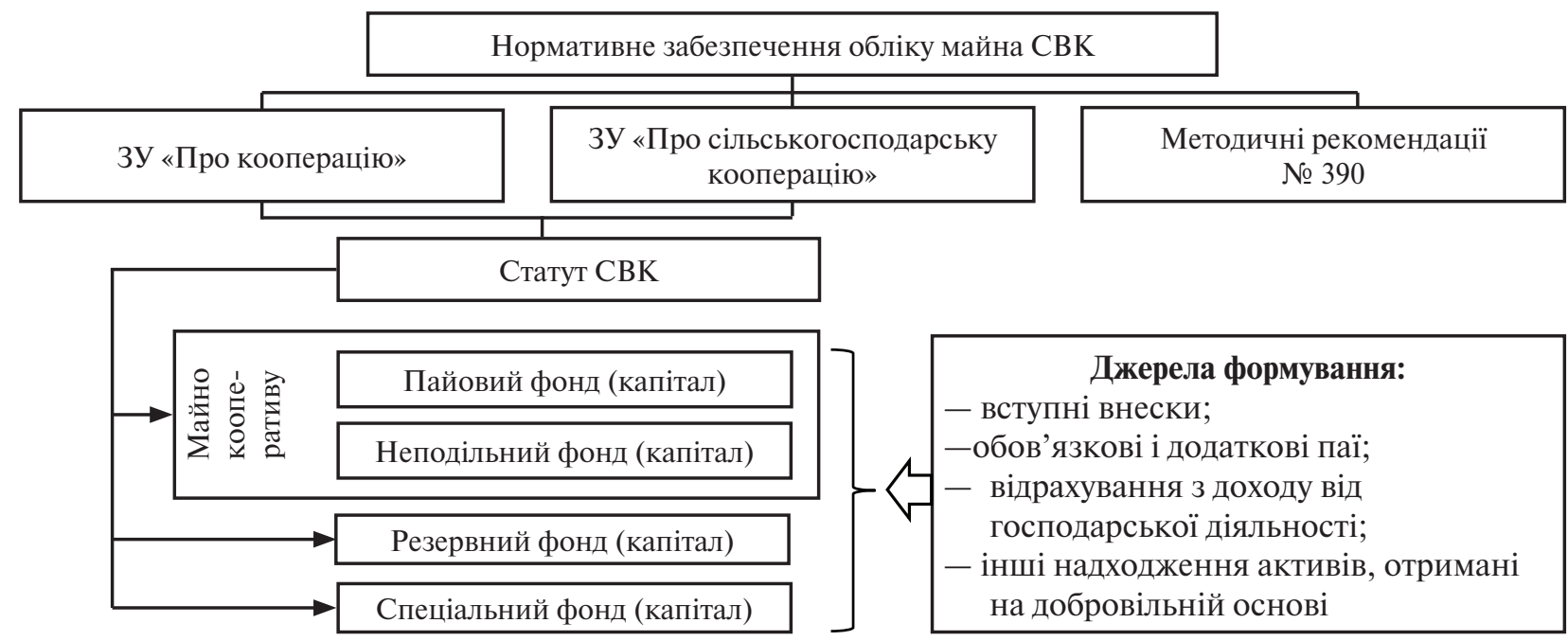

Рис. 1. Нормативно-облікове забезпечення майна та капіталів сільськогосподарського виробничого кооперативу

капітал формується в міру фактичної передачі пайовиками своїх внесків. Єдиної законодавчої бази формування і руху пайового капіталу не існує. А тому кожний кооператив під час вирішення таких питань керується нормами спеціального законодавства і власного статуту.

Джерелами формування майна сільськогосподарського виробничого кооперативу є: вступні, членські та цільові внески його членів, паї та додаткові паї; майно, добровільно передане кооперативу його членами; кошти, що надходять від провадження господарської діяльності. На підставі практичної діяльності СВК «Південний» (назва умовна) доцільно розглянути склад і джерела формування пайового капіталу:

- неподільний капітал формується зі вступних внесків учасників;

- основний пайовий капітал включає паї (майнові внески);

- додатковий пайовий капітал включає додаткові внески членів кооперативу за рахунок власних коштів); частки доходу на пай (дивіденди), інші внески.

Тому вважаємо за доцільне ведення обліку пайового капіталу за такими субрахунками:
- 4021 «Неподільний капітал»;

- 4022 «Основний пайовий капітал»;

- 4023 «Додатковий пайовий капітал».

На нашу думку, введення зазначених субрахунків підвищуватиме рівень інформаційного забезпечення прийняття управлінських рішень і розрахунків з членами кооперативу. Для цього використовуються джерела формування кожного 3 цих фондів (капіталів), субрахунки бухгалтерського обліку, на яких вони обліковуються (згідно з Методичними рекомендаціями № 190 [2]), з урахуванням змін, внесених наказом № 627 [3] до Плану рахунків бухгалтерського обліку та Інструкцій про його застосування, затверджених наказом № 291 [4]. Структуру власного капіталу СВК «Південний» характеризують показники, наведені в табл. 1.

Як свідчать дані табл. 1, найбільша питома вага у величині власного капіталу кооперативу «Південний» припадає на нерозподілений прибуток, який збільшився у 2017 р. на 1281,7 тис. грн або на 39,0 \% порівняно з попереднім роком. На пайовий капітал припадає лише 0,3-0,6 \% у динаміці за три останні роки та має тенденцію до зменшення, що пов'язано з виходом пайщиків 3 кооперативу. Загалом на власний капітал у паси-

Структура та динаміка власного капіталу

Таблиия 1

сільськогосподарського виробничого кооперативу «Південний» (назва умовна)

\begin{tabular}{|c|c|c|c|c|c|c|c|}
\hline \multirow{2}{*}{ Фонди (капітали) } & \multicolumn{2}{|c|}{$2015 \mathrm{p}}$. & \multicolumn{2}{|c|}{$2016 \mathrm{p}}$. & \multicolumn{2}{|c|}{2017 p. } & \multirow{2}{*}{$\begin{array}{c}2017 \text { р. у \% до } \\
2015 \text { p. }\end{array}$} \\
\hline & тис. грн & $\%$ & тис. грн & $\%$ & тис. грн & $\%$ & \\
\hline Зареєстрований (пайовий) капітал & 14,0 & 0,6 & 12,0 & 0,3 & 12 & 0,3 & 85,7 \\
\hline Додатковий капітал & 169,0 & 6,7 & 136,9 & 4,0 & 136,9 & 2,9 & 81 \\
\hline Нерозподілений прибуток (непокриті збитки) & 2342,0 & 92,7 & 3287,8 & 95,7 & 4569,5 & 96,8 & 195,1 \\
\hline Власний капітал, всього & 2525,0 & 100 & 3436,7 & 100 & 4718,4 & 100 & 186,9 \\
\hline
\end{tabular}


вах кооперативу припадає досить значна частка, яка щорічно зростає, зокрема у 2015 р. $-81,6 \%$, у 2016 p. $-88,8 \%$, а в 2017 p. $-90,8 \%$.

На відміну від інших фондів сільськогосподарських виробничих кооперативів, пайовий і не- подільний фонди існують протягом усього часу їх функціонування. У бухгалтерському обліку формування фондів сільгоспкооперативу за рахунок внесків його членів відображається у такий спосіб, наведений у табл. 2.

Таблиия 2 Формування фондів сільськогосподарського виробничого кооперативу «Південний» за рахунок внесків його членів

\begin{tabular}{|c|l|c|c|c|}
\hline \multirow{2}{*}{$\begin{array}{c}\text { № } \\
\text { 3/п }\end{array}$} & \multicolumn{2}{|c|}{ Зміст господарської операції } & \multicolumn{3}{|c|}{ Бухгалтерський облік } \\
\cline { 3 - 5 } & & 311 & Кредит & Сума, грн \\
\hline 1 & Надходження вступних внесків & 301 & 4021 & 10000 \\
\hline 2 & Надходження паю & 10 & 4022 & 30000 \\
\hline 3 & Надходження додаткового паю & 205 & 4023 & 20000 \\
\hline 4 & Отримання будівельних матеріалів & 422 & 40000 \\
\hline
\end{tabular}

Внески членів сільгоспкооперативу - пай, додатковий пай, вступні, членські, цільові внески, - є основними джерелами формування фондів (капіталів). Внески бувають як у грошовій, так і в майновій формі. Майнові внески оформляють первинними документами, прийнятими для операцій передачі відповідного майна, наприклад: необоротні матеріальні активи - актами приймання-передачі (внутрішнього переміщення) основних засобів (форма № ОЗСГ-1), запаси накладними (внутрішньогосподарського призначення) (форма №В3СГ-8) тощо.

Майно вноситься також на підставі акту приймання-передачі майна. В акті міститься опис майна, що вноситься, його грошова оцінка, дата, на яку майно вноситься до сільськогосподарського виробничого кооперативу, підпис члена кооперативу, що вносить таке майно, підпис голови кооперативу та печатка. Після передачі майна до коопе- ративу в його члена виникає право на пай - частку в майні кооперативу у вартісному вираженні.

Облік паїв членів сільськогосподарських виробничих кооперативів здійснюється в пайових книжках, пайових посвідченнях, картках пайовиків, інших документах, які засвідчують рух паїв, а також у реєстрах аналітичного та синтетичного обліку. Через таку невиправдану різноманітність форм обліку на практиці це призводить не лише до ускладнень і плутанини, а й до грубих помилок і порушень майнових прав членів кооперативу.

У бухгалтерському обліку сільськогосподарського виробничого кооперативу операції з формування резервного та неподільного фонду (капіталу) відображаються у спосіб, відображений у табл. 3. Особливістю обліку пайового капіталу є те, що зміни його розміру не призводять до перереєстрації кооперативу чи до внесення змін в установчі документи (табл. 3).

Облік операцій з формування резервного та неподільного фонду (капіталу) у сільськогосподарських виробничих кооперативах

\begin{tabular}{|c|c|c|c|c|}
\hline \multirow{2}{*}{$\begin{array}{l}\text { № } \\
\text { 3/ח }\end{array}$} & \multirow{2}{*}{ Зміст господарської операції } & \multicolumn{3}{|c|}{ Бухгалтерський облік } \\
\hline & & Дебет & Кредит & Сума, грн \\
\hline \multirow[t]{2}{*}{1} & $\begin{array}{l}\text { Направлено прибуток поточного року на формування: } \\
\text { резервного капіталу (фонду) }\end{array}$ & 443 & 43 & 2000 \\
\hline & неподільного капіталу (фонду) & & 4021 & 1000 \\
\hline 2 & $\begin{array}{l}\text { Отримано безповоротну фінансову допомогу на формування } \\
\text { резервного капіталу (фонду) }\end{array}$ & 311 & 43 & 5000 \\
\hline
\end{tabular}

Порядок відображення змін у розмірі пайового капіталу сільськогосподарського виробничого кооперативу наведено в табл. 4.

Бухгалтерський облік виплат у сільгоспкооперативах також має певні особливості. Так, у СВК «Південний» виплачують своїм членам: заробітну плату; кооперативні виплати; виплати на паї. Заробітну плату нараховують та виплачують у загальновстановленому порядку, прийнятому для заробітної плати, за формами та системами відповідно до норм чинного трудового законодавства.

Виплати на паї - виплати частини доходу кооперативу на паї члена кооперативу. Розмір виплат на паї встановлений рішенням загальних зборів після відрахувань обов'язкових коштів на формування й поповнення його фондів. Виплати здійснюють у грошовій формі, продукцією, а також у формі збільшення паю та інших формах, передбачених статутом кооперативу. Загальна сума виплат на паї не може перевищувати 20,0 \% доходу, визначеного до розподілу.

Загальна сума пайового капіталу, як вказувалося раніше, складається 3 обов'язкових i додаткових паїв членів сільгоспкооперативу та відображається у бухгалтерському обліку за кредитом субрахунку 4021. Водночас згідно із 
Таблиця 4

Кореспонденція рахунків з обліку руху пайового капіталу в сільськогосподарських виробничих кооперативах

\begin{tabular}{|c|c|c|c|}
\hline $\begin{array}{l}\text { № } \\
\text { 3/ח }\end{array}$ & Зміст & Дебет & Кредит \\
\hline \multicolumn{4}{|c|}{ Збільшення пайового капіталу СВК } \\
\hline 1 & $\begin{array}{l}\text { Внесені новими членами кооперативу грошові внески до неподільного } \\
\text { капіталу, а також обов'язковий і додатковий паї до складу пайового ка- } \\
\text { піталу }\end{array}$ & $\begin{array}{l}30,31,10,11,12 \\
14,15,16,20,28 \\
35\end{array}$ & $\begin{array}{l}4021,4022, \\
4023\end{array}$ \\
\hline 2 & Внесені додаткові паї членами СВК до складу його пайового капіталу & $\begin{array}{l}30,31,10,11,12 \\
14,15,16,20,28 \\
35\end{array}$ & 4022 \\
\hline 3 & $\begin{array}{l}\text { Збільшено розмір неподільного капіталу СВК за рахунок реінвестуван- } \\
\text { ня прибутку }\end{array}$ & 443 & 4021 \\
\hline 4 & $\begin{array}{l}\text { Направлено частину додаткового капіталу на збільшення пайового ка- } \\
\text { піталу СВК }\end{array}$ & 426 & 4022 \\
\hline \multicolumn{4}{|c|}{ Зменшення пайового капіталу СВК } \\
\hline 1 & $\begin{array}{l}\text { Зменшено розмір пайового капіталу за рахунок виходу члена із СВК: } \\
\text { - виділено частку в пайовому капіталі } \\
\text { - повернуто члену кооперативу його частку грошима }\end{array}$ & $\begin{array}{l}4022,4023 \\
672\end{array}$ & $\begin{array}{c}672 \\
30,31\end{array}$ \\
\hline 2 & $\begin{array}{l}\text { Направлено частину пайового капіталу СВК на покриття отриманих ко- } \\
\text { оперативом збитків }\end{array}$ & 4022 & 442 \\
\hline
\end{tabular}

Законом України «Про кооперацію» [1], розмір паю члена кооперативу залежить від фактичного його внеску до пайового капіталу. Паї, в тому числі резервного і спеціального фондів, $\mathrm{\epsilon}$ персоніфікованими й у сумі визначають загальну частку кожного члена кооперативу в майні кооперативу. Тобто, для підрахунку загального пайового капіталу та частки кожного члена сільгоспкооперативу слід брати також до уваги внески членів сільгоспкооперативу до резервного і спеціального капіталів.

Висновки. У процесі досліджень було виявлено, що здійснення обліку майна й капіталів сільськогосподарських виробничих кооперативів має суттєві відмінності від аналогічної роботи в аграрних підприємствах. Це пояснюється кооперативною природою СВК у частині формування майна і капіталів, а також здійснення виплат членам кооперативів. Перспективи удосконалення організаційно-облікового забезпечення полягають у посиленні достовірності аналітичного обліку, дотриманні своєчасності та здійсненні оцінювання й діагностики раціонального використання й зростання майна і капіталів.

\section{Література}

1. Про кооперацію: Закон України № 1087 XV від 04.08.2013 p. URL : http://zakon2.rada.gov. ua/laws/show/1087-15.

2. Методичні рекомендації щодо складання плану-графіка проведення документальних планових перевірок суб'єктів господарювання, затверджено Наказом Державної податкової адміністрації України від 01.04.2011 р. № 190. URL : http:// document.ua/pro-zatverdzhennja-metodichnihrekomendacii-shodo-skladannja-doc55698.html
3. Мних Є. В., Бутко А. Д., Большакова О. Д. та ін. Аналіз і контроль в системі управління капіталом підприємства : монографія. Київ : ВиД-во КНТЕУ, 2005. 232 с.

4. Корінець Р. Я., Малік М. Й., Масін В. М. та ін. Науково-практичний коментар до Закону України «Про сільськогосподарську кооперацію» та суміжних правових актів». Київ : ВАITE, 2014. $212 \mathrm{c}$.

5. Мармуль Л. О., Ігнатенко М. М., Леваєва Л. Ю., Романюк І. А. Ідентифікація на сільськогосподарських обслуговуючих кооперативів у сукупності форм організації діяльності селі. Агроcвim. 2019. № 17. С. 3-7.

6. Плаксієнко В. Я., Маренич Т. Г., Мармуль Л. О. Бухгалтерський облік у виробничих та агросервісних кооперативах. Київ: Центр учбової літератури, 2014. 448 с.

7. Marmul L. O., Ignatenko M. M., Ushakov D. S., Kuchyn S. P. Transformation of approaches to determine influence factors in the economic development models. International Journal of Economics \& Business Administration, vol. VII, iss. 2. 2019. pp. 290-301.

8. Ігнатенко М. М., Мармуль Л. О. Облік, оцінка й діагностика фінансово-економічних результатів діяльності у стратегічному менеджменті підприємств і організацій. Східна Европа: економі$\kappa a$, бізнес та управління. 2017. Вип. 6 (11). URL : http://www.easterneurope-ebm.in.ua/11-2017-ukr.

9. Романюк I. А. Особливості відтворювального процесу в аграрному секторі. Агросвіт. 2016. № 11. C. $12-15$.

10. Сільськогосподарські обслуговуючі кооперативи: створення і діяльність / ред. кол.: М. П. Гриценко (відп. ред.) та ін. Київ : Київська обласна аграрна дорадча служба, 2005. 68 с. 
11. Кучеренко М. А. Облік та аналіз виробничо-економічних показників діяльності сільськогосподарських кооперативів. Вісник Бердянського університету менеджменту $і$ бізнесу, 2018. № 4 (44). C. 44-48.

\section{References}

1. Verkhovna Rada of Ukraine (2013). About cooperation (The Law of Ukraine). Retrieved from http:// zakon2.rada.gov.ua/laws/show/1087-15 (in Ukr.).

2. State tax administration of Ukraine (2011). Metodychni rekomendatsii shchodo skladannia planuhrafika provedennia dokumentalnykh planovykh perevirok subiektiv hospodariuvannia, zatverdzheno Nakazom Derzhavnoi podatkovoi administratsii Ukrainy vid 01.04.2011 r. № 190 [Methodological recommendations for drawing up the schedule of documentary planned inspections of business entities, approved by the Order of the State Tax Administration of Ukraine from 01.04.2011. No. 190]. Retrieved from http://document. ua/pro-zatverdzhennja-metodichnih-rekomendaciishodo-skladannja-doc55698.html (in Ukr.).

3. Mnykh, Ye. V. \& oth. (2005). Analiz i kontrol $v$ systemi upravlinnia kapitalom pidpryiemstva [Analysis and control in the management of a capital company]. Kyiv, KNTEU (in Ukr.).

4. Korinez, R. Ya., Malik, M. Y., Masin, V. M. \& oth. (2014). Naukovo-praktychnyi komentar do Zakonu Ukrainy «Pro silskohospodarsku kooperatsiiu» ta sumizhnykh pravovykh aktiv».[Scientific-practical commentary to the Law of Ukraine «On agricultural cooperation» and related legal acts»]. Kyiv, WHITE, 212 p. (in Ukr.).

5. Ignatenko, N., Marmul, L., Levaieva, L., Romaniuk, I. (2019). Identyfikatsiia silskohospodarskykh obsluhovuiuchykh kooperatyviv u sukupnosti form orhanizatsii diialnosti na seli [Identification of agricultural service cooperatives in the aggregate forms of organization of activities in rural areas]. Ahrosvit, 17, 3-7 (in Ukr.).

6. Plaksiyenko, V. Ya. Marenych, T. H. and Marmul, L. O. (2014). Bukhhalterskyi oblik u vyrobnychykh ta ahroservisnykh kooperatyvakh [Accounting in production and agro-service cooperatives], Kyiv, Tsentr uchbovoyi literatury (in Ukr.).

7. Marmul, L. O., Ignatenko, M. M., Ushakov, D. S., Kuchyn S. P. (2019). Transformation of approaches to determine influence factors in the economic development models. International Journal of Economics \& Business Administration, vol. VII, iss. 2, 290-301 (in Eng.).

8. Ignatenko, N., Marmul, L. (2017). Oblik, otsinka y diahnostyka finansovo-ekonomichnykh rezul'tativ diyal'nosti u stratehichnomu menedzhmenti pidpryyemstv $i$ orhanizatsiy [Accounting, evaluation and diagnostics of financial and economic results of activity in strategic management of enterprises and organizations]. Skhidna Yevropa: ekonomika, biznes ta upravlinnya, 6 (11). Retrieved from http://www. easterneurope-ebm.in.ua/11-2017-ukr (in Ukr.).

9. Romanyuk, I. A. (2016). Osoblyvosti vidtvoryuvalnoho protsesu $v$ ahrarnomu sector [Features of thereproduction process in the agrarian sector]. Ahrosvit, 11, 12-15 (in Ukr.).

10. Hrytsenko, M. P. \& oth. (2005). Silskohospodarski obsluhovuiuchi kooperatyvy: stvorennia i diialnist [Agricultural service cooperatives: creation and activity]. Kyiv, Kyivska oblasna ahrarna doradcha sluzhba, 68 p. (in Ukr.).

11. Kucherenko, M. A. (2018). Oblik ta analiz. vyrobnycho-ekonomichnykh pokaznykiv diialnosti silskohospodarskykh kooperatyviv [Accounting and analysis of production and economic indicators of activity of agricultural cooperatives]. Visnyk Berdianskoho universytetu menedzhmentu $i$ biznesu, 4 (44), 44-48 (in Ukr.). 


\section{АННОТАЦИИ}

Кирова Л. Л. Перспективы развития мирового сельскохозяйственного рынка в современных мирохозяйственных условиях. - С. 9.

Аннотация. Рассмотрена и исследована роль мирового сельскохозяйственного рынка к вызову глобализации, его возможностей и перспектив.

Ключевые слова: сельскохозяйственное сырье, агропромышленные кластеры, агропродовольственный сектор, специализация, продовольствие, конкурентоспособность.

Маркина И. А., Калиниченко А. В., Лесюк В. С. Экономическое неравенство: мировой опыт и особенности в Украине. - С. 139.

Аннотация. Статья посвящена исследованию сущности и особенностей экономического неравенства в Украине и мире. Исследовано экономическое неравенство в Украине с помощью таких методов, как: кривая Лоренца, коэффициент Джини и квинтильный коэффициент. Рассмотрена динамика прожиточного минимума, номинальной и реальной заработной платы в Украине. Проанализирован уровень жизни и среднемесячная заработная плата в Украине и Европе. Определены основные направления реформирования социальной политики Украины для обеспечения устойчивого социального развития. Определены основные пути преодоления экономического неравенства в Украине.

Ключевые слова: экономическое неравенство, уровень жизни, заработная плата, кривая Лоренца, коэффициент Джини, квинтильный коэффициент.

Мармуль Л. А., Лаврега Г. Р. Приоритеты инвестиционного обеспечения устойчивого развития сельских территорий. - С. 19.

Аннотация. В статье выявлены проблемы дефицита финансирования и инвестирования, сохранения и устойчивого развития сельских территорий. Определены его причины и риски. Обоснованы новые источники и возможные ресурсы поступления инвестиций. Разработаны приоритетные направления их использования. Среди них первоочередное значение придано всесторонним инновациям. Обоснована определяющая роль государства в стимулировании и мотивациях инвестиционной деятельности крупного агробизнеса на селе.

Ключевые слова: сельские территории, финансирование, устойчивое развитие, инвестиционное обеспечение, приоритеты, инновации, конкурентоспособность, агробизнес, инфраструктура, управление.

Новак Н. П. Совершенствование институционального обеспечения привлечения иностранных инвестиций в экономику Украины. - С. 23.

Аннотация. В статье обоснована важность привлечения иностранных инвестиций в экономику Украины. Обнаружено, что эффективность и интенсивность этого процесса зависят от институционального обеспечения. Его составляюшие части определены как налоговые, финансовые, административные, нормативно правовые, ресурсно-функциональные. Установлены проблемы и определено направление развития отдельных институтов. Обоснованы приоритетные отрасли национальной экономики для привлечения иностранных инвестиций.

Ключевые слова: иностранные инвестиции, политика, привлечение, институциональная структура, национальная экономика, общественные отношения, направления.

Ортина Г. В., Леушина Е. А. Влияние государственной политики на инновационную деятельность устойчивого сбалансированного роста экономики в условиях глобализации. - С. 26.

Аннотация. В статье сделана попытка теоретически исследовать и практически обосновать пути совершенствования инвестиционной и инновационной политики страны в условиях глобализации. Выявлены негативные последствия неэффективной государственной политики, которая препятствует доверию к инвестиционной деятельности в национальную экономику. Отмечается, что устарела производственная база, изношенное оборудование мешает созданию новой государственной инновационно-инвестиционной политики страны. Отмечено, что современный этап развития требует от администрации не только содействия привлечению инвестиций из всех возможных источников, но и контроля за их целевым использованием, что позволяет активизировать производственные и технологические факторы экономического развития. В статье предложены пути повышения инвестиционной привлекательности страны.

Ключевые слова: инвестиции, новации, государственная политика, конкурентоспособность, образование, научно-технический прогресс, реальный сектор экономики. 
Трикоз И. В., Панчук С. С., Полохачев Л. П. Определение факторов влияния на гостиничную сферу Украины и особенности определения рисков функционирования. - С. 32.

Аннотация. В статье исследовано внешние и внутренние факторы влияния на развитие современных объектов размещения национальной гостиничной сферы. Определено, что гостиничный бизнес в рамках своих особенностей характеризуется наличием различных рисков. Определено, что от управления рисками функционирования гостиничного объекта напрямую зависит результат такого функционирования.

Ключевые слова: гостиничное хозяйство, гостиничная сфера, индустрия гостеприимства, риски.

Антошкин В. К., Кузьмин Е. В., Усатая Е. Н. Социально-экономическая безопасность в менеджменте субъектов на микроуровне. - С. 37.

Аннотация. В статье приводится обоснование методологических основ формирования и повышения социально-экономической безопасности аграрных предприятий и решения практических проблем управления ее обеспечением в их менеджменте современными механизмами, средствами и инструментами.

Ключевые слова: социально-экономическая безопасность, управление, менеджмент, ресурсы, предприятие, глобализационное пространство.

Беляев С. С. Преимущества проектного подхода на предприятии. - С. 41.

Аннотация. В статье рассмотрены сущность и специфические признаки развития предприятия с точки зрения проектного подхода. Приведены общие признаки проектов. Определены основные классы организаций, которые используют проектный подход. Раскрыта актуальность использования проектного подхода в управлении организацией.

Ключевые слова: предприятие, организация, проект, проектный подход, планирование, управление.

Бритвенко А. С., Запорожец Т. В., Смовж Т. С. Управление рисками как инструмент экономической безопасности масложировых компаний. - С. 45.

Аннотация. В статье рассмотрены основные направления инновационно-инвестиционной деятельности масложировых предприятий. Определены основные сегменты и способы производства. Приведена классификация предприятий масложирового подкомплекса в соответствии с типом продукции, которую они производят. Проанализированы основные тенденции инновационно-инвестиционной деятельности. Проиллюстрированы показатели объемов производства крупнейших продуцентов подсолнечного рафинированного и нерафинированного масел. Предложены пути решения проблем воспроизводства и обновления основных средств сельского хозяйства в условиях ограниченных финансовых возможностей сельскохозяйственных производителей и государственного бюджета.

Ключевые слова: инвестиции, инновации, маркетинг, масложировой подкомплекс, предприятие, сегментирование, пищевые растительные масла.

Гурбик Ю. Ю., Сальникова М. В. Теоретикометодологические основы антикризисного управления предприятием. - С. 51.

Аннотация. В статье осуществлен подробный и комплексный теоретико-методологический анализ антикризисного управления предприятием. Изучены подходы отечественных ученых относительно понимания и толкования сущности и содержания понятия «антикризисное управление предприятием». Охарактеризованы современные методы, которые используются в антикризисном управлении предприятия.

Ключевые слова: антикризисное управление предприятием, методы антикризисного управления, тактические методы антикризисного управления, стратегические методы антикризисного управления, антикризисное бизнес-планирование.

Игнатенко Н. Н. Проблемы и перспективы воссоздания производственно-ресурсного потенциала малых аграрных предприятий и домохозяйств населения. - С. 56.

Аннотация. В статье выявлены проблемы и тенденции использования и воспроизводства производственно-ресурсного потенциала агроформирований, особенно малых и средних, а также домохозяйств населения. Определено, что методологические преимущества обеспечения этих процессов имеют нормативный подход, что обеспечивает энергосбережение и ресурсосбережение. Обосновано влияние производственно-ресурсного потенциала и его рационального ресурсопользования на конкурентоспособность аграрных предприятий и домохозяйств населения. Определена необходимость совершенствования организационно-экономических механизмов управления развитием производственно-ресурсного потенциала с целью повышения эффективности его использования и обеспечения расширенного воспроизводства.

Ключевые слова: аграрные предприятия, домохозяйства, агрохолдинги, потенциал, проблемы, перспективы, воспроизводство, нормативные основы, управление, механизм, повышение, усовершенствование. 
Клименко А. А., Гуренко Х. Д., Качковский С. Ю. Влияние сроков сева и ширины междурядий на урожайность подсолнечника. - С. 61.

Аннотация. В статье рассмотрены результаты исследований по вопросам особенностей повышения экономической эффективности, развития и формирования урожаев подсолнечника, в зависимости от элементов технологии выращивания, срока сева и ширины междурядья. Приведена динамика урожайности культуры за последние три года. Проанализирована оптимальная площадь питания подсолнечника в условиях достаточного увлажнения. Приведена урожайность подсолнечника по категориям хозяйств.

Ключевые слова: подсолнечник, сроки сева, способы сева, гибриды, урожайность, производительность.

Пилявский В. И. Моделирование трудового потенциала агропромышленного предприятия. C. 67.

Аннотация. В статье рассмотрены особенности содержания, структуры, воспроизводства трудового потенциала агропромышленных предприятий и моделирование его развития. Выявлены основные составляющие и факторы использования трудовых ресурсов, его риски, проблемы и тенденции. Охарактеризованы этапы процесса моделирования трудового потенциала предприятий на перспективу. Обоснована важность форм его использования. Определена математическая модель воспроизводства трудового потенциала как некая системная процедура.

Ключевые слова: агропромышленные предприятия, трудовой потенциал, трудовые ресурсы, воспроизведение, моделирование, развитие, управление.

Романюк И. А. Формирование социальной направленности компаний сельского зеленого туризма и стратегии ее реализации. - C. 71.

Аннотация. В статье рассматриваются проблемы усиления социальной направленности деятельности туристических предприятий и предприятий сельского зеленого туризма в частности. Обоснована важность этого процесса и указаны его положительные последствия. Выявлены негативные факторы, которые препятствуют социологизации. Среди них недостаточная мотивация, финансовые проблемы, слабая государственная поддержка и др. Проанализирован зарубежный опыт, прежде всего европейский, социологизации предприятий отрасли. Осуществлена оценка эффективности деятельности социальных туристических предприятий в Украине и объяснено тенденции ее уменьшения. Выявлены резервы и предложены механизмы и инструменты усиления социальной направленности предприятий сельского зеленого туризма.
Ключевые слова: туристические предприятия, сельский зеленый туризм, социальная направленность, социальный менеджмент, маркетинг, стратегии, реализация, управление.

Рунчева Н. В., Горячая О. Л., Семенов К. А. Государственная поддержка экономической безопасности предприятий аграрного сектора. - С. 75.

Аннотация. В статье приведены результаты исследования по государственной поддержке экономической безопасности предприятий аграрного сектора. Приведены особенности регуляторного влияния государства на устойчивое развитие аграрных предприятий, обоснована система инструментов управления экономической безопасностью аграрных предприятий, динамические особенности их применения в зависимости от угроз внешней среды.

Ключевые слова: государственная поддержка, экономическая безопасность, аграрный сектор, агропредприятие.

Семененко А. Г., Горбатенко А. А. Совершенствование институциональных основ развития и повышения конкурентоспособности аграрных предприятий. - С. 80.

Аннотация. В статье рассмотрены проблемы и перспективы развития институционного обеспечения аграрных предприятий, в контексте их влияния на конкурентоспособность. При этом выявлены особенности и составляющие институционального обеспечения. В качестве узких мест указано на недостаточное развитие общественных организаций и профессиональных объединений в агросфере. Выявлены ментальные особенности населения, которые влияют на организацию институтов и конкурентоспособность аграрного производства. Это позволило обосновать концептуальные основы и определить направления и средства совершенствования институционального обеспечения аграрных предприятий с целью повышения их конкурентоспособности.

Ключевые слова: аграрные предприятия, институциональные основы, конкурентоспособность, обеспечение, повышение, ментальные особенности, общественные организации.

Соловьев Д. И., Голодаев В. С., Дейнега В. В. Заведения здорового питания как перспективный тренд развития ресторанного бизнеса. - C. 84 .

Аннотация. В статье исследованы современные мировые тенденции развития заведений здорового питания. Определена динамика потребностей граждан США и ЕС в здоровом питании и в заведениях здорового питания в 2012-2017 гг. Определены мировые лидеры развития заведений здорового питания. Определены ключевые про- 
блемы, с которыми сталкиваются соответствующие заведения при управлении ассортиментом услуг в условиях неблагоприятной конъюнктуры рынка.

Ключевые слова: общественное питание, слоуфуд, питание, заведения здорового питания.

Антошкина Л. И., Скворцова О. В. Демографические факторы формирования человеческого капитала Украины. - С. 89.

Аннотация. В статье проведен анализ основных демографических показателей формирования человеческого капитала. Проанализированы динамика и тенденции естественного воспроизводства населения. Определены основные причины ухудшения демографической ситуации в Украине и их негативное влияние на формирование человеческого капитала страны.

Ключевые слова: человеческий капитал, население, депопуляция, естественное движение, смертность, рождаемость.

Верба Д. В., Верховод И. С. Государственные расходы на образование и доступность образования для домашних хозяйств Украины. - С. 97.

Аннотация. Статья содержит апробацию аналитических приемов, предназначенных для оценки вклада бюджетных секторов социальных отраслей экономики в динамику благосостояния домохозяйств. В статье оценен вклад бюджетного сектора образования в благосостояние домохозяйств опосредованно: через динамику спроса на коммерческий сектор образования. Считая услуги коммерческого и бюджетного секторов образования плотно связанными в процессе удовлетворения потребностей домохозяйств, на примере Украины было исследовано отношение взаимозаменяемости и взаимодополняемости между благами, которые поставляют бюджетный и коммерческий секторы образования. Для этого была исследована функциональная связь между масштабами ресурсного обеспечения бюджетного сектора отрасли и спросом на блага (товары и услуги), которые поставляет ее коммерческий сектор.

Результаты моделирования эмпирически подтвердили способность ограничивать темпы роста цен на услуги образования, расширения ресурсного обеспечения коммерческого сектора и не обнаружили этого в расширении ресурсного обеспечения бюджетного сектора образования. Выявлены признаки того, что расширение ресурсного обеспечения бюджетного сектора образования сопровождается ростом давления на ресурсные возможности коммерческого сектора: наблюдается эффект вытеснения, известный в макроэкономике в отношении государственных и частных инвестиций.

Ключевые слова: социальные отрасли, образование, бюджетные расходы, доступность благ, коммерческий сектор, бюджетный сектор, масштабы потребления.

Попова Н. А., Княженко И. И., Кубрак И. С. Статистическое измерение сезонности труда в сельском хозяйстве. - С. 104.

Аннотация. В статье исследуются статистические методы измерения сезонных колебаний показателей использования трудовых ресурсов в сельском хозяйстве. Рассчитаны индексы сезонности и построены сезонные волны среднесписочной численности штатных работников, отработанного рабочего времени штатных работников, средней заработной платы в сельском хозяйстве. Определены пути уменьшения сезонных колебаний в сельском хозяйстве.

Ключевые слова: сезонные колебания, сезонная волна, индексы сезонности, занятость, трудовые ресурсы, сельское хозяйство.

Марченко О. А. Кластеризация как инновационное преимущество в функционировании и управлении региональной отраслью туризма. - C. 111.

Аннотация. В статье рассмотрены кластерные подходы как основное преимущество совершенствования механизмов функционирования и управления туристической индустрии на уровне страны и региона. Проанализированы составляющие кластерных механизмов управления, обоснован их инновационный характер. Предложен комплекс мер по созданию благоприятных условий развития туристических кластеров.

Ключевые слова: кластеризация; инновационные подходы; туристический кластер; туристическая отрасль; механизмы функционирования.

Фролова Г. И., Василатий Д. В., Миргородская Д. А. Стратегическое планирование в управлении экономическим развитием региона. - С. 116.

Аннотация. В статье раскрыты особенности стратегического управления экономическим развитием региона. Аргументировано влияние внутренних и внешних факторов на процесс стратегического планирования. Определены особенности стратегического планирования для обеспечения эффективного развития города Бердянска в период 2017-2020 гг.

Ключевые слова: регион, стратегическое управление, экономическое развитие региона, особенности организации стратегического управления, стратегия развития, стратегическое планирование, развития города, миссия города, стратегические и операционные цели развития города.

Малышко В. В. Направления и инструменты совершенствования финансовой политики в Украине. - С. 126. 
Аннотация. В статье обоснована важность совершенствования финансовой политики как основы любой социально и производственноэкономической деятельности. В качестве ее основных структурных компонентов определены бюджетно-налоговая, денежно-кредитная и политика управления государственным долгом; функциональных - управление финансовыми ресурсами и обеспечение бюджетной безопасности. Установлены экзогенные и эндогенные факторы, влияющие на эффективность осуществления финансовой политики и могут быть ее последствиями. Это государственный долг, бюджетный дефицит, нерациональные расходы финансовых ресурсов. Определены приоритетные направления и инструменты совершенствования финансовой политики, в т. ч. на уровне финансовых институтов.

Ключевые слова: управление, финансовая политика, бюджетная безопасность, государственный долг, дефицит, социально-экономические процессы, инструменты, экономический рост, приоритеты.

Коваль С. В. Организация и методика учета расчетных операций аграрных предприятий и направления их усовершенствования. - С. 130.

Аннотация. В статье выявлены особенности организации и осуществления учета расчетных операций аграрных предприятий. Выявлены их узкие места и источники возможных злоупотреблений. Указаны основные нормативные документы и международные и национальные стандарты обеспечения бухгалтерского учета. Осуществлена классификация расчетных операций, а также использование для их учета балансовых и внебалансовых счетов. Обосновано, что для совершенствования организации и учета расчетов и увеличение значимости их использования в управлении целесообразным является усиление достоверности аналитической составляющей учета. Для этого были разработаны направления практического решения указанной задачи.

Ключевые слова: аграрные предприятия, организация, учет, расчетные операции, в особенности, баланс, забалансовые счета, договоры, контракты, международные и национальные стандарты.

Кучеренко С. Ю., Леваева Л. Ю., Кучеренко М. А. Организационно-учетное обеспечение имущества и капиталов сельскохозяйственного производственного кооператива. - С. 134.

Аннотация. В статье рассмотрены нормативно-правовые акты, методические рекомендации и разработки, учетные формы, положения и стандарты, регламентирующие формирование и осуществление учета имущества и капиталов в сельскохозяйственных производственных кооперативах (СПК). Установлены их отличия от аналогичных процедур организации и учета в аграрных предприятиях. В частности, речь идет об отсутствии уставного капитала и представление его других видов. Также выявлены источники формирования имущества и капиталов СПК и их отражение на субсчетах в учете. Большое внимание уделено формированию паевого капитала и различных фондов кооперативов, а также различных видов выплат, порядка их осуществления и отражения в учете. Осуществлена оценка движения имущества, капиталов, а также осуществление выплат и их учета. Разработаны мероприятия по совершенствованию их организационно-учетного обеспечения.

Ключевые слова: сельскохозяйственные производственные кооперативы, организационноучетное обеспечение, имущество, капиталы, паи, выплаты, совершенствование, управление. 


\section{ВІДОМОСТІ ПРО АВТОРІВ}

Кірова Людмила Леонідівна, доцент кафедри економіки і фінансів Бердянського університету менеджменту і бізнесу, кандидат економічних наук, доцент.

71118, Запорізька обл., м. Бердянськ, вул. Свободи, 117-А.

Наукові інтереси: проблеми формування та розвиток сільськогосподарської кооперації.

Маркіна Ірина Анатоліївна, завідувач кафедри менеджменту, доктор економічних наук, професор, професор кафедри менеджменту Полтавської державної аграрної академії.

36000, Полтавська обл., м. Полтава, вул. Сковороди, $1 / 3$.

Наукові інтереси: менеджмент, економічна безпека, зовнішньоекономічна діяльність, маркетинг.

Калініченко Олександр Володимирович, кандидат економічних наук, доцент, доцент кафедри економіки та міжнародних економічних відносин Полтавської державної аграрної академії.

36000, Полтавська обл., м. Полтава, вул. Сковороди, $1 / 3$.

Наукові інтереси: національна економіка, економіка підприємства, інновації, енергоощадження, міжнародні економічні відносини.

Лесюк Владислав Станіславович, здобувач вищої освіти за ступенем «Магістр» 1 курсу освітньо-професійної програми «Менеджмент організацій» спеціальності «Менеджмент» факультету економіки та менеджменту Полтавської державної аграрної академії.

36000, Полтавська обл., м. Полтава, вул. Сковороди, $1 / 3$.

Наукові інтереси: менеджмент, економіка, фінанси, зовнішньоекономічна діяльність.

Мармуль Лариса Олександрівна, професор кафедри публічного управління та гуманітарних наук Національної академії керівних кадрів культури і мистецтв, доктор економічних наук, професор, Заслужений працівник освіти України.

02000, м. Київ, вул. Лаврська, 9.

Наукові інтереси: основні проблеми функціонування та розвитку соціальної інфраструктури сільських територій.
Новак Наталя Петрівна, доцент кафедри обліку і оподаткування Херсонського державного аграрного університету, доктор економічних наук.

73000, Херсон, вул. Стрітенська, 23.

Наукові інтереси: розвиток сільських теритоpій.

Ортіна Ганна Володимирівна, доктор наук з державного управління, доцент, завідувач кафедри публічного управління, адміністрування та права Таврійського державного агротехнологічного університету ім. Дмитра Моторного, orcid. org/0000-0003-0266-740X. ortinaganna@gmail.com.

72311, Запорізька обл., м. Мелітополь, пр. Б. Хмельницького 18. .

Наукові інтереси: економіка регіону, державне управління, гендерні дослідження, інвестиційна діяльність.

Леушина Олена Анатоліївна, кандидат економічних наук, доцент кафедри економіки та готельно-ресторанного бізнесу Мелітопольського державного педагогічного університету імені Богдана Хмельницького, orcid. 0000-0002-9504-174Х.

72319, Запорізька обл., м. Мелітополь, вул. Івана Алексєєва, д. 8-а, кв. 14.

Наукові інтереси: економіка регіону, інвестиційна діяльність.

Трикоз Ірина Володимирівна, старший викладач кафедри менеджменту і туризму Бердянського університету менеджменту і бізнесу.

71118, Запорізька обл., м. Бердянськ, вул. Свободи, 117-А.

Наукові інтереси: державно-приватне партнерство, інноваційний розвиток.

Антошкін Вадим Костянтинович, доцент кафедри обліку і фінансів Бердянського університету менеджменту і бізнесу, кандидат економічних наук, доцент.

71118, Запорізька обл., м. Бердянськ, вул. Свободи, 117-А.

Наукові інтереси: соціально-економічна безпека України.

Біляєв Серхій Серхійович, старший викладач кафедри економіки та готельно-ресторанного бізнесу Мелітопольського державного педагогічного університету імені Богдана Хмельницького, кандидат економічних наук. 
72319, Запорізька обл., м. Мелітополь, вул. Героїв України, б. 48, кв. 3.

Наукові інтереси: світова економіка, економіка зарубіжних країн, логістика, управління проєктами.

Бритвєнко Анастасія Сергї̈вна, доцент кафедри економіки і фінансів Бердянського університету менеджменту і бізнесу, кандидат економічних наук, доцент.

71118, Запорізька обл., м. Бердянськ, вул. Свободи, 117-А.

Наукові інтереси: економіка та управління аграрних та переробних підприємств.

Гурбик Юрій Юрійович, старший викладач кафедри економіки та готельно-ресторанного бізнесу Мелітопольського державного педагогічного університету імені Богдана Хмельницького, кандидат наук $з$ державного управління.

72319, Запорізька обл., м. Мелітополь, вул. Героїв України, б. 47, кв. 52.

Наукові інтереси: антикризове управління підприємством, державне регулювання рекреаційно-туристичної сфери, маркетингова діяльність підприємства.

Сальникова Марина Вікторівна, викладачстажист кафедри економіки та готельно-ресторанного бізнесу Мелітопольського державного педагогічного університету імені Богдана Хмельницького.

72319, Запорізька обл., м. Мелітополь, вул. Героїв України, б. 47, кв. 52.

Наукові інтереси: управління та організація бізнес-процесів на підприємстві, менчендайзинг в ресторанному господарсві.

Ігнатенко Микола Миколайович, завідувач кафедри економіки ДВНЗ «Переяслав-Хмельницький державний педагогічний університет імені Григорія Сковороди», доктор економічних наук, доцент.

08401, Київська обл., м. Переяслав-Хмельницький, вул. Сухомлинського, 30.

Наукові інтереси: фермерські господарства, дохідність, диверсифікація, сільський зелений туризм.

Клименко Анна Анатоліївна, доцент кафедри економіки і фінансів Бердянського університету менеджменту і бізнесу, кандидат економічних наук, доцент.

71118, Запорізька обл., м. Бердянськ, вул. Свободи, 117-А.

Наукові інтереси: економіка землекористування.
Пілявський Володимир Ілліч, докторант Міжнародного університету бізнесу і права (м. Херсон), кандидат економічних наук.

73039, м. Херсон, вул. 49-ї Херсонської Гвардійської дивізії, 37а.

Наукові інтереси: економічний потенціал агропромислових підприємств.

Романюк Ірина Анатолї̈вна, асистент кафедри економіки та маркетингу Харківського національного технічного університету сільського господарства ім. П. Василенка, кандидат економічних наук.

61000, м. Харків, просп. Московський, 45.

Наукові інтереси: сільське господарство, інтенсивний розвиток, туристичний ринок.

Рунчева Наталя Вікторівна, проректор 3 наукової роботи Бердянського університету менеджменту і бізнесу, доктор економічних наук, доцент.

71118, Запорізька обл., м. Бердянськ, вул. Свободи, 117-А.

Наукові інтереси: корпоративні відносини економіки аграрної сфери України.

Горяча Оксана Любомирівна, доцент кафедри економіки і фінансів Бердянського університету менеджменту і бізнесу, кандидат економічних наук, доцент.

71118, Запорізька обл., м. Бердянськ, вул. Свободи, 117-А.

Наукові інтереси: фінансові послуги, фінансові ринки, фінансові посередники, інвестиційна діяльність.

Семененко Олена Газисівна, старший викладач кафедри економіки ДВНЗ «Переяслав-Хмельницький ДПУ імені Григорія Сковороди».

08401, Київська обл., м. Переяслав-Хмельницький, вул Сухомлинського 30, ДПУ імені Григорія Сковороди,.

Наукові інтереси: економіко-математичне моделювання явищ та процесів в економіці, економічне оцінювання, оптимізація управління економічними системами.

Горбатенко Олена Анатолї̈вна, старший викладач кафедри економіки ДВНЗ «Переяслав-Хмельницький ДПУ імені Григорія Сковороди».

08400, Київська обл., м. Переяслав-Хмельницький, вул. Сухомлинського 30, ДПУ імені Григорія Сковороди, кафедра економіки.

Наукові інтереси: економіка підприємства, економіка і організація інноваційної діяльності, маркетинг. 
Соловйов Денис Ігорович, доцент кафедри менеджменту Бердянського університету менеджменту і бізнесу, кандидат економічних наук.

71118, Запорізька обл., м. Бердянськ, вул. Свободи, 117-А.

Наукові інтереси: державне регулювання туристичної сфери.

Антошкіна Лідія Іванівна, ректор Бердянського університету менеджменту і бізнесу, доктор економічних наук, професор.

71118, Запорізька обл., м. Бердянськ, вул. Свободи, 117-А.

Наукові інтереси: економіка вищої освіти, стратегічне управління підприємством.

Скворцова Ольга Вячеславівна, старший викладач кафедри менеджменту Бердянського університету менеджменту і бізнесу.

71118, Запорізька обл., м. Бердянськ, вул. Свободи, 117-А.

Наукові інтереси: використання і розвиток людського капіталу.

Попова Наталя Олександрівна, старший викладач кафедри економіки і фінансів Бердянського університету менеджменту і бізнесу.

71118, Запорізька обл., м. Бердянськ, вул. Свободи, 117-А.

Наукові інтереси: статистичні методи дослідження соціально-економічних явищ.

Княженко Ірина Іванівна, доцент кафедри менеджменту і туризму Бердянського університету менеджменту і бізнесу, кандидат економічних наук.

71118, Запорізька обл., м. Бердянськ, вул. Свободи, 117-А.

Наукові інтереси: державне регулювання економіки агропродовольчої системи України.

Марченко Оксана Анатоліївна, завідувачка кафедри економіки та готельно-ресторанного бізнесу Мелітопольського ДПУ імені Богдана Хмельницького, доктор економічних наук, доцент, відмінник освіти України.

72313, м. Мелітополь, вул. Брив-ла-Гайард 4, 49.

Наукові інтереси: економіка туризму.

Фролова Галина Іванівна, доцент кафедри менеджменту і туризму Бердянського університету менеджменту і бізнесу, кандидат економічних наук, доцент.

71118, Запорізька обл., м. Бердянськ, вул. Свободи, 117-А.

Наукові інтереси: інноваційно-інвестиційні фактори розвитку регіону.

Верховод Ірина Сергіївна, доцент кафедри економіки та готельно-ресторанного бізнесу Меліто- польського ДПУ імені Богдана Хмельницького, кандидат економічних наук, доцент.

72318, м. Мелітополь, Запорізька обл., бул. 30 років Перемоги, буд. 1, кв. 66.

Наукові інтереси: економіка праці, соціальна економіка і політика, фінансові відносини, регіональна економіка.

Верба Денис Володимирович, доцент кафедри економічної теорії ДВНЗ «КНЕУ імені Вадима Гетьмана», кандидат економічних наук, доцент.

72318, м. Мелітополь, Запорізька обл., бул. 30 років Перемоги, буд. 1, кв. 66.

Наукові інтереси: соціальна економіка, політика розподілу доходів в економіці України.

Малишко Віталіна Валерї̈вна, доцент кафедри фінансів, банківської справи і страхування ДВНЗ «Переяслав-Хмельницький ДПУ імені Григорія Сковороди», кандидат економічних наук.

08401, Київська обл., м. Переяслав-Хмельницький, вул. Сухомлинського, 30.

Наукові інтереси: державні фінанси України.

Коваль Світлана Вікторівна, доцент кафедри обліку і оподаткування Херсонського державного аграрного університету, кандидат економічних наук, доцент.

73006, м. Херсон, вул. Стрітенська, 23.

Наукові інтереси: облік у сільському господарстві.

Леваєва Людмила Юрї̈вн, доцент кафедри економіки ДВНЗ «Переяслав-Хмельницький ДПУ імені Григорія Сковороди», кандидат економічних наук, доцент.

08401, Київська обл., м. Переяслав-Хмельницький, вул. Сухомлинського, 30.

Наукові інтереси: основні проблеми забезпечення послугами соціальної інфраструктури населення сільських територій.

Кучеренко Микола Анатолійович, старший викладач кафедри обліку і оподаткування ДВНЗ «Переяслав-Хмельницький ДПУ імені Григорія Сковороди».

08401, Київська обл., м. Переяслав-Хмельницький, вул. Сухомлинського, 30.

Наукові інтереси: бухгалтерський облік і аналіз в аграрній сфері.

Кучеренко Свімлана Юрї̈вна, декан фінансово-гуманітарного факультету ДВНЗ «ПереяславХмельницький ДПУ імені Григорія Сковороди», кандидат економічних наук, доцент.

08401, Київська обл., м. Переяслав-Хмельницький, вул. Сухомлинського, 30.

Наукові інтереси: економічна теорія, аграрна економіка. 


\title{
BICHИК БЕРДЯНСЬКОГО УНІВЕРСИТЕТУ МЕНЕДЖМЕНТУ I БIЗНЕСУ
}

\author{
Випуск 2(46)'2019 \\ Науковий економічний журнал \\ Українською, російською та англійською мовами
}

Технічний редактор Д. В. Акіндєєв

Адреса редакції:

Україна, 71118, м. Бердянськ, вул. Свободи, 117-А

Тел. 8 (06153) 6-48-54

Підписано до друку 12.12.2019 p.

Формат 60x84/8. Папір офсетний.

Гарнітура «Newton C». Друк - лазерний.

Ум. друк. арк. 17,09. Обл.-вид. арк. 16,58.

Наклад 150 прим. Зам. № 0112.

Друк ТОВ «УСПІХ ПРИНТ»

69035, Запорізька обл., м. Запоріжжя, пр-т Соборний/вул. Південноукраїнська, дом $161 / 7$, оф. 12 